EMERSON SOARES MENDES

\title{
ANOTAÇÕES SOBRE O EXERCÍCIO DO PODER DE CONTROLE NAS COMPANHIAS COM CAPITAL DISPERSO
}

Dissertação de Mestrado

Orientador: Professor Associado Dr. Mauro Rodrigues Penteado

UNIVESIDADE DE SÃO PAULO

FACULDADE DE DIREITO

São Paulo - SP

2014 


\title{
ANOTAÇÕES SOBRE O EXERCÍCIO DO PODER DE CONTROLE NAS COMPANHIAS COM CAPITAL DISPERSO
}

\begin{abstract}
Dissertação de Mestrado apresentada à Banca Examinadora do Programa de Pós-Graduação em Direito, da Faculdade de Direito da Universidade de São Paulo, como exigência parcial para obtenção do título de Mestre em Direito, na área de concentração Direito Comercial, sob a orientação do Professor Associado Doutor Mauro Rodrigues Penteado.
\end{abstract}

\section{UNIVESIDADE DE SÃO PAULO}

FACULDADE DE DIREITO

São Paulo - SP 


\section{RESUMO}

Mendes, Emerson Soares. Anotações sobre o Exercício do Poder de Controle nas Companhias com Capital Disperso. 12/11/2014. 268 folhas. Mestrado - Faculdade de Direito, Universidade de São Paulo, São Paulo, 12/11/2014.

A presente dissertação possui como núcleo central o poder de controle e seu exercício nas companhias brasileiras de capital aberto, abordando algumas questões pontuais sobre o tema, sem a pretensão de esgotá-lo. Iniciando com um breve retrospecto histórico do modelo de sociedade por ações no âmbito mundial, passou-se a uma verificação da evolução histórico-legislativa das companhias no Brasil, culminando com suas principais características no âmbito do mais alto nível diferenciado de governança corporativa criado pela iniciativa da Bovespa. Após a introdução histórico-legislativa, este trabalho estudou o poder de controle nas sociedades empresárias, passando-se pela análise do conceito de poder de controle na Lei $n .^{\circ}$ 6.404/76, bem como pelo estudo de tal conceito no Direito Norte-americano, no Direito Comunitário Europeu, no Direito Francês e no Direito Inglês, para, então, verificar quais são os elementos essenciais para a caracterização do poder de controle no âmbito das sociedades por ações. Por fim, na última parte, verifica-se, segundo estudos consultados, se o modelo idealizado por Adolf Augustus Berle Jr. e Gardiner C. Means é aplicado efetivamente e se tal modelo seria um estágio máximo de evolução da sociedade por ações, com o atingimento de um alto grau de dispersão acionária, para, então, verificar a situação das companhias de capital aberto no Brasil, principalmente após a criação dos níveis diferenciados de governança corporativa pela iniciativa da Bovespa, terminando com a análise de estudos feitos sobre como o poder de controle é exercido nas companhias brasileiras de capital aberto e quais mecanismos são mais utilizados para a estabilização do poder de controle.

Palavras-chave: sociedade por ações - capital aberto - poder de controle - caracteres essenciais - exercício - mecanismos de estabilização. 


\section{RÉSUMÉ}

Mendes, Emerson Soares. Exposé sur l'Exercice du Pouvoir du Contrôle aux Compagnies avec Capital Dispersé. 12/11/2014. 268 feuilles. Maîtrise - Faculté de Droit, Université de São Paulo, São Paulo, 12/11/2014.

Cette dissertation a comme noyau centralle le pouvoir du contrôle e son exercice aux sociétés anonymes brésiliennes avec capital ouvert et traite des quelques questions déterminé sur le thème sans la prétention de le épuiser. On commence avec une concis restrospective historique sur le modèle de la société anonyme au monde, on a vérifié l'évolution historique et legislative de las compagnies au Brésil et culmine avec ses principales caractéristiques de le plus haut niveau différencié de le gouvernement d'enterprise créé par la iniciative de la Bovespa. Depuis l'introdution historique et legislative, cet travail a étudié le pouvoir du contrôle aux sociétés commerciales, on a analysé celui-là concept au Droit de les États-Unis, au Droit de la Communauté Européenne, au Droit Français et au Droit Anglais pour alors vérifier quels sont les éléments essentiels pour la caractérisation de le pouvoir du contrôle aux sociétés par actions. Au fin, à la dernière part, on a vérifié selon les études consultés si le modèle idéalisé par Adolf Augustus Berle Jr. et Gardiner C. Means est effectivement appliqué et si celui-là modèle serait un étage maximum de l'évolution de la société par action avec l'obtention du haut degré de dispersion actionnaire, alors pour vérifier la situation de las compagnies avec capital ouvert au Brésil, principalement depuis la création des niveaux différencies du gouvernement d'enterprise par la Bovespa, et on finit avec l'analyse des études sur comme le pouvoir du contrôle est exercé aux compagnies brésiliennes avec capital ouvert et quels sont les mécanismes plusier utilisé par le stabilisation du pouvoir du contrôle.

Mots-clé: société par actions - capital ouvert - pouvoir du contrôle - caractères essentiels - mécanismes de stabilisation. 


\section{FOLHA DE AVALIAÇÃO}

Nome: Mendes, Emerson Soares.

Título: Anotações sobre o Exercício do Poder de Controle das Companhias com Capital Disperso.

Dissertação apresentada à Faculdade de Direito da Universidade de São Paulo para a obtenção do título de Mestre em Direito Comercial.

Julgamento em:

\section{Banca Examinadora}

Prof. Dr.:

Instituição:

Julgamento:

Assinatura:

Prof. Dr.:

Instituição:

Julgamento:

Assinatura:

Prof. Dr.:

Instituição:

Julgamento:

Assinatura: 


\section{SUMÁRIO}

INTRODUÇÃO E NOÇÕES PRELIMINARES .................................................................7

PARTE I - COMPANHIAS: BREVE RETROSPECTO HISTÓRICO E AS VICISSITUDES ATUAIS DO MERCADO DE CAPITAIS ............................................21

1. ORIGEM E EVOLUÇÃO HISTÓRICA................................................................21

2. A SOCIEDADE POR AÇÕES NO BRASIL.......................................................83

2.1. EVOLUÇÃO HISTÓRICO-LEGISLATIVA DA COMPANHIA.........................83

2.2. A SOCIEDADE POR AÇÕES NO DIREITO SOCIETÁRIO BRASILEIRO...88

2.3. AS PRINCIPAIS CARACTERÍSTICAS DAS COMPANHIAS NO ÂMBITO DO NOVO MERCADO DA BM\&FBOVESPA .............................................................94

PARTE II - O PODER DE CONTROLE NAS SOCIEDADES POR AÇÕES...........100

3. O PODER DE CONTROLE NA SOCIEDADE EMPRESÁRIA .......................100

4. O PODER DE CONTROLE NA LEI N. ${ }^{\circ}$ 6.404/76 ...............................................112

5. O PODER DE CONTROLE NA DOUTRINA E LEGISLAÇÃO ESTRANGEIRAS ........................................................................................153

5.1. O DIREITO NORTE-AMERICANO....................................................................155

5.2. O DIREITO COMUNITÁRIO EUROPEU ……..............................................162

5.3. O DIREITO FRANCÊS .............................................................................173

5.4. O DIREITO INGLÊS..................................................................................180

6. OS ELEMENTOS ESSENCIAIS DO PODER DE CONTROLE........................190

PARTE III - OS SISTEMAS DE CAPITAL CONCENTRADO E DISPERSO E O EXERCÍCIO DO PODER DE CONTROLE NA COMPANHIA DE CAPITAL ABERTO BRASILEIRA.........................................................................................................198

7. OS SISTEMAS DE CAPITAL CONCENTRADO E DISPERSO......................198

8. REALIDADE BRASILEIRA: SISTEMA DE CAPITAL CONCENTRADO E DISPERSÃO ACIONÁRIA ..........................................................................................215

9. O EXERCÍCIO DO PODER DE CONTROLE NAS COMPANHIAS DE CAPITAL ABERTO NO BRASIL....................................................................................242 SÍNTESE CONCLUSIVA....................................................................................251

BIBLIOGRAFIA ........................................................................................................253 


\section{INTRODUÇÃO E NOÇÕES PRELIMINARES}

No início do Século XIX, ainda não havia, no Brasil, uma regulamentação acerca das sociedades anônimas, tampouco sistema, organizações e instrumentos adequados para proporcionar a circulação de capitais e de valores mobiliários em larga escala.

Com a vinda da Família Real ao Brasil, passaram a ser promulgadas normas esparsas e sintéticas sobre as sociedades por ações, sem uma regulamentação exaustiva, tal como a observada em legislações posteriores, como, por exemplo, a apresentada pelo Projeto de Miranda Valverde, que deu origem ao Decreto-lei n. ${ }^{\circ} 2.627 / 40$, o qual regulou minuciosamente as sociedades anônimas. Neste período o Brasil apresentava, ainda, um mercado de capitais pouco desenvolvido.

Somente a partir da segunda metade da década de 40 surgiu a primeira siderúrgica brasileira, tendo o Brasil apresentado, desde então, uma expansão industrial, introduzindo o Brasil em um período de transição para a industrializado em contraposição a sua característica extrativista que predominava até então.

Com o fim da Segunda Guerra Mundial, o desenvolvimento econômico foi a alavanca da restruturação das economias mundiais e, ainda, no Brasil ocorreu uma série de reformas legislativas com a finalidade de permitir um grande crescimento da poupança interna voltada para a atividade produtiva, o que levou o governo a promulgar desde meados da década de 1960 uma série de normas tendentes à criação de um mercado primário de ações.

Na década de 70, não obstante o esforço governamental em tentar criar um ambiente legal favorável ao desenvolvimento do mercado de capitais, este era, ainda, muito pouco desenvolvido. Nesta época, o Brasil apresentava o predomínio de sociedades anônimas familiares e de investidores de pequeno porte, o que levou o governo brasileiro a criar um mercado primário de ações, tendo, contudo, em 1971, ocorrido uma grave crise especulativa, coibindo o desenvolvimento do mercado primário. 
A Lei n. ${ }^{\circ}$ 6.404/76 foi concebida em um momento que o país não apresentava poupança interna, não obstante o momento de crescimento econômico, com o fim de permitir a realização de investimento pelo pequeno investidor, possibilitando ao empresário o acesso ao mercado de capitais para obtenção de financiamento da atividade produtiva a um custo menor que o financiamento bancário e, ainda, sem se socorrer do financiamento governamental.

$\mathrm{Na}$ época da promulgação da Lei n. ${ }^{\circ}$ 6.404/76 prevalecia os financiamentos bancário e estatal, época em que se tenta consolidar e efetivar as alterações promovidas desde 1964 voltadas ao fomento do mercado de capitais.

Na tentativa de dispersar o capital, em complemento à legislação já promulgada desde 1964, a Lei n. ${ }^{\circ}$ 6.404/76 expressamente reconhece a existência do poder de controle nas companhias, atribuindo-o ao acionista controlador. Surge, assim, a expressa referência às figuras do acionista controlador e do poder de controle na legislação brasileira.

Assim, a Lei n. ${ }^{\circ}$ 6.404/76 apresentou um fim de política pública, consistente no oferecimento mecanismos efetivos de financiamento privado de longo prazo, criando, dessa maneira, a sociedade anônima com acionista controlador (detentor do poder de controle) e acionistas investidores.

A Lei das Sociedades Anônimas em vigor trouxe, no art. $116^{1}$, um conceito de acionista controlador, do qual se extrai o conceito de poder de controle, que nada mais é que o poder atribuído, de modo estável, ao titular de direitos de sócio representativos da maioria de votos nas deliberações tomadas na assembleia geral, que, inclusive, permite-lhe

\footnotetext{
1 "Art. 116. Entende-se por acionista controlador a pessoa, natural ou jurídica, ou o grupo de pessoas vinculadas por acordo de voto, ou sob controle comum, que:

a) é titular de direitos de sócio que lhe assegurem, de modo permanente, a maioria dos votos nas deliberações da assembléia-geral e o poder de eleger a maioria dos administradores da companhia; $e$

b) usa efetivamente seu poder para dirigir as atividades sociais e orientar o funcionamento dos órgãos da companhia.

Parágrafo único. $O$ acionista controlador deve usar o poder com o fim de fazer a companhia realizar o seu objeto e cumprir sua função social, e tem deveres e responsabilidades para com os demais acionistas da empresa, os que nela trabalham e para com a comunidade em que atua, cujos direitos e interesses deve lealmente respeitar e atender." (BRASIL. Lei . $^{\circ}$ 6.404, de 15 d dezembro de 1976. Dispõe sobre as sociedades por ações. Disponível em <http://www.planalto.gov.br/ccivil_03/leis/16404consol.htm>. Acesso em: 02.11.2014)
} 
eleger a maioria dos administradores e, assim, dirigir as atividades da sociedade, incluindose a exploração dos bens organizados e destinados a tal fim social, bem como orientar o funcionamento de seus órgãos internos, ditando a política de atuação da sociedade com vistas a realizar o seu objeto social e, também, cumprir sua função social.

Todavia, até o ano 2000, praticamente, o Brasil não possuía mercado de capitais desenvolvido, além de apresentar um modelo de controle concentrado familiar.

Foi justamente com a criação dos chamados níveis de governança corporativa, pela então denominada Bovespa, que o mercado de capitais passou a apresentar um desenvolvimento mais significativo e implicou em um movimento de dispersão da participação acionária com a realização de diversas ofertas públicas iniciais (as famigeradas $I P O$ 's).

Assim, considerando a conjuntura da época em que foi elaborada a Lei $\mathrm{n}^{\circ}{ }^{\circ}$ 6.404/76, bem como a atual situação brasileira de incipiente e modesta dispersão da participação acionária, inexistente naquela época em que foi promulgada a retro referida lei, passou-se a questionar quais são os caracteres essenciais que caracterizam o acionista controlador, bem como a forma de seu exercício em companhias de capital aberto.

Desse modo, a presente dissertação pretende analisar os principais elementos do conceito de poder de controle e a forma em que o mesmo é exercido nas companhias brasileiras de capital aberto, levando-se em consideração, também, as disposições legais do direito estrangeiro, especialmente, mas não exclusivamente, nos países em que há dispersão de capital.

A fim de estudar alguns aspectos do conceito legal de poder de controle em confronto com a nova realidade brasileira de dispersão de capital, será demandado o estudo do sistema da Lei n. ${ }^{\circ} 6.404 / 76$.

Preliminarmente, o estudo versará sobre o tipo societário em questão, fazendo uma breve retrospectiva de sua evolução histórica até os dias atuais, conjugando o sistema da Lei das Sociedades Anônimas e o sistema das companhias listadas no Novo 
Mercado para se constatar as características principais da sociedade anônima em um ambiente de capital disperso.

Em seguida, passar-se-á à análise do conceito de poder de controle nas sociedades empresárias e nas sociedades anônimas, não só no direito brasileiro, mas também no direito estrangeiro, em especial no Direito Norte-americano, no Direito Comunitário Europeu, no Direito Francês e o Direito Inglês, visando pontuar os elementos essenciais do conceito de poder de controle.

Chegando-se aos elementos essenciais do conceito de poder de controle, o estudo pretende passar a uma análise do modelo do sistema de capital disperso e do modelo de companhia com capital disperso idealizada por Adolf Augustus Berle Jr. e Gardiner C. Means, de forma a permitir que se verifique se, como afirmado por Berle e Means, a dispersão acionária seria o caminho natural da evolução das sociedades por ações, bem como para permitir, após um breve retrospecto histórico-legislativo do mercado de capitais brasileiro e suas características, a verificação do exercício do poder de controle nas companhias brasileiras de capital aberto, especialmente após a criação dos níveis diferenciados de governança corporativa pela Bovespa.

A importância do poder de controle dentro das companhias já era conhecido antes mesmo da promulgação da Lei n. ${ }^{\circ}$ 6.404/76, como afirmou Fábio Konder Comparato:

“Ou seja, de toda a sistemática legislativa esta certamente ausente uma peça essencial para a compreensão do verdadeiro mecanismo de funcionamento das sociedades anônimas entre nós. Essa peça-mestra, segundo penso, é o poder de controle."2

Assim, encerra-se o trabalho com a apresentação de uma conclusão acerca do tema proposto.

${ }^{2}$ COMPARATO, Fábio Konder. Poder de Controle na Sociedade Anônima. In Revista de Direito Mercantil. São Paulo: Revista dos Tribunais, Ano XII, n. ${ }^{\circ}$ 9, 1973, p. 68. 
Em razão da equivocidade de alguns termos jurídicos, é preciso indicar, desde já, qual a acepção utilizada adiante no presente trabalho, para que sejam afastados equívocos interpretativos e, principalmente, para delimitar-se o uso do termo técnico equívoco.

Assim, o termo sistema, que é utilizado, no presente trabalho, associado às características existentes em dada localidade em que são predominantes as sociedades por ações de capital concentrado ou de capital disperso, tem a função primordial de estabelecer regularidades e regras, de modo que, segundo Lourival Vilanova ${ }^{3}$, seja formado um todo composto de partes dotadas de pertinencialidade, unidade e unicidade do ponto de partida.

Dessa maneira, em um sistema, há partes de um todo que apresentam vínculos que as interligam e as organizam, isto é, há elementos do todo que se relacionam formando um todo ordenado em função das semelhanças ou diferenças que as partes apresentam, formando, nas palavras de Mario Giuseppe Losano, “um corpus ordenado e coeso de conhecimentos científicos (como nos Diálogos sobre os dois máximos sistemas do mundo ptolomaico e copernicano, de Galileu Galilei), filosóficos (como no sistema kantiano), jurídicos (como sistema das fontes do direito, o sistema das obrigações, entre outros) e assim por diante."

Aplicando-se o termo sistema ao conjunto de companhias de capital aberto de dada localidade, temos que as companhias de capital aberto são o objeto da realidade que compõem o mercado de valores mobiliários, que é o sistema maior, cujos elementos componentes são unidos por um critério de unidade e com caráter orgânico e lógico, formando um todo coerente e harmônico ${ }^{5}$.

\footnotetext{
${ }^{3}$ VILANOVA, Lourival. As Estruturas Lógicas e o Sistema de Direito Positivo. 4. ${ }^{a}$ edição. São Paulo: Noeses, 2010, p. 127.

${ }^{4}$ LOSANO, Mario Giuseppe. Sistema e Estrutura no Direito: Das Origens à Escola Histórica. Vol. 1. São Paulo: Martins Fontes, 2008, p. XIX.

${ }_{5}^{5}$ A propósito, veja Geraldo Ataliba: "O caráter orgânico das realidades componentes do mundo que nos cerca e o caráter lógico do pensamento humano conduzem o homem a abordar as realidades que pretende estudar, sob critérios unitários, de alta utilidade científica e conveniência pedagógica, em tentativa do reconhecimento coerente e harmônico da composição de diversos elementos em um todo unitário, integrado em uma realidade maior. A esta composição de elementos, sob perspectiva unitária, se denomina sistema. Os elementos de um sistema não constituem o todo, com sua soma, como suas simples partes, mas desempenham cada um sua função coordenada com a função dos outros." (ATALIBA, Geraldo. Sistema Constitucional Tributário Brasileiro. São Paulo: Revista dos Tribunais, 1968, p. 4)
} 
Logo, ao se utilizar o termo sistema de capital concentrado e sistema de capital disperso, utilizou-se o termo sistema na acepção de conjunto de elementos relacionados entre si, apresentando pertinencialidade e unidade, formando um todo que apresenta unidade de ponto de partida, ou seja, parafraseando Rachel Sztjan ${ }^{6}$, o termo sistema foi utilizado enquanto conjunto de elementos que apresentam alguma relação e que são coordenados entre si, funcionando como uma estrutura organizada.

Ademais, deu-se preferência à referência ao Direito Societário e não ao Direito Empresarial no curso do presente trabalho, visto que o seu objetivo primordial reside no estudo dos elementos e caracteres do poder de controle nas companhias de capital aberto, o que, salvo melhor juízo, constitui objeto do Direito Societário, enquanto conjunto de normas jurídicas reguladoras das "relações entre as pessoas que se associaram para a realização de um fim comum”, abrangendo: “(i) a determinação da finalidade; (ii) a organização; (iii) a situação jurídica dos sócios (status socii); (iv) o ordenamento do patrimônio especial decorrente do nascimento da sociedade; e (iv) o ordenamento da empresa." 7

Assim, como o estudo visa a analisar o poder de controle e seus elementos dentro da sociedade por ações de capital aberto e não a empresa como fato humano econômico voluntário ${ }^{8}$ consistente na atividade econômica organizada, entendemos ser mais adequado fazer referência ao Direito Societário, enquanto direito das sociedades empresárias, e não ao Direito Empresarial, enquanto direito da empresa na qualidade de fato humano econômico voluntário, que, por sua vez, torna-se fato jurígeno ao corporificar-se, no âmbito jurídico, por meio da celebração de um contrato de sociedade, como bem apontou Pontes de Miranda:

\footnotetext{
${ }^{6}$ SZTAJN, Rachel. Sistema Financeiro Entre Estabilidade e Risco. Rio de Janeiro: Elsevier, 2011, p. 45.

7 VERÇOSA, Haroldo Malheiros Duclerc. Curso de Direito Comercial. Vol. 2. 2. ${ }^{a}$ edição. São Paulo: Malheiros, 2010, p. 32.

${ }^{8}$ Veja Maria Helena Diniz: “O fato humano é o acontecimento que depende da vontade humana, abrangendo tanto os atos lícitos como os ilícitos. Pode ser: a) voluntário, se produzir efeitos jurídicos queridos pelo agente, caso em que se tem o ato jurídico em sentido amplo, que abrange: o ato jurídico em sentido estrito, se objetivar a mera realização da vontade do agente (perdão, ocupação, confissão etc.) e o negócio jurídico, se procura criar normas para regular interesses das partes, harmonizando vontades que, na aparência, parecem antagônicas (testamento, contratos, adoção etc.) e que se subordinam a algumas disposições comuns". (DINIZ, Maria Helena. Curso de Direito Civil Brasileiro: Teoria Geral do Direito Civil. $1 .^{\circ}$ vol.

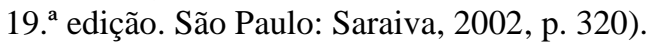


"O mundo jurídico confina com o mundo dos fatos (materiais, ou enérgicos, econômicos, políticos, de costumes, morais, artísticos, religiosos, científicos), donde as múltiplas interferências de um no outro. O mundo jurídico não é mais do que o mundo dos fatos jurídicos, isto é, daqueles suportes fáticos que logram entrar no mundo jurídico. A soma, tecido ou aglomerado de suportes fáticos que passaram à dimensão jurídica, ao jurídico, é o mundo jurídico. Nem todos os fatos jurídicos são idênticos. Donde o problema inicial de os distinguir e de os classificar.

2. Entrada no mundo jurídico. O fato jurídico provém do mundo fático, porém nem tudo que o compunha entra, sempre, no mundo jurídico." 9

Há que se ressaltar, ainda, que o Direito Societário, embora tenha origem no fato humano econômico voluntário, que é a empresa enquanto atividade econômica organizada, não se limita ao estudo daquele fato, mas, sim, suplanta-o ${ }^{10}$, o que reforça nosso entendimento de que mais adequada é a referência ao Direito Societário em detrimento do Direito Empresarial.

Acrescente-se, também, que, embora o presente trabalho tenha como foco o estudo dos elementos do poder de controle no âmbito das sociedades por ações de capital aberto, preliminarmente analisou-se o poder de controle no âmbito das sociedades empresárias enquanto gênero do qual as companhias de capital aberto constituem espécie, para, então, estudar-se o poder de controle no âmbito das companhias de capital aberto.

Desde já, faz-se necessário ressaltar que, embora os arts. $1 .^{\circ}$ e $3 .^{\circ}$, caput, da Lei n. ${ }^{\circ} 6.404 / 76^{11}$ indique o uso das denominações sociedade anônima e companhia, após a

\footnotetext{
${ }^{9}$ MIRANDA, Pontes de. Tratado de Direito Privado. Tomo 2. Campinas: Bookseller, 2000, p. 221.

${ }^{10}$ Veja, a propósito, Miguel Reale: "Devemos entender, pois, que o Direito se origina do fato, porque, sem que haja um acontecimento ou evento, não há base para que se estabeleça um vínculo de significação jurídica. Isto, porém, não implica a redução do Direito ao fato, tampouco em pensar que o fato seja mero fato bruto, pois os fatos, dos quais se origina o Direito, são fatos humanos ou fatos naturais objet de valorações humanas." (REALE, Miguel. Lições Preliminares de Direito. 20. a edição. São Paulo: Saraiva, 1993, p. 198)

11 "Art. $1^{\circ}$ A companhia ou sociedade anônima terá o capital dividido em ações, e a responsabilidade dos sócios ou acionistas será limitada ao preço de emissão das ações subscritas ou adquiridas." (BRASIL. Lei n. ${ }^{\circ}$ 6.404, de 15 d dezembro de 1976. Dispõe sobre as sociedades por ações. Disponível em <http://www.planalto.gov.br/ccivil_03/leis/16404consol.htm>. Acesso em: 02.11.2014)
} 
proibição da emissão de ações ao portador pelos arts. $1^{\circ}{ }^{o}$, caput, e $4 .^{\circ}$, da Lei n. ${ }^{\circ} 8.021 / 90^{12}$, perdeu sentido a denominação sociedade anônima, visto que justamente o anonimato dos acionistas passou a ser proibido, desde à época do lançamento do Plano Collor I.

Assim, tecnicamente, seria mais correto deixar de fazer referência às sociedades anônimas para que fossem utilizadas as denominações companhia ou sociedade por ações. Contudo, no presente trabalho serão utilizadas indistintamente as denominações sociedade por ações, companhias e sociedades anônimas como expressões sinônimas, sendo que esta última expressão, em razão do uso consagrado, será também utilizada no presente trabalho, embora não seja a mais adequada tecnicamente.

Preliminarmente, ainda, é preciso que sejam feitas algumas observações introdutórias ao estudo que se pretende desenvolver por meio desta dissertação.

Para o estudo do exercício do poder de controle no âmbito das companhias de capital aberto, é fundamental ter-se uma sucinta noção dos fundamentos do processo econômico e, consequentemente, dos fundamentos do mercado, como forma, inclusive, de esclarecer o funcionamento da empresa no âmbito da atividade econômica e também de sua organização jurídica por meio do instituto jurídico da sociedade empresarial.

Toda a atividade de uma dada comunidade depende de uma certa estabilidade estrutural para que se desenvolva, o que não impede que o Direito desta comunidade seja modificado no decurso do tempo. As mudanças quantitativas e qualitativas do Direito dependem, por sua vez, da dinâmica social que determinará a evolução e adaptação das normas jurídicas à realidade social vigente.

Contudo, na vida comunitária, há situações conjunturais que se mostram incompatíveis com a estabilidade estrutural, mas que também são consideradas integrantes

"Art. $3^{\circ}$ A sociedade será designada por denominação acompanhada das expressões "companhia" ou "sociedade anônima", expressas por extenso ou abreviadamente mas vedada a utilização da primeira ao final." (BRASIL. Lei n. ${ }^{\circ}$ 6.404, de 15 d dezembro de 1976. Dispõe sobre as sociedades por ações. Disponível em <http://www.planalto.gov.br/ccivil_03/leis/16404consol.htm>. Acesso em: 02.11.2014)

12 "Art. $1^{\circ}$ A partir da vigência desta lei, fica vedado o pagamento ou resgate de qualquer título ou aplicação, bem como dos seus rendimentos ou ganhos, a beneficiário não identificado."

“Art. $4^{\circ} \mathrm{O}$ art. 20 da Lei $n^{\circ}$ 6.404, de 15 de dezembro de 1976, passa a vigorar com a seguinte redação:

"Art. 20. As ações devem ser nominativas."'" (BRASIL. Lei n. ${ }^{\circ} 8.021$, de 12 de abril de 1990. Dispõe sobre a identificação dos contribuintes para fins fiscais e dá outras providências. Disponível em < http://www.planalto.gov.br/ccivil_03/leis/L8021.htm>. Acesso em 02.11.2014) 
da estrutura social. Segundo Geraldo de Camargo Vidigal, os imperativos conjunturais são aqueles "que resultam de forças que determinam flutuações ambientais de curto prazo, não compatíveis com a rigidez de um quadro estrutural." ${ }^{\prime 13}$ Desse modo, entre a estrutura estável e os imperativos conjunturais, há uma interação que acaba por influenciar o comportamento dos seres de dada comunidade.

Ainda, segundo Geraldo de Camargo Vidigal, uma estrutura sócio-cultural é constituída dos seguintes elementos essenciais: (a) conjunto de recursos naturais; (b) conjunto de equipamentos produtivos; e (c) conjunto de estoque de bens de consumo.

Os recursos naturais, quando insertos em uma relação humana, constituem um elemento estável, mas passível de modificações em virtude da exploração humana e das forças da natureza. Os equipamentos produtivos, enquanto o conjunto de bens de capital, por sua vez, devem ser constantemente produzidos com a finalidade de substituir aqueles que se desgastam com o uso constante na atividade econômica produtiva, servindo não só à produção para satisfazer o crescimento da demanda, mas também para fazer frente às necessidades decorrentes do esgotamento dos recursos naturais.

Diante do constante crescimento demográfico, há a necessidade de serem feitos mais aportes de capital, como forma de restabelecer a relação capital per capita, permitindo, assim, o crescimento da riqueza, da produção e das rendas sociais, uma vez que o capital per se é muito estável quantitativa e qualitativamente.

Em relação aos bens de consumo, quando se tratar de bem de consumo único ou não durável, o mesmo deve ser reposto à medida que é efetivamente consumido, enquanto que aos bens de consumo duráveis deve ser dado o mesmo tratamento dos bens de capital, ou seja, devem ser repostos à medida que se desgastam com o uso constante.

Assim, os homens de uma dada comunidade, ao interagirem, vão modificando seus relacionamentos com o ambiente em que vivem, seja em relação aos recursos naturais, seja em relação aos equipamentos produtivos ou, ainda, em relação aos bens de consumo, simplesmente porque os seres humanos vão alterando-se quantitativa e

${ }^{13}$ VIDIGAL, Geraldo de Camargo. Fundamentos do Direito Financeiro. São Paulo: Revista dos Tribunais, 1973, p. 101. 
qualitativamente no decurso do tempo, de modo que apresentam uma acumulação do aprimoramento que é transmitido às novas gerações. Justamente a transmissão do aprimoramento acumulado no decorrer dos anos proporciona um avanço tecnológico e do próprio capital, o que, por sua vez, acaba causando uma expansão dos mercados.

Este processo de desenvolvimento tecnológico, que é viabilizado pela acumulação e transmissão do aperfeiçoamento humano, proporciona uma maior especialização da mão de obra e, portanto, desencadeia uma divisão do trabalho mais aprimorada, que alavanca o crescimento da produtividade de cada trabalhador. Obviamente que este processo de aperfeiçoamento tecnológico desenvolve-se paulatinamente.

Conforme ensina Geraldo de Camargo Vidigal, o Direito constitui uma das técnicas dominadas pelo homem, o qual se destina a disciplinar os atos e interesses dentro de uma dinâmica social, in verbis:

"Dentre as técnicas dominadas pelo Homem, destacam-se singularmente as do Direito, técnica da própria convivência social.

Para que as relações entre os homens possam desenvolver-se ordenadamente, é necessário que a tutela dos interesses e a disciplina dos atos se exerçam com estabilidade, preservada a dinâmica da vida social. A Dogmática, assim, compõe um quadro vivo, mas relativamente estável." 14

Dessa forma, dentro de uma estrutura social, assim considerada como sendo um conjunto de relações de interação de diversos elementos proporcionalmente estáveis, o Direito está inserido dotado de certa estabilidade, ou seja, na estrutura social, o Direito apresenta-se como um elemento estável, mas dotado de certa dinâmica (em razão de suas alterações paulatinas em consequência da dinâmica da sociedade), em um ambiente social em que o grupo social estável, por meio de técnicas estáveis e com o uso de equipamentos que são alterados gradativamente, explora um mundo físico dotado de estabilidade.

${ }^{14}$ VIDIGAL, Geraldo de Camargo. Fundamentos do Direito Financeiro. São Paulo: Revista dos Tribunais, 1973, p. 105. 
Mas, nesta estrutura social, há ocorrências dinâmicas que causam mudanças bruscas, além de não apresentarem proporcionalidade dentre seus elementos. Estas ocorrências dinâmicas são as conjunturas que são definidas "como um jogo de dinâmicas relações de interação entre elementos em proporções irregularmente oscilantes." "15

No que concerne ao processo econômico, a economia, ao incorporar mecanismos financeiros, acaba por inserir a conjuntura rotineiramente, deixando, por isso, de ser, a conjuntura, um elemento excepcional no âmbito econômico. Isto ocorre porque o elemento financeiro da economia imputa-lhe elementos conjunturais que lhe são ínsitos e, simultaneamente, retira-lhe a estabilidade.

A atividade econômica (ou processo econômico na denominação utilizada por Geraldo de Camargo Vidigal), por sua vez, enquanto esforço social produtivo, consiste na aplicação do trabalho nos recursos naturais disponíveis por meio da utilização dos equipamentos produtivos existentes, cujo resultado pode ser analisado sob duas óticas: sob a ótica da expressão física e sob a ótica da expressão monetária.

Sob a ótica da expressão física, o resultado da aplicação do trabalho social sobre os recursos da natureza (isto é, sobre a riqueza existente), com a utilização dos equipamentos produtivos existentes, consistirá no conjunto de bens e/ou serviços (denominados de produtos sociais) que serão colocados no mercado. Estes produtos ou serviços, também denominados de produto social ou físico, são compostos por um subconjunto de bens e serviços de consumo e um subconjunto de bens de capital (que são aqueles bens de produção) e de investimento (que são aos investimentos feitos em capital físico).

Já sob a ótica da expressão monetária, o resultado decorrente da aplicação do trabalho social sobre a riqueza existente, com o uso de equipamentos produtivos, consistirá na renda social, que nada mais é que o conjunto de remunerações de fator, ou seja, a remuneração percebida em moeda e proporcional ao aporte efetuado no esforço coletivo empenhado no processo econômico, podendo ser o salário pago aos trabalhadores, os juros dos capitais e os lucros ou prejuízos sofridos pelos empresários.

${ }^{15}$ VIDIGAL, Geraldo de Camargo. Fundamentos do Direito Financeiro. São Paulo: Revista dos Tribunais, 1973, p. 106. 
Comparando o produto social com a renda social, o primeiro denota uma situação dotada da estabilidade, enquanto que a segunda contempla uma situação dinâmica, justamente por envolver um fluxo, isto é, uma parcela da renda social é destinada aos gastos de consumo e outra parcela é destinada à constituição da poupança. Enquanto o conjunto de bens e serviços de consumo resultante do trabalho social é dinamicamente igual aos gastos de consumo, a parcela da renda social destinada à constituição da poupança não guarda igualdade dinâmica aos investimentos, pois os investidores nunca utilizam o mesmo montante de sua poupança nos investimentos, além de, geralmente, utilizarem crédito concedido para que realizem os investimentos, o qual supera em muito a capacidade dos investidores pouparem.

Deve-se observar que a poupança somente gera riqueza quando, sendo os gastos de consumo inferiores à renda social, a parcela destinada à poupança for efetivamente investida pelo poupador, visto que o meio de circulação da riqueza - que é a moeda - não é riqueza, enquanto que, para a empresa, ela será capitalizada quando distribuir dividendos inferiores aos lucros realizados, de modo que o excedente de lucro enriquecerá diretamente a empresa ao haver a transferência interna deste montante (excedente a título de lucro) à atividade produtiva.

Como observado por Geraldo de Camargo Vidigal, "a grande maioria dos que realizam poupanças não possui disposição empresarial e não faz investimentos" ${ }^{\prime 16}$, o que evidencia a inexistência de relação entre as decisões de investir e as decisões de poupar. Assim, enquanto o consumo gera renda social, que, por sua vez, é a origem da poupança, os "investimentos surgirão do peculiar conjunto de qualidades que compõem a disposição empresarial, quando confrontado com a expectativa de que dos investimentos advirão lucros, a um percentual excedente da taxa de juros do mercado."

Assim, embora haja uma diversidade entre a poupança e o investimento planejados, quando da concretização do investimento, há a utilização de mecanismos de acomodação entre poupança e investimentos, que são formados pelos fenômenos da moeda

\footnotetext{
${ }^{16}$ VIDIGAL, Geraldo de Camargo. Fundamentos do Direito Financeiro. São Paulo: Revista dos Tribunais, 1973, p. 112.

${ }^{17}$ Idem, ibidem, p. 113.
} 
e do crédito, ou seja, esta acomodação entre poupança e investimentos ocorre por meio de processos monetários que são diretamente influenciados pelas finanças públicas.

Logo, as sociedades por ações devem ser estudadas levando-se em conta os fundamentos do mercado acima indicados, isto porque, como bem indicou Rafael Perez Escolar $^{18}$, as companhias mobilizam uma grande quantidade de capitais no exercício de sua atividade econômica, seja para fazer frente à necessidade de atender à demanda e, assim, apresentar um processo produtivo acelerado, seja para captar recursos a serem destinados à execução de novos projetos econômicos, sem prejuízo da necessidade de oferecer retorno as investimentos feitos pelos acionistas, motivo pelo qual se pode considerar que a sociedade por ações constitui um verdadeiro instrumento técnico-jurídico do capitalismo.

Isto porque, ao mobilizar uma grande quantidade de capital com a finalidade de aperfeiçoar a técnica produtiva, a companhia proporciona um estímulo ao progresso técnico, justamente em busca da redução dos custos da produção e do aumento de sua produção para satisfazer a demanda, o que acaba por facilitar as trocas, o que somente é possibilitado pelo investimento.

E a importância da sociedade por ações, enquanto instrumento típico do capitalismo, é tão grande que seu funcionamento interessa a toda uma nação, pois, segundo André Tunc ${ }^{19},(\boldsymbol{a})$ as companhias exercem uma influência na economia nacional a partir do momento em que a bolsa de valores acaba por refletir uma opinião do mercado sobre o futuro da economia nacional e, ainda, (b) o sistema capitalista deve proporcionar vigor e honestidade para estimular o investidos a aportar recursos por meio de valores mobiliários,

\footnotetext{
18 “Este ligero bosquejo histórico nos muestra que la sociedad por acciones o sociedad anónima (28) surge como instrumento técnico-jurídico del capitalismo. Las grandes empresas de ultramar exigen la movilización de ingentes cantidades de dinero; los nuevos proyectos económicos han de ser realizados por la acumulación de muchas fortunas individuales. Exigencias todas que se cumplen mediante este tipo de ente social. Pero no sólo las sociedades anónimas posibilitan la conquista económica y una acelerada productividad (29), sino que también hacen real el enriquecimiento de titulares de pequeñas fortunas (30)." (Tradução livre: "Este ligeiro esboço histórico mostra-nos que a sociedade por ações ou sociedade anônima (28) surge como instrumento técnico-jurídico do capitalismo. As grandes empresas ultramarinas exigem a mobilização de grande quantidade de dinheiro; os novos projetos econômicos devem ser realizados pela acumulação de muitas fortunas individuais. Todas estas exigência cumprem-se por meio deste tipo de ente social. Mas não apenas as sociedades anônimas possibilitam a conquista econômica e uma acelerada produtividade (29), senão que também tornam real o enriquecimento dos titulares de pequenas fortunas (30).”) (ESCOLAR, Rafael Perez. La Sociedad Anónima Europea. Madrid: Montecorvo, 1972, p. 90)

${ }^{19}$ TUNC, André. Le Droit Anglais Des Sociétés Anonymes. 2 édition. Paris : Dalloz, 1978, p. 1.
} 
denotando sua alta influência no sistema econômico, do que decorre a importância também do poder de controle das companhias. 


\section{PARTE I}

\section{COMPANHIAS: BREVE RETROSPECTO HISTÓRICO E AS VICISSITUDES ATUAIS DO MERCADO DE CAPITAIS}

\section{ORIGEM E EVOLUÇÃO HISTÓRICA}

Desde a origem do Homem até a Idade Média (mas antes do Renascimento), pode-se dizer que a História Econômica indica a existência apenas de sociedades précapitalistas, tratando-se de período em que surgiu a agricultura e antecedeu a época da formação das grandes civilizações da Antiguidade, período em que os homens concentravam-se nas caças, enquanto que as mulheres voltavam-se apenas para a colheita, sendo esta a divisão de trabalho vigente desde o surgimento das sociedades paleolíticas.

Nesse sentido, vide comentários de Ricardo Feijó:

"Nas sociedades pré-capitalistas, em geral, há uma tradição cultural que permeia a vida econômica e que condiciona fortemente a maneira como os homens relacionam-se na produção e na distribuição de bens. Não predomina nelas uma lógica de mercado a comandar os papéis individuais e nem há a impessoalidade típica das economias capitalistas. Os indivíduos não pautam suas ações pela busca pessoal de riqueza. $O$ que move as pessoas nas sociedades tradicionais pré-capitalistas é a representação de um papel já estabelecido que lhes é fornecido ao nascerem e que passa a ditar suas vidas. Elas não estão, portanto, livres na vida econômica para alcançarem toda vantagem possível. A participação de cada qual é ditada pela tradição que ensina as pessoas como e para quem produzir.

A consequência maior do forte predomínio da tradição cultural na vida econômica é a impossibilidade de se identificar uma recorrência de fatos econômicos que possam ser racionalmente interpretados. Os preceitos 
que ditam a atividade produtiva nessa sociedade são de natureza cultural e podem não obedecer a nenhum critério racional. Nela, a visão de um mundo transcendental de mitos e deuses comanda ações econômicas ordinárias. Com isso, todas as dimensões culturais permeiam o fenômeno puramente econômico e não se pode separá-lo delas, mesmo para fins analíticos.",20

Entre os anos 8.000 a. C. até 3.500 a. C., a História Econômica relata a ocorrência da primeira revolução econômica, que ficou conhecida por Revolução Neolítica, a qual foi motivada, segundo Jacques Brasseul ${ }^{21}$, por bruscas mudanças nas condições climáticas. Com a referida revolução econômica, $(i)$ há o surgimento de aldeias e cidades, (ii) a existência de excedentes na agricultura leva à modificação da divisão do trabalho até então vigente, sendo que as mulheres passam também à dedicação da criação de animais e ao cultivo de cereais, (iii) surgem os primeiros serviços ligados à organização da atividade econômica essencial da época, que era a cultura do solo e (iv) há, ainda, um incremento nas trocas dos excedentes.

Somente na Antiguidade, a partir de 4.000 a. C., como consequência da Revolução Econômica do Neolítico, há uma intensificação dos direitos de propriedade, momento em que surgem as primeiras formas de Estado ${ }^{22}$, cujas principais características, segundo Dalmo de Abreu Dallari ${ }^{23}$, residem na sua unitariedade, ou seja, inexistia divisões internas, seja em seu território, seja em termos administrativos e funcionais, bem como na religiosidade, quer dizer, o Estado era visto como expressão direta do poder religioso, do poder divino.

A Revolução Econômica Neolítica difundiu-se pela região do Rio Nilo, da Índia e da China no ano 4.000 a. C. e, somente em 2.500 a. C., na região da Europa. Esta difusão da revolução econômica deu ensejo ao surgimento dos primeiros grandes centros

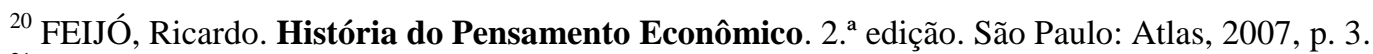

${ }^{21}$ BRASSEUL, Jacques. História Econômica do Mundo: Das Origens aos Subprimes. $2^{\mathrm{a}}$ edição. Lisboa: Edições Texto \& Grafia, 2010, p. 44 - 60.

${ }^{22}$ Segundo Dalmo de Abreu Dallari, deve-se entender por Estado como sendo "todas as sociedades políticas que, como autoridade superior, fixaram as regras de convivência de seus membros." (DALLARI, Dalmo de

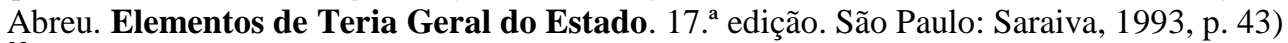

${ }^{23}$ DALLARI, Dalmo de Abreu. Elementos de Teria Geral do Estado. 17. a edição. São Paulo: Saraiva, 1993 , p. 53 - 54.
} 
urbanos, de uma complexa organização social e do início da metalurgia, culminando com o nascimento das grandes civilizações e com a formação de diversos impérios, que, basicamente, dividiram-se em duas espécies: os impérios da terra (civilizações dos grandes rios Tigres e Eufrates, Suméria à Pérsia, Nilo), que eram fundados na agricultura, e os impérios do mar (Fenícia, Cidades Gregas e Reinos Helenísticos), que estavam fundados no comércio e na navegação.

Nos impérios da terra, a economia era dotada de um caráter liberal (précapitalista) e fomentadora das atividades comerciais privadas, além de ser propícia a trocas, bem como à difusão das técnicas, apresentando uma organização coordenada pelos homens, cujo funcionamento era garantido por normas jurídicas garantidores, essencialmente, da propriedade e que eram implementadas pelo Estado. As principais produções eram agrícolas, sendo que a criação de animais era apenas uma fonte complementar de alimento e de força de trabalho. Diante da falta de matéria-prima, constata-se a necessidade de importar e exportar em larga escala, o que leva ao desenvolvimento de entrepostos, de casas de comércio e à presença dos primeiros banqueiros em razão do uso de moeda e do crédito para as trocas.

Já os impérios do mar criaram o comércio marítimo fundado mais nas trocas que na produção, destacando-se como intermediários em todas as trocas do mundo antigo. $\mathrm{Na}$ qualidade de intermediários, os impérios do mar desenvolveram feitorias para o incremento das trocas, sendo os primeiros colonizadores, além dos marinheiroscomerciantes praticarem uma forma livre de empresa marítima. A Fenícia foi o primeiro império do mar fundado no Século XII a. C.. Já, por volta entre os Séculos V e IV a. C., os impérios do mar aperfeiçoam uma economia comercial, marítima e monetária, proporcionando a unificação de pesos e medidas, além de difundirem o uso da moeda, agora utilizada em larga escala, dando causa ao surgimento de um comércio internacional, que era centrado em Atenas, voltado ao lucro e fundado no direito de propriedade e nos contratos já mais evoluídos, bem como na divisão do trabalho.

Segundo Jacques Brasseul, o Império Romano destacou-se justamente por ser, simultaneamente, um império da terra e do mar, ou seja, o êxito do Império Romano deve-se à capacidade de síntese das duas espécies de impérios da Antiguidade, além de 
outros fatores, tais como "a organização militar, instituições estáveis (...), um patriotismo lendário que se traduz numa dedicação total quer do povo (plebs) quer das elites e, por último, a abertura e a capacidade de assimilação que permite a integração relativamente harmoniosa das nações vencidas." 24

Como bem narrou Ricardo Feijó, observou-se uma intensificação do comércio no Império Romano, sem que houvesse um desenvolvimento no pensamento econômico, in verbis:

"Desenvolve-se o comércio entre regiões, também facilitado pela adoção de moedas para intermediar as trocas. Instituições de créditos similares ao cheque e notas promissórias eram conhecidas e usadas. Há banqueiros profissionais e até um banco público para supervisionar suas atividades. O governo tem de enfrentar problemas econômicos típicos da era moderna como crises monetárias e fiscais, falta de ouro, balança comercial deficitária e inflação. Os imperadores intervêm de muitas formas na vida econômica, fixando preços, tabelando juros, protegendo devedores, inspecionando a qualidade dos bens nos mercados, confiscando mercadorias defeituosas ou estragadas. Também atuam com medidas contra a competição estrangeira, outras que regulam o uso das vias públicas, que proíbem a exportação de metais preciosos e até organizando as profissões em corporações obrigatórias.

Com tudo isto, era de se esperar que o pensamento econômico tivesse grande desenvolvimento no período, mas tal fato não ocorreu (...) Isso se explica pelo fato de a cultura romana ter desenvolvido um viés bastante pragmático: os romanos são homens de ação e estão mais preocupados com ideias concretas sobre relações econômicas, de aplicação imediata nos negócios do dia-a-dia, e menos voltados à análise puramente teórica." 25

\footnotetext{
${ }^{24}$ BRASSEUL, Jacques. História Econômica do Mundo: Das Origens aos Subprimes. $2^{\mathrm{a}}$ edição. Lisboa: Edições Texto \& Grafia, 2010, p. 53.

${ }^{25}$ FEIJÓ, Ricardo. História do Pensamento Econômico. 2. ${ }^{a}$ edição. São Paulo: Atlas, 2007, p. 22.
} 
Não obstante o não desenvolvimento do pensamento econômico, os romanos tinham como principal fonte do pensamento econômico o sistema legal romano, ou seja, enquanto resultado da elaboração de leis com impactos econômicos, sem dar, inclusive, grande importâncias às considerações éticas e religiosas ${ }^{26}$.

Embora o Império Romano não apresentasse uma sistematização das normas de Direito Comercial, como bem indicou Tulio Ascarelli ${ }^{27}$, o referido império deu grandes contribuições para o progresso econômico, a partir do momento em que as conquistas concretizadas pelo Império Romano provocou uma intensificação, no plano comercial, em regiões que apresentavam baixa intensidade comercial, visto que o Império necessitava importar produtos agrícolas daquelas regiões conquistadas, os quais eram cada vez menos produzidos internamente.

No auge do Império Romano, além do florescimento das trocas comerciais fora do âmbito das cidades, abrangendo regiões mais afastadas, neste momento, segundo os relatos de Jacques Brasseul, surgem os bancos em Roma, que se torna uma verdadeira capital financeira. Contudo, com a queda do Império Romano, assiste-se à adoção de inúmeras medidas coercitivas, que "destroem paulatinamente a mobilidade dos fatores e os mecanismos de mercado, substituindo uma economia de trocas monetárias por uma cristalizada economia de subsistência." 28

Assim, a Antiguidade foi um período da História Econômica Mundial que apresentou uma estabilidade das técnicas, de forma que as inovações (tais como a moeda, a

\footnotetext{
26 "A principal fonte de ideias econômicas na Roma Antiga localiza-se no sistema de leis. Há um pensamento econômico original e fértil entre os juristas romanos. Na elaboração das leis com impacto na economia, esses juristas tendiam a dar menos importância a considerações éticas e religiosas. A inclinação predominante era ver a esfera econômica como dominada pela ação de forças impessoais. Tal fato representa um afastamento em relação aos povos antigos que não separavam a esfera econômica da dimensão ética e política, mas não se pode exagerar essa interpretação a ponto de se falar em teorias de sistema econômico imbuído de racionalidade própria. A partir dos romanos, porém, inicia-se um caminho em direção a essa perspectiva que somente se desenvolve no nascimento da Economia como ciência no século XVIII." (FEIJÓ, Ricardo. História do Pensamento Econômico. 2. ${ }^{a}$ edição. São Paulo: Atlas, 2007, p. $22-23)$

27 “ $O$ direito romano não tinha conhecido um sistema de direito mercantil e a isso talvez contribuía também a elasticidade do direito pretório (com a conseguinte dicotomia do sistema a que temos feito referência no parágrafo anterior), e a elaboração das instituições denominadas juris gentium através das quais se satisfaziam as exigências internacionais a que, como veremos, respondeu nas suas origens o direito mercantil." (ASCARELLI, Tulio. Iniciação ao Estudo do Direito Mercantil. Sorocaba: Minelli, 2007, p. 42)

${ }^{28}$ BRASSEUL, Jacques. História Econômica do Mundo: Das Origens aos Subprimes. $2^{\mathrm{a}}$ edição. Lisboa: Edições Texto \& Grafia, 2010, p. 56.
} 
escrita etc.), não obstante a importância na evolução da Humanidade, não estavam ligadas à produção e muito raramente proporcionavam alguma contribuição ao crescimento econômico $^{29}$. E as causas desta dissociação entre técnicas e produção, segundo Jacques Brasseul, são atribuídas à organização da sociedade, in verbis:

“As causas prendem-se com a organização de uma sociedade baseada no trabalho forçado: a escravatura é pouco propícia ao progresso tecnológico, porque o produtor não está muito interessado no resultado do seu esforço; também as mentalidades, voltadas para a abstração e a filosofia na Grécia, o direito e a organização em Roma, estão pouco preocupadas com os processos produtivos, e as elites menosprezam tais aspectos materiais; os valores são os do poder político e não os da economia; por fim, as múltiplas superstições quem acompanham a religião greco-romana estão mais inclinadas para explicações mágicas do que para as explicações racionais dos fenômenos naturais e do funcionamento das coisas." ${ }^{30}$

Após a queda do Império Romano, que ocorreu no ano de 476, inicia-se o período da Idade Média, na qual há uma preocupação mais voltada ao progresso material, sem se desconsiderar o progresso espiritual, culminando, no fim do Renascimento (aproximadamente fins do Século XVII), com a presença de sociedades capitalistas préindustriais.

Na Idade Média, segundo Dalmo de Abreu Dallari ${ }^{31}$, constata-se uma alta instabilidade e heterogeneidade no âmbito do Estado, o que dificultou a síntese dos principais caracteres do Estado Medieval. Contudo, o Estado Medieval apresentou uma preocupação em obter uma unidade, além de força como forma de atingir uma unidade

\footnotetext{
29 "Parece que o mundo antigo se caracterizou por um vasto potencial técnico, mas efetivamente pouco desenvolvido. A navegação não evolui, ainda que sejam conhecidas técnicas mais eficazes, embora a economia se baseie no comércio marítimo; a metalurgia é primitiva e a energia hidráulica não permite praticamente fazer avançar a produção, por generalizada falta de aplicação. As invenções permanecem em estado de exemplares limitados ou de brinquedos engenhosos, e não se difundem, por falta de interesse pela produção." (BRASSEUL, Jacques. História Econômica do Mundo: Das Origens aos Subprimes. $2^{\mathrm{a}}$ edição. Lisboa: Edições Texto \& Grafia, 2010, p. 60)

${ }^{30}$ Idem, ibidem, p. 60.

${ }^{31}$ DALLARI, Dalmo de Abreu. Elementos de Teria Geral do Estado. 17. a edição. São Paulo: Saraiva, 1993 , p. 56 - 59.
} 
política e um poder eficaz e imune a influências, o que foi incentivado, sobretudo, pelas invasões bárbaras, mas sempre tendo como base fundamental o cristianismo que induz à busca da universalidade e da igualdade dos homens.

As constantes guerras e invasões dificultam o desenvolvimento do comércio, de modo que, "em consequência, valoriza-se enormemente a posse da terra, de onde todos, ricos ou pobres, poderosos ou não, deverão tirar os meios de subsistência. Assim, pois, toda a vida social passa a depender da propriedade ou da posse da terra, desenvolvendo-se um sistema administrativo e uma organização militar estreitamente ligados à situação patrimonial."32

Assim, inicia-se um período marcado por uma pluralidade de poder e autoridade, o que confere maior liberdade às cidades, que apresentam uma ascensão ao aumentarem a conquista de privilégios dentro da organização administrativa, sobretudo a partir do Século XI, chegando a concentrar a organização da produção manufatureira, culminando com a formação das corporações de ofícios. Nesta época, constata-se um aumento da divisão do trabalho e um aumento das trocas, além do aumento da produtividade agrícola e do incremento da técnica.

Entre os Séculos VIII a XI, assiste-se a um período de transição do sistema econômico da Antiguidade para o Feudalismo, marcado pela transição da escravidão para a servidão, período que ficou conhecido por Idade das Trevas ${ }^{33}$. Naquele período, surge um sistema econômico resultante da junção dos caracteres do mundo romano com os do mundo germânico, que pode ser denominado de sistema do grande domínio caracterizado pelo isolamento do homem em torno das grandes explorações rurais voltadas à subsistência, pela limitação das trocas, das permutas em um âmbito fechado, o que causa o

\footnotetext{
32 DALlARI, Dalmo de Abreu. Elementos de Teria Geral do Estado. 17. a edição. São Paulo: Saraiva, 1993 , p. 58.

33 “É vantajoso estudar o período dividindo-o em duas épocas. A primeira preside às mudanças radicais do estilo de vida europeu com o desaparecimento de cidades e a acentuada ruralização. Muitas práticas romanas são esquecidas e a Europa entra em período de menor fervor cultural. O poder político pulverizase ao mesmo tempo em que, lentamente, vão-se consolidando as instituições medievais (...) Enquanto a Europa mergulha na Idade das Trevas, os povos árabes conquistam um grande império (...) A relevância dos árabes nas ideias econômicas começa com a grande contribuição que foi o sistema de números inventado por eles. Os números arábicos facilitaram as tarefas aritméticas e certamente impulsionaram os processos de contabilização econômica e o desenvolvimento de uma primitiva Econometria." (FEIJÓ, Ricardo.

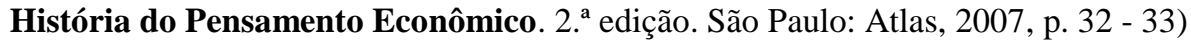


declínio do comércio e a baixa utilização da moeda, além da indústria limitar-se ao artesanato existente dentro do domínio.

A partir do Século XI, inicia-se um período de prosperidade na Europa que é marcado pela economia feudal ${ }^{34}$, que foi um sistema progressista que proporcionou o aumento da produtividade e o crescimento demográfico, graças ao período de paz que se iniciou após as invasões, aos excedentes de produção, bem como aos progressos técnicos no âmbito da produção entre os Séculos XI e XIII, decorrentes não da ciência, que ainda estava dissociada da atividade econômica, mas, sim, da própria atividade dos artesãos, camponeses, comerciantes e marinheiros.

Conforme Ricardo Feijó, este é um período de transição proporcionado pelo excedente da produção agrícola, que reativou a atividade comercial e, assim, deu origem a uma nova classe social que providenciará a dissolução gradativa das relações feudais:

"A vida econômica na sociedade medieval era sustentada pela atividade agrícola. Os feudos eram auto-suficientes e quase nunca produziam um excedente exportável. A partir do século XI, mudanças tecnológicas aumentaram significativamente a produtividade na agricultura e com isso pôde-se gerar crescentemente um excesso de produção destinado ao comércio. A atividade comercial dá origem a uma nova classe de homens enriquecidos sem vínculos fortes com a antiga ordem social. São os portadores do elemento que iria dissolver lentamente as relações feudais: a substituição dos vínculos medievais que existiam entre as pessoas, legitimados pela fé, por relações de mercado. Contudo, não foi uma transição linear; muitas guerras, revoltas e retrocessos ocorreriam até que o capitalismo comercial substituísse o feudalismo nos países mais adiantados da Europa., 35

\footnotetext{
34 "A atividade comercial é, de início, bastante limitada, embora ela venha a crescer a partir do século XI. A base da organização não está no contrato, mas nas relações de status. A palavra empenhada, a promessa verbal e a defesa da honra valem mais do que a lei escrita." (FEIJÓ, Ricardo. História do Pensamento Econômico. 2. ${ }^{a}$ edição. São Paulo: Atlas, 2007, p. 34)

${ }^{35}$ Idem, ibidem, p. 34-35.
} 
Já na segunda metade do Século $\mathrm{XII}^{36}$, assiste-se ao surgimento das corporações de artes e de ofícios, que congregam artesãos e comerciantes associados nas suas respectivas corporações, as quais apresentaram um grande desenvolvimento, quando se constata um deslocamento populacional do campo para as cidades, em virtude do aumento demográfico (excedente de mão de obra) e da criação de mercado consumidor para as manufaturas produzidas no entorno dos feudos dentro de núcleos urbanos que se transformarão em cidades ${ }^{37}$. Nesta época, as cidades exercem o importante papel de centro de $\operatorname{trocas}^{38}$, o que ocorria nas grandes feiras, ensejando, inclusive, o surgimento de novos meios de pagamento e de crédito, dando azo ao surgimento de bancos nos principais centros de comércio, em virtude da intensificação das trocas entre as diversas regiões da Europa, bem como externas à Europa, especialmente para o Oriente.

Em razão da intensificação do comércio, as corporações de comerciantes são as que se desenvolvem mais rapidamente e com maior especialização, apresentando um caráter mais empreendedor, o que desencadeará, nos Séculos XIII e XIV, nos empresários dedicados à atuação internacional, com uma verdadeira organização racional, acompanhada de uma ampla atividade bancária, manejando seus capitais e os capitais dos demais investidores, dando origem a um nascente capitalismo pré-industrial ${ }^{39}$. Nesta

\footnotetext{
36 “'A segunda etapa da Idade Média, tal como estamos caracterizando, vai de 1200 a 1500 . O grande divisor de águas foi o renascimento filosófico impulsionado pelo resgate da filosofia grega (...) É nesse segundo período medieval que a análise econômica terá um significativo avanço.” (FEIJÓ, Ricardo. História do Pensamento Econômico. 2. a edição. São Paulo: Atlas, 2007, p. 33)

37 "O enriquecimento de parte da população possibilitou mercado consumidor para manufaturas, cuja produção estabeleceu-se em núcleos urbanos em torno dos feudos ou que se formaram ao longo de rotas comerciais pelo interior do continente (...) Em breve, alguns desses centros transformam-se em cidades que pouco a pouco foram livrando-se da tutela dos senhores. O fluxo de manufaturas deu um impulso adicional ao comércio que vinha desenvolvendo-se para os produtos agropecuários. O aperfeiçoamento das carroças, a melhoria das estradas e a navegação costeira e dos rios permitiram o comércio de longa distância. No século XI, também contribuiu para impulsionar o comércio o fato político das Cruzadas: leva de europeus que se deslocavam a pé até a Terra Santa com o fito de expulsar dela os mulçumanos." (Idem, ibidem, p. 36)

38 "As cidades desempenham de novo o papel de encruzilhada de ideias e de trocas. As indústrias renascem sob a forma de corporações, guildas, hansas ou outras associações de ofícios (cf. caixa seguinte). Inicialmente, os burgueses são apenas habitantes da cidade, do burgo, mas formam pouco a pouco uma nova classe cujo papel é crescente. Grandes feiras como a de Champagne dão azo a que todos os comerciantes e fabricantes do continente troquem produtos. Incrementam-se novas técnicas de crédito e de pagamento, prefigurando o desenvolvimento financeiro do Renascimento. Surgem os bancos nos principais centros de comércio, que começam a praticar o câmbio, a compensação, os empréstimos e as transferências para evitar o transporte de moedas. Em suma, é toda a sociedade que se torna mais complexa por comparação com a época dominial (...) É uma verdadeira revolução comercial que caracteriza o despertar da Europa na Idade Média". (BRASSEUL, Jacques. História Econômica do Mundo: Das Origens aos Subprimes. $2^{a}$ edição. Lisboa: Edições Texto \& Grafia, 2010, p. 70)

39 “As corporações mercantis reúnem, junto aos pequenos comerciantes, de mentalidade artesãa, os grandes comerciantes (..) que, nos séculos XIII e XIV, são empresários com uma esfera de ação internacional, homens de negócios dedicados a múltiplas especulações, autênticos protagonistas de uma verdadeira
} 
época, surgem os primeiros documentos da dívida cambiária, que se destinavam aos pagamentos entre praças distantes com câmbio de moedas ${ }^{40}$.

As corporações dos comerciantes produzem uma disciplina regulamentadora dos negócios mercantis, especialmente fundada na mediação das trocas, cuja origem está alicerçada fundamentalmente nos costumes dos comerciantes com influxos do direito marítimo, mas de aplicabilidade específica aos comerciantes. Aos poucos as normas relativas aos negócios mercantis vão formando o direito mercantil, que, gradativamente, vai-se firmando como direito autônomo da classe profissional com nítido caráter internacional $^{41}$.

Segundo Tulio Ascarelli, nesta época, a atividade mercantil passa a requerer um maior investimento de capital, que ultrapassa a contribuição familiar, momento em que surge a figura da sociedade em nome coletivo, in verbis:

"A atividade mercantil exige o concurso da atividade e dos meios financeiros de uma pluralidade de pessoas, e neste período surge, desbordando o consórcio familiar, a sociedade em nome coletivo ('compagnia', como se dizia e como seguimos, substancialmente dizendo com o nosso 'e compagni') que reforça sua estrutura financeira, primeiro com participações alheias e depois, no século XIV, mais frequentemente com depósitos, o instrumento típico para a organização do comércio terrestre e da atividade bancária, num princípio ilustra Sapori - com uma estrutura unitária respeito às numerosas filiais que a grande companhia tinha em toda Europa, depois, na segunda metade do

atividade econômica de alcance internacional, com uma ordenada e racional organização, frequentemente com uma ampla atividade bancária, instrumento de intensa atividade financeira da Igreja que, assim, indica com agudeza Sapori, apadrinhou o nascente capitalismo." (ASCARELLI, Tulio. Iniciação ao Estudo do Direito Mercantil. Sorocaba: Minelli, 2007, p. 44 - 45)

40 "Aos pagamentos entre praças afastadas, e por isso com câmbio de moeda, serve uma nova instituição, quer outra parte nos apresenta um esquema afastado do usado ainda hoje para aquela mesma finalidade especialmente nos chamados (quando estão em contraste com a legislação sobre os câmbios, ilícitos) 'bonifici'.

Os primeiros documentos se remontam ao século XII e sua afirmação plena se dá no século XIII." (Idem, ibidem, p. 53)

41 "O caráter internacional do direito mercantil assim formado, revela-se na sua expansão, incluso mais acentuada que a do direito romano-canônico-comum."(Idem, ibidem, p. 49) 
Século XIV, com uma autonomia das fazendas locais que fazia de casa mãe a holding das primeiras.

No comércio marítimo dominava, não obstante, a comenda e, referindose a esta e a sua difusão também fora do comércio marítimo, virá depois disciplinada (pela primeira vez na lei florentina de 1408) a comanditária." ${ }^{, 42}$

Assim, constata-se que a economia feudal, que inicialmente era pouco monetizada, passa a utilizar a moeda como meio de pagamento ${ }^{43}$ em substituição às prestações em gênero, o artesanato é substituído pelos manufaturados da cidade voltados à comercialização nos mercados, a qual se intensifica. Não obstante, a agricultura ainda representava a quase totalidade da produção, o que levou a Europa à crise generalizada no Século XIV, que foi agravada por desastres naturais, volta das guerras, rápido aumento da população não acompanhado pelos recursos e epidemias (peste negra a partir de 1347), o que culmina com a crise do sistema feudal e do próprio comércio, findando a Idade Média com a queda de Constantinopla em 1453 e dando, assim, início à Idade Moderna.

A crise vivida no fim da Idade Média levará ao início do surgimento gradativo das Monarquias Absolutistas ${ }^{44}$, que se caracterizaram por uma presença estatal maior nos setores militar, político e econômico, sendo o Estado o garantidor da proteção, da segurança e dos direitos de propriedade em troca do pagamento de novos tributos, além de fomentador do comércio e das atividades manufatureiras. Trata-se da origem do Estado Moderno que se consolida a partir do Século XVI, cujas características primordiais se concentram no entorno dos conceitos de soberania nacional, território, povo e finalidade

\footnotetext{
${ }^{42}$ ASCARELLI, Tulio. Iniciação ao Estudo do Direito Mercantil. Sorocaba: Minelli, 2007, p. 58.

43 "Nos séculos XII e XIII, o desenvolvimento econômico estimulou a atividade financeira. Aparecem os primeiros banqueiros que recebem depósitos pagando juros por eles. A doutrina econômica de cunho moral ia cedendo à prática econômica e a Igreja passava a influenciar os reis para que permitissem os juros, mas regulassem o calor cobrado (...) À medida que as cidades comerciais foram adquirindo autonomia, seus dirigentes procuravam estabelecer um código legal preciso em substituição ao direito consuetudinário e paternalista do feudalismo. As transações comerciais e financeiras foram então regulamentadas por uma legislação comercial específica. Tal legislação permitiu incrementar o comércio, pelas leis de contrato, legalização das representações comerciais e das vendas em leilão, e criar novos instrumentos e operações financeiras, tais como letras de câmbio e outros papéis negociáveis, câmaras de liquidação de dívidas etc." (FEIJÓ, Ricardo. História do Pensamento Econômico. 2. ${ }^{a}$ edição. São Paulo: Atlas, 2007, p. 37)

44 "Já no século XIII o monarca vai ampliando a esfera de sua competência exclusiva, afirmando-se soberano de todo o reino, acima de todos os barões, adquirindo o poder supremo de justiça e de polícia, acabando por conquistar o poder legislativo." (DALLARI, Dalmo de Abreu. Elementos de Teria Geral do Estado. 17. ${ }^{\text {a }}$ edição. São Paulo: Saraiva, 1993, p. 64)
} 
pública do Estado, além da desvinculação da Igreja. Ademais, o Estado Moderno apresenta uma maior preocupação em disciplinar o mercado nacional, momento em que inicia-se, no âmbito jurídico, uma nova concepção de direito que se associa à ideia do humanismo e de formação de um direito nacional comum que se consolidará na segunda metade do Século XVI.

Entre o período de decadência do feudalismo e o início da Idade Moderna, o mercantilismo serviu como regime de transição para o capitalismo ${ }^{45}$, o qual veio acompanhado dos Estados Absolutistas, além de se tratar de um regime de transição muito fértil no âmbito do pensamento econômico. O mercantilismo também foi marcado pela associação dos Monarcas com os burgueses em detrimento da antiga classe dos senhores feudais, o que serviu para permitir a centralização do poder nas mãos dos Reis Absolutistas em desfavor da típica descentralização do poder que marcou o feudalismo.

Nesse sentido, vide os comentários de Ricardo Feijó:

"A doutrina mercantilista teve origem na prática dos reis medievais $e$ gradualmente foi firmando-se como racionalização das políticas intervencionistas que já vinham sendo adotadas. À medida que a classe de comerciantes e financistas enriquecia, ela ganhava importância na sociedade medieval e os nobres feudais, sentindo a ameaça ao status quo, compeliam o rei a tomar medidas para controlar a atividade mercantil de modo a limitar o enriquecimento com o comércio (...) Em nome do nacionalismo, o rei foi acumulando poderes, ao mesmo tempo e que a nova classe ligada ao comércio ia conquistando seu espaço. Isso levou no fim do século XIV à associação entre monarcas e burgueses, o que garantiu a centralização do poder em detrimento da antiga classe de

\footnotetext{
45 “Em 1763, Victor de Riqueti, o Marquês de Mirabeau (1715-1789), cunhou a expressão mercantilismo para caracterizar o conjunto de doutrinas econômicas dominadas pelo nacionalismo e pelo intervencionismo que, já presentes no final da Idade Média, ganham impulso nos séculos XVI e XVII. O mercantilismo é a contrapartida, no plano das ideias econômicas, do ambiente intelectual e político que acompanha o aparecimento de Estados nacionais centralizados e fortes. Da perspectiva histórica, ele é considerado um período de transição entre as práticas regulamentatórias da economia no feudalismo, marcadas pelo fervor ético e religioso, e o nascimento das concepções liberais no século XVII." (FEIJÓ, Ricardo. História do

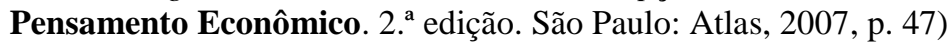


senhores feudais. Surge o nacionalismo exacerbado nos recém-criados Estados-nações que conferiam poderes absolutos e divinos ao rei." ${ }^{46}$

É justamente neste ambiente que, entre os Séculos XV e XVI, iniciam-se as grandes navegações, período em que surgem novas formas de intercâmbio lançadas pelos armadores e mercadores, as descobertas de novos mercados além-mar, a criação de institutos favoráveis ao progresso econômico, ao aumento da produtividade, criando bases favoráveis à futura Revolução Industrial. Já em 1487 surge a Bolsa de Bruges, atual Bélgica, que era dirigida pela Família Van der Burse e, inicialmente, destinava-se à compra e venda de moedas, de metais preciosos e de letras de câmbio.

Até o final do Século XV, a China possuía um grande avanço técnico em comparação ao continente europeu, conforme relata Jacques Brasseul:

“O avanço da China em matéria técnica até essa altura por comparação com todas as outras civilizações é explicável simplesmente pelo número. Antes dos tempos modernos, as invenções resultam, na sua maioria, da experiência dos artesãos, dos rendeiros e de alguns gênios isolados, que descobrem fortuitamente novos processos mediante a observação da Natureza e dos seus mecanismos. Quanto maior é a população, maiores são as possibilidades de descobertas felizes e úteis; graças ao seu peso demográfico, a China realizará o maior número de progressos tecnológicos e científicos (altos-fornos, teares, relógios hidráulicos, papel, pólvora, bússula, leme, tipografia, ímã, adubo, máquinas agrícola, etc.). Assim, (...) entre o século I a.C. e o século XV, a civilização chinesa era muito mais eficaz do que a civilização ocidental a aplicar os conhecimentos para suprir as necessidades humanas fundamentais". 47

Os europeus utilizaram tecnologias desenvolvidas pelos chineses e as aplicaram para dar início às grandes navegações a partir do final do Século XV, dando,

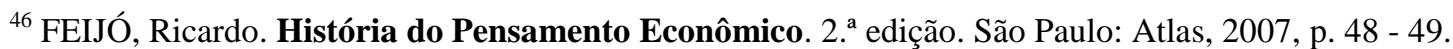

${ }^{47}$ BRASSEUL, Jacques. História Econômica do Mundo: Das Origens aos Subprimes. $2^{\mathrm{a}}$ edição. Lisboa: Edições Texto \& Grafia, 2010, p. 37.
} 
assim, início a um período de intenso fluxo de mercadorias, de forma que o comércio recebeu um novo impulso, especialmente em razão do comércio realizado além-mar.

Até o fim da Idade Média, pode-se dizer que as sociedades eram apenas précapitalistas, visto que não estavam, ainda, presentes as características principais do capitalismo enquanto regime econômico. Assim, nas sociedades pré-capitalistas (i) o direito de propriedade não era extensivo a todos, (ii) não havia liberdade econômica, mobilidade de trabalho, tampouco mobilidade perfeita de mercadorias, (iii) não havia um sistema de mercado livre que abrangesse toda a economia, mas havia mercados isolados, não interligados, motivo pelo qual as feiras serviam de estímulo para as trocas, (iv) os valores morais, militares e espirituais eram hostis à atividade econômica e (v) apesar de haver um período de criatividade técnica e de crescimento econômico, o regime précapitalista apresentava mudanças lentas.

Com o início da Idade Moderna, surgem as economias capitalistas préindustriais, estimuladas pelas condições de crescimento econômico que o Continente Europeu apresentava. Durante o Renascimento (Séculos XV e XVI) e a Idade Clássica e Barroca (Séculos XVII e XVIII), o ideal econômico dominante era o mercantilista, período marcado pela economia mercantilista que serviu de regime de transição entre a Idade Média e a Era Industrial. A economia, neste período de transição, apresentou algumas mutações: (i) após os descobrimentos, as trocas mercantis passaram a ser ultramarinas, (ii) os Estados-nações consolidaram-se, apresentando um intenso intervencionismo e dirigismo no âmbito da política econômica ${ }^{48}$, (iii) desenvolvimento das classes burguesas nas cidades, (iv) surgimento de pensamentos favoráveis à atividade econômica, em contraposição aos valores morais, espirituais e militares até então vigentes e que eram hostis à atividade econômica, (v) criação de diversos institutos e instituições fomentadores do desenvolvimento econômico e (vi) predomínio do espírito científico e racionalista em substituição às crenças mágicas e irracionais.

No Século XVI, Portugal e Espanha são os países pioneiros e responsáveis pelo desenvolvimento do comércio ultramarino, que predominará na economia mundial

48 "A formação do Estado moderno subordina, observa Luzzatto, as unidades locais, assim como as formações corporativas, ao Estado que, pelas necessidades totalmente novas de suas finanças, tem que se interessar dos problemas econômicos da nação levando a cabo a política que se chamará mercantilista." (ASCARELLI, Tulio. Iniciação ao Estudo do Direito Mercantil. Sorocaba: Minelli, 2007, p. 62) 
por muitos séculos. Outros países europeus seguiram o exemplo daqueles países ibéricos e, assim, passaram a realizar expedições exploradoras voltadas para o comércio ultramarino. Neste período, pode-se dizer, mais uma vez, conforme indicou Tulio Ascarelli ${ }^{49}$, que se findou um primeiro ciclo de formação do direito mercantil voltado, basicamente, ao comércio, aos transportes, especialmente o marítimo, aos negócios bancários e cambiais, cuja origem estava nos usos e costumes dos comerciantes, apresentando, o sistema de direito mercantil, uma abrangência geral e vinculado a uma primeira ideia de mercado, embora tenham sido elaboradas para regular as atividades mercantis dos comerciantes, de modo a assumir uma feição independente das corporações que deram origem àquele sistema, além de destinar-se a proporcionar o aumento da riqueza de um modo geral e não restrita a um grupo determinado.

Justamente no seio desta economia mais dinâmica, que proporcionou a retomada da atividade econômica e do crescimento econômico europeu, sob os impactos dos grandes descobrimentos que, em suma, propiciaram um grande afluxo de metais preciosos e uma maior extensão das trocas mercantis, bem como no momento em que os aspectos políticos e institucionais passam a prevalecer em relação à esfera econômica, segundo os relatos históricos, a sociedade por ações foi criada.

Já, neste período, a economia era baseada fundamentalmente sobre o crédito, diante do gradativo abrandamento que a proibição canônica referente à cobrança de juros sofreu no decorrer dos anos, a partir do momento que se admite a cobrança de remuneração nos mútuos destinados à finalidade produtiva, justamente porque o tomador do empréstimo teria a sua contrapartida no rendimento que obteria da aplicação do dinheiro, por exemplo, na aquisição de bens, em detrimento dos benefícios que o credor poderia obter se ele próprio aplicasse o dinheiro emprestado ${ }^{50}$. A propósito, a legislação já reconhecia a licitude da cobrança de juros.

\footnotetext{
49 "Deste modo forma-se um primeiro núcleo, um primeiro sistema, de direito mercantil, essencialmente em função do comércio, dos transportes (sobretudo marítimos, já que, como temos lembrado, são com frequência instituições marítimas - sobretudo o avultado empréstimo - as que, no seu desenvolvimento, dão lugar a instituições gerais do direito mercantil) e dos negócios bancários e de câmbio; um direito fruto do costume dos comerciantes, cujos negócios disciplina, e em relação com um processo que assume formas simples e expeditas (sumárias e sumariíssimas, como se diz) em jurisdições especiais." (ASCARELLI, Tulio. Iniciação ao Estudo do Direito Mercantil. Sorocaba: Minelli, 2007, p. 59)

50 "O quadro muda numa economia baseada sobre o crédito, na qual o dinheiro é preferentemente dado em mútuo com: fins de produção, já que os interesses pagos pelo devedor encontram contrapartida nos frutos
} 
Em 1531, em razão da intensificação das trocas comerciais e em virtude de sua melhor localização, se comparada com a localização dos portos ibéricos, surgiu a primeira bolsa de comércio na Antuérpia, que era voltada para a realização de operações financeiras, trocas de títulos e de capitais, além de operações de especulação a prazo. Justamente por estar voltada a operações primordialmente de empréstimos, não foi aquela bolsa de comércio considerada como bolsa de valores ${ }^{51}$.

Ademais, a expansão mercantilista com a formação de colônias acabou dando origem à necessidade de capitais vultosos e sujeitos a grandes riscos, tendo em contrapartida a mera expectativa e esperança de obter grandes benefícios, o que denotava a incompatibilidade da forma societária surgida antes da expansão colonial, cuja estrutura era essencialmente pessoal e não eram vocacionadas a novas iniciativas empreendedoras.

Até o início do Século XVII, no âmbito mundial, não havia um instituto jurídico que reunisse todos os caracteres típicos da sociedade anônima, tal como a conhecemos hodiernamente.

Assim, exemplificativamente, as corporações eclesiásticas, embora tenham dado origem ao instituto da personalidade jurídica, não reuniam as demais características típicas das sociedades anônimas, o mesmo ocorrendo com as Rheederein, que eram uma associação para armação de navios, na qual os interesses estavam divididos em quotasparte com livre circulação.

Dos relatos históricos consultados, somente no ano de 1602 foi criada a primeira sociedade anônima, que foi a Companhia Holandesa das Índias Orientais, conhecida também por Companhia Unificada das Índias Orientais ou simplesmente VOC (Verenigde Oost-Indische Compagnie). A sociedade por ações foi, desse modo, o instrumento utilizado para possibilitar a expansão colonial, como indicou Tulio Ascarelli, in verbis:

obtidos dos bens adquiridos com o dinheiro dado em mútuo; na perda dos benefícios que o credor teria podido realizar colocando diretamente o dinheiro." (ASCARELLI, Tulio. Iniciação ao Estudo do Direito Mercantil. Sorocaba: Minelli, 2007, p. 56)

${ }^{51}$ BRASSEUL, Jacques. História Econômica do Mundo: Das Origens aos Subprimes. $2^{\mathrm{a}}$ edição. Lisboa: Edições Texto \& Grafia, 2010, p. 96. 
"A expansão colonial exige grandes capitais, dispostos a correr enormes riscos, com a esperança de benefícios fabulosos, capitais que nem sequer os grupos financeiros mais ricos podem ter a ponto por si sós. A reunião de grandes capitais exige a sua vez a possibilidade de que as participações individuais circulem, porque uma inversão é tanto mais fácil quanto mais fácil é, para quem tem invertido, a possibilidade de retirá-la. A estrutura das sociedades de comércio transmitida do período anterior, essencialmente pessoal, não se prestava a estas novas iniciativas, que deviam, por isso, buscar de outra parte uma própria estruturação jurídica. As cidades italianas do Renascimento, frequentemente endividadas, haviam criado um precedente através de associações dos próprios obrigacionistas (ou titulares de dívida pública) que, em garantia das utilidades de seus títulos, controlavam e ainda administravam determinados ingressos do próprio devedor, pelo que realmente exploravam empresas de cuja marcha dependia o benefício dos títulos; foi celebérrima, entre estas associações, o banco São Jorge de Gênova (...) Estes títulos (sendo juridicamente obrigações) circulavam livremente. Por outra parte, a indústria mineira, que se havia desenvolvido especialmente nos séculos XV e XVI, apresentava formas associativas capitalistas com participações suscetíveis de circulação.

Porém, o instrumento da expansão econômica colonial, e é a vez da origem da sociedade por ações modernas, surge da confluência das formas associativas econômicas com o conceito de personalidade jurídica elaborado no campo do direito público, que se produz na segunda metade do século XVI e no XVII, através da constituição de companhias privilegiadas, consagradas a atividades mercantis, dotadas à sua vez de privilégios e com um acento público, devendo ao ato da autoridade, ao que está subordinada sua constituição, a concessão da personalidade." 52

${ }^{52}$ ASCARELLI, Tulio. Iniciação ao Estudo do Direito Mercantil. Sorocaba: Minelli, 2007, p. 72 - 73. 
Com a criação da primeira companhia colonial na Holanda, surgiu, também, a primeira bolsa de valores em Amsterdam, em 1602, com os principais contornos das bolsas de valores modernas ${ }^{53}$, cuja operação incluía a negociação de ações da Companhia Holandesa das Índias Orientais, o que desencadeará, posteriormente, a criação da Bolsa de Londres no Século XVII e da Bolsa de Paris no Século XVIII.

$\mathrm{Na}$ época dos grandes descobrimentos, via de regra, o Estado Absolutista associava-se a súditos comerciantes que tinham disponibilidade de capital para investimento, os quais, dessa maneira, formavam as companhias coloniais que, por sua vez, reuniram, pela primeira vez na história, as características típicas das sociedades por ações, especialmente, a divisão do capital em ações e a limitação da responsabilidade dos sócios ao valor de suas ações, mas, em regra, sob o domínio do Estado Absolutista, tal como se observou em Portugal e França. Contrariamente a este padrão, tanto a Inglaterra, quanto a Holanda, que foram países não afetados pela estagnação econômica do Século XVII, atribuíam a criação e a administração das companhias de comércio à esfera privada. Estava iniciada, portanto, a primeira fase das sociedades anônimas, que eram marcadas pelo predomínio absoluto dos interesses do Estado.

Assim, pode-se dizer que as companhias coloniais constituem o imediato antecedente embrionário das sociedades por ações, que, nesta época, apresentavam as seguintes características principais: (a) a participação no empreendimento era aberta a todos; (b) a participação era representada por ações, cujo nome derivou da ação que o participante tinha para ser tutelado contra a companhia; (c) as ações circulavam livremente por meio de endosso; (d) as ações eram nominativas, sendo que, conforme Tulio Ascarelli $^{54}$, as ações ao portador somente teriam surgido no Século XVIII; $(\boldsymbol{e})$ a estrutura organizacional da sociedade por ações era muito primitiva, uma vez que ainda não se tinha a ideia de exercício social, de prestação de contas a cada expedição realizada, os dividendos eram pagos em mercadorias adquiridas no além-mar e não em dinheiro como

\footnotetext{
53 “(...) assume, com o século XVII, em Amsterdam, caracteres modernos, abarcando a negociação de ações das companhias então já existentes e desenvolve-se com características que se mantiveram constantes; a liquidação por diferença; as operações fixas e a prêmio; a concentração em um único lugar e em horas determinadas de agentes para a aquisição e a venda, com a conseguinte concentração das operações; a formação e as oscilações de um preço de mercado derivado das demandas e as ofertas, que provém não somente das exigências de inversão reais senão do propósito de especular com os preços baseando-se nas previsões sobre o andamento da bolsa." (ASCARELLI, Tulio. Iniciação ao Estudo do Direito Mercantil. Sorocaba: Minelli, 2007, p. 76 - 77)

${ }^{54}$ Idem, ibidem, p. 75.
} 
ocorre na atualidade, $(\boldsymbol{f})$ os acionistas podiam ser de duas espécies, aqueles que podiam participar da assembleia e exercer cargos sociais, bem como acionistas de categoria inferior, que apenas tinham direito aos dividendos e à quota de liquidação e ( $g$ ) responsabilidade limitada dos acionistas apenas perante terceiros, sendo ilimitada internamente na sociedade.

O Século XVII foi marcado pela economia mercantilista, que iniciava um período de estagnação, diante da diminuição da remessa de ouro e prata do Novo Mundo, além do desequilíbrio gerado entre a população que havia apresentado um grande crescimento demográfico e os recursos, além da agricultura apresentar-se estacionária no âmbito da técnica.

Não obstante a estagnação econômica ocorrida no Século XVII, no princípio deste Século, há o desenvolvimento da elaboração jurídica da letra de câmbio que gira em torno do problema de crédito e de sua circulação, mas que dará origem ao desenvolvimento de instrumentos jurídicos que serão aperfeiçoados no âmbito do mercado de capitais e do mercado financeiro por intermédio, respectivamente, das bolsas de valores e dos bancos.

Paralelamente a esta situação de estagnação e retração econômica, alguns países europeus não foram afetados pela depressão econômica em curso, tal como a Holanda, que apresentou instituições eficientes e que estimularam o desenvolvimento econômico, isto porque, na Holanda, mais da metade da população vivia nas cidades, o excedente agrícola era grande, visto que a agricultura apresentava-se muito produtiva. Além disso, a Holanda instituiu o regime de propriedade individual, o que serviu de estímulo ao progresso e o comércio apresentava-se próspero.

A Holanda, no Século XVII, foi considerada um país capitalista por excelência, pois (i) praticava a máxima do laissez faire, laissez passer internamente, (ii) o comércio e a indústria não estavam sujeitos aos regulamentos corporativistas, (iii) inventou o livre câmbio ao permitir que os portos fossem livres e ao taxar minimamente as mercadorias importadas e exportadas e (iv) iniciou o comércio multilateral moderno por todo o mundo e, ainda, sem visar ao equilíbrio das trocas em cada zona de comércio 
Assim, o êxito holandês estava fundado em quatro pilares básicos: (i) a fundação do Banco de Amsterdã em 1609, que praticava operações de câmbio e de crédito com baixas taxas de juros; (ii) a frota de navios holandeses dominava as frotas rivais; (iii) criação das Companhias das Índias Orientais com poderes verdadeiramente estatais na Ásia; e (iv) diversas instituições favoráveis ao mercado e aos direitos de propriedade. Estes pilares explicam o êxito econômico holandês, conforme explica Jacques Brasseul:

"O êxito econômico explica-se também pelas instituições favoráveis ao mercado e aos direitos de propriedade, abandonando os monopólios das corporações e as obrigações feudais. Graças a elas, os custos de transação foram mais contidos do que noutros lugares. Assim, a extensão das relações de mercado, as feiras e as bolsas limitam os custos de informação. Os custos de negociação baixam pela generalização das práticas codificadas pela lei e baseadas numa maior confiança dos cambistas. Por fim, os custos de aplicação dos contratos foram igualmente reduzidos pela generalização dos homens da lei (como notários, juízes e advogados), pela certeza de que a fraude seria sancionada e as práticas leais seriam mais vantajosas a prazo."

Outro país que não sofreu as consequências da estagnação econômica foi a Inglaterra, que apresentava uma política econômica mercantilista, mas impregnada por medidas liberais, especialmente favoráveis à proteção dos direitos de propriedade. No âmbito externo, a Inglaterra fomentava as atividades marítimas e comerciais, sem prejuízo da reserva do transporte aos navios ingleses. Neste Século XVII, surgiram, na Inglaterra, as companhias de seguros marítimos e as companhias de comércio e, já no final do Século XVII, a Inglaterra passou a utilizar o modelo das sociedades por ações em outros setores, mas nos mesmos moldes das companhias de comércio.

Não bastasse o êxito econômico da Inglaterra, tornando-a imune às consequências da estagnação econômica da época, as ciências exatas e sociais apresentaram um progresso, sendo que, ainda no Século XVII, a ciência foi introduzida nas técnicas de produção, o que proporcionou um progresso técnico-produtivo. Assim, houve

${ }^{55}$ BRASSEUL, Jacques. História Econômica do Mundo: Das Origens aos Subprimes. $2^{\text {a }}$ edição. Lisboa: Edições Texto \& Grafia, 2010, p. 106 - 107. 
uma alta taxa de crescimento intenso acompanhado de mutações técnicas, dando origem, assim, à revolução agrícola liderada pelos landlords, verdadeiros pioneiros da agricultura científica que conseguiram racionalizar a produção, implantar métodos agrícolas que aumentaram a produtividade, com alta capacidade de captação de capitais necessários ao investimento e, consequentemente, com uma elevação dos rendimentos.

A revolução agrícola foi considerada como condição precedente da revolução industrial ocorrida no Século XVIII ${ }^{56}$, pois, com o aumento da produtividade, a agricultura liberou mão de obra necessária e o excedente produtivo para alimentar os trabalhadores urbanos. Ademais, (i) forneceu produtos e matérias primas que seriam transformados pelas fábricas, (ii) forneceu mercado para os produtos manufaturados ao serem adquiridos para uso na agricultura, (iii) possibilitou a poupança a ser investida na indústria e, ainda, (iv) forneceu divisas por meio da exportação, que foram utilizadas na importação de matérias primas e bens de produção necessários ao desenvolvimento industrial.

Precedentemente à Revolução Industrial, constatou-se uma espécie de revolução financeira na Inglaterra ${ }^{57}$, que se iniciou com a fundação do Banco da Inglaterra em 1694, o qual assumiu paulatinamente as funções de verdadeiro banco central. Sequencialmente, houve a criação de uma rede de bancos que propiciou a circulação de capitais, além de facilitar os investimentos (coleta da poupança popular), com atividade principal voltada para o financiamento do comércio, da nova agricultura e da indústria em virtude do aumento da disponibilidade de créditos.

Inaugura-se, assim, na cronologia da história mundial, a Idade Contemporânea, marcada por uma economia capitalista em constante mudança em virtude das constantes inovações tecnológicas, que impulsionam, por sua vez, o progresso nos processos produtivos e nos modos de organização, tal como o ocorrido na Revolução Industrial ocorrida no final do Século XVIII na Inglaterra, sendo que a economia, sob a

\footnotetext{
56 “A relação inverte-se no século seguinte, porque a indústria permitirá, por seu turno, relançar a revolução do setor primário. Os progressos de produtividade obtidos por máquinas agrícolas cada vez mais aperfeiçoadas e, posteriormente, a subida dos rendimentos graças aos adubos químicos permitirão reduzir cada vez mais a população camponesa, prosseguir o êxodo rural e, finalmente, a industrialização." (BRASSEUL, Jacques. História Econômica do Mundo: Das Origens aos Subprimes. $2^{\mathrm{a}}$ edição. Lisboa: Edições Texto \& Grafia, 2010, p. 128)

${ }^{57}$ Idem, ibidem, p. 150 - 151.
} 
ótica dos fisiocratas, passou a ser vista como uma ordem natural impregnada por princípios típicos do liberalismo econômico ${ }^{58}$, em substituição ao mercantilismo até então em voga.

As companhias de comércio, no Século XVIII, entraram em franco declínio, visto que o comércio tornou-se multilateral e, assim, houve a quintuplicação das exportações destinadas ao comércio fracionado, enquanto que a produção industrial apresentou um aumento de apenas $50 \%$ (cinquenta por cento).

Somente com a Revolução Industrial ocorrida em meados do Século XVIII, o capital passa a ser investido diretamente na atividade produtiva, de forma que a empresa passa a ser vista como unidade típica de produção. Observe-se que, na Antiguidade, a produção era destinada ao consumo próprio e somente o excedente era objeto de escambo. Já, na Idade Média, a produção pelos artesãos era feita apenas sob encomenda.

A antiga indústria inglesa tinha uma produção tipicamente familiar e dependente do mercador, que comprava a produção familiar para vendê-la na cidade, sujeitando o fabricante ao domínio do mercador, que lhe adiantava fundos, produtos brutos e utensílios para a produção dos manufaturados. Contudo, com a Revolução Industrial, as empresas passaram a concentrar um volume de produção maior voltado para a exportação, o que foi possibilitado pela divisão do trabalho e consequente controle direto dos trabalhadores pelo empreendedor, pela mecanização da produção que utilizava uma nova fonte de energia, o carvão, bem como com a eliminação do mercador.

Desse modo, o empreendedor passou controlar também o fluxo de consumo, o que lhe permitia manter uma produção regular, passando a existir uma clara distinção entre a unidade de produção e a unidade de consumo, esta representada fundamentalmente pelo lar, cessando a confusão que havia anteriormente entre aquelas unidades. Assim, inicia-se um período em que as fábricas apresentavam uma organização mais racional, procuravam instalar-se nas cidades e não mais próximas de rios e florestas, o que lhes

\footnotetext{
58 "Não importa se a interpretação de cada qual é ou não carregada de conotação religiosa; todos aceitam a existência de uma ordem natural subjacente à sociedade e à economia. Se ela existe, os homens em sociedade estão sujeitos a leis naturais do mesmo modo em que na natureza física os fenômenos submetemse a leis físicas. Os fisiocratas acreditam que a produção e a distribuição de bens são efetuadas de acordo com leis fixas da natureza e que os problemas de distribuição devem ser lidados como se enfrentam os problemas da Física." (FEIJÓ, Ricardo. História do Pensamento Econômico. 2.a edição. São Paulo: Atlas, 2007, p. 88)
} 
permitia auferir uma economia nos transportes, além do fácil acesso à mão de obra que se deslocou para as cidades a partir da Revolução Agrícola que precedeu a Revolução Industrial.

Nesta época, ainda predominavam as pequenas empresas, situação que perdurou por boa parte do Século XIX, quando, então, surgiram as grandes empresas mecanizadas, o que foi possibilitado pelo progresso técnico constante a partir de 1760 que, por sua vez, permitiu a existência de uma estabilidade técnica.

$\mathrm{Na}$ época da Revolução Industrial, a economia de mercado começou a atingir seu ápice com a monetarização dos fatores de produção e com a generalização das relações de mercado, o que foi causado (i) pelo surgimento da terra como fator de produção passível de compra e venda em um mercado, (ii) pelo surgimento do trabalho como fator de produção passível de permuta em substituição das relações hierárquicas feudais e (iii) pelo afluxo de metais preciosos decorrentes dos Grandes Descobrimentos, que propiciaram o aumento dos lucros e a intensificação do comércio e da indústria.

Justamente nesta época, o comércio e a indústria apresentavam uma evolução ao darem início à interligação dos mercados, o que demandou o investimento de capitais vultosos em empreendimentos, época em que as companhias passaram a ser consideradas como representantes do modelo estratégico ideal para o desenvolvimento da empresa e, assim, faziram frente à demanda de produção em grande escala, visto que a interligação dos mercados fez surgir a necessidade de haver produção constante em grande escala para satisfazer as necessidades dos mercados.

Nesta segunda fase iniciada no Século XVIII, a empresa passou a ser vista como uma organização produtiva hierarquizada, cuja produção era destinada ao mercado, mas que, ainda, envolvia somente os interesses do empresário e dos empregados. Nesta fase, o empresário acumulava o exercício das três funções econômicas empresariais, quais sejam: (i) a função de empreendedor, enquanto criador da empresa e principal agente voltado à sua expansão; (ii) a função de chefe da estrutura hierárquica da empresa, ao gerir a empresa na qualidade de chefe máximo dentro de uma organização administrativa hierárquica; e (iii) a função de investidor, pois assumia os riscos do empreendimento. 
Assim, percebe-se que o Estado, que era o sócio dominante na primeira fase, deixa de participar da composição societária nesta segunda fase, mas, ainda, exercia um controle ostensivo ao exigir a prévia autorização estatal para a constituição das sociedades anônimas, que tinham sua atuação restrita às áreas de interesse geral.

Após a Revolução Industrial, por volta do Século XIX, inicia-se a terceira fase das sociedades anônimas.

No Século XIX, o modo de produção industrial apresentava-se com maior dimensão, ou seja, requeria grandes investimentos, produção em massa e fabricação em série, o que era possibilitado com o aumento da utilização da ciência associada às técnicas industriais, permitindo o desenvolvimento de tecnologias em rede. Uma primeira consequência é vista no fato das novas tecnologias exigirem um maior volume de produção que se mostrava compatível com as grandes empresas, além de haver uma maior compatibilidade do modelo da grande empresa com o acesso ao mercado financeiro, com as novas formas de distribuição dos produtos e com a nova forma de organização do trabalho.

Ademais, o mercado estava cada vez mais exigindo uma maior mobilização de capital em virtude da concorrência instaurada entre os empresários no ambiente de uma economia de mercado, de modo que passou a ser necessário o investimento de capitais vultosos para expandir a empresa e fazer frente a grandes empreendimentos indispensáveis para a satisfação das necessidades mercadológicas, o que provocou uma rápida expansão da Revolução Industrial entre os anos de 1815 e 1914.

Nesta época, tivemos o início da formação do Direito das Companhias, momento em que este modelo jurídico de sociedade volta-se a empresas de grande porte e o diploma legal de maior relevância, naquela época, foi o Código Comercial Francês de 1807, que, segundo Tulio Ascarelli ${ }^{59}$, marcou o fim da segunda fase da história do Direito Mercantil. A legislação codificada francesa estava fundada basicamente nos seguintes pilares: (i) direito de propriedade e contrato, sendo este o meio de aquisição da propriedade; (ii) regulação da economia de modo objetivo, sem a concessão de privilégios; (iii) circulação da propriedade privada por meio do instrumento contratual; (iv) livre

${ }_{59}$ ASCARELLI, Tulio. Iniciação ao Estudo do Direito Mercantil. Sorocaba: Minelli, 2007, p. 86. 
iniciativa e tutela da propriedade privada; e (v) igualdade jurídica e recusa das desigualdades econômicas.

Na denominada terceira fase do Direito Mercantil (segundo a classificação de Tulio Ascarelli), há a prevalência da liberdade de iniciativa, além da aplicação objetiva das normas mercantis, ou seja, aplicação das normas jurídicas em harmonia com o princípio da igualdade jurídica dos cidadãos, bem como com a soberania e unidade do Estado. Vigorou, neste período, a ideia da codificação nos moldes dos códigos napoleônicos que se impôs aos demais países, com ressalva aos países de origem anglosaxã, que apenas adotaram a lei como regulamento especial em relação ao direito produzido pelos precedentes jurisprudenciais.

A legislação de Direito Mercantil, nesta terceira fase, é orientada por alguns fundamentos, quais sejam, (i) a observância do interesse do consumidor, (ii) a liberdade de concorrência, (iii) o grande desenvolvimento dos intercâmbios internacionais, (iv) a contraposição do poder econômico ao poder público, $(v)$ o sistema econômico passa a ser considerado como sendo autorregulador, por meio do mecanismo da livre concorrência no mercado, mecanismo este que também se destinava a evitar a concentração do poder econômico e a promover o desenvolvimento econômico, (vi) os direitos de propriedade intelectual (propriedade industrial e direitos autorais) passaram a ser considerados como sendo vitais para a identificação do produto, deixando de ser mero meio de controle da qualidade dos produtos, (vii) a tutela do crédito, (viii) a disciplina objetiva dos atos do comércio e (ix) a lei passou a ser considerada uma garantia do desenvolvimento das atividades econômicas.

Além disso, houve uma mudança na concepção do Direito Mercantil, que deixa de ser o direito regulamentador das atividades dos artesãos e passou a ser o direito regulamentador da atividade industrial e dos produtos industriais, com a inserção do conceito de empresa. Contudo, ainda na segunda metade do Século XIX, o princípio da limitação da responsabilidade dos acionistas ainda era visto com certa desconfiança, o que justifica a necessária autorização prévia para constituição da sociedade por ações.

Este período que se iniciava era um momento de transformações no âmbito do Direito Mercantil, sendo que, em 1848, a legislação cambiária alemã instituiu 
pioneiramente a desvinculação da letra de câmbio da relação jurídica subjacente, de modo que a letra de câmbio deixou de ser um instrumento conexo ao contrato de câmbio para ser um instrumento geral de crédito que permitia sua mobilização, o que se mostrava em direta conexão com o desenvolvimento da intermediação do crédito por instituições financeiras, que realizavam as operações de descontos das letras de câmbio e, assim, permitiam a mobilização do crédito pelos comerciantes e industriais, além de direcionar o crédito para os financiamentos de curto prazo do ciclo econômico.

Na França, a partir de 1863, a constituição das sociedades por ações passou a ser livre, desde que fossem preenchidos os requisitos legais, o que, segundo Tulio Ascarelli, levou à multiplicação da constituição das sociedades por ações, enquanto “instrumento máximo da industrialização, e encontrando assim o fundamento da responsabilidade limitada do acionista (cuja contrapartida está num sistema de publicidade e responsabilidade) na mesma redução de custos (e por isso, de preços) que esta pode provocar facilitando a industrialização."60

Assim, nas legislações sobre sociedades mercantis, constata-se uma constante preocupação em permitir a maior captação da poupança pública, em possibilitar a circulação das ações representativas das participações nas sociedades e em proporcionar uma maior proteção do público subscritor e adquirente das ações emitidas ou vendidas.

No âmbito econômico, a rápida expansão da Revolução Industrial levou à sua segunda fase a partir de 1830, conhecida por fase tecnológica, em que, concomitantemente com as mudanças do Direito Mercantil, que foram acima indicadas, houve o progresso das máquinas de alta pressão, que exigiam o investimento de capital técnico mais forte e que era detido somente pelas grandes empresas, o que deu origem a uma nova fase do capitalismo, marcado pelas grandes unidades de produção e pelo desenvolvimento dos bancos, das bolsas e das operações financeiras de um modo geral, proporcionando um alargamento do mercado, que resultou na economia de larga escala, bem como no aumento da circulação de capitais e das trocas de bens e serviços, ou seja, do comércio em geral, de modo que as estruturas econômicas evoluíram para as estruturas

${ }^{60}$ ASCARELLI, Tulio. Iniciação ao Estudo do Direito Mercantil. Sorocaba: Minelli, 2007, p. 94. 
com as características das atuais sociedades desenvolvidas economicamente, especialmente sob o aspecto do livre câmbio em detrimento do protecionismo.

Nesta segunda fase da Revolução Industrial, há uma verdadeira interpenetração da ciência e da tecnologia dentro da empresa, o que obviamente implicou em mudanças na organização econômica, justamente para permitir a concretização do potencial tecnológico atingido com a ajuda da ciência.

Na Europa como um todo, no período compreendido entre 1815 e 1914, há o surgimento da indústria moderna, o que foi fomentado $(\boldsymbol{i})$ pela existência de jazidas de ferro ou de carvão, (ii) pela presença de indústrias tradicionais, (iii) pela ausência de regulação corporativista ou controle estatal e (iv) pela proximidade de grande porto que propiciou os efeitos industrializantes decorrentes do comércio internacional, sem prejuízo das intensas modificações econômico-sociais.

$\mathrm{Na}$ França, por exemplo, a partir de 1840, surgem os primeiros bancos de negócios, que se especializaram em operações de crédito de longo prazo e em operações de investimentos industriais, bem como os bancos de depósitos destinados à captação da poupança popular e à realização de operações de crédito de curto prazo.

No final do Século XIX, iniciou-se uma grande depressão econômica, que se expandiu para todos os países por meio da diminuição das trocas comerciais e da redução da movimentação de capitais, o que causou uma redução no ritmo de crescimento e levou as empresas a buscarem um aumento de produtividade com a adoção de uma maior mecanização do processo produtivo, bem como uma limitação da diminuição dos lucros ao buscarem a concentração empresarial.

Segundo, Jacques Brasseul, a crise ocorrida no final do século XIX, foi uma crise que marcou a passagem do capitalismo concorrencial, que foi marcado pela flexibilidade dos salários e dos preços, para o capitalismo monopolista do século XX, este marcado "pela produção em massa, por rápidos ganhos de produtividade, por um alargamento do consumo e pela rigidez dos salários e dos preços em baixa"61, bem como

${ }^{61}$ BRASSEUL, Jacques. História Econômica do Mundo: Das Origens aos Subprimes. $2^{a}$ edição. Lisboa: Edições Texto \& Grafia, 2010, p. 203. 
pela aumento da especialização, podendo-se, inclusive, falar em hiperespecialização, aumento do nível de vida, aumento da complexidade social e das trocas também, além do desenvolvimento do setor terciário que se tornou dominante.

Neste período, outros países com potenciais econômicos começam a alcançar o mesmo nível dos países europeus, tais como Estados Unidos da América, Japão e Rússia, além do desenvolvimento mais periférico, tal como o ocorrido na América Latina, na Turquia, no Egito etc. Merece destaque o Japão por se tratar de país fora do foco eurocêntrico.

O Japão, em 1603, era governado pela família Tokugawa que isolou o país de influências externas, ao estabelecer um sistema feudal similar ao sistema feudal ocidental, no qual famílias controlavam os camponeses e os burgueses das cidades que se encontravam organizados em corporações. Neste período, havia um equilíbrio entre o mercado livre e o governo forte para garantia dos contratos. As cidades apresentavam uma grande concentração das trocas monetárias, das operações de crédito e do mercado a prazo para a comercialização do arroz.

Em 1868, com o fim do regime do Shogun, o imperador foi restabelecido nas suas funções de chefe de Estado, sendo que a era Meiji findou em 1912 com a morte do imperador, o que levou ao poder uma elite oligárquica, dando início a um período marcado pela centralização do poder, pelo fim do feudalismo e pelo restabelecimento de uma liberdade de circulação interna e externa. As obras de infraestruturas são financiadas por meio de uma taxa fundiária cobrada dos agricultores, a qual não dependia da produção, mas incentivava os agricultores a retirarem o máximo de proveito da terra. A referida taxa também acabou financiando a industrialização, de modo que a partir de 1880 tem-se o início da formação dos zaibatsus, que constituíam grandes grupos empresariais que representavam, aproximadamente, um terço da produção nacional japonesa.

No Japão, o Estado, nos anos de 1880, assumiu um papel central na planificação econômica, especialmente em relação à infraestrutura às indústrias pesadas, sendo que o setor secundário formado pelas indústrias leves estava fundado na substituição das importações. O Japão modernizou-se com a compra das técnicas estrangeiras ocidentais, bem como com a formação de especialistas no exterior, o que denotava a 
determinação do povo japonês, o instinto de assimilação fácil e a grande capacidade de organização, o que aliado à liberalização política, levou a um rápido crescimento econômico após a era Meiji, com as exportações favorecidas pela $1^{\text {a }}$ Guerra Mundial.

Na Europa, o final do Século XIX foi marcado pela expansão imperialista fundada no avanço técnico, econômico e militar dos países europeus, época esta marcada pelas técnicas modernas, pela eficácia econômica do mercado e da concorrência, pelas instituições jurídicas e políticas favoráveis ao desenvolvimento, bem como por conceitos típicos do Iluminismo, tais como liberdade, direito dos povos e democracia.

Como dito acima, o final do Século XIX e o início do Século XX são marcados por um movimento concentracionista das empresas, seja em relação às grandes empresas atuantes nas novas atividades (isto é, automobilística e petrolífera, que se situam no centro da economia), seja em relação às pequenas e médias empresas centradas nas atividades econômicas tradicionais, de forma que se pode verificar uma transformação do capitalismo de pequenas unidades industriais para um capitalismo monopolista ou oligopolista, o que, segundo Jacques Brasseul ${ }^{62}$, é explicado (i) pela tentativa das empresas buscarem uma forma de evitar os efeitos da concorrência sobre os seus lucros, (ii) pela busca da minimização dos altos investimentos exigidos para a adoção de novas técnicas já adotadas pelas novas indústrias, (iii) pela necessidade de implantar a produção em larga escala, não só para satisfazer a demanda, mas, sobretudo, para reduzir os custos de produção e financiar a pesquisa, (iv) pela necessidade de enfrentar a concorrência de empresas estrangeiras com atuação no mercado mundial e, assim, estabelecer uma rede internacional de vendas.

Este movimento de concentração é acompanhado pela introdução de uma organização e gestão empresariais mais racionais, científicas, além do aparecimento de uma nova classe de dirigentes empresariais, que se diferenciam por serem administradores profissionais e não mais acionistas cumulativamente, o que propicia a tomada de decisões técnicas que visam ao interesse da empresa, além de incutir uma gestão de longo prazo, como explica Jacques Brasseul:

${ }^{62}$ BRASSEUL, Jacques. História Econômica do Mundo: Das Origens aos Subprimes. $2^{\mathrm{a}}$ edição. Lisboa: Edições Texto \& Grafia, 2010, p. 249 - 250. 
"Uma outra transformação importante é o aparecimento de uma nova classe de dirigentes profissionais - os gerentes -, que já não são proprietários. A separação entre acionistas e dirigentes introduz uma visão a longo prazo na gestão. Visando acima de tudo o interesse da empresa, os gestores tomarão as decisões cruciais em matéria de investimento e de estratégia empresarial de modo cada vez mais independente dos acionistas, demasiado dispersos para exercerem controlo (sic)."63

A sociedade anônima passa, então, a ser vista como um modelo jurídico hábil para captar a poupança de um grande número de pessoas com o fim de investir na produção e, assim, permitir a expansão da empresa ${ }^{64}$. É, também, nesta fase que temos os delineamentos da sociedade empresária democrática, ou seja, a formação de uma estrutura interna da sociedade anônima com órgãos destinados à deliberação, à execução e à fiscalização, além de se dar o início à liberdade de constituição das sociedades anônimas.

A partir desse momento, as três funções econômicas do empresário deixam de ser atribuição exclusiva e cumulativa à posição do empresário e passam a ser exercidas de maneira descentralizada e dentro da estrutura interna administrativa hierarquizada, de modo que os fundadores continuam detendo o exercício da função de empreendedor, enquanto que a função de administrar passa a ser exercida especificamente por administradores e a função de investidor passa a ser pulverizada no mercado de valores mobiliários, de modo a dividir-se a responsabilidade dos riscos do empreendimento com os demais acionistas. Inicia-se, assim, a flagrante dissociação entre a gestão da empresa e os riscos assumidos pelos investidores, como bem indicou Tulio Ascarelli:

“À participação do acionista se contraporá o 'controle' do grupo que logra concentrar a maioria dos votos nas assembléias; a uma estrutura econômica, baseada normalmente na coincidência entre risco e gestão, se substituirá uma dissociação sempre mais profunda, quanto mais se

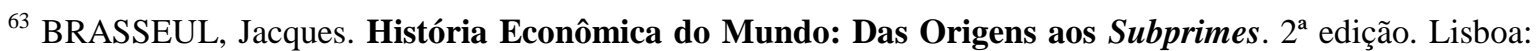
Edições Texto \& Grafia, 2010, p. 250 - 251.

64 "O estatuto de sociedade anônima permite juntar enormes capitais necessários às novas atividades industriais (...) As ações e obrigações tornam-se desde então o meio de financiamento essencial das empresas. As bolsas de valores desenvolvem-se como principal mercado desses títulos." (Idem, ibidem, p. 200) 
difundam as ações, e a difusão da propriedade se conciliará, como poderia se dizer, com uma concentração no controle da riqueza." 65

A partir do final do Século XIX e início do Século XX, os países europeus apresentaram um grande aumento em suas relações econômicas internacionais, com um crescimento alto do fluxo migratório de pessoas, de trocas de bens e serviços e do fluxo de capitais, sendo que este fluxo atingiu um volume sem precedentes e visava ao financiamento de infraestrutura, de atividades extrativas, de indústrias de transformação, de instituições financeiras, de companhias seguradoras e das atividades de exploração agrícola.

Segundo Jacques Brasseul ${ }^{66}$, a posição centralista dos países europeus no fluxo de capitais, posicionando-os como credores, justificava-se simplesmente porque os mesmos passaram pelo processo de industrialização antes de outros países, o que fundamentava o excedente de capital que era destinado ao suprimento da escassez de capital em outros países. Enquanto o endividamento permitiu a alguns países a aceleração do desenvolvimento econômico, ao utilizar o capital externo para investimento em infraestrutura e na formação de indústrias, de modo a permitir a criação de uma capacidade produtiva e de um fluxo exportador, culminando com a quitação da dívida, para outros países o endividamento aprofundou o atraso econômico, em razão da existência de entraves estruturais e institucionais, isto é, em razão do desperdício de capitais e de realização de investimentos duvidosos, tornando-os mais dependentes, culminando com crises de insolvabilidade.

Já no final do Século XX, a situação encontrada é de grande abertura em termos de comércio internacional, tendo havido um progresso nas trocas internacionais e até na integração entre os países, com a celebração de acordos multilaterais. No âmbito financeiro, após a adoção do padrão-ouro como padrão do sistema monetário internacional,

${ }^{65}$ ASCARELLI, Tulio. Iniciação ao Estudo do Direito Mercantil. Sorocaba: Minelli, 2007, p. 95.

${ }^{66}$ BRASSEUL, Jacques. História Econômica do Mundo: Das Origens aos Subprimes. $2^{\mathrm{a}}$ edição. Lisboa: Edições Texto \& Grafia, 2010, p. 256-257. 
o mercado financeiro encontrava-se mais integrado ${ }^{67}$, o mercado de trabalho também diante da maior mobilidade da mão de obra.

Com o advento da $1^{\text {a }}$ Guerra Mundial, o padrão-ouro deixou de ser adotado, em favor da adoção do curso forçado das moedas locais, e a Europa sofreu uma grave crise econômica, de tal modo que o produto nacional bruto dos países europeus em 1918 era aproximadamente 30\% (trinta por cento) do produto nacional bruto de 1914, sendo que somente em 1924 a produção europeia voltou ao nível anterior à $1^{\text {a }}$ Guerra Mundial.

Assim, no momento em que a economia atingiu os níveis prévios à $1^{\mathrm{a}}$ Guerra Mundial, outra grave crise iniciada nos Estados Unidos da América atingiu a economia mundial em 1929, cujo rápido contágio justificou-se pelo fato dos Estados Unidos da América representarem 42\% (quarenta e dois por cento) da produção mundial, enquanto que a França, a Alemanha e a Grã-Bretanha representavam conjuntamente $28 \%$ (vinte e oito por cento) da produção mundial. Além disso, as transações realizadas pelos Estados Unidos representavam $12 \%$ (doze por cento) do comércio internacional, sem se considerar que importavam até $40 \%$ (quarenta por cento) das matérias primas do mundo ${ }^{68}$.

Nos Estados Unidos, a valorização da Bolsa de Valores não parava de subir, chegando a atingir, em um trimestre de 1929, uma valorização maior do que a ocorrida no curso de 1928, o que atraía o investimento de todas as pessoas pertencentes às diversas classes sociais, conforme relada Jacques Brasseul:

"A Bolsa não parava de subir, atraindo todas as categorias sociais, do financeiro e do especulador até às pessoas mais modestas. Os títulos dos setores do futuro (automóvel, aeronáutica, distribuição moderna e, sobretudo, rádio) são os mais procurados. Segundo uma sondagem do Senado, estima-se em um milhão e meio o número de compradores, ou seja, 5\% dos agregados familiares. Nessa década, a média de cotações tinha multiplicado por vinte. Aquando da vitória de Hoover nas eleições

\footnotetext{
67 “Apesar de tudo, os mercados financeiros estavam mais integrados em 1900 do que hoje. Em 1900-1910, os investimentos diretos no estrangeiro representavam aproximadamente o equivalente ao investimento interno, enquanto nos anos 1990 representavam menos de 10\% nos países desenvolvidos." (BRASSEUL, Jacques. História Econômica do Mundo: Das Origens aos Subprimes. $2^{a}$ edição. Lisboa: Edições Texto \& Grafia, 2010, p. 261)

${ }^{68}$ Idem, ibidem, p. 310.
} 
de novembro, acelera a subida. O verão de 1929 conhece ainda uma irrupção, as cotações aumentam mais num trimestre do que durante os doze meses de 1928, ano da subida sem precedentes no qual elas tinham duplicado.

Depois, subitamente, sem que se saiba ainda a razão imediata, em alguns dias, tudo se desmoronou, como uma barragem que cedesse bruscamente. Em 24 horas, a subida de um ano foi anulada; em algumas semanas, desapareceram trinta mil milhões de 'riquezas'. Milhões de pessoas que acreditavam ter enriquecido graças à Bolsa ficaram arruinadas. Na 'quinta feira negra', 24 de outubro de 1929, e na terça, 29, duas ondas de pânico levaram a vendas maciças e a uma descida das cotações sem precedentes. Os títulos das sociedades de investimento caíam abaixo de 1 dólar, quando ultrapassavam 100 dólares antes da crise, ou já nem se vendiam, fosse qual fosse o preço...Seguiram-se as bolsas de comércio (matérias primas), arrastando para a crise os países produtores." 69

Contudo, somente a partir de 1930 os efeitos da crise iniciada nos Estados Unidos é sentida no âmbito mundial com a queda na produção, falências de empresas e aumento do desemprego ${ }^{70}$, de modo que a crise na bolsa de valores gerou a perda de confiança dos investidores que, consequentemente, precipitam-se em retirar seus recursos depositados nos bancos que, obviamente, não conseguem fazer frente à "corrida bancária" e acabam por falir, dando origem a uma crise bancária e desencadeando uma crise de crédito, provocando uma queda no consumo, nos investimentos e na produção, dando causa, também, a uma crise econômica.

${ }^{69}$ BRASSEUL, Jacques. História Econômica do Mundo: Das Origens aos Subprimes. $2^{\text {a }}$ edição. Lisboa: Edições Texto \& Grafia, 2010, p. 311.

70 "A crise bolsista transforma-se em crise da economia real, depois em depressão duradoura, por efeito da perda da confiança que se repercute no investimento, do pânico que provoca a falência de bancos, da redução do consumo ligada ao empobrecimento dos detentores de títulos, e das dificuldades de tesouraria das empresas afetadas pela descida das cotações. As pessoas com poupanças precipitam-se para retirar o dinheiro dos bancos os quais não podem fazer face a isso, e a crise bolsista transforma-se em crise bancária. As múltiplas falências de bancos provocam uma redução maciça do crédito, que, por seu turno, causa uma queda do consumo, do investimento e da produção. Aí está a crise econômica com o seu cortejo de desemprego, descida de preços e de salários e encerramento de empresas." (Idem, ibidem, p. 312) 
Esta crise de 1929 teve como uma de suas consequências a divisão do sistema monetária e comercial mundial em blocos regionais autônomos, além da fixação de câmbios flutuantes no âmbito mundial. Além disso, houve uma crise mundial de pagamentos, de forma que a redução das divisas causa uma redução das importações de manufaturados, mas, na América Latina, causou o início do processo de industrialização por substituição das importações, bem como um aumento, no mundo, dos rendimentos e da produtividade agrícola em virtude dos progressos técnicos.

Desse modo, os países passaram a substituir as políticas deflacionistas por uma política de relançamento, tal como, por exemplo, a Suécia que, em 1932, lançou a social democracia marcada pelo respeito às empresas privadas e à economia de mercado, bem como pela redistribuição fiscal e pela política de serviços sociais. Logo, as políticas adotadas no entre guerras visavam (i) à concorrência saudável, (ii) ao intervencionismo estatal no domínio econômico para garantir a segurança e proteção social dos cidadãos e (iii) à regulação global no nível macroeconômico, sob a ótica do capitalismo dirigido.

Contudo, a $2^{\mathrm{a}}$ Guerra Mundial, além das consequências humanitárias, fez com que a Europa perdesse a sua supremacia mundial em favor dos Estados Unidos e da extinta União Soviética e, ainda, mais tarde da China também, constituindo, estes três países, as novas superpotências econômicas e políticas, representando o dualismo concorrente de dois sistemas econômicos por quase meio século: o capitalismo de mercado e o socialismo planificado.

No pós-guerra, o Japão, que tinha um regime militar, autoritário e brutal, adotou uma democracia pacifista e consolidada. No âmbito econômico, o Japão adotou uma economia capitalista de mercado que se diferenciava das demais economias capitalistas de mercado pela organização das grandes empresas e pela importância das relações entre empresa e a função diretiva do Estado. Além disso, o regime de organização empresarial era um regime protegido e fechado aos capitais estrangeiros, não obstante as empresas fossem privadas e os preços, livres, regime este dominado pelo Estado, pelos grandes grupos empresariais e pelas casas de comércio.

A industrialização foi retomada após a $2^{\mathrm{a}}$ Guerra Mundial, não no sentido de adotar a especialização internacional, mas, sim, adotando indústrias menos adaptadas ao 
país (como, por exemplo, as indústrias dos ramos da siderurgia, refinaria, petroquímica, automobilística, mecânica industrial, eletrônica e informática) e que, por isso, requeriam um grande investimento de capital e tecnologia, mas eram indústrias cuja rentabilidade era alta, o progresso técnico era obtido de modo rápido e a produtividade aumentava rapidamente.

O Século XX é marcado também pela dominação dos Estados Unidos da América, que associaram os negócios, a ciência e a política, coordenando a ação conjunta dos diferentes saberes, sem que houvesse uma estrita divisão do trabalho, tal como ocorria na Europa. A partir de 1920, vislumbra-se a intensificação do mercado de consumo, que se consolidou após 1945.

Nas primeiras décadas do Século XXI, os Estados Unidos mantiveram sua supremacia econômica e a hegemonia política, especialmente com a derrocada do comunismo, que foi simbolicamente marcada pela Queda do Muro de Berlim, momento em que diversos países do leste europeu iniciam uma transição para a economia de mercado com altos investimentos de grandes empresas ocidentais, devendo-se ressaltar que estes países, em fase de transição, apresentavam um fraco plano institucional, visto que (i) não tinham gestão moderna nas empresas, (ii) inexistia mercado de valores mobiliários e de câmbio, (iii) inexistia sistema bancário, (iv) não possuíam mercado de fatores de produção, (v) não havia títulos de propriedade de terras, (vi) inexistiam regras sobre compra e venda de ativos, ações, obrigações ou divisas, (vii) não havia moeda escritural, sistema de hipoteca e crédito bancário.

Na América Latina, não se constatou idêntico desenvolvimento tal como o ocorrido na América do Norte, seja em razão da dominação a que os países da América Latina sujeitaram-se, seja em virtude da herança burocrática institucional herdada dos países ibéricos. Já, no Século XX, os países da América Latina progrediram bastante em termos de desenvolvimento da capacidade produtiva, primordialmente em razão da substituição das importações no pós-guerra, proporcionando a criação de poderosas indústrias e mudanças institucionais e sociais importantes, tendo, o Estado, exercido papel fundamental neste desenvolvimento industrial. 
Este é um período marcado pela assunção estatal da administração do capitalismo, de modo que existe produção dos setores básicos, as infraestruturas são criadas, são adotados mecanismos de redistribuição e proteção social, os investimentos são orientados, há o controle do câmbio e a organização e controle do crédito. Acrescente-se, ainda, que desde 1980 está em curso o que Jacques Brasseul denomina de "a terceira revolução tecnológica", que é marcada pela revolução da comunicação proporcionada pela informática e pela revolução conduzida pela biotecnologia, dando origem, portanto, à nova economia, que permite a existência de um mercado de escala infinita, visto que a comercialização dos produtos pode atingir a transnacionalidade com muita facilidade, especialmente impulsionada pelo comércio eletrônico, o que leva as empresas a obter ganhos com a alta produtividade.

Assim, esta terceira fase da sociedade por ações culminou com o surgimento da macroempresa, que assumiu uma responsabilidade social e uma função social, não mais se limitando aos interesses do empresário e dos empregados, mas, sim, abarcando os interesses da comunidade de sua atuação, dos demais acionistas, mesmo os meros investidores, momento em que se conferiu uma proteção aos minoritários ${ }^{71}$ como forma de controlar os desmandos do acionista controlador.

\footnotetext{
${ }^{71}$ Deve-se observar que, nos dias atuais, a referência à figura do acionista minoritário remete à figura do acionista investidor institucional, ou seja, a fundos de investimentos de relevância no mercado, que possuem uma assessoria técnica mercadológica e uma assessoria jurídica de excelente especialização. Conforme Gerald F. Davis e de Tracy A. Thompson: "Who owns and controls large corporations in the United States has changed significantly over the course of the twentieth century (...)Where corporate managers once faced a dispersed and relatively powerless set of stockholders, they now confront an increasingly organized social movement of fund trustees and advisors that share a common ideology of shareholder activism as well as the power to vote a substantial chunk of the largest firms' equity (...) Where shareholders were once disenfranchised outsiders in corporate governance, institutional investors are now members of the polity, and their concerns are routinely taken into account in decision-making processes in firms and in governmental policy making." (DAVIS, Gerald F. \& THOMPSON, Tracy A.. A Social Movement Perspective on Corporate Control. In: Administrative Science Quarterly, v. 39, $\mathrm{n}^{\text {o }}$ 1, 1994, p. 141. Disponível em <http://webuser.bus.umich.edu/gfdavis/Papers/A\%20Social\%20Movement.pdf〉. Acesso em 09.06.2013.) Tradução livre: “Quem detém a propriedade e controla as grandes companhias nos Estados Unidos mudou significativamente no curso do século XX (...) Nas companhias em que os administradores, então, deparavam-se com um conjunto de acionistas dispersos e destituídos de poder, agora encontram um crescente movimento social organizado de administradores de fundos de investimentos e conselheiros que compartilham uma ideologia comum ao ativismo dos acionistas, assim como possuem o poder de votar com uma substancial parcela das ações das grandes empresas (...) No lugar dos acionistas que eram anteriormente estranhos ao governo da empresa destituído do poder de voto, agora encontram-se os investidores institucionais enquanto membros do sistema de governo empresarial, cujas preocupações são rotineiramente levadas em consideração nos processos de formação das decisões nas empresas e na tomada de decisões."
} 
Em alguns países, especialmente nos Estados Unidos e no Reino Unido, as sociedades anônimas são marcadas pela alta pulverização acionária, enquanto outros países são marcados pela extrema concentração do poder de controle nas mãos da figura do acionista controlador, variando entre o poder de controle totalitário e majoritário.

De qualquer modo, constata-se, atualmente, que o modo de gestão das empresas mudou, no qual os acionistas, especialmente após a ascensão dos grandes acionistas coletivos, ditam as diretrizes da empresa, com especial preocupação com a rentabilidade, com os meios de fiscalização da administração, não se podendo olvidar que, na atual internacionalização (ou globalização) econômica, como bem ressaltou Jacques Brasseul, as empresas encontram-se no cerne deste sistema econômico mundial, além do comércio internacional em 2008 representar 33\% (trinta e três por cento) da produção industrial, contra 24\% (vinte e quatro por cento) em 1998 e 9\% (nove por cento) em 1980:

“A globalização econômica pode ser ilustrada com o facto de o comércio internacional representa em 2008 um terço da produção mundial, contra $24 \%$ em 1998 e 9\% em 1980. As empresas multinacionais estão no cerne dessa evolução que organismos internacionais como o FMI e a OMC tentam regular como podem (...) Elas são os motores do sistema integrado de produção mundial. As mil maiores empresas do mundo representam 4/5 da produção industrial mundial; em certos países, como a Irlanda, representam, o essencial da atividade (2/3 da produção e metade do emprego, neste caso). Entre as cem entidades mais importantes à escala mundial, quarenta e cinco são empresas e não países, comparando o volume de negócios e os PIB." ${ }^{, 72}$

Feita uma breve incursão na evolução histórica da economia e das sociedades por ações no mundo, é imprescindível que se faça o mesmo voltando-se para a evolução da economia e da sociedade anônima no Brasil.

A ocupação das terras americanas teve início no momento em que o comércio com o oriente, na época dos grandes descobrimentos, sofria dificuldades em

${ }^{72}$ BRASSEUL, Jacques. História Econômica do Mundo: Das Origens aos Subprimes. $2^{\mathrm{a}}$ edição. Lisboa: Edições Texto \& Grafia, 2010, p. 407. 
razão da invasão turca no Século XV, momento em que Portugal e Espanha veem-se obrigados a explorar novas terras. Em relação ao Brasil, Portugal explorou as terras brasileiras de modo diferente, ou seja, não visou primordialmente à atividade extrativa de metais, mas, sim, à exploração agrícola por meio de investimento de capitais, como forma de manter um fluxo constante de bens ao mercado europeu.

Nesta época, em Portugal, havia uma associação econômica da burguesia comerciante à Coroa Portuguesa, a qual, por sua vez, dominava os burgueses na exploração colonial do Brasil, que era voltada para as trocas e para o comércio colonial, associação esta que resultou em ótimos resultados financeiros e no aumento do poder econômico da Coroa Portuguesa, que se apresentava como elo principal entre as novas terras exploradas e os países europeus com um ativo comércio de transporte de mercadorias.

O comércio apresentava-se como uma atividade de monopólio do Estado que, por sua vez, delegava aos particulares por meio da concessão de privilégios, formando um verdadeiro estamento associado ao Estado, dentro de uma concepção de capitalismo politicamente orientado que impedia o surgimento da empresa livre. Segundo Raymundo Faoro $^{73}$, este capitalismo politicamente orientado e dominado pela Coroa Portuguesa, em que esta constituía sua fonte de rendas pela tributação das atividades comerciais e industriais privadas, bem como exercia a mercancia indiretamente, fazia com que os privilégios concedidos consumissem os lucros obtidos, ao serem destinados aos senhores e ao clero, que não eram poupados, portanto, para o financiamento de novos investimentos, decorrendo desta sistemática o atraso na estrutura capitalista do Estado e o enfraquecimento da iniciativa privada.

Desse modo, o próprio Direito Português, que também era aplicado no Brasil Colônia $^{74}$, teve por finalidade primordial servir à organização política, jamais ao comércio, à economia, prevendo a existência de um Estado interventor no âmbito

\footnotetext{
${ }^{73}$ FAORO, Raymundo. Os Donos do Poder. Vol. 1. 10. ${ }^{\text {a }}$ edição. São Paulo: Globo e Publifolha, 2000, p. 66.

74 “Ao aqui chegar, os portugueses encontraram uma população dispersa em várias tribos, chamando esse povo indistintamente de índios. Como é sabido, o estágio evolutivo dos que aqui residiam era comparado ao do período neolítico (desconheciam a escrita, a roda etc.). Adicione-se a isso o fato de não existirem instituições políticas e jurídicas com um mínimo de representatividade. Não houve nem discussão: os portugueses impuseram sem o menor constrangimento o seu sistema jurídico à nova colônia, não restando absolutamente nada dos antigos costumes jurídicos dos indígenas." (MACIEL, José Fabio Rodrigues \& AGUIAR, Renan. História do Direito. 6. a edição. São Paulo: Saraiva, 2013, p. 197)
} 
econômico, dos negócios, do comércio marítimo etc., que modelava a legislação à orientação política dominante, como bem indicou Raymundo Faoro:

“O capitalismo comercial, politicamente orientado, só ele compatível com a organização política estamental, sempre gradativamente burocrática, ajusta a si o direito, limita a ideologia econômica, expandese em monopólios, privilégios e concessões (...) O Brasil, de terra a explorar, converte-se, em três séculos de assimilação, no herdeiro de uma longa história, em cujo seio pulsa a revolução de Avis e a corte de D. Manuel." 75

Assim, a empresa colonizadora tinha nítido caráter capitalista comercial, mas orientado politicamente pela Coroa Portuguesa, que subjugava os interesses puramente econômico-mercantis da iniciativa privada dos comerciantes e, por meio do capital dos comerciantes, exercia a mercancia indiretamente, reservando para si uma parte da produção colonial. Um exemplo desta forma de capitalismo mercantil politicamente orientado é encontrado no sistema das capitanias hereditárias, cujas atividades eram concedidas à iniciativa privada, mas, em contrapartida, a Coroa Portuguesa impunha limites, dirigia e estimulava a iniciativa privada que era totalmente destituída de autonomia, mas sempre voltada ao proveito do comércio europeu, especialmente a empresa agrícola monocultora, cuja produção era voltada à exportação.

Esta será a essência que fundamentará a evolução econômico-social do Brasil Colônia, de modo que "a realidade econômica e social se articulará num complexo político, que governa as praias e atravessa os sertões, por meio do financiamento aos meios de produção, sobretudo de escravo, e dos vínculos aos compradores europeus."76

Nesse ambiente, a Coroa Portuguesa regia materialmente a economia colonial, seja delegando a gestão de monopólios aos particulares (conhecidos por contratadores), que exerciam a gestão do negócio por conta do Poder Público, seja por meio da delegação da gestão econômica de bens o que se materializava pelas concessões e, ainda, também pela constituição de companhias privilegiadas do comércio, as quais

${ }^{75}$ FAORO, Raymundo. Os Donos do Poder. Vol. 1. 10. ${ }^{a}$ edição. São Paulo: Globo e Publifolha, 2000, p. 76.

${ }^{76}$ Idem, ibidem, p. 131. 
possuíam iniciativa pública com preponderante papel do Estado, tais como a Companhia Geral do Comércio do Brasil (fundada em 1649), a Companhia do Maranhão (fundada em 1678), a Companhia Geral do Grão-Pará e Maranhão (fundada em 1755) e Companhia Geral de Pernambuco e Paraíba (fundada em 1759).

Com a crise de rentabilidade da empresa agrícola colonial na segunda metade do Século XVII, tendo em vista que o mercado interno pouco influenciava a exploração colonial voltada para a exportação e cuja renda era remetida para a Metrópole, com o fim de arcar com os gastos de consumo de produtos vindos de outros países europeus, que se encontravam em processo de industrialização, bem como para custear a burocracia aliada da Corte, a Colônia vê-se sem capital acumulado para investir e renovar as suas atividades e a Metrópole, por sua vez, encontra-se sem capital para ampliar a sua atividade industrial a ponto de substituir as manufaturas inglesas. O Século XVIII marcou a articulação da economia colonial e portuguesa à economia inglesa, bem como a decadência da economia da mineração no Brasil Colônia.

Esta situação de estagnação econômica e atrofiamento da produção agrícola e extração minerária, levou a migração do excedente populacional para a atividade pecuária, que era voltada para a economia de subsistência, havendo um verdadeiro retrocesso em termos de divisão e especialização do trabalho, além da involução técnica de produção.

Diante desta situação, a Coroa Portuguesa vê-se obrigada a associar-se com outras potências para que pudesse sobreviver enquanto potência colonial. Assim, a Coroa obteve a cooperação comercial e financeira holandesa, celebrou acordos com a Inglaterra, culminando com a abertura dos portos em 1808, cooperações estas que marcariam profundamente a política e a economia não só de Portugal, mas também da colônia brasileira, de maneira que o comércio destinado ao Brasil Colônia era feito com crédito estrangeiro, especialmente inglês.

No Brasil Colonial, no que se refere às companhias existentes, o quadro era o da exploração da então Colônia por sociedades anônimas estrangeiras, que eram utilizadas como instrumento de exploração do governo português e que monopolizavam o comércio existente, inclusive o comércio de escravos. 
Com a chegada da Corte Portuguesa ao Brasil, temos a criação das primeiras sociedades anônimas brasileiras. Em 1808, foram fundados a Companhia de Seguros Boa Fé e o Banco do Brasil através dos Alvarás, respectivamente, de 24 de fevereiro e de 12 de outubro daquele ano. Nesta época, a possibilidade de constituir uma sociedade anônima era considerada um privilégio concedido pelo Estado e, portanto, dependente de prévia autorização do governo.

Inicia-se um período de transição. Embora a economia estivesse na mesma situação antes da vinda da família real ao Brasil, com a crônica ausência de meios circulatórios da riqueza, sendo o ouro em pó utilizado como moeda, e com a inexistência de instituições financeiras, há o início da formação de instituições financeiras no Brasil Colônia e, assim, o início da formação estrutural financeira do Brasil que se consolidará por volta de 1964 e 1965. Além disso, há a centralização de poder que articulou as capitanias que estavam desarticuladas e dispersas ao longo do território brasileiro, sem prejuízo do surgimento do antagonismo entre a colônia e a metrópole. Nesta primeira metade do Século XIX, houve uma preocupação voltada para a consolidação da integridade territorial brasileira e da independência política.

Com a Proclamação da Independência em 1822, iniciou-se uma tentativa de reorganização política, sem deixar de lado o equilíbrio entre a liberdade e o Poder Executivo, culminando com a promulgação da Constituição Imperial de 1824. Os primeiros vinte anos da Independência foram marcados por dificuldades financeiras, por reajustamentos políticos e por lenta mudança na economia, que estava estagnada com o declínio da fazenda. No âmbito financeiro, a circulação monetária estava limitada às notas do Banco do Brasil e ao cobre, em razão do esgotamento do metal nobre, além da existência da dívida externa contraída em 1824 em virtude do empréstimo feito e da indenização paga pela independência.

Esta primeira crise inflacionária (causada em razão da insuficiência de crédito para financiamento das novas lavouras) foi agravada com o aumento da taxa de câmbio, com a queda do comércio exterior em razão das crises havidas em 1825 e 1836 e a consequente queda dos preços do açúcar e do algodão, levando os setores tradicionais da agricultura a voltarem-se para a cultura de subsistência e/ou ao fechamento das fazendas 
entre os anos de 1831 e 1837 e, por outro lado, levou a cafeicultura à ascensão em razão dos baixos custos da empresa cafeicultora.

Todavia, a falta de crédito para a expansão cafeeira levou à intensificação da atividade dos comissários ou correspondentes, que agiam como financiadores dos cafeicultores. Os comissários, enquanto verdadeiros intermediários, representavam os fazendeiros na exportação da safra, enquanto únicos representantes dos produtores junto aos exportadores não submetidos pelo comércio estrangeiro, especialmente o britânico. Além disso, os mesmos adiantavam recursos aos fazendeiros por conta da safra futura, que era vendida ao preço corrente, mas cobravam juros por conta dos adiantamentos que faziam.

No início da segunda metade do Século XIX, o Brasil encontrava-se em situação similar ao que fora nos três séculos anteriores, com uma estrutura econômica fundada no trabalho escravo e com atraso na industrialização, uma vez que a metrópole jamais se preocupou em transferir à colônia alguma técnica que permitisse o desenvolvimento manufatureiro, sem se considerar que a renda obtida com as exportações era remetida para a metrópole ou, então, destinavam-se ao pagamento das importações, não havendo acumulação de capital para reinvestimento na atividade econômica.

A expansão da cafeicultura proporcionou o início da transição das bases do sistema econômica e, justamente, de sua crise surgiram os elementos constitutivos do sistema econômico autônomo que impulsionava o crescimento próprio. Assim, ao contrário da economia açucareira, que apresentava um isolamento das fases de produção e da fase de comercialização, esta monopolizada por Portugal que concentrava as decisões, a nova classe dirigente da economia cafeeira desenvolveu-a com a integração dos interesses da produção com os interesses da comercialização, o que, inclusive, influenciou a política financeira e econômica da época.

Esta expansão da cafeicultura promoveu, na economia brasileira, uma alta taxa de crescimento no decorrer da segunda metade do Século XIX, contudo, mesmo assim, o Brasil não conseguiu obter uma integração ao comércio mundial que estava em franca expansão, isto em razão do retrocesso econômico havido nos últimos anos, o que causou uma disparidade entre os países mais avançados, que apresentaram uma grande 
transformação de suas estruturas, e o sistema econômico brasileiro, que não apresentou transformação alguma.

Mas com esta fase de crescimento, podemos dizer que, em relação às sociedades por ações, houve o fim da $1^{a}$ Fase, que durou até a promulgação do Decreto $\mathrm{n}^{\circ}$ 575 de 1849, o qual deu início à $2^{\text {a }}$ Fase marcada pela necessidade de concessão de licença administrativa para a constituição de uma sociedade anônima, tal como ocorria com o Código Comercial Francês de 1807.

Em 1850, tivemos a promulgação do Código Comercial Brasileiro, em meio ao otimismo da prosperidade empresarial, o qual trouxe uma parca regulação acerca das sociedades anônimas em apenas cinco artigos (art. 295 ao art. 299), mantendo a necessidade de prévia concessão de licença administrativa para a constituição de uma sociedade anônima.

Aquela expansão da cafeicultura mencionada acima aliada à circulação do dinheiro gerado pelo tráfico de escravos ocasionaram um aumento real da renda, gerando, consequentemente, uma expansão das indústrias de melhoramentos urbanos e transportes, bem como relacionadas aos negócios bancários, que cresceram graças à proteção do próprio Estado, que era concedida por meio de crédito público e das verbas orçamentárias, o que, por sua vez, era obtido pela influência exercida pelos recém surgidos advogados administrativos. Assim, o Estado passou a ser, sobretudo, um verdadeiro banco de crédito, mais atuante em atividades de vigilância e intervenção, reassumindo o controle do crédito e da emissão do papel moeda, constituindo verdadeiro monopólio das emissões.

Este ambiente de prosperidade com recursos em circulação aumentou a tendência à especulação e à agiotagem, o que, segundo Raymundo Faoro, ocorreu simultaneamente à ideia governamental de crescimento e prosperidade do país em ritmo acelerado para alcançar as grandes potências, in verbis:

“Inflada a capital de recursos, desperto o país de um sono que parecia letárgico, senhor o governo do crédito, urgia queimar etapas e erguer o Brasil ao plano das grandes potências, modernizado e progressista. $O$ ambiente de prosperidade, alimentado pela especulação, sugeria mal 
dissimulada a cartola do mágico, o salto do país atrasado para o delírio do século XIX, o progresso rápido e sem fim. O voo não seria obra do trabalho, da poupança, do capital acumulado, mas do jogo, da inteligência contra a rotina, da imaginação em lugar do lento e suado passo a passo."77

Justamente este ambiente de prosperidade com o aquecimento da criação de empresas $^{78}$ sob a forma de sociedades anônimas, especialmente os inúmeros empreendimentos levados a cabo por Irineu Evangelista de Souza, mais conhecido por Barão e Visconde de Mauá, culminou, em 1857, com o que Ney Carvalho denominou a primeira bolha especulativa do Brasil, isto porque o ambiente criado gerou a expectativa e a ideia de necessidade de um mercado de capitais ágil, ativo, o que foi desenvolvido em um ambiente altamente especulativo. Desde 1850, os empreendimentos recorriam rotineiramente ao lançamento de ações no mercado de capitais para a captação de financiamentos via negociação de ações aos investidores, negociações estas que estavam desenvolvendo-se em um ambiente de liberdade, visto que vigia o então art. 45 do Código Comercial de $1850^{79}$, que permitia a realização das negociações de ações sem a intervenção de corretores.

Em 1857, com a eclosão de uma crise nos Estados Unidos da América, que ficou conhecida por "pânico de 1857" e com a consequente depressão do mercado externo, no Brasil, os negócios sofreram severa recessão, além da corrida bancária, que, surpreendentemente, não causou uma série de falências generalizadas, como bem relatou Ney Carvalho:

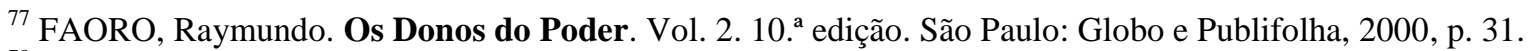
78 "A primeira metade dos anos 1850 foi época de inovações econômicas no Rio de Janeiro. A intensa atividade desenvolvida por Mauá, criando empresas e levando-as ao público, gerou clima de grande otimismo. Mesmo que inicialmente, em alguns casos, a aceitação das novas companhias não tenha sido tão favorável, criou-se a expectativa que o Brasil saía, enfim, de sua modorra agrária.

As atmosferas positivas, de esperanças róseas sobre o futuro, são caldo de cultura ideal para a formação de bolhas especulativas. As pesas passam a acreditar que o porvir será melhor que o passado e que vale a pena investir nos veículos, no caso, ações de empresas, que representam o novo destino de progresso." (CARVAlHO, Ney. A Saga do Mercado de Capitais no Brasil. São Paulo: Saint Paul, 2014, p. 83)

79 "Art. 45 - O corretor pode intervir em todas as convenções, transações e operações mercantis; sendo todavia entendido que é permitido a todos os comerciantes, e mesmo aos que o não forem, tratar imediatamente por si, seus agentes e caixeiros as suas negociações, e as de seus comitentes, e até inculcar e promover para outrem vendedores e compradores, contanto que a intervenção seja gratuita." (BRASIL. Lei n. ${ }^{\circ}$ 556, de 25 de junho de 1850. Código Comercial. Disponível em <http://www.planalto.gov.br/ccivil_03/leis/10556-1850.htm>. Acesso em 02.11.2014)
} 
"Bernardo de Souza Franco, liberal partidário de comércio e da pluralidade de emissões pelos vários bancos, assumiu o Ministério da Fazenda em 4 de maio de 1857, quando a bolha, que já perdurava alguns anos, estava em seus estertores. De fato, o movimento findou quando, em 13 de novembro, pelo navio Conrad, vindo de Nova York, chegaram notícias sobre a eclosão, em fins de agosto, do chamado 'pânico de 1857', cataclisma no qual desapareceram cerca de 1.000 bancos e casas comerciais nos Estados Unidos. No Rio de Janeiro, além da súbita retração dos negócios houve corridas bancárias, mas o sistema reagiu sem quebradeira generalizada., ${ }^{\circ 0}$

Como reação ao liberalismo praticado pelo então Ministro da Fazenda, Bernardo de Souza Franco, os conservadores combateram severamente as medidas de Bernardo de Souza Franco, culminando, quando o cargo foi assumido por Ângelo Muniz da Silva Ferraz, com a promulgação da famigerada Lei dos Entraves, a Lei n. ${ }^{\circ} 1.083 / 1860$, que aliada ao precedente Decreto n..$^{\circ}$ 2.457/1859, constituíram verdadeiro entrave à iniciativa privada, ao desenvolvimento econômico e ao desenvolvimento do mercado de capitais $^{81}$.

Nesta época, como ressaltado por Raymundo Faoro, o conjunto de medidas legislativas trazem à tona o Estado mercantilista, que tomou diversas iniciativas legislativas de prevenções contra a criação de sociedades por ações, bem como contra a livre circulação de suas ações, de modo que o Estado praticamente tornou-se o dirigente do direito de associação, uma vez que a ele foi atribuída a incumbência de decidir se o objeto das sociedades anônimas a serem criadas era, ou não, lícito, bem como se era, ou não, de utilidade pública, cabendo ao governo "licenciar e aprovar os estatutos das sociedades,

\footnotetext{
${ }^{80}$ CARVAlHO, Ney. A Saga do Mercado de Capitais no Brasil. São Paulo: Saint Paul, 2014, p. 86.

81 "Apesar do eufemismo pretendido, Lei de Prudência, aquele diploma passou à história como Lei dos Entraves, o que era na realidade (...) A vigência da Lei dos Entraves, por duas décadas, foi grande empecilho ao desenvolvimento do mercado de capitais e, portanto, da economia do Brasil ao longo do século 19. O aspecto nevrálgico da lei é que ela fulminava a liberdade de empreender, alma do progresso de qualquer nação." (CARVALHO, Ney. A Saga do Mercado de Capitais no Brasil. São Paulo: Saint Paul, 2014, p. 89)
} 
subordinando a empresa a um governo disposto a não auxiliar a indústria. ${ }^{~} 82$ Raymundo Faoro prossegue:

“Durante vinte anos, a tutela governamental freará o desenvolvimento econômico, matando, com a especulação de 1857, os agrupamentos destinados à indústria e ao comércio, a este vinculado. Um outro golpe completará o elenco de medidas voltadas para estancar a heterodoxia financeira, este tendente a reduzir a tarifa aduaneira, com a liquidação do sistema Alves Branco." 83

Nesta segunda metade do Século XIX, encontra-se uma situação em que o empresário reclama por maior liberdade econômica, mas ao mesmo tempo requer o estímulo estatal, seja com a concessão de crédito público subsidiado, seja pela concessão de proteção alfandegária, de forma a envolver o Estado no âmbito negocial privado, surgindo, o que Raymundo Faoro denominou de "neomercantilismo dos liberais".

Neste ambiente de controle das atividades econômicas privadas pelo Estado, inicia-se, no final do Século XIX, um movimento favorável ao liberalismo político e ao liberalismo econômico, com a valorização da livre concorrência, da lei da oferta e da procura, das trocas internacionais livres de impedimentos e de protecionismos, além do surgimento de ideias que objetivam discutir a reformulação do sistema financeiro, que até 1888 estava fundado na centralização das emissões e da regulação do papel-moeda no Tesouro.

Somente em 1882, podemos afirmar que, em relação ao regime jurídico das sociedades anônimas, tivemos o início da $3^{\text {a }}$ Fase no Brasil, quando da promulgação da Lei $n^{\circ} 3.150 / 1882$, a qual deu início à fase de liberdade de constituição das companhias, justamente ao revogar as restrições criadas pela Lei n. ${ }^{\circ} 1.083 / 1860$ no que concerne à criação das sociedades por ações e à circulação de seus valores mobiliários, inclusive, prevendo o que se poderia designar como a origem das atuais partes beneficiárias, ao dispor no $\S 3 .^{\circ}$, do art. $3 .^{\circ}$ que "é lícito, depois de constituída a sociedade, estabelecer-se em favor dos fundadores ou de terceiros, que hajam concorrido com serviços para a

${ }_{83}^{82}$ FAORO, Raymundo. Os Donos do Poder. Vol. 2. 10. ${ }^{a}$ edição. São Paulo: Globo e Publifolha, 2000, p. 35.

${ }^{83}$ Idem, ibidem, p. 35. 
formação da companhia, qualquer vantagem consistente em uma parte dos lucros líquidos ${ }^{\$ 4}$, bem como estabelecendo a ampla liberdade na regulação do exercício do direito de voto em assembleias. Assim, estava iniciada, no Brasil, a fase moderna, podendo-se perceber que o Brasil caminhou rapidamente da $1^{\text {a }}$ Fase para a $3^{\text {a }}$ Fase da espécie societária em comento.

Nesse ínterim, foi proclamada a abolição da escravatura em 1888, o que atingiu diretamente a agricultura e, consequentemente, a classe dos comissários, que eram os verdadeiros credores urbanos dos agricultores e, justamente por isso, iniciaram execução das fazendas hipotecadas para a satisfação de seus créditos inadimplidos com este choque causado pela libertação dos escravos, de forma a se constatar o deslocamento da riqueza que se concentrava nas fazendas para o comissariado.

Entre os anos de 1888 e 1890, as medidas governamentais no âmbito financeiro não fomentavam a produção das fazendas, que estavam em grave declínio, mas, sim, fomentavam o setor dos intermediários do crédito e do comércio, que começava a adquirir grande expressão, resultando na criação de empresas, bancos e companhias em maior número. Com tais medidas, houve um aumento do papel-moeda em circulação, de forma que o mercado interno apresentou uma expansão no consumo diante de um setor exportador incapaz de promover as exportações, além do aumento da atividade industrial no Rio de Janeiro com nítido caráter especulativo e da dependência dos produtores agrícolas do estímulo governamental.

Em São Paulo, ao contrário das diretrizes surgidas no âmbito agrícola e industrial do Rio de Janeiro, firmava-se um pensamento contrário à aliança do produtor com o importador, mas fundado no protecionismo, no nacionalismo, contrário à dominação do comércio pelos estrangeiros, de maneira que se pregava a associação da independência do país à industrialização e ao abastecimento do mercado interno, além do apoio da estrutura financeira à industrialização, mas contrário ao esquema implantado pela monocultura em associação ao capital estrangeiro.

\footnotetext{
${ }^{84}$ BRASIL. Lei n. ${ }^{\circ} 1.083$, de 22 de agosto de 1860. Contendo providências sobre os bancos de emissão, de meio circulante e diversas companhias e sociedades. Disponível em < http://www.planalto.gov.br/ccivil_03/leis/LIM/LIM1083.htm>. Aceso em 02.11.2014.
} 
À ruptura econômica causada pela abolição da escravatura e ao otimismo gerado pelas perspectivas econômicas advindas da libertação dos escravos, aliou-se um movimento de criação de sociedades por ações com o uso intensivo do crédito, que era concedido pelas novas companhias criadas aos especuladores-investidores que adquiriam as ações lançadas no mercado de capitais. Em paralelo a esta situação de otimismo, em 15.11.1889, a República é proclamada e é acompanhada de medidas de cunho liberal e desenvolvimentista, constituindo outra ruptura econômica.

No âmbito econômico, constatou-se uma desvalorização do câmbio, uma redução do meio circulante, levando o governo a fazer emissões de papel-moeda e a cobrar impostos alfandegários em ouro para evitar o recebimento de papéis inconversíveis e, ainda, a limitar a criação de novas companhias com as medidas consubstanciadas no Decreto n. ${ }^{\circ} 850$, de 13.10.1890, impondo a obrigação de depositar o equivalente a $30 \%$ (trinta por cento) do capital social em dinheiro, bem como a permissão de negociação das ações somente após a integralização de $20 \%$ (vinte por cento) do valor das ações subscritas.

Tais medidas contra as ações especuladoras surtiram efeito no mercado, restringindo o ingresso de capitais estrangeiros, mas esta retração foi temporária, pois o mercado de capitais retomou o seu ritmo já em dezembro de 1890, de forma que, segundo os dados informados por Ney Carvalho ${ }^{85}$, desde a abolição da escravatura até março de 1891 houve um aumento de $365 \%$ (trezentos e sessenta e cinco por cento) na quantidade de companhias que negociavam suas ações em bolsa de valores. Contudo, em 14.02.1891, foi promulgado o Decreto n..$^{\circ} 1.362$, que instituiu a cobrança de imposto de 3\% (três por cento) sobre as operações futuras, que naquela época constituíam a fonte principal de financiamento da compra de ações, o que causou uma queda vertiginosa no preço das ações, além da greve iniciada pelos corretores da Bolsa de Valores do Rio de Janeiro.

Estava, assim, concretizada a crise que ficou conhecida por Encilhamento, cujas consequências maléficas são assim justificadas por Ney Carvalho:

"O decreto de Alencar Araripe provocou um súbito e definitivo estancamento no mercado, com queda generalizada nos preços das

${ }^{85}$ CARVAlHO, Ney. A Saga do Mercado de Capitais no Brasil. São Paulo: Saint Paul, 2014, p. 120. 
frações de ações negociadas na bolsa e no Encilhamento. Cabe relembar o que foi salientado no capítulo anterior sobre usos e costumes. Uma vez subscrita uma ação e integralizados $10 \%$ de seu valor, essa parcela poderia ser vendida no mercado, em que pese a iniciativa de Ruy Barbosa de elevar tal mínimo para 30\%, mas somente em outubro de 1890. Contudo, o nível de capitalização das empresas já lançadas era extremamente precário, o que indicava fragilidade em face de qualquer baixa mais grave.

O quadro de companhias publicado pelo Jornal do commercio, em 16 de março de 1891, um mês após a tempestade provada por Araripe, trazia um panorama de como era débil o volume das 456 empresas listadas. Apenas 74, ou 16,2\%, tinham o capital totalmente integralizado, ou seja, independiam dos acionistas, para prosseguir com suas atividades. As demais, em um momento ou outro, demandariam novas parcelas de seus subscritores.

Trinta dias mais tarde, a edição do JC, de 17 de abril, publicava 40 editais de empresas variadas convocando os acionistas para integralizarem novas chamadas de capital. Ocorre que com a debacle provocada pelo ministro da Fazenda, as frações de $10 \%$ estavam cotadas a menos do que seu valor par, usualmente de 20 mil réis, cifra a ser paga obrigatoriamente. Ora, com os papéis valendo 18, 16, 14 mil réis, ou menos, a continuidade da subscrição a 20 mil réis era prejuízo necessário, desestimulando o comparecimento $e$ incentivando a inadimplência dos possuidores de ações.

$\mathrm{Na}$ verdade ao aceitarem a subscrição parcelada, as empresas concediam crédito a seus acionistas. Assim, assumiam compromissos contando com os aportes nos momentos em que fossem chamados pela diretoria. E a única ferramenta que tinham contra os relapsos era a ameaça do comisso. Foi esse duplo enlace que levou à tragédia 
econômica do Encilhamento. As empresas faliam ao descumprirem suas obrigações, devido ao não ingresso do capital com que contavam dada a inadimplência dos subscritores. Já estes perdiam as economias investidas, anteriormente, pela aplicação da pena de comisso." 86

Diante desta situação, o Governo editou novo regulamento das sociedades anônimas, por meio do Decreto n. ${ }^{\circ}$ 603, de 20.10.1891, pelo qual instituiu medidas dificultadoras da aplicação da pena de comisso aos acionistas inadimplentes. Além da situação grave da crise do Encilhamento, vivia-se uma época de instabilidade política, com o início do Governo de Floriano Peixoto, que, inclusive, fechou o Congresso Nacional em 03.11.1891, motivo pelo qual as medidas tomadas pelo governo para tentar solucionar a crise tiveram efeitos limitados.

Não obstante a situação de grave crise, as indústrias fundadas no primeiro momento de crescimento industrial não pereceram, especialmente porque foram favorecidas pela queda da taxa cambial e pela elevação dos impostos alfandegários. Em paralelo ao setor industrial, a agricultura cafeicultora experimentou um aumento de sua produção, que era escoada por meio das exportações proporcionadas pela aproximação dos exportadores estrangeiros aos agricultores, sem a intermediação dos comissários, até que, em 1893, a cafeicultura sofreu os efeitos da superprodução, sendo que somente os agricultores não dependentes dos adiantamentos dos banqueiros ou dos exportadores conseguiram prosseguir após a crise, os quais, após a celebração e o êxito financeiro do Convênio de Taubaté em 1906, demonstraram sua força e submeteram o governo central à política econômica por eles desejada.

A partir de 1905, o movimento industrial voltou a ter um ritmo de crescimento, em especial a indústria paulista que passou a exercer uma primazia principalmente em razão da imigração, da urbanização e do crescente consumidor assalariado, além de se tratar de uma indústria independente dos favores e do protecionismo estatal, primando pelo ideal do liberalismo econômico, contrapondo-se à indústria do então Distrito Federal (Guanabara), que era dependente do protecionismo e dos favores governamentais e, por isso, subjugada às coordenadas políticas.

${ }^{86}$ CARVAlHO, Ney. A Saga do Mercado de Capitais no Brasil. São Paulo: Saint Paul, 2014, p. 123. 
A partir de 1906, há um rigoroso combate aos mecanismos de comando político da economia, cessando o protecionismo, as manipulações financeiras, as garantias de juros e as concessões e intervenções estatais, havendo uma revitalização da indústria com o foco voltado para a reconquista do mercado interno, com a concessão de proteção à indústria nacional até o momento em que ela se achasse em condições de concorrer com a indústria estrangeira, além da reorganização da agricultura.

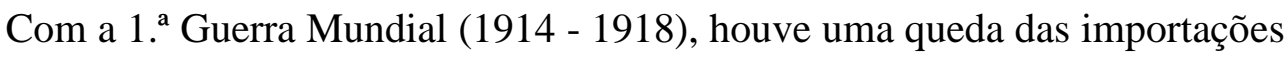
e um aumento do consumo pelo mercado interno, em virtude da existência de um maior número de trabalhadores nas indústrias, sendo que o governo assumiu o papel de intermediador da produção nacional perante o mercado internacional. Especialmente no pós-guerra, o governo tentou obter a reestruturação financeira com a estabilidade cambial, com a dotação da moeda nacional com seu real valor e, ainda, atingir a conversibilidade da moeda, para então culminar com a circulação metálica, além dos incentivos às exportações que atrairiam um afluxo de capitais e, assim, poderiam proporcionar condições ao desenvolvimento do país.

Nesse momento, durante o governo de Washington Luís, a "supervisão governamental despia-se do comando econômico, guardando-se de intervenções que não fossem apenas formalmente de controle e coordenação" ${ }^{\# 7}$, voltando-se nitidamente para a adoção do modelo industrial paulista, que estava associado à agricultura e ao setor importador, sem dependência das benesses governamentais, assumindo a agricultura e a indústria, em um futuro próximo, o caráter de empresa.

Após a crise iniciada nos Estados Unidos da América em 1929, que se espalhou para o âmbito mundial, a agricultura brasileira sofreu severamente as consequências da crise, visto que se encontrava endividada perante os banqueiros (antigos comissários que se transformaram em banqueiros) e/ou os exportadores, o que fez ruir o modelo paulista adotado no âmbito nacional, visto que o mesmo estava fundado na capacidade de exportar café, sendo que o ouro, que ingressava pela exportação de café, financiaria os novos empreendimentos. Esta queda do consumo levou a cafeicultura à crise, o que, por sua vez, causou a intervenção estatal no domínio econômico.

${ }^{87}$ FAORO, Raymundo. Os Donos do Poder. Vol. 2. 10. ${ }^{a}$ edição. São Paulo: Globo e Publifolha, 2000, p. 339. 
Com a ascensão de Getúlio Vargas ao poder em 1930, há uma clara mudança em termos de atuação do Estado na economia. Inicia-se um período de contraposição ao liberalismo econômico, voltado à atuação ditatorial do Estado, criando condições frontalmente contrárias ao mercado de capitais e aos negócios, como bem retratou Ney Carvallho:

"O mercado de capitais não foi beneficiado por progressos ou modernizações durante os 15 anos do governo ditatorial de Getúlio Vargas, entre 1930 e 1945, ao contrário, regrediu, definhou. Nem mesmo a revolução que levou Vargas ao poder trouxe expectativas favoráveis que impulsionassem as bolsas. Bastante diferente de outras mudanças substanciais de regime político em que incorreu o país. Na República, em 1889, as esperanças no futuro econômico serviram de segunda combustão ao Encilhamento que grassava desde a Abolição, em 1888. Já em 1964, raiz dos governos militares, um processo de reordenação do mercado eclodiu na bolha de 1971.

É fato no início dos anos 1930 o mundo vivia os rescaldos da crise de 1929, clima nada propício ao crescimento de mercados. Entretanto, o primeiro governo Vargas se estendeu até 1945 e praticamente todas as providências que dele emanaram, agiram no sentido antinegócios e antimercado. Mais ainda, 80\% daqueles 15 anos (1930 a 1934, e 1937 a 1945) foram vividos em sistema ditatorial no qual as leis derivavam de decretos autocráticos, de exclusiva competência do presidente da República." $" 88$

Assim, a legislação produzida na época do governo Vargas levou todas as atividades privadas à burocratização, no que se incluiu a legislação das sociedades por ações, do capital estrangeiro etc. Ademais, a legislação das sociedades anônimas, então vigente, foi alterada inúmeras vezes por decretos expedidos pelo Governo, de modo que se mostrou necessária a consolidação da matéria relativa às sociedades anônimas, dando,

${ }^{88}$ CARVAlHO, Ney. A Saga do Mercado de Capitais no Brasil. São Paulo: Saint Paul, 2014, p. 155. 
assim, início a um movimento de reforma e consolidação da legislação pertinente àquele tipo de sociedade a partir da promulgação da Constituição de 1891.

Contudo, segundo Francisco Campos, então Ministro da Justiça do governo Vargas, a finalidade da reforma da legislação das companhias era a de transformar o caráter das companhias abertas brasileiras, que até então possuíam feições de uma democracia societária, para "transformá-las em empresas submetidas a controladores definidos, o que seria obtido com a eliminação do direito de voto aos acionistas particulares, oriundos do mercado." 89

Não obstante a intenção de reformulação geral da lei das companhias, o governo continuava a alterar a referida legislação, tal como, por exemplo, (i) a introdução das ações preferenciais no direito brasileiro por meio do Decreto n. ${ }^{\circ} 21.536$, de 15.02.1932, cujo objetivo era afastar as minorias acionárias da ingerência com a eliminação do direito de voto, bem como (ii) a restrição da liberdade de ação da comunhão dos debenturistas contra a companhia, o que foi operacionalizado pelo Decreto n. ${ }^{\circ} 22.431$, de 06.02.1933.

Com a eclosão da 2. ${ }^{\text {a }}$ Guerra Mundial em 1939, a nacionalização das empresas ficou prejudicada, mas obteve-se o predomínio brasileiro nas mesmas com a colaboração norte-americana, isto é, o Estado claramente adotou uma economia politicamente orientada, com as indústrias de base controladas pelo Estado, com participação de acionistas nacionais e estrangeiros. Desse modo, a intervenção estatal no domínio econômico ocorreu sob a justificativa de (i) suprir as deficiências da iniciativa privada, (ii) coordenar os fatores de produção para evitar ou solucionar conflitos ou, ainda, (iii) incutir os interesses da nação nas concorrências individuais.

Após inúmeras tentativas frustradas de reforma da legislação das sociedades anônimas, Trajano de Mirada Valverde foi incumbido de elaborar um Anteprojeto de lei das companhias, o qual, após algumas revisões, culminou com o Decreto-lei n. ${ }^{\circ}$ 2.627/1940. Contudo, o Decreto-lei no 2.627/40 era voltado para pequenas e médias empresas com número reduzido de acionistas, os quais estavam voltados e interessados na exploração do objeto social, possuindo, inclusive uma participação no poder decisório da companhia, não se destinando, por isso, às empresas que se envolviam em grandes

${ }^{89}$ CARVAlHO, Ney. A Saga do Mercado de Capitais no Brasil. São Paulo: Saint Paul, 2014, p. 156. 
empreendimentos, sem se considerar, também, que o retro referido Decreto-lei visava à companhia de capital fechado. A partir de 1940, o Estado passou a caracterizar-se como grande investidor na economia produtiva brasileira, seja lançando ações da Companhia Siderúrgica Nacional em 1941, seja pelo lançamento de ações da Companhia Vale do Rio Doce em 1942.

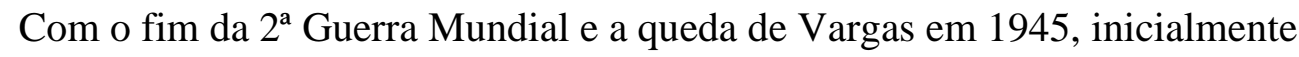
a situação permaneceu a mesma em termos de mercado de capitais, com a manutenção do mesmo regime desde 1890 com as modificações posteriores, mas sem grandes rupturas. Todavia, iniciou-se a instalação de grupos norte-americanos no Brasil, de forma que a iniciativa privada reinventava e/ou inovava métodos de lançar valores mobiliários como fonte de captação da poupança pública. Em contrapartida, especialmente após a volta de Getúlio Vargas ao poder, o Estado continuou a utilizar mecanismos obrigatórios para a captação de recursos para a execução de seus projetos, o que, segundo Ney Carvalho, contribuiu "de modo intenso para o descrédito do mercado de capitais e seus instrumentos, como títulos públicos, debêntures e até ações (...) Os danos à imagem do mercado e seus títulos não são mensuráveis, mas, sem dúvida, tais fatos colaboraram intensamente para o clima de desprestígio e abandono vivido pelas bolsas até a legislação renovadora de meados da década de 1960."90

Neste período, constatou-se o início da mudança da estrutura da economia, que deixou de conferir excessiva importância à procura pelo mercado externo como fator de determinante do nível de renda, para iniciar um desenvolvimento baseado na criação de capacidade produtiva para a satisfação do consumo do mercado interno, que deixou de ser satisfeito por meio das importações, mas que, segundo Raymundo Faoro, esse desenvolvimento apresentou-se "basicamente como um processo de articulação das distintas regiões do país em um sistema com um mínimo de integração."91 No que concerne ao mercado de capitais, houve uma expansão dos negócios realizados nas bolsas, o que foi impulsionado pelo processo inflacionário que levava à busca por ações que constituíam, na verdade, ativos reais protegidos pela desvalorização da moeda.

\footnotetext{
${ }^{90}$ CARVAlHO, Ney. A Saga do Mercado de Capitais no Brasil. São Paulo: Saint Paul, 2014, p. 175.

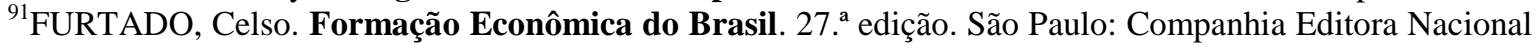
e Publifolha, 2000, p. 248.
} 
Em 1964, como resultado da instabilidade política e econômica vivida no governo de João Goulart, ocorreu o golpe militar com a assunção da presidência por Castello Branco, que demonstrava uma inclinação liberal no núcleo financeiro do governo, que visava de imediato à restauração do crédito público, instituindo mecanismo de correção monetária. Outra medida foi a reforma do sistema financeiro nacional com a promulgação da Lei n. ${ }^{\circ}$ 4.595, de 31.12.1964.

Após iniciou-se a discussão sobre modificações estruturais das bolsas de valores, momento em que os grandes empreendimentos necessitavam do financiamento por meio menos custoso para obter a sua expansão empresaria, de modo que seria necessário estimular o desenvolvimento do mercado de valores mobiliários, tornando-o como principal aliado do empresário, ficando reforçada, igualmente, a constatação anterior de inadequação da legislação das sociedades anônimas em vigor. Justamente para o fim de regular o mercado de valores mobiliários e criar condições estruturais para fomentar o seu desenvolvimento, foi promulgada a Lei n ${ }^{\circ}$ 4.728, de 14.07.1965.

Dentre as medidas instituídas pela Lei n. ${ }^{\circ}$ 4.728/65, em suma, esta (a) criou uma estrutura indutora da criação de sistema de distribuição de títulos no mercado de capitais, (b) estabeleceu condições para a formação de mercado de obrigações privadas a médio e longo prazos, (c) estabeleceu normas reguladoras da atividade fiscalizadora nos moldes da Securities and Exchange Comission (SEC), (d) trouxe inovações pontuais no Decreto-lei n. ${ }^{\circ}$ 2.627/40 e na regulação de debêntures, bem como (e) alterou a legislação tributária pontualmente.

Paralelamente à legislação, o Governo deu início à concessão de incentivos fiscais não só para o empresário abrir o capital de sua companhia, mas também para incentivar a aplicação da poupança privada diretamente na atividade produtiva via mercado de valores mobiliários. Todas as medidas adotadas pelo Governo resultaram em um estímulo ao mercado de valores mobiliários, que apresentou um crescimento gradativo. Juntamente com o desenvolvimento econômico acelerado, as Bolsas de Valores apresentaram um movimento de rápido crescimento e de aumento do preço de valores mobiliários sem precedentes. Contudo, tratava-se de um movimento especulativo de 
grandes proporções, tão grave quanto a crise do encilhamento ocorrida entre os anos de 1889 e 1891.

A crise ocorrida em 1971 serviu para reforçar a inadequação da legislação das sociedades anônimas e do mercado de capitais em vigor à realidade econômica brasileira, demonstrando a real necessidade de sua integral reforma para criar um modelo compatível com grandes empresas voltadas a grandes empreendimentos, bem como voltado à utilização do mercado de valores mobiliários como fonte primordial do financiamento empresarial em contraposição ao financiamento bancário, este mais custoso. É com base na situação que foram promulgadas sequencialmente a Lei n. ${ }^{\circ} 6.385$, de 07.12.1976 e a Lei n. ${ }^{\circ}$ 6.404, de 15.12.1976.

A Lei n. ${ }^{\circ}$ 6.385/76 criou a Comissão de Valores Mobiliários enquanto ente fiscalizador do mercado de valores mobiliários e trouxe normas específicas acerca do mercado de valores mobiliários. Embora não estivesse expressamente reconhecida na lei retro mencionada, a Comissão de Valores Mobiliários exercia atividade típica de agência reguladora nos termos do previsto no art. 174 da Constituição Federal de 1988, o que somente foi claramente previsto com a reforma introduzida pela 10.303, de 31.10.2001.

Oito dias após a promulgação da Lei n. ${ }^{\circ}$ 6.385/76, foi promulgada a Lei n. ${ }^{\circ}$ 6.404/76 que revogou o Decreto-lei n. ${ }^{\circ} 2.627 / 40$ e trouxe a nova regulamentação das sociedades por ações que se encontra em vigor até os dias atuais. Com esta estrutura legislativa, o Brasil visou abarcar a grande empresa voltada a grandes empreendimentos, que constituem a base da economia de mercado.

Com efeito, a Lei n. ${ }^{\circ}$ 6.404/76 foi estruturada com base em um paradigma centrado na figura do empresário-empreendedor, que detém o poder de controle concentrado em suas mãos e, por isso, comanda os rumos da empresa. Além disso, a referida lei visou ao desenvolvimento do mercado primário de ações com fundamento na 
companhia de capital aberto, sem prejuízo de ter visado, igualmente, o desenvolvimento do mercado de outros títulos e valores mobiliário ${ }^{92}$.

Assim, no Brasil, deu-se início à formação da estrutura jurídica necessária à macroempresa, enquanto instituto jurídico que reúne um grande número de interesses e apresenta uma função social (conforme dispõe o art. 116, parágrafo único, da Lei $\mathrm{n}^{\circ}$ $6.404 / 76^{93}$ ), além de servir de base à economia de mercado.

A partir da promulgação da Lei n. ${ }^{\circ}$ 6.404/76, houve a descentralização do exercício das três funções econômicas do empresário, isto é, a função empreendedora continuou sendo exercida pelo acionista majoritário. Já o exercício da chefia da estrutura hierárquica da empresa passou a ser exercida por administradores, enquanto que a assunção dos riscos econômicos do empreendimento passou a ser dividida com os demais acionistas, os quais, por sua vez, têm responsabilidade limitada ao valor de subscrição ou ao preço de emissão das ações (art. $1^{\text {o }}$ da Lei n. ${ }^{\circ} 6.404 / 76^{94}$ ).

Percebe-se, desse modo, que a criação da estrutura jurídica necessária ao suporte da macroempresa objetivou, segundo os autores do anteprojeto da Lei n. ${ }^{\circ}$ 6.404/76, Alfredo Lamy Filho e José Luiz Bulhões Pedreira ${ }^{95}$, conferir às companhias de grande porte uma maior estabilidade econômico-financeira para atuarem em mercados altamente competitivos, bem como permitir-lhes o usufruto dos benefícios decorrentes da grande dimensão empresarial, quais sejam:

a) a redução dos custos de produção em decorrência da produção em larga escala;

92 A propósito, vide: MUNHOZ, Eduardo Secchi. Aquisição de Controle na Sociedade Anônima. São Paulo: Saraiva, 2013, p. 50 - 57; e OIOLI, Erik Frederico. Oferta Pública de Aquisição do Controle de Companhias Abertas. São Paulo: Quartier Latin, 2010, p. 53 - 56.

93 “Art. 116. (...)

Parágrafo único. $O$ acionista controlador deve usar o poder com o fim de fazer a companhia realizar o seu objeto e cumprir sua função social, e tem deveres e responsabilidades para com os demais acionistas da empresa, os que nela trabalham e para com a comunidade em que atua, cujos direitos e interesses deve lealmente respeitar e atender." (BRASIL. Lei n. ${ }^{\circ}$ 6.404, de 15 d dezembro de 1976. Dispõe sobre as sociedades por ações. Disponível em <http://www.planalto.gov.br/ccivil_03/leis/16404consol.htm>. Acesso em: 02.11.2014)

94 "Art. $1^{\circ}$ A companhia ou sociedade anônima terá o capital dividido em ações, e a responsabilidade dos sócios ou acionistas será limitada ao preço de emissão das ações subscritas ou adquiridas." (Idem, ibidem)

${ }^{95}$ A propósito vide os comentários dos autores do anteprojeto, Alfredo Lamy Filho e José Luiz Bulhões Pedreira, in A Lei das S.A., Rio de Janeiro: Renovar, 1992, p. 68 a p. 72. 
b) a integração do processo produtivo verticalmente, ou seja, com outros setores do mercado produtivo;

c) a obtenção de maior poder econômico não só nos mercados, mas também perante os governos locais;

d) a capacidade de planejamento a longo prazo;

e) o financiamento da expansão empresarial via mercado de valores mobiliários ou, ainda, por meio do reinvestimentos dos lucros, de modo a eliminar o custo relativo ao financiamento bancário; e

f) o aumento da capacidade de desenvolvimento e pesquisa não só em relação aos produtos existentes, como forma de aprimorá-los, mas também para a criação de novos produtos.

Contudo, o Brasil sempre apresentou, na história das sociedades anônimas, um predomínio de sociedades familiares com capital concentrado, de modo que o poder de controle variava entre o poder de controle majoritário e o totalitário, o que implicou na existência de um fraco governo das sociedades anônimas. Aliás, há estudos que relacionam a adoção do modelo societário de capital concentrado à fraca governança corporativa da sociedade, enquanto que outros estudos ligam, a concentração acionária à dependência da trajetória seguida na formação econômica do país e aos fatores de resistência que impedem ou dificultam a mudança para a dispersão acionária.

Embora a legislação brasileira tenha demonstrado certa evolução no tratamento do mercado de capitais e das companhias, no âmbito econômico, o período compreendido entre os anos de 1964 e 1967 foi um período de estabilização econômica, com sérios cortes dos déficits públicos, maior controle da inflação, dentre outras medidas econômicas. Entre os anos de 1968 e 1973, a economia apresentou um crescimento rápido com a expectativa de manutenção dos preços, sem grandes pressões inflacionárias, sendo que em 1974 "a economia já estava produzindo bem acima da capacidade e as pressões inflacionárias já se encontravam presentes, quando o primeiro choque do petróleo 
encarregou de aumentar os custos e puxar a inflação para cima"96, que era mantida em movimento ascendente pelo mecanismo de indexação.

Esta situação ascendente da inflação culminou com alta vertiginosa dos preços, que foi estimulada pelo aumento do preço do petróleo, com duas maxidesvalorizações ocorridas a primeira em 1979 e outra em 1983, ano em que se atingiu uma taxa de inflação acumulada de 200\% (duzentos por cento), o que levou à adoção de uma política monetária austera que causou o aumento das taxas de juros, recessão e desemprego ${ }^{97}$, sendo que a inflação se manteve em patamares similares ao de 1983 nos anos que se seguiram.

Com a volta da democracia, desde 1985, a inflação mantinha-se em patamares elevados, o que levou à adoção, pelos governos que se seguiram, de diversos planos econômicos sem êxito no controle da inflação, sendo que, somente em 1994, com o Plano Real o Brasil atingiu a estabilidade monetária. Por meio da adoção de diversas reformas, com a redução da participação estatal na economia, com o fim de monopólios econômicos e com as privatizações e a adoção de um "tripé de políticas - metas de inflação, câmbio flutuante e austeridade fiscal -, adotado no período FHC, conferiu as bases para a almejada estabilidade macroeconômica do país, que voltou a inserir-se na economia internacional e a receber fluxo constante de investimentos estrangeiros diretos" ${ }^{\prime 98}$.

Ainda, segundo Eduardo Secchi Munhoz, "em vista desse conjunto de fatores - estabilidade monetária, abertura comercial e financeira, privatizações e liquidez do mercado, financeiro internacional -, era de se esperar que a década de 1990 assistisse ao florescimento do mercado de capitais no Brasil. Essa expectativa, porém, não se realizou." "99 Dessa maneira, em 1997, com as privatizações das empresas estatais, que foram marcadas pelo enfraquecimento da proteção dos minoritários, iniciou-se um

\footnotetext{
${ }^{96}$ CARDOSO, Eliana A. Economia Brasileira ao Alcance de Todos. 14. ${ }^{a}$ edição. São Paulo: Brasiliense, 1993, p. 94 - 95.

97 "O arrocho dos meios de pagamentos em face da inércia inflacionária resulta em redução do crédito, acarretando um aumento das taxas de juros; em seguida os empresários quebram, a produção se contrai e o desemprego aumenta." (Idem, ibidem, p. 99)

${ }^{98}$ MUNHOZ, Eduardo Secchi. Aquisição de Controle na Sociedade Anônima. São Paulo: Saraiva, 2013, p. 61.

${ }^{99}$ Idem, ibidem, p. 61 - p. 62.
} 
movimento de melhora e aprimoramento das normas relativas aos direitos dos acionistas minoritários e à governança corporativa, marcado pela defesa da concessão de maiores direitos econômicos, políticos e fiscalizatórios aos acionistas minoritários. Esse movimento culminou com iniciativas de autorregulação das empresas, especialmente no que se refere à adoção de práticas de governança corporativa.

Logo, em contraposição ao enfraquecimento dos direitos dos minoritários na época das privatizações, as funções autorreguladora e reguladora apresentaram uma forte atuação que influenciou o legislador brasileiro, o qual, na época em que os países vizinhos sofriam graves crises, viu-se obrigado a demonstrar aos investidores a maturidade do modelo brasileiro de desenvolvimento, bem como a tentar obter um maior desenvolvimento e fortalecimento do mercado de valores mobiliários para propiciar o financiamento dos agentes econômicos privados via mercado.

Foi, justamente, com essa finalidade que foi promulgada a Lei n. $^{\circ}$ 10.303/2001, que reformou não só a Lei n. ${ }^{\circ}$ 6.385/76, mas também a Lei n. ${ }^{\circ}$ 6.404/76.

Nas palavras de Emerson Kapaz ${ }^{100}$, a Lei n. ${ }^{\circ}$ 10.303/2001 teve a primordial finalidade de instituir um ciclo virtuoso marcado pela concessão de maior proteção aos acionistas minoritários, o que proporcionaria maior liquidez ao mercado e, assim, as empresas seriam estimuladas a lançar ações no mercado de valores mobiliários, o que atrairia mais os investidores na aquisição dos títulos e valores mobiliários.

Atualmente, o Brasil, parece-nos, encontra-se em uma fase de estagnação após a tentativa de direcionar as companhias de capital aberto à dispersão acionária via adesão aos níveis diferenciados de governança corporativa da então Bovespa.

Como é sabido, o Brasil é marcado pela predominância de sociedades anônimas com capital concentrado. Contudo, com o início das iniciativas de autorregulação no campo da governança corporativa, começou-se a verificar um movimento voltado à dispersão acionária com a adesão aos níveis diferenciados de governança corporativa criados pela iniciativa autorregulatória da Bovespa.

${ }^{100}$ KAPAZ, Emerson. Lei das S.A.: Uma Contribuição Decisiva. In: LOBO, Jorge. Reforma da Lei das Sociedades Anônimas. Rio de Janeiro: Forense, 2002, p.1 - 2. 
Mas, conforme estudos já desenvolvidos, nem sempre um sistema de direito societário apresenta uma convergência formal, visto que há diversos fatores de resistência a tal convergência formal, tais como a dependência histórica estrutural a dado sistema, o alto custo decorrente da manutenção da empresa no novo sistema, custos estes que são irrecuperáveis, a resistência de adaptação ao novo sistema pelas atividades complementares desenvolvidas no entorno da empresa, as quais levam em conta o tempo e o custo investidos e, ainda, a possibilidade de haver múltiplos sistemas eficientes, sendo que cada sistema busca sua eficiência levando em conta as condições de sua região.

Assim, diante da existência de diversos fatores de resistência à convergência formal, constata-se um movimento, inclusive no Brasil, de convergência funcional, sem provocar a mudança de toda a estrutura já existente e adaptada ao sistema de capital concentrado.

Talvez isto explique o movimento limitado de adesão aos níveis de governança corporativa da Bovespa, mesmo após a atuação autorregulatória e regulatória indutora à dispersão do capital, com a adoção de práticas de governança corporativa, mesmo tendo havido uma redução dos custos de abertura do capital de 5,1\% para 3,4\% do valor da operação, conforme estudo desenvolvido pela Deloitte Touche Tohmatsu ${ }^{101}$.

Quanto ao futuro do sistema de direito societário brasileiro (de capital concentrado), é difícil prever qual rumo tomará, o da convergência formal ou, ainda, teremos a manutenção do sistema de capital concentrado com reduzido número de companhias aderentes aos níveis diferenciados de governança corporativa, restando-nos apenas aguardar.

Além das mudanças já sofridas no curso de sua evolução histórica, o instituto jurídico das sociedades anônimas, assim como qualquer outro instituto jurídico, necessita ser aprimorado consoante a evolução histórico-social. Conforme Fábio Konder Comparato, “não existe, assim, um conceito 'puro' e imutável de sociedade anônima, ou mesmo de sociedade mercantil, mas definições aproximativas, em cada época histórica.

\footnotetext{
${ }^{101}$ DELOITTE TOUCHE TOHMATSU. Custos para Abertura de Capital no Brasil - Uma Análise sobre

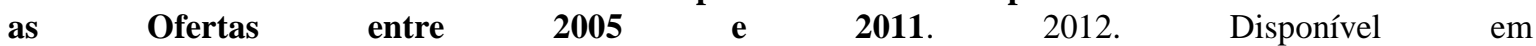
<http://www.bmfbovespa.com.br/empresas/download/Guia-Custos-para-abertura-de-capitalBMFBOVESPA-Deloitte.pdf>. Acesso em 02.09.2012.
} 
Da mesma forma, a permanente evolução da vida humana está sempre a gerar situações jurídicas não explicáveis, totalmente, com os antigos conceitos." ${ }^{102}$

O mesmo pode-se dizer acerca do conceito de poder de controle, o qual deve ser aprimorado diante de uma nova realidade de incipiente dispersão de capital no Brasil, pois, segundo os ensinamentos do Professor e Sociólogo Robert Henry Srour, após a Revolução Industrial ocorrida no Século XVIII, constata-se a existência de uma nova revolução, a Revolução Digital ocorrida no último quartel do Século XX.

A Revolução Digital deu início a uma era da informação ${ }^{103}$, em que a informação é divulgada através de um suporte eletrônico.

Nesta nova era, constata-se a existência de uma grande abertura comercial e, dessa maneira, de sujeição das empresas à competição internacional, dando lugar a empresas organizadas e direcionadas à obtenção de suas metas organizacionais com extrema habilidade, além de produzirem bens e serviços em grande escala, a um menor custo, mas de melhor qualidade,

O presente trabalho justamente verificará os elementos essenciais do conceito de poder de controle e as formas de seu exercício em companhias de capital aberto no Brasil para se verificar se há necessidade, ou não, de uma remodelação naquele conceito para atender à incipiente realidade de dispersão acionária brasileira.

\footnotetext{
102 COMPARATO, Fábio Konder; SAlOMÃO FILHO, Calixto. O Poder de Controle na Sociedade Anônimas. 4. ${ }^{\text {a }}$ edição. Rio de Janeiro: Forense, 2005, p. 106.

103 "Etimologicamente, informação é o processo que organiza a ação. Os dados, ao provocarem alguma intervenção por parte dos receptores, convertem-se em informação. Para os economistas, informação é redução ou remoção da incerteza, à medida que tornam mais seguras as decisões públicas ou privadas. Para os administradores, a informação é um insumo do processo de tomada de decisão, além de conferir às ações que dele se originam uma avaliação consciente. Em ambos os casos, a informação constitui um recurso que agrega valor a processos e a produtos." (SROUR, Robert Henry. Poder, Cultura e Ética nas Organizações. 3. ${ }^{a}$ edição. Rio de Janeiro: Elsevier, 2012, p. 10, nota de rodapé n. ${ }^{\circ}$ 14)
} 


\section{A SOCIEDADE POR AÇÕES NO BRASIL}

\subsection{EVOLUÇÃO HISTÓRICO-LEGISLATIVA DA COMPANHIA}

Embora o Decreto n. ${ }^{\circ}$ 575, de 10.01.1849 tenha sido a primeira legislação brasileira a tratar das sociedades anônimas, a mesma apenas possuía uma regulamentação para a incorporação de uma sociedade anônima, de modo que não trazia qualquer referência ao poder de controle ou ao acionista majoritário.

Após o Decreto n. ${ }^{\circ}$ 575/1849, foi promulgado o Código Comercial Brasileiro, Lei n. ${ }^{\circ}$ 556, de 25.06.1850, o qual passou a cuidar das sociedades anônimas nos arts. 295 a 299.

Contudo, a regulamentação trazida pelo Código Comercial era muito superficial e tratava apenas de alguns aspectos distintos das demais sociedades comerciais previstas naquele diploma legal.

Dentre os arts. 295 a 299, do Código Comercial, não havia nenhuma menção a poder de controle, tampouco a acionista majoritário, aspectos estes não tratados de maneira sistematizada naquele diploma legal.

Assim, poder-se-ia apenas extrair dos arts. 331 e $486^{104}$, do Código Comercial que as decisões tomadas pela maioria seriam impositivas à minoria, de forma que se poderia deduzir que exerceria o poder de controle o sócio ou sócios que detivessem a maioria das ações com direito a voto.

\footnotetext{
104 “Art. 331 - A maioria dos sócios não tem faculdade de entrar em operações diversas das convencionadas no contrato sem o consentimento unânime de todos os sócios. Nos mais casos todos os negócios sociais serão decididos pelo voto da maioria, computado pela forma prescrita no artigo $n^{o}$. 486." (BRASIL. Lei n. $^{\circ}$ 556, de 25 de junho de 1850. Código Comercial. Disponível em <http://www.planalto.gov.br/ccivil_03/leis/10556-1850.htm>. Acesso em 02.11.2014)

“Art. 486 - Nas parcerias ou sociedades de navios, o parecer da maioria no valor dos interesses prevalece contra o da minoria nos mesmos interesses, ainda que esta seja representada pelo maior número de sócios e aquela por um só. Os votos computam-se na proporção dos quinhões; o menor quinhão será contado por um voto; no caso de empate decidirá a sorte, se os sócios não preferirem cometer a decisão a um terceiro." (Idem, ibidem)
} 
Contudo, ao que parece, durante a vigência do Código Comercial, a caracterização do poder de controle não se limitava à detenção de ações correspondentes a uma participação majoritária, de forma que outros aspectos ínsitos ao poder de controle deveriam ser levados em conta para tanto, tal como será visto mais adiante no presente trabalho.

Em 04.11.1882, foi publicada a Lei n. $^{\circ} 3.150$, que trouxe uma regulamentação mais extensa e mais sistematizada sobre as sociedades anônimas.

Contudo, tal como as leis anteriores, a Lei n. ${ }^{\circ} 3.150 / 1882$ não trouxe uma disciplina sistemática do poder de controle ou do acionista controlador, limitando-se a indicar, em alguns artigos esparsos, a responsabilidade pessoal dos acionistas fundadores por atos praticados antes da constituição da companhia (art. 5. ${ }^{\circ}$ da Lei 3.150/1882) ${ }^{105}$, bem como que a decisão a ser tomada em assembleia geral seria tomada pela maioria dos sócios presentes (art. $15, \S 4 .^{\circ}$, da Lei n. $\left.{ }^{\circ} 3.150 / 1882\right)^{106}$.

Assim, das disposições da Lei n. ${ }^{\circ}$ 3.150/1882, presume-se deter o poder de controle os fundadores ou acionista investidor que detiver maioria nas deliberações sociais, ou seja, que conseguir determinar os rumos das deliberações por meio do exercício do direito de voto.

Após a Lei n. ${ }^{\circ} 3.150 / 1882$, foi promulgado o Decreto-lei n. ${ }^{\circ} 2.627$, de 26.09.1940, que trouxe nova regulamentação das sociedades anônimas.

105 “Art. 5\% Os actos anteriores á constituição legal da sociedade e ao preenchimento das formalidades dos $\S \S 4^{o}$ e $5^{\circ}$ do art. $3^{\circ}$ ficarão sob a responsabilidade dos seus fundadores ou administradores, salvo si, constituída a sociedade, a assembléa geral assumir a responsabilidade de taes actos.

São os fundadores solidariamente responsáveis aos interessados pelas perdas e damnos resultantes da inobservância das prescripções desta lei, relativas às condições e constituição das companhias. (Arts. $2^{\circ} e$ $3^{\circ}$ )" (BRASIL. Lei n. ${ }^{\circ} 3.150$, de 04 de novembro de 1882. Regula o estabelecimento de companhias e sociedades anônimas. Disponível em < http://www.planalto.gov.br/ccivil_03/Leis/LIM/LIM3150.htm>. Acesso em 02.11.2014)

106 "Art. 15. Haverá em cada anno uma assembléa geral dos accionistas, cuja reunião será fixada nos estatutos, e sempre annunciada 15 dias antes pela imprensa.

(...)

$\S 4^{o}$ Todavia, a assembléa geral, que deve deliberar sobre os casos dos arts. $3^{\circ}$ e $6^{o}$, para ser validamente constituída carece de um numero de accionistas que represente, pelo menos, dous terços do capital social.

Si nem na primeira, nem na segunda reunião, comparecer o numero de accionistas exigido neste paragrapho, se convocará terceira, com a declaração de que a assembléa poderá deliberar, qualquer que seja a somma do capital representado pelos presentes. Além dos annuncios, a convocação neste caso se fará por carta.

As deliberações da assembléa geral, tanto no caso deste paragrapho, como no do $\$ 2^{o}$, serão tomadas pela maioria dos socios presentes." (Idem, ibidem) 
Contudo, tal como as leis anteriores, ao Decreto-lei n. ${ }^{\circ}$ 2.627/1940 não regulou o poder de controle ou, ainda, a figura do acionista controlador, limitando-se a mencionar, em alguns dispositivos, a figura dos fundadores, aos quais, inclusive, era permitida a atribuição de vantagens particulares (art. 40, inciso IV, alínea ' $\mathrm{f}$ ' ${ }^{107}$ ), além de ser-lhes atribuída responsabilidade solidária pelo descumprimento dos preceitos legais acerca da constituição da companhia (art. $49^{108}$ ).

Desse modo, poder-se-ia extrair que, dentre os fundadores (ou, posteriormente, entre os acionistas investidores também), quem detivesse a maioria das ações votantes, deteria o poder de controle, visto que, conforme disposto no art. $94^{109}$, as decisões tomadas na assembleia geral eram tomadas por maioria absoluta.

Portanto, somente com a promulgação da Lei n. ${ }^{\circ}$ 6.404, de 15.12.1976, a figura do acionista controlador e, por consequência, do poder de controle (arts. 116, 116-A, 117 e $254-\mathrm{A}$ e, em sua redação original, o art. $254^{110}$ ) passaram a ter tratamento expresso e

107 “Art. 40. Na constituição da sociedade por subscrição pública, observar-se-ão os seguintes preceitos: (...) $I V$, o prospecto mencionará claramente: (...)f) as vantagens particulares, a que terão direito os fundadores ou terceiros, e o artigo do projeto dos estatutos que as regula;" (BRASIL. Decreto-lei n. 2.627 , de 26 de setembro de 1940. Dispõe sobre as sociedades por ações. Disponível em < http://www.planalto.gov.br/ccivil_03/decreto-lei/del2627.htm>. Acesso em 02.11.2014)

108 “Art. 49. Os fundadores, no caso de culpa ou dolo, respondem solidariamente pelo prejuízos resultantes da inobservância dos preceitos legais relativos à constituição da sociedade, bem como pelos que se originarem de atos ou operações anteriores."(Idem, ibidem)

109 "Art. 94. As deliberações da assembléia geral ressalvadas as exceções previstas na lei, são tomadas por maioria absoluta de votos, não se computando os votos em branco." (Idem, ibidem)

110 “Art. 116. Entende-se por acionista controlador a pessoa, natural ou jurídica, ou o grupo de pessoas vinculadas por acordo de voto, ou sob controle comum, que:

a) é titular de direitos de sócio que lhe assegurem, de modo permanente, a maioria dos votos nas deliberações da assembléia-geral e o poder de eleger a maioria dos administradores da companhia; $e$

b) usa efetivamente seu poder para dirigir as atividades sociais e orientar o funcionamento dos órgãos da companhia.

Parágrafo único. $O$ acionista controlador deve usar o poder com o fim de fazer a companhia realizar o seu objeto e cumprir sua função social, e tem deveres e responsabilidades para com os demais acionistas da empresa, os que nela trabalham e para com a comunidade em que atua, cujos direitos e interesses deve lealmente respeitar e atender.

Art. 116-A. O acionista controlador da companhia aberta e os acionistas, ou grupo de acionistas, que elegerem membro do conselho de administração ou membro do conselho fiscal, deverão informar imediatamente as modificações em sua posição acionária na companhia à Comissão de Valores Mobiliários e às Bolsas de Valores ou entidades do mercado de balcão organizado nas quais os valores mobiliários de emissão da companhia estejam admitidos à negociação, nas condições e na forma determinadas pela Comissão de Valores Mobiliários.(Incluído pela Lei $n^{o}$ 10.303, de 2001)

Art. 117. O acionista controlador responde pelos danos causados por atos praticados com abuso de poder.

$\$ 1^{\circ}$ São modalidades de exercício abusivo de poder:

a) orientar a companhia para fim estranho a objeto social ou lesivo ao interesse nacional, ou levá-la a favorecer outra sociedade, brasileira ou estrangeira, em prejuízo da participação dos acionistas minoritários nos lucros ou no acervo da companhia, ou da economia nacional; 
sistemático, trazendo, inclusive, o conceito de acionista controlador, suas responsabilidades e suas obrigações quando da venda do poder de controle.

b) promover a liquidação de companhia próspera, ou a transformação, incorporação, fusão ou cisão da companhia, com o fim de obter, para si ou para outrem, vantagem indevida, em prejuízo dos demais acionistas, dos que trabalham na empresa ou dos investidores em valores mobiliários emitidos pela companhia;

c) promover alteração estatutária, emissão de valores mobiliários ou adoção de políticas ou decisões que não tenham por fim o interesse da companhia e visem a causar prejuízo a acionistas minoritários, aos que trabalham na empresa ou aos investidores em valores mobiliários emitidos pela companhia;

d) eleger administrador ou fiscal que sabe inapto, moral ou tecnicamente;

e) induzir, ou tentar induzir, administrador ou fiscal a praticar ato ilegal, ou, descumprindo seus deveres definidos nesta Lei e no estatuto, promover, contra o interesse da companhia, sua ratificação pela assembléia-geral;

f) contratar com a companhia, diretamente ou através de outrem, ou de sociedade na qual tenha interesse, em condições de favorecimento ou não equitativas;

g) aprovar ou fazer aprovar contas irregulares de administradores, por favorecimento pessoal, ou deixar de apurar denúncia que saiba ou devesse saber procedente, ou que justifique fundada suspeita de irregularidade.

h) subscrever ações, para os fins do disposto no art. 170, com a realização em bens estranhos ao objeto social da companhia. (Incluída dada pela Lei $n^{\circ}$ 9.457, de 1997)

$\S 2^{\circ}$ No caso da alínea e do $\S 1^{o}$, o administrador ou fiscal que praticar o ato ilegal responde solidariamente com o acionista controlador.

$\S 3^{\circ} O$ acionista controlador que exerce cargo de administrador ou fiscal tem também os deveres $e$ responsabilidades próprios do cargo." (BRASIL. Lei n. ${ }^{\circ}$ 6.404, de 15 d dezembro de 1976. Dispõe sobre as sociedades por ações. Disponível em <http://www.planalto.gov.br/ccivil_03/leis/16404consol.htm>. Acesso em: 02.11.2014)

“Art. 254. A alienação do controle da companhia aberta dependerá de prévia autorização da Comissão de Valores Mobiliários.(Revogado pela Lei $n^{\circ}$ 9.457, de 1997)

$\$ 1^{\circ}$ A Comissão de Valores Mobiliários deve zelar para que seja assegurado tratamento igualitário aos acionistas minoritários, mediante simultânea oferta pública para aquisição de ações.(Revogado pela Lei $n^{o}$ 9.457, de 1997)

$\S 2^{\circ}$ Se o número de ações ofertadas, incluindo as dos controladores ou majoritários, ultrapassar o máximo previsto na oferta, será obrigatório o rateio, na forma prevista no instrumento da oferta pública.(Revogado pela Lei $n^{\circ} 9.457$, de 1997)

$\S 3^{\circ}$ Compete ao Conselho Monetário Nacional estabelecer normas a serem observadas na oferta pública relativa à alienação do controle de companhia aberta “.(Revogado pela Lei $n^{\circ} 9.457$, de 1997)

“ Art. 254-A. A alienação, direta ou indireta, do controle de companhia aberta somente poderá ser contratada sob a condição, suspensiva ou resolutiva, de que o adquirente se obrigue a fazer oferta pública de aquisição das ações com direito a voto de propriedade dos demais acionistas da companhia, de modo a lhes assegurar o preço no mínimo igual a $80 \%$ (oitenta por cento) do valor pago por ação com direito a voto, integrante do bloco de controle.

§ 10 Entende-se como alienação de controle a transferência, de forma direta ou indireta, de ações integrantes do bloco de controle, de ações vinculadas a acordos de acionistas e de valores mobiliários conversíveis em ações com direito a voto, cessão de direitos de subscrição de ações e de outros títulos ou direitos relativos a valores mobiliários conversíveis em ações que venham a resultar na alienação de controle acionário da sociedade

\$2o A Comissão de Valores Mobiliários autorizará a alienação de controle de que trata o caput, desde que verificado que as condições da oferta pública atendem aos requisitos legais.

§ 3o Compete à Comissão de Valores Mobiliários estabelecer normas a serem observadas na oferta pública de que trata o caput.

$\S 4$ o $O$ adquirente do controle acionário de companhia aberta poderá oferecer aos acionistas minoritários a opção de permanecer na companhia, mediante o pagamento de um prêmio equivalente à diferença entre o valor de mercado das ações e o valor pago por ação integrante do bloco de controle.

§ 5 o (VETADO.)" (Idem, ibidem) 
Será justamente este conceito de poder de controle, extraído do conceito de acionista controlador constante do art. 116 da Lei n..$^{\circ}$ 6.404/76, que será estudado no presente trabalho diante de um cenário de dispersão acionária, o que requer, previamente, uma análise do conceito de sociedade anônima e de suas principais características no âmbito do Direito Societário. 


\subsection{A SOCIEDADE POR AÇÕES NO DIREITO SOCIETÁRIO BRASILEIRO}

Inicialmente, cumpre analisar o conceito de atividade empresarial, que, nos termos do disposto no art. 966, do Código Civil $^{111}$, consiste no exercício profissional e habitual de atividade econômica, por meio de um complexo de pessoas e de bens de produção devidamente organizados, para produzir bens e/ou serviços destinados à circulação no mercado, sempre visando à lucratividade.

A atividade empresarial pode ser exercida por meio de sociedade, ou seja, através de uma pessoa jurídica constituída através da celebração de um contrato de sociedade, tal como previam o art. 300 do Código Comercial de 1850 e o art. 1.363 do Código Civil de 1916, o que, aliás, foi previsto também no art. 981 do Código Civil de $2002^{112}$.

Assim, amalgamando as disposições legais acima indicadas, podemos conceituar a sociedade como sendo o contrato resultante do acordo de vontades de duas ou mais pessoas de natureza plurilateral, que conjugam seus esforços para lograr fim comum e contribuem para a formação patrimonial da pessoa jurídica, seja através de contribuição pecuniária, seja por meio de contribuição em bens, proporcionando meios para viabilizar o

\footnotetext{
111 “Art. 966. Considera-se empresário quem exerce profissionalmente atividade econômica organizada para a produção ou a circulação de bens ou de serviços.

Parágrafo único. Não se considera empresário quem exerce profissão intelectual, de natureza científica, literária ou artística, ainda com o concurso de auxiliares ou colaboradores, salvo se o exercício da profissão constituir elemento de empresa." (BRASIL. Lei n. ${ }^{\circ}$ 10.406, de 10 de janeiro de 2002. Institui o Código Civil. Disponível em < http://www.planalto.gov.br/ccivil_03/leis/2002/110406.htm>. Acesso em 02.11.2014)

112 "Art. 300. O contrato de qualquer sociedade comercial só pode provar-se por escritura publica ou particular; salvo nos casos dos arts. $304 \quad$ e 325. Nenhuma prova testemunhal será admitida contra e além do conteúdo no instrumento do contrato social." (BRASIL. Lei n. ${ }^{\circ}$ 556, de 25 de junho de 1850. Código Comercial. Disponível em <http://www.planalto.gov.br/ccivil_03/leis/10556-1850.htm>. Acesso em 02.11.2014.)

"Art. 1.363. Celebram contrato de sociedade as pessoas que mutuamente se obrigam a combinar seus esforços ou recursos, para lograr fins comuns." (BRASIL. Lei n. ${ }^{\circ}$ 3.071, de 01 de janeiro de 1916. Código Civil dos Estados Unidos do Brasil. Disponível em < http://www.planalto.gov.br/ccivil_03/leis/13071.htm>. Acesso em 02.11.2014)

"Art. 981. Celebram contrato de sociedade as pessoas que reciprocamente se obrigam a contribuir, com bens ou serviços, para o exercício de atividade econômica e a partilha, entre si, dos resultados." (BRASIL. Lei n. ${ }^{\circ}$ 10.406, de 10 de janeiro de 2002. Institui o Código Civil. Disponível em < http://www.planalto.gov.br/ccivil_03/leis/2002/110406.htm>. Acesso em 02.11.2014)
} 
exercício coletivo ${ }^{113}$ de atividade econômica lícita e a consequente partilha dos resultados, tratando, desse modo, da constituição, da regulação e da extinção de uma relação jurídica de natureza patrimonial ${ }^{114}$.

Dentre as sociedades empresárias, há a sociedade anônima que é uma sociedade de capitais, cujo capital social é divido em ações, sendo a responsabilidade patrimonial dos sócios limitada ao valor das ações subscritas ou adquiridas, além de seu objeto ter de ser de natureza empresarial (conforme dispõe o art. $2 .^{\circ}, \S 1 .^{\circ}$, da Lei n. ${ }^{\circ}$ $\left.6.404 / 76^{115}\right)$, apresentando, ainda, uma estrutura hierarquizada e complexa de administração e deliberação determinada pelo próprio legislador, na qual o poder empresarial $^{116}$ é exercido pelo acionista controlador, além de poder emitir valores mobiliários a serem negociados no mercado de valores mobiliários ${ }^{117}$, caso seja da modalidade de capital social aberto.

Analisando-se a evolução histórico-legislativa das sociedades anônimas, pode-se constatar que elas foram estruturadas para atender à demanda do mercado consumidor e, consequentemente, terem uma produção em larga escala, em massa, o que passou a requerer, obviamente, o acesso a grandes volumes de capitais justamente para financiar a produção em larga escala, acesso este não somente através dos recursos do

\footnotetext{
${ }^{113}$ Consoante o jurista italiano Antonio Brunetti, “(...) la società è la forma tipica di esercizio colletivo di un'attività economica produttiva e normalmente di un'attività durevolmente organizzat a impresa." (In: Trattato del diritto delle società. Vol. I. Milano: Giuffrè, 1948, p. 97) Tradução livre: “(...) a sociedade é a forma típica de exercício coletivo de uma ativadade econômica produtiva e normalmente de uma atividade duradouramente organizada ao exercício da empresa."

${ }^{114}$ Vide a redação do art. 1.321 do Código Civil Italiano: "Art. 1321 Nozione. Il contratto è l'accordo di due o più parti per costituire, regolare o estinguere tra loro un rapporto giuridico patrimoniale." (Tradução livre: "Art. 1321 Noção. O contrato é o acordo de duas ou mais partes para constituir, regular ou extinguir entre elas uma relação jurídica patrimonial.") Disponível em < http://www.rcscuola.it/disciplina/ccivile.pdf $>$. Acesso em 16.09.2012.

115 “Art. $2^{\circ}$ Pode ser objeto da companhia qualquer empresa de fim lucrativo, não contrário à lei, à ordem pública e aos bons costumes.

$\$ 1^{\circ}$ Qualquer que seja o objeto, a companhia é mercantil e se rege pelas leis e usos do comércio." (BRASIL. Lei n. ${ }^{\circ}$ 6.404, de 15 d dezembro de 1976. Dispõe sobre as sociedades por ações. Disponível em <http://www.planalto.gov.br/ccivil_03/leis/16404consol.htm>. Acesso em: 02.11.2014)

116 "Poder empresarial é a modalidade de poder próprio do grupo social da empresa e consiste na capacidade de causar, determinar ou alterar a atividade da empresa - tanto interna (produção de serviços econômicos) quanto externa." (LAMY FILHO, Alfredo e PEDREIRA, José Luiz Bulhões. Direito das Companhias. Vol. I. Rio de Janeiro: Forense, 2009, p. 65)

117 "Nas companhias coloniais já se delineiam as características fundamentais hoje peculiares da sociedade anônima e que a distinguem entre as várias espécies de sociedade: responsabilidade limitada dos sócios e divisão do capital em ações, isto é, possiblidade de serem, as participações dos vários sócios, corporizadas em títulos facilmente circuláveis; a pessoa do sócio é, destarte, indiferente à caracterização jurídica da sociedade." (ASCARELLI, Tullio. Problemas das Sociedades Anônimas e Direito Comparado. Campinas: Bookseller, 2001, p. 452)
} 
mercado financeiro, mas principalmente através do mercado de capitais com o lançamento de valores mobiliários ${ }^{118}$.

Por meio deste mecanismo de socorrer-se do mercado de valores mobiliários para a captação de recursos a serem investidos na atividade produtiva, o modelo de sociedade anônima, inclusive, evita o pagamento do spread bancário, permitindo-lhe o acesso a recursos praticamente isentos de custos de intermediação.

Dentro da perspectiva da Lei n. ${ }^{\circ}$ 6.404/76, as sociedades anônimas foram estruturadas para servir às grandes empresas, isto é, seu modelo econômico-jurídico foi elaborado em uma época em que, na economia brasileira, as empresas privadas sofriam de uma grave retração em contraposição à hipertrofia das empresas públicas, momento em que, inclusive, praticamente o mercado de valores mobiliários era demasiadamente subdesenvolvido.

Assim, o anteprojeto da atual Lei n. ${ }^{\circ} 6.404 / 76^{119}$ tinha por objetivo precípuo a estruturação de um modelo econômico-jurídico de sociedade anônima destinado às empresas grandes, criando-se estrutura e mecanismos legais para que as empresas possam recorrer ao mercado de valores mobiliários como forma de obter acesso ao capital de um modo menos custoso que a via bancária.

Aliás, a exposição de motivos do anteprojeto da Lei n. ${ }^{\circ}$ 6.404/76 indicava explicitamente que dentre os seus objetivos estava o fortalecimento do mercado de capitais brasileiro e a criação de uma estrutura econômico-jurídica moderna de sociedade

\footnotetext{
${ }^{118}$ A propósito, segundo Vera Helena de Mello Franco e Rachel Sztajn: "A sociedade anônima, dotada de capacidade ilimitada para atrair recursos financeiros, com a correlata possibilidade de limitar e dispersar os riscos decorrentes do exercício do empreendimento, foi o modelo jurídico societário adequado para prover a essa necessidade de grandes volumes de capitais. (...) E foi o modelo jurídico adequado para prover essa necessidade porque, dentre os tipos societários conhecidos, é a única apta a captar diretamente a poupança popular, concentrando os recursos financeiros obtidos de molde a concretizar os investimentos propostos. Para tanto emite títulos que coloca no mercado, oferecendo-os àqueles que, com excesso de poupança (agentes econômicos superavitários), buscam alternativas atraentes de investimentos no longo prazo." (In: Direito Empresarial II. 2. ${ }^{a}$ edição. São Paulo: Revista dos Tribunais, 2009, p. 36 - 37).

${ }^{119}$ Em relação às críticas feitas ao anteprojeto, como as mesmas extrapolam objetivo do presente trabalho, sugerimos a leitura do livro de Modesto Carvalhosa, A Nova Lei das Sociedades Anônimas - Seu Modelo Econômico.
} 
empresarial destinada às grandes empresas, especialmente a sociedade anônima de capital aberto $^{120}$.

A propósito, Tullio Ascarelli ensinava que os dois princípios fundamentais da sociedade anônima, quais sejam o da responsabilidade limitada e o da divisão do capital social em ações, "coadunam-se com a exigência econômica fundamental a que atende a sociedade anônima, a saber: a constituição de um instrumento que visa a facilitar o espírito de empreendimento e, ainda, a mobilizar economias de vastas camadas da população; com o objetivo de 'coletivização' do financiamento, de tal modo que, no interesse geral, possa ser incrementado o progresso industrial. Tudo para que possa ser criada a grande indústria com suas elevadas inversões em bens instrumentais, os quais, por sua vez exigem capitais de vulto que requerem a cooperação de muitos indivíduos, proporcionando, a seu turno, a possibilidade de cooperar na constituição de uma empresa industrial e participar nos lucros respectivos, mesmo àqueles que não poderiam fazer direta e pessoalmente."

Contudo, como a sociedade empresarial destina-se ao exercício profissional de atividade econômica por meio da organização de um complexo de pessoas e de bens de produção, resulta que a sociedade anônima requer a existência de um sócio condutor da política, da administração e da execução das atividades empresariais para a consecução de seu objetivo social e de sua função social, figura esta centralizada no acionista controlador.

Analisando o teor da Lei n. ${ }^{\circ}$ 6.404/76, constata-se que houve um tratamento específico acerca do acionista controlador, não só apresentando os caracteres necessários para caracterizar o controlador (art. 116 da Lei n. ${ }^{\circ} 6.404 / 76^{122}$ ), mas também dando um tratamento acerca de suas responsabilidades (arts.116-A e 117 da Lei n. ${ }^{\circ} 6.404 / 76^{123}$ ).

\footnotetext{
${ }^{120}$ Veja a propósito a relevância do instituto da sociedade anônima, segundo Alfredo Lamy Filho e José Luiz Bulhões Pedreira: "Instrumento admirável, de capacidade ilimitada para mobilizar capitais e congregar técnicas e pessoas na consecução de um objetivo o comum, tornou viáveis os gigantescos empreendimentos que caracterizam o estágio de desenvolvimento econômico dos nossos dias."(In: A Lei das S.A. Rio de Janeiro: Renovar, 1992, p. 27)

121 ASCARELlI, Tullio. Problemas das Sociedades Anônimas e Direito Comparado. Campinas: Bookseller, 2001, p. $461-462$.

122 "Art. 116. Entende-se por acionista controlador a pessoa, natural ou jurídica, ou o grupo de pessoas vinculadas por acordo de voto, ou sob controle comum, que:

a) é titular de direitos de sócio que lhe assegurem, de modo permanente, a maioria dos votos nas deliberações da assembléia-geral e o poder de eleger a maioria dos administradores da companhia; $e$
} 
Consoante Modesto Carvalhosa, o anteprojeto da Lei n. ${ }^{\circ}$ 6.404/76, refletia "a ideologia da dominação do grupo controlador sobre os demais segmentos sociais internos e externos da companhia. Segundo o anteprojeto, cabe aos controladores todas as prerrogativas na condução da política, administração e propriedade das companhias."

Justamente por isso, a Lei n. ${ }^{\circ}$ 6.404/76 trouxe uma disciplina jurídica do acionista controlador, que será estudada com maior profundidade adiante.

b) usa efetivamente seu poder para dirigir as atividades sociais e orientar o funcionamento dos órgãos da companhia.

Parágrafo único. $O$ acionista controlador deve usar o poder com o fim de fazer a companhia realizar o seu objeto e cumprir sua função social, e tem deveres e responsabilidades para com os demais acionistas da empresa, os que nela trabalham e para com a comunidade em que atua, cujos direitos e interesses deve lealmente respeitar e atender." (BRASIL. Lei n. ${ }^{\circ}$ 6.404, de $15 \mathrm{~d}$ dezembro de 1976. Dispõe sobre as sociedades por ações. Disponível em <http://www.planalto.gov.br/ccivil_03/leis/16404consol.htm>. Acesso em: 02.11.2014)

123 “Art. 116-A. O acionista controlador da companhia aberta e os acionistas, ou grupo de acionistas, que elegerem membro do conselho de administração ou membro do conselho fiscal, deverão informar imediatamente as modificações em sua posição acionária na companhia à Comissão de Valores Mobiliários $e$ às Bolsas de Valores ou entidades do mercado de balcão organizado nas quais os valores mobiliários de emissão da companhia estejam admitidos à negociação, nas condições e na forma determinadas pela Comissão de Valores Mobiliários.

Art. 117. O acionista controlador responde pelos danos causados por atos praticados com abuso de poder.

$\$ 1^{\circ}$ São modalidades de exercício abusivo de poder:

a) orientar a companhia para fim estranho ao objeto social ou lesivo ao interesse nacional, ou levá-la a favorecer outra sociedade, brasileira ou estrangeira, em prejuízo da participação dos acionistas minoritários nos lucros ou no acervo da companhia, ou da economia nacional;

b) promover a liquidação de companhia próspera, ou a transformação, incorporação, fusão ou cisão da companhia, com o fim de obter, para si ou para outrem, vantagem indevida, em prejuízo dos demais acionistas, dos que trabalham na empresa ou dos investidores em valores mobiliários emitidos pela companhia;

c) promover alteração estatutária, emissão de valores mobiliários ou adoção de políticas ou decisões que não tenham por fim o interesse da companhia e visem a causar prejuízo a acionistas minoritários, aos que trabalham na empresa ou aos investidores em valores mobiliários emitidos pela companhia;

d) eleger administrador ou fiscal que sabe inapto, moral ou tecnicamente;

e) induzir, ou tentar induzir, administrador ou fiscal a praticar ato ilegal, ou, descumprindo seus deveres definidos nesta Lei e no estatuto, promover, contra o interesse da companhia, sua ratificação pela assembléia-geral;

f) contratar com a companhia, diretamente ou através de outrem, ou de sociedade na qual tenha interesse, em condições de favorecimento ou não equitativas;

g) aprovar ou fazer aprovar contas irregulares de administradores, por favorecimento pessoal, ou deixar de apurar denúncia que saiba ou devesse saber procedente, ou que justifique fundada suspeita de irregularidade.

h) subscrever ações, para os fins do disposto no art. 170, com a realização em bens estranhos ao objeto social da companhia. (Incluída dada pela Lei $n^{\circ} 9.457$, de 1997)

$\S 2^{o}$ No caso da alínea e do $\$ 1^{o}$, o administrador ou fiscal que praticar o ato ilegal responde solidariamente com o acionista controlador.

$\S 3^{\circ} \mathrm{O}$ acionista controlador que exerce cargo de administrador ou fiscal tem também os deveres $e$ responsabilidades próprios do cargo." (Idem, ibidem)

${ }^{124}$ In: CARVAlHOSA, Modesto. A Nova Lei das Sociedades Anônimas - Seu Modelo Econômico. 2. edição. Rio de Janeiro: Paz e Terra, 1977, p. 25. 
Portanto, à guisa de conclusão parcial, pode-se afirmar que as sociedades anônimas, hoje, no âmbito do Direito Societário, destinam-se, primordialmente, a servir de estrutura econômico-jurídica para as sociedades empresariais de grande porte, especialmente as sociedades anônimas de capital aberto, permitindo, assim, uma grande mobilização de capitais sem, necessariamente, ter de se socorrer do financiamento bancário e, consequentemente, sem ter de incorrer nos custos da intermediação bancária. 


\subsection{AS PRINCIPAIS CARACTERÍSTICAS DAS COMPANHIAS NO ÂMBITO DO NOVO MERCADO DA BM\&FBOVESPA ${ }^{125}$}

Como visto acima, com a estrutura legislativa criada pela promulgação da Lei n. ${ }^{\circ}$ 6.385/76 e da Lei n. ${ }^{\circ}$ 6.404/76, o Brasil visou abarcar a grande empresa voltada a grandes empreendimentos, que constituem a base da economia de mercado, dando início, assim, à formação de uma estrutura legal para a macroempresa.

Não obstante, o mercado de valores mobiliários brasileiro continuou sendo pouco desenvolvido, o que, segundo estudos efetuados, estava diretamente relacionado à parca proteção dos acionistas minoritários e à fraca governança corporativa da sociedade anônima brasileira.

Como reação ao tolhimento de direitos dos minoritários na época das privatizações em 1997, percebe-se o início de uma atividade autorregulatória ${ }^{126}$ para as sociedades anônimas, especialmente no que diz respeito à adoção de práticas de governança corporativa.

Foi assim que, por exemplo, em 1999 surgiram o $1^{\text {o }}$ Código de Autorregulação da Associação Nacional de Bancos de Investimentos e o Código de Melhores Práticas de Governança Corporativa do IBGC (Instituto Brasileiro de Governança Corporativa), seguindo-se, em 2000, pela criação dos níveis de governança corporativa pela BM\&FBovespa e, em 2002, pela Cartilha sobre Governança Corporativa da Comissão de Valores Mobiliários.

\footnotetext{
125 Apenas a título de esclarecimento, no presente trabalho, quando houver referência à Bovespa, isto significará que o ato ou fato refere-se a um momento cronológico anterior à fusão da Bovespa com a BM\&F. Quando o ato ou fato for posterior à fusão das bolsas, então se adota a denominação BM\&FBovespa.

126 "O lançamento do Novo Mercado decorreu do reconhecimento pela Bolsa de Valores de São Paulo de que a reforma da Lei das S.A. seria um caminho longo, difícil e com muitos obstáculos para chegar-se a um modelo regulatório que oferecesse proteção adequada aos investidores. Foi, portanto, uma iniciativa de autorregulação, com o objetivo de contornar a dificuldade de buscar-se uma solução baseada em reforma da lei societária. O fato de a adesão aos segmentos diferenciados de listagem ser facultativa eliminou a eventual resistência das companhias já listadas. Essa visão mostrou-se correta, na medida em que a Lei $n .^{o}$ 10.303/2001, editada um ano após o lançamento do Novo Mercado, ficou muito aquém do esperado em termos de regras de proteção aos investidores." (MUNHOZ, Eduardo Secchi. Aquisição de Controle na Sociedade Anônima. São Paulo: Saraiva, 2013, p. 66)
} 
Esta atividade autorregulatória apresentou uma tríplice finalidade, qual seja (a) atender aos interesses da comunidade ao estipular práticas maximizadoras do bem-estar da sociedade, (b) atender aos interesses dos acionistas ao incentivar a adoção de práticas estimuladoras de maior retorno financeiro aos acionistas e (c) maximizar o valor de mercado das ações ao estimular a adoção de práticas de governança corporativa, de modo a obter um maior desenvolvimento e fortalecimento do mercado de valores mobiliários para propiciar o financiamento dos agentes econômicos privados via mercado de valores mobiliários.

Assim, passou-se a perceber que também no Brasil havia uma relação direta entre a qualidade da governança corporativa e a facilidade de captação de recursos no mercado, de forma que os standards de governança corporativa passaram a ser vistos como estimuladores da dispersão acionária e da valorização dos valores mobiliários, tendo como consequência direta o desenvolvimento do mercado de valores mobiliários. ${ }^{127}$

É justamente neste ambiente que a Bovespa lançou os níveis de governança corporativa, enquanto um conjunto de regras e diretrizes sintetizadoras de boas práticas de governo de empresa, tanto em suas relações internas, quanto em suas relações externas, de modo a disciplinar (a) o relacionamento entre as partes envolvidas na empresa, estabelecendo um sistema de relação e um conjunto de direitos relativos não só às relações entre acionistas (majoritário e minoritários), mas também entre acionistas e administradores, (b) as estruturas de poder-função da empresa, incluindo o sistema pelo qual a empresa é dirigida, controlada e fiscalizada, estabelecendo, assim, um sistema de governo e de estruturas do poder dentro de uma empresa e (c) sistema de valores e de padrões de comportamento fundados, basicamente, em quatro pilares: senso de justiça no trato dos acionistas minoritários (fairness), na plena informação ou transparência das informações da empresa (full disclosure), na prestação responsável de contas (accountability) e no cumprimento do sistema jurídico (compliance).

\footnotetext{
${ }^{127}$ Nesse sentido é o estudo desenvolvido por José Roberto Mendonça de Barros et al., “O tradicional preconceito em relação ao mercado de capitais no Brasil vem sendo substituído por uma visão mais moderna que valoriza sua importância como fonte de financiamento da economia e, consequentemente, vê no seu desenvolvimento condição sine qua non para a retomada do crescimento sustentado." (In: BARROS, José Roberto Mendonça de et al. Desafios e Oportunidades para o Mercado de Capitais Brasileiro. São Paulo: $\quad$ Bovespa, $\quad 2000, \quad$ p. $\quad 8 . \quad$ Disponível $\quad \mathrm{em}<$ http://www.bmfbovespa.com.br/Pdf/mercado_capitais_desafios.pdf >. Acesso em 10.02.2013)
} 
Assim, conforme exposto por Arnoldo Wald ${ }^{128}$, a adoção das práticas de governança corporativa equivale à instituição do Estado de Direito dentro da Sociedade Anônima, com as finalidades de (a) definir a posição da administração e os princípios a serem seguidos por ela na proteção e atendimento dos interesses dos acionistas, (b) proporcionar mudanças institucionais, de forma a permitir a solução de problemas da empresa e, assim, atingir um melhor desempenho em suas atividades econômicas e (c) obter maior eficiência na alocação de recursos e, consequentemente, gerar um valor agregado à empresa com reflexos no preço dos títulos e valores mobiliários negociados pela empresa, atraindo mais investidores.

Dentre as diversas práticas de governança corporativa adotadas e/ou propostas pelos principais documentos estimuladores de sua adoção, podemos indicar, exemplificativamente, as seguintes: a) distinção entre as figuras dos diretores e dos administradores, sendo que estes elegem e fiscalizam aqueles; b) preferência pela ocupação dos cargos de Presidente do Conselho e de Diretor-Geral por pessoas distintas; c) criação de um sistema de adequada proteção dos acionistas minoritários, permitindo-lhes a participação na gestão da empresa; d) existência de controle interno por meio da atuação do Conselho de Administração, do Conselho Fiscal e por meio de Comitês; e) existência de controle externo a ser exercido pela atuação da Comissão de Valores Mobiliários e, preferencialmente, pela utilização da arbitragem.

Dessa maneira, estas transformações tiveram como ponto fundamental a utilização do instrumento da governança corporativa como alavanca para o desenvolvimento do mercado de capitais, de modo a atribuir uma maior valorização às empresas brasileiras, conferir maior segurança aos investidores e proporcionar uma maior captação de recursos no mercado de valores mobiliários a um custo inferior se comparado aos custos de um financiamento bancário, bem como agregar valor aos títulos e valores mobiliários pela adoção das práticas de governança corporativa.

\footnotetext{
${ }^{128}$ WALD, Arnoldo. O Governo das Empresas. In: Revista de Direito Bancário, do Mercado de Capitais e da Arbitragem. São Paulo: Revista dos Tribunais, Ano 5, n. ${ }^{\circ}$ 15, Jan./Mar. de 2002.
} 
Nesta ambiente, os níveis de governança corporativa criados pela Bovespa $^{129}$ serviram como fator autorregulatório indutor do desenvolvimento do mercado de valores mobiliários brasileiro, ao impor a adoção das práticas de governança corporativa mais rigorosas por meio contratual às empresas ingressantes no Novo Mercado, favorecendo a dispersão do capital.

Desse modo, as sociedades anônimas listadas no Novo Mercado são obrigadas contratualmente a adotar diversos mecanismos, que tentam atribuir-lhes maior valorização no mercado de valores mobiliários.

Em síntese, os mecanismos a serem adotados pelas companhias listadas fundam-se, basicamente, $(\boldsymbol{i})$ na concessão de uma maior participação dos acionistas nas deliberações sociais, ao obrigá-las a adotar o princípio do one share, one vote e dar ênfase na emissão somente de ações ordinárias com direito a voto, (ii) reconhecimento do tag along de $100 \%$ (cem por cento) aos minoritários, (iii) imposição de regras de maior transparência e maior informação aos acionistas e ao próprio mercado (full disclosure) e (iv) adoção obrigatória do procedimento arbitral para a solução de conflitos societários.

Consoante o regulamento do Novo Mercado, as sociedades anônimas devem:

a) Apresentar um free floating mínimo de $25 \%$ (vinte e cinco por cento);

b) Realizar ofertas públicas que favoreçam à dispersão acionária;

c) Prestar informações relevantes aos acionistas e ao próprio mercado, melhorando, inclusive, a qualidade e a transparência das informações;

\footnotetext{
129 "Com base a análise das discussões sobre governança corporativa pode-se constatar que a Bovespa procurou lastrear os segmentos de listagem com regras menos controvertidas, como a independência da administração. Em que pesem as dificuldades para a implementação mercadológica e política de tais mercados, não se há como deixar de apontar para regras importantes de governança corporativa que não foram expostas nos regulamentos como a existência de administradores independentes, remuneração dos membros do conselho de administração frente à diretoria, organização de comitês para a execução dos trabalhos no conselho de administração, entre muitas outras. Não utilizou ainda a técnica da informação, onde questões mais controvertidas da governança corporativa poderiam deixar de ser aplicadas de forma cogente, mas com a obrigação da companhia explicitar ao mercado o não cumprimento com determinadas regras ou mesmo as razões para deixar de observar determinadas regras." (LAUTENSCHLEGER JÚNIOR, Nilson. Os Desafios Propostos pela Governança Corporativa ao Direito Empresarial Brasileiro. São Paulo: Malheiros, 2005, p. 117 - 118)
} 
d) Adoção de normas e práticas internacionais de contabilidade, tais como IAS - International Accounting Standards e US GAAP - United States Generally Accepted Accounting Principles;

e) Previsão de mandatos unificados aos administradores;

f) Reconhecimento de um tag along de $100 \%$ (cem por cento) em casos de alienação do controle;

g) Concessão de direito de voto aos preferencialistas em certas espécies de deliberações e, para as companhias listadas no Novo Mercado, permissão de emissão de apenas ações ordinárias com direito a voto (one share, one vote); e

h) Adesão à Câmara de Arbitragem para a solução dos litígios societários.

Com a adoção destas diretrizes de natureza autorregulatória, percebe-se que, no Brasil, inicia-se um movimento de valorização do ativismo dos acionistas, de modo a permitir que todos participem das deliberações ao impor às companhias listadas no Novo Mercado a concessão de direito a voto a todos os acionistas e a emissão de ações ordinárias apenas, ou seja, em suma visa ao tratamento mais justo e equânime dos acionistas (fairness).

Trata-se de nítida concessão de maior proteção aos acionistas minoritários e de um aumento da democratização nas atividades interna corporis da companhia, ao estruturar o exercício da função-poder de gestão da companhia e, ainda regular, o relacionamento entre os diversos interesses envolvidos na companhia, especialmente, mas não exclusivamente, entre os acionistas minoritários e o acionista controlador e a administração.

Além disso, impõe-se às companhias a adoção de práticas tendentes à plena informação com maior transparência aos acionistas e ao próprio mercado, propagando princípios éticos na condução dos negócios empresariais com plena responsabilidade (accountability) em caso de descumprimento das normas jurídicas (compliance) e 
induzindo-as à adoção de regras e diretrizes contábeis internacionais como forma de permitir uma análise mais facilitada por interessados estrangeiros, que podem avaliar a lisura da companhia no desempenho de suas atividades comerciais e administrativas.

As normas autorregulatórias acabam, também, preparando as companhias aderentes a uma atuação no mercado internacional, ao induzir à uniformização das normas contábeis e, por consequência, à dissipação das discrepâncias contábeis que as normas contábeis locais podem produzir em comparação aos padrões internacionais ${ }^{130}$.

Portanto, percebe-se que, no âmbito do Novo Mercado, as sociedades anônimas assumem características que denotam uma companhia mais democrática em suas atividades internas, mais ética, justa e transparente ${ }^{131}$, habilitando-as a provocar o desenvolvimento do mercado de valores mobiliários e à concessão de maior liquidez às próprias companhias.

\footnotetext{
130 "Um dos fatos mais reconhecidos da economia global é a internacionalização do mercado de capitais, mediante o fluxo transnacional contínuo e cada vez mais rápido de vultosos recursos financeiros, pelos quais competem acirradamente empresas e países.

Para analistas, investidores, reguladores, profissionais e demais stakeholders do crescente mercado global de capitais, a harmonização internacional das normas contábeis é prioridade urgente e inquestionável. Assim, a partir de 2006, 92 países já possuem suas normas harmonizadas conforme os padrões internacionais de contabilidade (International Financial Reporting Standards - IFRS) do International Accounting Standards Board (IASB) (MARTINS apud NIYAMA, 2005, p. 7).

De fato, as discrepâncias entre as normas locais e as internacionais podem conduzir a resultados conflitantes. Por exemplo, entre as emissoras brasileiras de American Depositary Receipts (ADRs) na New York Stock Exchange (NYSE), a CEMIG apresentou em 2002 um prejuízo de R\$12 milhões conforme as normas americanas (United States Generally Accepted Accounting Principles - US GAAP) e, conforme as normas brasileiras, um prejuízo de $R \$ 1$ bilhão (ou seja, 83 vezes maior)1. Também a CSN apresentou no mesmo ano um lucro de $R \$ 6$ milhões conforme os US GAAP, contra um prejuízo de R\$218 milhões conforme as normas brasileiras (ou seja, 30 vezes maior)2.

Desde os anos 1980, vários estudos internacionais vêm buscando identificar diferenças nos resultados apurados segundo sistemas contábeis de diversos países em comparação aos US GAAP, bem como interpretar as causas dessa diversidade à luz de fatores econômicos e culturais específicos das sociedades e países (GRAY, 1980; 1985; 1988; WEETMAN; GRAY, 1990; 1991; WEETMAN et al. 1998; dentre outros)." (SANTOS, Edilene Santana; CIA, Joanília Neide Sales \& CIA, Josilmar Cordenonssi. US GAAP x Normas Brasileiras: Mensuração do Impacto das Diferenças de Normas no Lucro Duplamente Reportado pelas Empresas Brasileiras Emissoras de ADRS na NYSE. In: Revista de Administração Mackenzie, v. 12. n. ${ }^{\circ}$, São Paulo, 2011. Disponível em <http://www.scielo.br/scielo.php?pid=S167869712011000100004\&script=sci_arttext> Acesso em 24.02.2013.)

131 "A ideia fundamental subjacente a essa iniciativa é que, caso o mercado realmente valorize as boas prática de governança corporativa, a migração para as listagens diferenciadas implicará maiores retornos e maior liquidez para os investidores e maior valorização das empresas. A maior liquidez assim conquistada refletir-se-á no desenvolvimento do mercado de capitais.” (BETTARELLO, Flávio Campestrin. Governança Corporativa - Fundamentos Jurídicos e Regulação. São Paulo: Quartier Latin, 2008, p. 118)
} 


\section{O PODER DE CONTROLE NAS SOCIEDADES POR AÇÕES}

\section{O PODER DE CONTROLE NA SOCIEDADE EMPRESÁRIA}

Segundo Robert Henry Srour ${ }^{132}$, uma organização, que é um conceito mais amplo que o conceito de sociedade empresária, consiste em uma coletividade coesa dotada de dinâmica interna, de unidade de ação e de decisão e de uma estabilidade estrutural criada pela hierarquia de posições em razão da especialização do trabalho, criada deliberadamente, organizada e planejada para o exercício de atividades especializadas na produção de bens e/ou serviços destinados ao mercado, que combina recursos, bens de produção e o trabalho de agentes sociais, visando à eficiência de suas atividades desempenhadas cooperativa e coordenadamente para a consecução de seus objetivos e metas específicos.

Aplicando o conceito de organização supra mencionado aos conceitos de atividade empresarial e de sociedade anônima constantes, respectivamente do art. 966 do Código Civil ${ }^{133}$ e dos arts. $1^{\text {o e }} 2 .^{\circ}$ da Lei n. ${ }^{\circ} 6.404 / 76^{134}$, podemos considerar a sociedade anônima como sendo uma ficção jurídica criada por meio de contrato plurilateral, dotada de estrutura hierárquica interna, organizada segundo a especialização do trabalho, que apresenta uma unidade de ação viabilizadora da exploração profissional, com finalidade lucrativa, de atividade econômica organizada para a produção de bens e serviços destinados ao mercado, bem como permite a obtenção de financiamento privado diretamente através da negociação de valores mobiliários no mercado de capitais,

\footnotetext{
${ }^{132}$ In: Poder, Cultura e Ética nas Organizações. 3. ${ }^{a}$ edição. Rio de Janeiro: Elsevier, 2012, p. 69 - 72.

133 "Art. 966. Considera-se empresário quem exerce profissionalmente atividade econômica organizada para a produção ou a circulação de bens ou de serviços." (BRASIL. Lei n. ${ }^{\circ}$ 10.406, de 10 de janeiro de 2002. Institui o Código Civil. Disponível em < http://www.planalto.gov.br/ccivil_03/leis/2002/110406.htm>. Acesso em 02.11.2014)

134 "Art. $1^{\circ}$ A companhia ou sociedade anônima terá o capital dividido em ações, e a responsabilidade dos sócios ou acionistas será limitada ao preço de emissão das ações subscritas ou adquiridas.

Art. $2^{\circ}$ Pode ser objeto da companhia qualquer empresa de fim lucrativo, não contrário à lei à ardem pública e aos bons costumes." (BRASIL. Lei n. ${ }^{\circ}$ 6.404, de $15 \mathrm{~d}$ dezembro de 1976. Dispõe sobre as sociedades por ações. Disponível em <http://www.planalto.gov.br/ccivil_03/leis/16404consol.htm>. Acesso em: 02.11.2014)
} 
pressupondo a existência de unidade de decisão através do exercício do poder empresarial pelo acionista controlador, enquanto fonte de coesão e orientação das atividades empresariais.

O acionista controlador, portanto, é o titular dos direitos de sócio em porcentagem suficiente que lhe garanta uma ascendência, um predomínio sobre a estrutura organizacional da companhia, bem como lhe permita irradiar influência e, assim, apresentar unidade de decisão para orientar as atividades empresariais de maneira organizada e coordenada.

$\mathrm{O}$ poder detido pelo acionista controlador funda-se indiretamente sobre a propriedade econômica e jurídica ${ }^{135}$ dos meios de produção e dos frutos do trabalho, consistente, respectivamente, na capacidade de apropriação do excedente gerado pelo trabalho e no direito de dispor dos meios de produção e dos frutos do trabalho ${ }^{136}$.

Ora, sabe-se que, no sistema de produção capitalista ${ }^{137}$, o qual á fundado no capital produtivo industrial, há os empreendedores que detêm os meios de produção e, no outro extremo, os trabalhadores, que, justamente por serem desprovidos dos meios de produção, estabelecem uma relação jurídica contratual com os empreendedores para a venda das respectivas forças de trabalho.

A exploração da força de trabalho, como bem ensinavam os economistas ingleses contemporâneos como Adam Smith e, ainda, como acrescentou Karl Marx por

135 "É preciso distinguir propriedade econômica e propriedade jurídica: ao passo que a primeira remete especificamente à apropriação do sobreproduto (excedentes econômicos em relação às necessidades de reposição da força de trabalho e dos demais insumos), a segunda se refere a uma relação politicamente definida - o direito de dispor dos meios de produção e dos produtos do trabalho. Geralmente, os dois tipos de propriedade coincidem, mas nem sempre." (SROUR, Robert Henry. Poder, Cultura e Ética nas Organizações. 3. ${ }^{a}$ edição. Rio de Janeiro: Elsevier, 2012, p. 86, nota . ${ }^{\circ}$ 9)

136 "Para sermos mais precisos ainda, diremos que as relações de propriedade operam como chaves de decifração da estrutura social. Ao descobrirmos quem se apropria dos excedentes gerados na produção, identificamos o proprietários econômicos e entendemos os interesses contraditórios que se confrontam." (Idem, ibidem, p. 82)

137 "No modo de produção capitalista, a relação antitética se faz entre o burguês, que é o detentor do capital, e o proletário, que nada possui e só vive na medida em que vende sua força de trabalho. (...) O sistema capitalista consiste na produção de mercadorias. Mercadoria é tudo o que é produzido não tendo em vista o valor de uso (...), mas o valor de troca, isto é, a venda do produto. Sendo a mercadoria um produto do trabalho, o seu valor é determinado pelo total de trabalho socialmente necessário para produzi-la. (...) Ou seja, a força de trabalho pode criar um valor superior. A parte do trabalho excedente não e paga ao operário, mas serve para aumentar cada vez mais o capital."(ARANHA, Maria Lúcia de Arruda \& MARTINS, Maria Helena Pires. Filosofando: Introdução à Filosofia. São Paulo: Moderna, 1991, p. 275 276) 
meio de sua doutrina, acabava gerando um excedente ${ }^{138}$, que não era atribuído aos trabalhadores, mas apropriado pelo empreendedor.

Justamente, a apropriação do excedente do trabalho e do rendimento gerado pela exploração dos meios de produção (que é a mencionada propriedade econômica) e o direito de dispor não só do sobreproduto gerado pela força de trabalho, mas também do rendimento gerado pela exploração dos meios de produção conferem legitimidade ao sistema de poder empresarial.

O acionista controlador, portanto, detém a maior participação sobre a extração do excedente do trabalho e sobre a propriedade dos meios de produção da sociedade anônima, bem como, por deter maior participação acionária, possui o direito de dispor dos meios de produção e do excedente extraído do trabalho (o que, Karl Marx, já denominava de mais-valia ${ }^{139}$ ).

Assim, embora a propriedade econômica e jurídica sejam de titularidade da sociedade empresária, enquanto decorrência da personalidade jurídica atribuída àquela pessoa jurídica, a detenção do poder de controle, pelo acionista majoritário, decorre da titularidade de direitos de acionista em porcentagem suficiente para lhe conferir participação majoritária sobre a propriedade econômica e jurídica dos meios de produção e dos frutos do trabalho.

Portanto, a existência de um sistema de poder é inerente às organizações, às sociedades empresárias e, consequentemente, às sociedades anônimas, enquanto elemento

138 “O capitalismo vê a força de trabalho como mercadoria, mas é claro que ela não é uma mercadoria qualquer. Enquanto os produtos, ao serem usados, simplesmente desgastam ou desaparecem, o uso da força de trabalho significa, ao contrário, criação de valor. Os economistas clássicos ingleses, desde Adam Smith, já haviam percebido isso, ao proclamarem o trabalho como a verdadeira fonte de riqueza das sociedades (...) Os economistas ingleses já haviam postulado que o valor das mercadorias dependia do tempo de trabalho gasto na sua produção. Marx acrescentou que este tempo de trabalho se estabelecia em relação às habilidades individuais e às condições técnicas vigentes na sociedade. Por isso, dizia que o valor de uma mercadoria era dado pelo tempo de trabalho socialmente necessário à sua produção. De um modo geral, as mercadorias resultam da colaboração de várias habilidades profissionais distintas; por isso, seu valor incorpora todos os tempos de trabalho específicos." (COSTA, Maria Cristina Castilho. Sociologia: Introdução à Ciência da Sociedade. São Paulo: Moderna, 1990, p. 76 - 77)

139 "Visualiza-se, portanto, que uma coisa é o valor da força de trabalho, isto é, o salário, e outra é o quanto esse trabalho rende a mais a capitalista. Esse valor excedente produzido pelo operário é o que Marx chama de mais-valia." (Idem, ibidem, p. 79)

"Chama-se mais-valia, portanto, ao valor q eu o operário cria além do valor de sua força de trabalho, e que é apropriado pelo capitalista.” (ARANHA, Maria Lúcia de Arruda; MARTINS, Maria Helena Pires. Filosofando: Introdução à Filosofia. São Paulo: Moderna, 1991, p. 276) 
indispensável para propiciar a existência de coesão interna dentro da sociedade anônima, ou seja, para permitir que haja uma estabilidade na estrutura organizacional da empresa, dando-lhe uma dinâmica interna que permita coordenação no exercício da atividade econômica, combinando recursos, bens e mão de obra para obter eficiência produtiva e, desse modo, gerar lucratividade, cumprindo sua finalidade social.

Tal poder é exercido legitimamente pelo acionista que detiver a maior participação acionária, individual ou conjuntamente, o que lhe permitirá não só possuir ascendência dentro da hierarquia organizacional, mas também irradiar influência dentro dos órgãos internos da sociedade anônima e, assim, possuir unidade decisória, que acaba expressando-se através do poder de controle detido pelo acionista controlador.

A propósito, Karl Marx e Friedrich Engels já reconheciam, em seus escritos, a existência do poder dentro das organizações empresariais, tanto que, no Manifesto do Partido Comunista, assim afirmaram:

"A indústria moderna transformou a pequena oficina do patriarcal mestre de corporação na grande fábrica do capitalista industrial. Massas de operários, aglomerados nas fábricas, são organizadas como soldados. Como simples soldados da indústria, os operários estão subordinados a uma perfeita hierarquia de oficiais e suboficiais. Não são somente escravos da classe burguesa e do Estado burguês; mas também, diariamente e a cada hora, escravos da máquina, do contramestre e, sobretudo, do próprio burguês individual dono da fábrica." $" 140$

O sistema de poder acima mencionado tem a capacidade de gerar a composição e a coesão dos diversos interesses internos e externos envolvidos no âmbito da sociedade anônima, além de proporcionar a existência de um sistema de controle e punição.

${ }^{140}$ MARX, Karl; ENGELS, Friedrich. Manifesto do Partido Comunista. In: Cartas Filosóficas e Outros Escritos. São Paulo: Grijalbo, 1977, p. 91. 
Dessa maneira, possibilita-se o exercício organizado das atividades empresariais com um único fim: o de obter a consecução plena e eficaz dos objetivos sociais da empresa, de modo a cumprir sua função social, segundo um conjunto de decisões imperativas, que regulam e disciplinam os interesses de todos os seus membros e, ainda, organizam as relações com os agentes externos da organização, gerando a necessária coesão e integração para o bom funcionamento da sociedade anônima, sem prejuízo do controle efetivo e da respectiva atividade repressora.

Mas antes de verificar o conceito de poder de controle no âmbito da sociedade por ações, é imprescindível verificar o conceito sociológico-filosófico de poder.

Segundo Norberto Bobbio ${ }^{141}$, amalgamando os ensinamentos de Thomas Hobbes, Jean-Jacques Russeau, John Locke e Robert Dahl sobre o fenômeno de poder na filosofia política, pode-se afirmar que o poder corresponde a uma relação estabelecida entre diversos agentes, sendo que o agente dominante detém a capacidade de utilizar meios para influenciar e, assim, produzir efeitos desejados e determinar comportamentos de terceiros, que não seriam obtidos naturalmente dentro dos parâmetros da liberdade, bem como para obter bem futuro.

Conforme Amitai Etzioni, "poder é a habilidade de um indivíduo de induzir ou influenciar outro a seguir suas diretrizes ou quaisquer outras normas por ele apoiadas $", 142$.

Para Fábio Konder Comparato, em uma concepção genérica de poder baseada nas lições de Hegel, poder seria uma "força organizadora da sociedade"143.

Assim, conjugando os ensinamentos de Norberto Bobbio, de Amitai Etzioni e de Fábio Konder Comparato aos ensinamentos de Robert Henry Srour ${ }^{144}$, podemos afirmar que o poder nada mais é que uma relação estabelecida entre diversos sujeitos, na

\footnotetext{
${ }^{141}$ In: Estado, Governo, Sociedade para Uma Teoria Geral da Política. $1^{\text {a }}$ edição. $18^{\text {a }}$ Reimpressão. Rio da Janeiro: Paz e Terra, 2012, p. 76 -.93.

142 ETZIONI, Amitai. Análise Comparativa de Organizações Complexas. Rio de Janeiro: Zahar, 1974, p. 32

${ }^{143}$ COMPARATO, Fábio Konder; SALOMÃO FILHO, Calixto. O Poder de Controle na Sociedade Anônimas. 4. ${ }^{a}$ edição. Rio de Janeiro: Forense, 2005, p. 4.

${ }^{144}$ In: Poder, Cultura e Ética nas Organizações. 3. a edição. Rio de Janeiro: Elsevier, 2012, p. 89 - 125.
} 
qual há uma relação de dominação-sujeição, isto é, o sujeito dominante exerce o mando em relação aos demais "sujeitos obedientes", articulando inúmeros interesses distintos e organizando os interesses coletivos para obter e manter uma convivência harmônica.

Com isto o sujeito dominante em uma relação de poder tem a capacidade de agregar forças suficientes para permitir-lhe deter unidade de ação e de direção coordenadamente para a consecução de um fim comum.

O exercício do poder resulta na produção de efeitos desejados pelo sujeito dominante, isto é, na obtenção de comportamentos dos "sujeitos obedientes" enquanto resultado do exercício do controle, pelo sujeito dominante, sobre as ações dos "sujeitos obedientes".

Em outras palavras, na relação social de poder, o sujeito dominante, por meio da agregação de forças, torna-se capaz de deter a unidade de decisões e de direção, além da capacidade de coação, de modo que não só toma as decisões, mas também faz com que sejam cumpridas as ordens e aplicadas as sanções em caso de descumprimento.

Justamente a unidade de decisão e de direção tem o condão de organizar os interesses coletivos diversos e coordenar as atividades para que seja atingido fim comum, garantindo uma convivência entre estes interesses diversos por meio de uma relação de dominação-sujeição.

Assim, o poder possui dois atributos: a influência e o mando.

A influência, que, geralmente, decorre da ascendência hierárquica, baseia-se em elementos de cognição para atingir a adesão e concordância dos "sujeitos obedientes" em uma relação de poder, quais sejam, a persuasão e o convencimento, podendo ser chamada, segundo Robert Henry Srour, de autoridade moral.

Por outro lado, o mando, que se funda em meios físicos e impositivos, consiste no poder de dar ordens e de fazer cumpri-las. 
Não obstante a distinção indicada, tanto a influência, quanto o mando são atributos do poder que denotam a capacidade do sujeito dominante influir nos acontecimentos e no comportamento alheio ${ }^{145}$, de modo a atingir os resultados pretendidos.

Assim, como já visto acima, é inerente às organizações e, por isso, às sociedades empresárias enquanto espécies de organizações, a existência de um sistema de poder, de modo que se pode falar na existência de um poder empresarial.

Nas palavras de Alfredo Lamy Filho e José Luiz Bulhões Pedreira, “como toda organização, a empresa apresenta estrutura hierarquizada e modalidade própria de poder social: o empresário exerce o poder empresarial, que é a capacidade de causar, determinar ou alterar a atividade da empresa - assim interna (produção de bens econômicos) como externa (participação nos mercados de serviços, produtos e bens financeiros)."146

Contudo, considerando o conceito filosófico e sociológico de poder acima indicado, ousamos ampliar o conceito de poder empresarial, pois como os próprios autores citados no parágrafo antecedente afirmaram, "a análise desse poder revela que é um conjunto de diversos poderes - jurídicos e de fato." $" 147$

Com efeito, para Norberto Bobbio, "o poder econômico é aquele que se vale da posse de certos bens, necessários ou percebidos como tais, n uma situação de escassez para induzir os que não os possuem a adotar uma certa conduta, consistente principalmente na execução de um trabalho útil. Na posse dos meios de produção reside uma enorme fonte de poder por parte daqueles que os possuem contra os que não os possuem, exatamente no sentido específico da capacidade de determinar o comportamento alheio. Em qualquer sociedade onde existem proprietários e não proprietários, o poder do proprietário deriva da possibilidade que a disposição exclusiva de um bem lhe dá de obter

\footnotetext{
${ }^{145}$ Nas palavras de Fábio Konder Comparato, sob certa perspectiva o poder contrapõe-se ao direito de fruição, pois consiste na "faculdade de produzir efeitos jurídicos pela manifestação de vontade de seu titular." (COMPARATO, Fábio Konder; SALOMÃO FILHO, Calixto. O Poder de Controle na Sociedade Anônimas. 4. ${ }^{a}$ edição. Rio de Janeiro: Forense, 2005, p. 134)

${ }^{146}$ LAMY FILHO, Alfredo; PEDREIRA, José Luiz Bulhões. A Lei das S.A. Rio de Janeiro: Renovar, 1992, p. 72.

${ }^{147}$ Idem, ibidem, p. 72.
} 
que o não proprietário (ou proprietário apenas da sua força-trabalho) trabalhe para ele e nas condições por ele estabelecidas." 148

Portanto, o poder empresarial consiste em uma relação social de dominaçãosujeição estabelecida entre o acionista, que possui a maior participação sobre a propriedade econômica sobre os frutos do trabalho e sobre a propriedade jurídica dos meios de produção por meio da titularidade de ações, e os demais agentes participantes da vida interna da empresa, relação esta que confere ao acionista majoritário a agregação organizadora de forças, de modo a conferir-lhe ascendência dentro da organização hierárquica da empresa, que, por sua vez, atribui-lhe unidade de decisão imperativa, direção e coordenação das atividades exercidas, o exercício de um sistema de controle e punição em caso de descumprimento das decisões, permitindo-lhe exercer os meios de influência dos órgãos e agentes internos, determinando o comportamento de terceiros e obtendo os efeitos desejados, com o objetivo de obter uma composição harmônica dos diversos interesses envolvidos na empresa e, assim, atingir uma maior eficiência na obtenção de lucros, de modo a cumprir a função social da empresa.

Assim como em qualquer sociedade empresária, as sociedades por ações também apresentam o poder empresarial em sua estrutura interna, que recebeu a denominação legal de poder de controle.

Da análise do conceito de empresa feita acima, decorre que o poder de controle é ínsito ao conceito de empresa, surgindo conjuntamente com a criação da sociedade empresária ${ }^{149}$ e, nas sociedades por ações, é conferido ao acionista que detiver a maior participação sobre a propriedade econômica dos frutos do trabalho e sobre a propriedade jurídica dos meios de produção, as quais conferem legitimação ao acionista detentor do poder de controle.

\footnotetext{
${ }^{148}$ BOBBIO, Norberto. Estado, Governo, Sociedade para Uma Teoria Geral da Política. $1^{\mathrm{a}}$ edição. 18 Reimpressão. Rio da Janeiro: Paz e Terra, 2012, p. 82.

149 "O poder de comando surge com a organização da atividade, não a precede, nem se transfere do empresário para a atividade; ocupando o posto de nível hierárquico mais alto na cadeia de comandos da organização, investido na posição de chefe da empresa, o empresário está legitimado para exercê-lo de forma a manter a organização, a coordenação das atividades intermediárias em função do escopo produtivo." (SZTAJN, Rachel. Teoria Jurídica da Empresa. 2. a edição. São Paulo: Atlas, 2010, p. 137)
} 
Aplicando o conceito de poder no âmbito das sociedades por ações, temos que o poder empresarial corresponde ao denominado poder de controle, consistindo na autoridade empresarial fundada na propriedade econômica e jurídica dos meios de produção, que permite ao acionista controlador a detenção da capacidade de tomar as decisões, fazer cumpri-las, determinar a direção e gestão da sociedade, influenciar o comportamento dos agentes envolvidos na sociedade por ações, com o fim último de atingir a plena execução do objeto social.

O poder de controle permite à sociedade empresária a manutenção, por meio do acionista controlador, da organização de todas as forças de forma coesa e harmônica e, consequentemente, da própria relação social de dominação-sujeição com legitimidade, ou seja, com reconhecimento deste poder-função, possibilitando que o exercício organizado da atividade econômica atinja seus fins sociais do modo mais eficiente, ao permitir à sociedade empresária uma maior lucratividade possível.

O poder de controle, enquanto relação social estabelecida dentro da estrutura interna da sociedade por ações, justamente tem o condão de conferir ao acionista majoritário a detenção dos meios de controle sobre a hierarquia administrativa, da influência sobre os órgãos internos da sociedade, do poder decisório e sancionatório e da organização do complexo de bens destinados ao exercício da empresa e, também, das próprias atividades da empresa.

Em síntese, de acordo com Fábio Konder Comparato ${ }^{150}$, o acionista controlador exerce um cargo dentro da estrutura interna da sociedade por ações, de modo

\footnotetext{
150 "Na economia da nova sociedade anônima o controlador se afirma como seu mais recente órgão, ou, se preferir a explicação funcional do mecanismo societário, como o titular de um novo cargo social. Cargo, em sua mais vasta acepção jurídica, designa um centro de competência, envolvendo uma ou mais funções. $O$ reconhecimento de um cargo, em qualquer tipo de organização, faz-se pela definição de funções próprias e necessárias. Ora, tais funções existem vinculadas à pessoa do controlador, pelo menos do acionista controlador. No vigente direito acionário brasileiro, elas podem resumir-se no poder de orientar e dirigir, em última instância, as atividades sociais; ou, como se diz no art. 116, alínea b, da Lei n. ${ }^{\circ}$ 6.404/76, no poder de 'dirigir as atividades sociais e orientar o funcionamento dos demais órgãos sociais da companhia' (com o reconhecimento implícito de que o acionista controlador é um dos órgãos da companhia). Trata-se de um feixe de funções indispensáveis ao funcionamento de qualquer entidade coletiva - como assinalamos anteriormente - e especialmente da sociedade anônima. Poderia, sem dúvida, o legislador manter essas prerrogativas funcionais diluídas no corpo acionário, tal como ocorria no passado. Preferiu, no entanto, desde a Lei n. ${ }^{\circ}$ 6.404/76, localizá-las na figura do controlador." (COMPARATO, Fábio Konder; SAlomão FILHO, Calixto. O Poder de Controle na Sociedade Anônimas. 4. ${ }^{a}$ edição. Rio de Janeiro: Forense, 2005, p. 141 - 142)
} 
que tal cargo é definido pelas funções indispensáveis que exerce dentro da organização empresarial.

Ainda, segundo Fábio Konder Comparato, no Direito Societário Brasileiro, as funções do acionista controlador podem ser resumidas no exercício do poder de orientação e direção das atividades empresariais.

Com efeito, da detenção do poder de controle decorrem inúmeras funções típicas do cargo de controlador e as quais, por sua vez, acabam definindo o cargo de acionista controlador.

Dessa maneira, ao acionista controlador é atribuída originariamente a autoridade moral, também denominada de poder ideológico por Norberto Bobbio ${ }^{151}$, segundo a qual o acionista controlador possui a capacidade de influenciar toda a estrutura interna da sociedade por ações, justamente por possuir uma ascendência hierárquica.

Esta capacidade de influenciar somente é possível quando o acionista controlador exerce efetivamente sua função de cooptação e designação dos gestores, os quais, por sua vez, exercem poderes institucionais atribuídos com fundamento na confiança e na afinidade que deve existir entre o acionista controlador e os gestores designados.

Outra função exercida pelo acionista controlador ainda que por meio de seus gestores designados, consiste no que Robert Henry Srour ${ }^{152}$ denomina de poder coercitivo, que consiste na realização dos objetivos eleitos em conformidade com o objeto da companhia, dele decorrendo diretamente a força organizativa e agregadora dos diversos interesses envolvidos no âmbito de uma sociedade por ações.

O poder coercitivo do acionista controlador pressupõe a determinação das diretrizes e a emissão de ordens aos agentes hierarquicamente subordinados, ou seja, o

151 “O poder ideológico é aquele que se vale da posse de certas formas de saber, doutrinas, conhecimentos, às vezes apenas de informações, ou de códigos de conduta, para exercer uma influência sobre o comportamento alheio e induzir os membros do grupo a realizar ou não realizar uma ação."(BOBBIO, Norberto. Estado, Governo, Sociedade para Uma Teoria Geral da Política. $1^{\mathrm{a}}$ edição. $18^{\mathrm{a}}$ Reimpressão. Rio da Janeiro: Paz e Terra, 2012, p. 82 - 83)

${ }^{152}$ In: Poder, Cultura e Ética nas Organizações. 3. a edição. Rio de Janeiro: Elsevier, 2012, p. 107. 
poder coercitivo exige o prévio planejamento de ações, a organização das atividades e a direção dos esforços coletivos ao fim específico da sociedade.

Ao lado da autoridade moral, do poder de designar e cooptar os gestores e do poder coercitivo, o acionista controlador, também, exerce o poder deliberativo, que justamente consiste na definição dos rumos, das diretrizes e da política empresarial a ser seguida pelos subordinados hierárquicos e, desse modo, a servir de orientação no desempenho de todas as atividades da sociedade por ações, denotando, portanto, a existência de uma unidade decisória imperativa.

Por fim, confere-se ao controlador o poder de julgar, ou seja, o poder de analisar e emitir juízos com a finalidade de arbitrar disputas internas, o que é feito por meio de um sistema de controle e de punições aplicadas em caso de não observância da imperatividade das decisões tomadas no âmbito da sociedade.

Portanto, constata-se que a noção de poder de controle é ínsita ao conceito de sociedade empresária, na qual estão presentes, segundos ensinamentos de Norberto Bobbio $^{153}$, os três poderes sociais, quais sejam o poder econômico, que é o poder de obter o trabalho de pessoas não detentoras da propriedade econômica e jurídica dos meios de produção, o poder ideológico enquanto capacidade de influenciar o comportamento alheio e induzir a prática ou não de certas atividades e o poder coativo como sendo aquele que visa a impedir a insubordinação dos demais agentes hierarquicamente subordinados ao acionista controlador.

O poder detido pelo acionista controlador funda-se na propriedade econômica e jurídica dos meios de produção ${ }^{154}$ e é indispensável para a destinação de um complexo de bens, que compõe os fatores de produção que, por sua vez, são organizados para o exercício profissional da atividade econômica com a finalidade de obter lucros.

\footnotetext{
${ }^{153}$ In: Estado, Governo, Sociedade para Uma Teoria Geral da Política. $1^{\mathrm{a}}$ edição. $18^{\mathrm{a}}$ Reimpressão. Rio da Janeiro: Paz e Terra, 2012, p. 82 - 84.

154 "No tocante às empresas capitalistas é importante frisar que o poder supremo é detido pelos proprietários (acionistas ou cotistas), porque a propriedade é do tipo pleno, individual e alodial. Os proprietários dispõem de seus bens e de seu negócio da forma que bem lhes aprouver, a não ser que sejam judicialmente interditados. A propriedade é fonte de benefícios econômicos, mas é também a base legal do poder nas empresas." (SROUR, Robert Henry. Poder, Cultura e Ética nas Organizações. 3. a edição. Rio de Janeiro: Elsevier, 2012, p. 108 - 109)
} 
Assim, do conceito de sociedade por ações (e de sociedade empresária de um modo geral), constata-se a necessidade de haver uma figura, que oriente o exercício profissional e organizado da atividade econômica, isto é, as sociedades por ações, assim como as demais sociedades empresárias, requer a existência de um sistema de poder para que seja mantida a coesão interna, a estabilidade da estrutura organizacional e a coordenação da atividade econômica, combinando os recursos, os bens de produção e a mão de obra com eficiência produtiva, de forma a obter lucratividade e a cumprir sua função social.

Por esta razão, o art. 116 da Lei n. ${ }^{\circ} 6.404 / 76^{155}$ reconhece expressamente a existência da figura do acionista controlador, ou seja, do acionista detentor do poder de controle, que dirige as atividades da sociedade e orienta o funcionamento de seus órgãos internos, sempre com a finalidade de conduzir a sociedade para a realização do seu objeto social e ao cumprimento da sua função social, seja perante os demais acionistas e os empregados da sociedade, seja perante a comunidade na qual a sociedade atua (vide art. 116, parágrafo único, da Lei n. ${ }^{\circ} 6.404 / 76^{156}$ ).

\footnotetext{
155 “Art. 116. Entende-se por acionista controlador a pessoa, natural ou jurídica, ou o grupo de pessoas vinculadas por acordo de voto, ou sob controle comum, que:

a) é titular de direitos de sócio que lhe assegurem, de modo permanente, a maioria dos votos nas deliberações da assembleia geral e o poder de eleger a maioria dos administradores da companhia; $e$

b) usa efetivamente seu poder para dirigir as atividades sociais e orientar o funcionamento dos órgãos da companhia." (BRASIL. Lei n. ${ }^{\circ} 10.406$, de 10 de janeiro de 2002. Institui o Código Civil. Disponível em < http://www.planalto.gov.br/ccivil_03/leis/2002/110406.htm>. Acesso em 02.11.2014)

156 "Parágrafo único. $O$ acionista controlador deve usar o poder com o fim de fazer a companhia realizar o seu objeto e cumprir sua função social, e tem deveres e responsabilidades para com os demais acionistas da empresa, os que nela trabalham e para com a comunidade em que atua, cujos direitos e interesses deve lealmente respeitar e atender." (Idem, ibidem)
} 


\section{O PODER DE CONTROLE NA LEI N. ${ }^{\circ} 6.404 / 76$}

Como visto anteriormente, somente a partir da Lei n. ${ }^{\circ}$ 6.404/76, o ordenamento jurídico brasileiro passou a prever de maneira sistematizada a figura do acionista controlador, atribuindo-lhe, inclusive, um regime jurídico específico quanto aos deveres, responsabilidades e funções.

Observe-se que, como apontou Fábio Konder Comparato ${ }^{157}$, embora não estivesse previsto expressamente o regime jurídico do poder de controle e/ou do acionista controlador, em todas as etapas da evolução histórico-legislativa das companhias, estava presente o poder de controle detido pelo acionista controlador, ainda que implicitamente.

O Decreto-lei n. ${ }^{\circ} 2.627 / 40$ não fazia nenhuma referência expressa ao acionista controlador, mas apenas em alguns dispositivos esparsos mencionava a figura do acionista fundador, seja ao permitir o uso de seu nome para formar a denominação da companhia (art. $3^{\circ}, \S 1 .^{\circ}$, do Decreto-lei n. ${ }^{\circ} 2.627 / 40^{158}$ ), seja ao autorizar que o prospecto de constituição previsse as vantagens particulares que seriam atribuídas ao fundador (art. 40, inciso IV, alínea ' $\mathrm{f}$ ', do Decreto-lei $\mathrm{n}^{\circ}$. 2.627/40 ${ }^{159}$ ) ou, ainda, ao prever a responsabilidade solidária por descumprimento culposo ou doloso de preceitos legais referentes à constituição ou por atos ou operações anteriores à constituição (art. 49 do Decreto-lei n. ${ }^{\circ} 2.627 / 40^{160}$ ).

\footnotetext{
157 "Ora, é interessante observar que esse elemento do poder, não dissolvido no anonimato ou na ficção numérica, esteve sempre presente em todas as construções jurídicas da sociedade por ações, nos primeiros tempos." (COMPARATO, Fábio Konder. Poder de Controle na Sociedade Anônima. In Revista de Direito Mercantil. São Paulo: Revista dos Tribunais, Ano XII, n. ${ }^{\circ}$ 9, 1973, p. 68)

158 "Art. 3" (...)

$\S 1^{\circ} O$ nome de fundador, acionista, ou pessoa que por qualquer outro modo tenha concorrido para o êxito da empresa, poderá figurar na denominação." (BRASIL. Decreto-lei n. ${ }^{\circ}$ 2.627, de 26 de setembro de 1940. Dispõe sobre as sociedades por ações. Disponível em < http://www.planalto.gov.br/ccivil_03/decretolei/del2627.htm>. Acesso em 02.11.2014)

159 “Art. 40. Na constituição da sociedade por subscrição pública, observar-se-ão os seguintes preceitos: (...)

$V$, o prospecto mencionará claramente:

(...)

f) as vantagens particulares, a que terão direito os fundadores ou terceiros, e o artigo do projeto dos estatutos que as regula;" (Idem, ibidem)

160 "Art. 49. Os fundadores, no caso de culpa ou dolo, respondem solidariamente pelo prejuízos resultantes da inobservância dos preceitos legais relativos à constituição da sociedade, bem como pelos que se
} 
Logo, na legislação revogada, não se tinha uma previsão da figura do acionista controlador, tampouco da existência de um regime jurídico próprio de direitos, deveres e responsabilidades atribuídos ao controlador. Talvez, esta ausência de previsão possa ser explicada pelo fato de vigorar o princípio da igualdade dos acionistas, isto é, não havia, no regime jurídico do Decreto-lei n. ${ }^{\circ}$ 2.627/40 distinção entre acionistas minoritários e acionista controlador, sendo aquele princípio-base das companhias naquela época.

Acrescente-se, também, que o mencionado diploma legal também fazia menção à necessidade de maioria absoluta de votos para a tomada de decisões na Assembleia Geral, sem fazer qualquer referência à qualidade de acionista controlador (art. 94 do Decreto-lei n. $\left.{ }^{\circ} 2.627 / 40^{161}\right)$.

Assim, segundo o regime jurídico então vigente das sociedades por ações, o controle era aleatório e se expressava através do voto prevalecente nas deliberações da Assembleia Geral, de forma que os acionistas titulares de ações ordinárias poderiam formar o voto prevalecente e aleatoriamente, visto que a estrutura legal das companhias permitia que todo acionista com direito de votar poderia compor a formação do voto prevalecente e, por isso, eleger os administradores a quem era atribuída a gestão da companhia.

Portanto, constata-se que a legislação reguladora das sociedades por ações anterior à Lei n. ${ }^{\circ}$ 6.404/76 não trazia uma sistematização a respeito do acionista controlador ou do poder de controle ${ }^{162}$, o que, inclusive, poderia dificultar a exata compreensão de como a estrutura organizacional da sociedade por ações funcionava.

Decorria do sistema legal, então em vigor, que aquele que detivesse a maioria dos votos nas deliberações tomadas em assembleia geral poderia ser considerado como sendo o acionista ou o grupo de acionistas prevalecente, não necessariamente o

originarem de atos ou operações anteriores." (BRASIL. Decreto-lei n. ${ }^{\circ}$ 2.627, de 26 de setembro de 1940. Dispõe sobre as sociedades por ações. Disponível em < http://www.planalto.gov.br/ccivil_03/decretolei/del2627.htm>. Acesso em 02.11.2014)

161 “Art. 94. As deliberações da assembléia geral ressalvadas as exceções previstas na lei, são tomadas por maioria absoluta de votos, não se computando os votos em branco." (Idem, ibidem)

162 "Volta-se, assim, à situação que existia sob a égide da Lei n. ${ }^{\circ} 2.627$, de 1940 (sic), marcada pelo caráter aleatório do comando social, pois completamente ausente, à época, o instituto do controle, trazido pela Lei n. ${ }^{\circ}$ 6.404, de 1976." (CARVALHOSA, Modesto. Comentários à Lei das Sociedades Anônimas. Vol. 2. ${ }^{\circ}$. 5. ${ }^{a}$ edição. São Paulo: Saraiva, 2011, p. 582) 
acionista controlador, pois, na sistemática do Decreto-lei n. $^{\circ} 2.627 / 40$, mesmo sendo a Assembleia Geral um órgão primário da companhia, ela não era a própria companhia.

Conforme afirma Fábio Konder Comparato, "quando se fala em controle no sentido de dominação, na sociedade anônima, alude-se a um poder que transcende as prerrogativas legais da própria assembleia ${ }^{, 163}$.

Isto porque a decisão assemblear tem o condão de legitimar o exercício do controle da sociedade anônima ${ }^{164}$, não se restringindo ao exercício do direito de voto, justamente por ser um poder maior que o exercido dentro da assembleia geral e que implica na dominação da companhia.

Segundo a interpretação dada à menção à sociedade controlada e à sociedade coligada no art. $135, \S 2 .^{\circ}$, do Decreto-lei n. ${ }^{\circ} 2.627 / 40$, em conjugação aos dispositivos já indicados do mesmo Decreto-lei, especialmente o art. 94, entendia-se que o poder de controle da companhia era o majoritário, visto que a assembleia geral, embora recepcionasse a manifestação de vontade de todos os acionistas, ela somente reproduziria a vontade da corrente de acionistas mais fortes, isto é, a que detivesse a maioria absoluta de votos e que, portanto, teria a capacidade de eleger os administradores, constituindo, a diretoria, o órgão de comando das sociedades por ações.

Assim, a sociedade por ações, nos termos da regulação do Decreto-lei n. ${ }^{\circ}$ 2.627/40, deveria estar dotada de organização suficiente para expressar a manifestação de vontade coletiva a prevalecer em Assembleia Geral, que seria, então, a vontade do grupo mais forte e, portanto, prevalecente de acordo com o princípio majoritário, in verbis:

“Em todo o caso que nós venhamos a passar em revista, o interesse é aquele de um grupo que se organiza espontaneamente ou quase espontaneamente (1), em vista de produzir a vontade necessária ao exercício do direito;

${ }^{163}$ COMPARATO, Fábio Konder. O Poder de Controle na Sociedade Anônima.1. a edição. São Paulo: Revista dos Tribunais, 1976, p. 16.

164 “Quem toma, de fato, as decisões em assembleia? O controle manifesta-se através dos poderes decisórios da assembléia de acionistas, como necessária legitimação do seu exercício. Mas essa legitimação é meramente formal ou procedimental." (COMPARATO, Fábio Konder. O Poder de Controle na Sociedade Anônima.1. ${ }^{\text {a }}$ edição. São Paulo: Revista dos Tribunais, 1976, p. 23) 
(...)

É necessário que o grupo, que aspira à personalidade jurídica, tenha uma organização capaz de manifestar uma vontade coletiva que a representará nas relações jurídicas. Essa vontade não será sempre, metafisicamente, senão a vontade de indivíduos isolados, mas, socialmente, isto é, praticamente, ela deverá ou poderá ser encarada como formadora da vontade do grupo."165 (tradução livre)

Uma vez organizada a vontade social prevalecente, caberá à Assembleia Geral legitimá-la para impô-la aos demais órgãos sociais, proporcionando o funcionamento da companhia.

Neste sentido, são os comentários de Trajano de Miranda Valverde:

"Vige, nas assembleias gerais das sociedades por ações, o princípio majoritário, princípio que domina nas organizações colegiais ou nas reuniões deliberativas, porque seria impraticável a exigência da unanimidade, da concordância, enfim, de todos os membros, para que em uma corporação se pudesse tomar deliberação de interesse geral. Raramente, com efeito, em uma reunião ou assembleia deliberativa haverá uniformidade no modo de encarar o assunto submetido à apreciação e ao julgamento dos seus componentes. O direito havia de procurar uma fórmula que solucionasse as divergências e garantisse a continuidade da pessoa jurídica. Foi encontrá-la no princípio

\footnotetext{
165 "Dans tous les cas que nous venons de passer en revue, l'intérêt est celui d'un grupe qui s'organise, spontanément ou quasi-spontabément (1), en vie de produire la volonté nécessaire à l'exercise du droit ; (...) Il faut que le groupe qui aspire à la personnalité ait une organisation capable de dégager une volonté collective qui le représentera dans les rapports juridiques. Cette volonté ne sera toujours métaphysiquement que la volonté d'individus isolés, mais socialement, c'est-à-dire pratiquement, elle devra ou pourra être regardée comme formant la volonté du groupe." (MICHOUD, Léon. La Théorie de la Personnalité Morale et Son Application au Droit Français. V. 1. 2. ${ }^{a}$ edição. Paris: Librarie Générale de Droit \& de Jurisprudence, 1924, p. 115 e p. 116-117)
} 
majoritário, já disciplinado nas instituições de direito público dos romanos. $" 166$

Adiante, Trajano de Miranda Valverde indica forma de apuração da vontade prevalecente no âmbito das sociedades por ações:

"A assembleia geral dos acionistas, como órgão da pessoa jurídica, recebe a energia volitiva dos membros que a compõem, mas só filtra a corrente mais forte, manifestada pela voz da maioria, corrente que movimentará o corpo social, através de seu órgão de direção. A diretoria compete, normalmente, executar as deliberações da assembleia geral, ou, pelo menos, providenciar para que as deliberações dela cheguem ao conhecimento de todos os interessados."167

Dessa forma, apurada a vontade prevalecente, era imprescindível a sincronização desta vontade prevalecente e o funcionamento dos demais órgãos sociais, pois "a assembleia geral, embora seja o órgão supremo de direção e administração da sociedade, o que maiores poderes enfeixa, não exclui ou anula a ação dos demais diretoria, conselho fiscal e outros criados pelos estatutos - nem os absorve ou tolhe. Há atos que a assembleia geral não pode executar por serem da alçada exclusiva da diretoria ou do conselho fiscal."168

A sincronização dos interesses prevalecentes e o funcionamento dos órgãos sociais, salvo melhor juízo, caberia ao acionista ou grupo de acionistas detentor do poder de controle, permitindo que a companhia executasse seu objeto social harmonicamente, in verbis:

"É imprescindivel a harmonia entre eles, para que a sociedade possa existir perfeitamente e desenvolver-se. A consecução dos objetivos sociais só se poderá obter com o funcionamento sincrônico desses

\footnotetext{
166 VALVERDE, Trajano de Miranda. Sociedades por Ações. Vol. II. 2. a edição. Rio de Janeiro: Revista Forense, 1953, p. $109-110$.

${ }^{167}$ Idem, ibidem, p. $111-112$.

${ }^{168}$ PONTES, Aloysio Lopes. Sociedades Anônimas. Vol. II. 4. ${ }^{\text {a }}$ edição. Rio de Janeiro: Revista Forense, 1957, p. 60.
} 
órgãos, cada qual desincumbindo-se de suas atribuições, auxiliando-se mutuamente, mas sem interferir na esfera de ação dos demais." 169

Pode-se constatar que, na legislação revogada, embora não tivesse uma sistematização acerca do poder de controle, este decorria implicitamente do sistema jurídico regulador das companhias, o que, inclusive, acabou encontrando ressonância na legislação posterior que fora promulgada com o intuito de estimular o desenvolvimento do mercado de capitais.

Com efeito, a Lei n. ${ }^{\circ}$ 4.131, de 03.09.1962, que disciplinou a aplicação do capital estrangeiro e a remessa de valores ao exterior, em seu art. $3 .^{\circ}$, parágrafo único ${ }^{170}$, mencionou o poder de controle detido por pessoas físicas ou jurídicas, com residência ou sede no exterior, que fossem titulares da "maioria de ações", sem fazer referência ao direito de voto das mesmas.

Posteriormente, a Lei n. ${ }^{\circ}$ 4.728/65, que disciplinou o mercado de capitais e estabeleceu medidas estimuladoras de seu desenvolvimento, em cinco dispositivos fez expressa referência ao poder de controle das companhias, dando continuidade à referência expressa ao controle na legislação brasileira, embora ainda sem qualquer sistematização.

169 PONTES, Aloysio Lopes. Sociedades Anônimas. Vol. II. 4. ${ }^{\text {a }}$ edição. Rio de Janeiro: Revista Forense, 1957 , p. 60.

170 “Art. $3^{\circ}$ Fica instituído, na Superintendência da Moeda e do Crédito, um serviço especial de registro de capitais estrangeiros, qualquer que seja sua forma de ingresso no País, bem como de operações financeiras com o exterior, no qual serão registrados:

a) os capitais estrangeiros que ingressarem no País sob a forma de investimento direto ou de empréstimo, quer em moeda, quer em bens;

b) as remessas feitas para o exterior com o retorno de capitais ou como rendimentos desses capitais, lucros, dividendos, juros, amortizações, bem como as de "royalties", ou por qualquer outro título que implique transferência de rendimentos para fora do País;

c) os reinvestimentos de lucros dos capitais estrangeiros; vigor.

d) as alterações do valor monetário do capital das empresas procedidas de acordo com a legislação em

Parágrafo único. O registro dos reinvestimentos a que se refere a letra "c" será devido, ainda que se trate de pessoa jurídica com sede no Brasil mas filiada a empresas estrangeiras ou controlada por maioria de acões pertencentes a pessoas físicas ou jurídicas com residência ou sede no estrangeiro." (BRASIL. Lei n. ${ }^{\circ}$ 4.131, de 03 de setembro de 1962. Disciplina a aplicação do capital estrangeiro e as remessas de valores para o exterior e dá outras providências. Disponível em < http://www.planalto.gov.br/ccivil_03/leis/L4131.htm>. Acesso e 02.11.2014) 
No art. 16, §1. ${ }^{\circ}$, alínea 'c' ${ }^{171}$, a Lei n. ${ }^{\circ} 4.728 / 65$ reconhecia que o poder de controle das sociedades por ações poderia ser detido tanto por pessoas físicas, quanto por pessoas jurídicas.

Mais adiante, a Lei n. ${ }^{\circ}$ 4.728/65 indicou o que considerava como sendo acionista controlador. Este seria aquele que detivesse a maioria do capital com direito a

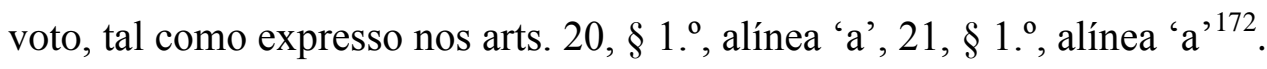

171 “Art. 16. As emissões de títulos ou valôres mobiliários somente poderão ser feitas nos mercados financeiro e de capitais através do sistema de distribuição previsto no art. $5^{\circ}$.

$\S 1^{\circ}$ Para os efeitos dêste artigo considera-se emissão a oferta ou negociação de títulos ou valôres mobiliários:

(...)

c) pela pessoa natural ou jurídica que mantém o contrôle da sociedade emissôra dos títulos ou valôres mobiliários oferecidos ou negociados." (BRASIL. Lei n. ${ }^{\circ} 4.728$, de 14 de julho de 1965. Disciplina o mercado de capitais e estabelece medidas para o seu desenvolvimento. Disponível em < http://www.planalto.gov.br/ccivil_03/leis/14728.htm>. Acesso em 02.11.2014)

172 “Art. 20. Compete ao Conselho Monetário Nacional expedir normas gerais sôbre o registro referido no inciso II do artigo anterior, e relativas a:

I - informações e documentos a serem apresentados para obtenção do registro inicial;

II - informações e documentos a serem apresentados periodicamente para a manutenção do registro;

III - casos em que o Banco Central poderá recusar, suspender ou cancelar o registro.

$\S 1^{\circ}$ Caberá ainda ao Conselho Monetário Nacional expedir normas a serem observadas pelas pessoas jurídicas referidas neste artigo, e relativas a:

a) natureza, detalhe e periodicidade da publicação de informações sôbre a situação econômica $e$ financeira da pessoa jurídica, suas operações, administração e acionistas que controlam a maioria do seu capital votante; ; (Idem, ibidem)

“Art. 21. Nenhuma emissão de títulos ou valôres mobiliários poderá ser lançada, oferecida públicamente, ou ter iniciada a sua distribuição no mercado, sem estar registrada no Banco Central.

$\$ 1^{\circ}$ Caberá ao Conselho Monetário Nacional estabelecer normas gerais relativas às informações que deverão ser prestadas no pedido de registro previsto neste artigo em matéria de:

a) pessoa jurídica, emitente ou coobrigada, sua situação econômica e financeira, administração $e$ acionistas que controlam a maioria de seu capital votante;" (Idem, ibidem)

“Art. 22. (...) 
Já, no art. 22, § 2. ${ }^{\circ}$, a lei reguladora do mercado de capitais acrescentou outros caracteres do acionista controlador, isto é, considerou tal como os dispositivos anteriormente mencionados, que o controle seria atribuído ao acionista titular da maioria do capital com direito a voto, seja direta, seja indiretamente, podendo, ainda, o controlador ser pessoa natural ou jurídica nacional ou estrangeira.

Por fim, a mesma Lei n. ${ }^{\circ}$ 4.728/65, em um processo de justaposição, finalizou a caracterização do acionista controlador ao tratar do controle estatal nas sociedades de economia mista.

Com efeito, no art. $60^{173}$, indicou que a União, para manter o poder de controle das sociedades de economia mista, deveria manter em seu poder $51 \%$ (cinquenta e um por cento) das ações com direito a voto.

Em 10.06.1975, o então Presidente Ernesto Geisel, por meio da mensagem presidencial n. ${ }^{\circ} 160$, enviou ao Congresso Nacional o Projeto de Lei n. 634 de 1975, que instituiria o novo Código Civil Brasileiro.

O anteprojeto do novo Código Civil, em seu art. 1.132, inciso $\mathrm{I}^{174}$, definia sociedade controlada como sendo aquela, cujas ações (ou quotas sociais) representativas de mais de $50 \%$ (cinquenta por cento) do capital social votante fossem de titularidade de outra sociedade.

$\S 2^{\circ}$ Considera-se emprêsa controlada por pessoas residentes ou domiciliadas no exterior, quando estas detenham direta ou indiretamente a maioria do capital com direito a voto." BRASIL. Lei n. ${ }^{\circ} 4.728$, de 14 de julho de 1965. Disciplina o mercado de capitais e estabelece medidas para o seu desenvolvimento. Disponível em < http://www.planalto.gov.br/ccivil_03/leis/14728.htm>. Acesso em 02.11.2014

173 “Art. 60. O Poder Executivo poderá promover a alienação de ações de propriedade da União, representativas do capital de sociedades de economia mista e de suas subsidiárias, mantendo 51\% (cinqüenta e um por cento), no mínimo, das acões das emprêsas nas quais (vetado) deva assegurar o contrôle estatal." (Idem, ibidem)

174 "Art. 1.132. É controlada:

I - A sociedade, de cujo capital outra sociedade possua mais de cinqüenta por cento do capital com direito de voto." 
Por outro lado, no art. $1.133^{175}$, definia a sociedade como filiada, quando outra sociedade detivesse de $10 \%$ (dez por cento) a $50 \%$ (cinquenta por cento) do capital com direito a voto.

Ainda, o referido anteprojeto considerava mera participação a titularidade de ações (ou quotas sociais) com direito a voto, que representassem menos de $10 \%$ (dez por cento) do capital social votante, tal como previa o art. $1.134^{176}$.

Desse modo, pode-se perceber que antes da promulgação da Lei n. ${ }^{\circ}$ 6.404/76, amalgamando a legislação vigente, incluindo o anteprojeto do novo Código Civil, o acionista controlador poderia ser considerado como sendo a pessoa natural ou jurídica, nacional ou estrangeira, que, direta ou indiretamente, detivesse mais de 50\% (cinquenta por cento) do capital social votante, mesmo porque, na época em questão, o poder de controle minoritário era uma realidade inexistente no Brasil.

Não obstante ser possível extrair os caracteres principais da figura do acionista controlador e do poder de controle de diversos dispositivos legais existentes à época, nota-se haver uma distinção entre a sistemática adotada pelo Decreto-lei n. ${ }^{\circ}$ 2.627/40 e a Lei n. ${ }^{\circ}$ 6.404/76, conforme indica Modesto Carvalhosa:

"É totalmente diverso o conceito de acionista com voto prevalecente, da prática societária anterior, e o de acionista controlador, consagrado no diploma vigente. Isso porque o voto prevalecente é sempre aleatório, podendo alterar-se a cada assembleia, inclusive, pela livre circulação das ações ao portador, não havendo, em princípio, identificação alguma desses acionistas. Daí excluir-se qualquer responsabilidade dos acionistas a época.

Em consequência, a responsabilidade pelo comando da companhia, como referido era diretamente da diretoria. Somente os diretores a

\footnotetext{
175 "Art. 1.133. Diz-se filiada a sociedade de cujo capital outra sociedade possua de dez a cinquenta por cento do capital, com direito de voto."

176 “Art. 1.134. É de simples participação a sociedade de cujo capital outra sociedade possua menos de dez por cento do capital com direito de voto."
} 
tinham, consoante dispunham os arts, 116 a 123 do Decreto-lei $n^{\circ} 2.627$, de 1940."177

Com efeito, o regime jurídico instituído pela Lei $n .^{\circ}$ 6.404/76 difere do regime adotado pelo Decreto-lei n. ${ }^{\circ} 2.627 / 40$.

Inicialmente, a nova lei deixou de adotar o princípio da igualdade entre os acionistas ao prever a existência do acionista controlador e dos acionistas minoritários, pressupondo, portanto, haver desigualdade entre os acionistas, tanto que atribui expressamente ao acionista controlador uma gama de funções, deveres e responsabilidades específicos e distintos dos atribuídos aos administradores, o que não havia na legislação revogada.

Aliás, na legislação revogada, havia uma certa confusão entre a propriedade de ações com direito a voto e administração, sendo a diretoria o órgão de comando da companhia ${ }^{178}$, justamente porque os acionistas com voto prevalecente auto-elegiam-se para o exercício do cargo de diretor, havendo cumulação (e até certo ponto, confusão) das funções de comando e de gestão, conforme decorre dos arts. 116, 119 e 121 do Decreto-lei n. $2.627 / 40^{179}$.

177 CARVAlhOSA, Modesto. Comentários à Lei das Sociedades Anônimas. Vol. 2 2. ${ }^{\circ}$ 5. ${ }^{\mathrm{a}}$ edição. São Paulo: Saraiva, 2011, p. 604 - 605.

178 "De fato, no antigo regime societário de 1940, os próprios acionistas com maior número de açôes votantes ao portador é que se autoelegiam para a diretoria. Havia, assim, na prática societária, uma confusão entre propriedade de ações votantes e comando da sociedade. Era a época dos capitães de indústria e dos grupos acionários familiares, que dirigiam, eles mesmos, a companhia (...) A diretoria, em consequência, era o órgão de comando da companhia no regime do diploma de 1940. A legitimidade desse governo dos diretores originava-se do predomínio aleatório do maior número de ações votantes em cada eleição pela assembleia geral. Dava-se aos votos aleatoriamente majoritários a competência para formar a diretoria, que exercia, efetivamente, o comando social. Os diretores eram legalmente responsáveis pela condução da companhia. Somente os diretores tinham essa responsabilidade (arts. 116 a 123 do Dec.-lei $n{ }^{\circ}$ 2.627, de 1940)." (CARVALHOSA, Modesto. Comentários à Lei das Sociedades Anônimas. Vol. 2. ${ }^{\circ}$. 5. edição. São Paulo: Saraiva, 2011, p. 563)

179 "Art. 116. A sociedade anônima ou companhia será administrada por um ou mais diretores, acionistas ou não, residentes no país, escolhidos pela assembléia geral, que poderá destituí-los a todo tempo."

"Art. 119. Os diretores não poderão praticar atos de liberalidade à custa da sociedade. Não lhes será, igualmente, lícito hipotecar, empenhar ou alienar bens sociais, sem expressa autorização dos estatutos ou da assembléia geral, salvo se esses atos ou operações constituírem objeto da sociedade."

"Art. 121. Os diretores não são pessoalmente responsáveis pelas obrigações que contraírem em nome da sociedade e em virtude de ato regular de gestão." (BRASIL. Decreto-lei n. ${ }^{\circ} 2.627$, de 26 de setembro de 1940. Dispõe sobre as sociedades por ações. Disponível em < http://www.planalto.gov.br/ccivil_03/decretolei/del2627.htm>. Acesso em 02.11.2014) 
Já na Lei n. ${ }^{\circ}$ 6.404/76, há uma precisa definição da estrutura organizacional da companhia, de modo que cada um de seus órgãos, inclusive, o controlador, possuem delimitação de competência, funções, deveres e responsabilidades próprios, cabendo ao controlador a ascendência hierárquica sobre os órgãos internos, havendo, portanto, uma clara distinção entre o poder de controle e a gestão da companhia.

Ademais, deve-se ressaltar que, no regime jurídico do Decreto-lei n. ${ }^{\circ}$ 2.627/40, a Assembleia Geral não era considerada um órgão de grande relevância ${ }^{180}$, tampouco um órgão de expressão máxima do exercício do poder de controle, tanto que o Código Comercial Brasileiro de 1850 sequer a mencionava, o que somente ocorreu com a promulgação do Decreto n. ${ }^{\circ} 434$ de 04.07.1891, o qual trazia um capítulo específico acerca da Assembleia Geral, qual seja o Capítulo VI, arts. 128 a 147.

Em contrapartida, a Lei n. ${ }^{\circ}$ 6.404/76 trouxe disposições expressas e reguladoras da Assembleia Geral, dedicando-lhe os arts. 121 a 137, constantes do Capítulo XI, sem prejuízo de considerá-la como sendo um meio de forte expressão do poder de controle, tanto que associa a detenção do poder de controle também à detenção da maioria dos votos nas deliberações assembleares.

Por fim, o novo regime jurídico inaugurado em 1976 permite o exercício do poder de controle por acionista controlador aritmeticamente totalitário, majoritário ou minoritário, não exigindo a detenção de certa porcentagem para ficar caracterizada a detenção do poder de controle, tal como ocorria antes da promulgação da Lei n. ${ }^{\circ}$ 6.404/76, que, frise-se, exigia a detenção de $50 \%$ (cinquenta por cento) mais uma ação com direito a voto para considerar o seu titular como sendo o acionista controlador, sociedade controladora ou de comando de grupo ${ }^{181}$, conceitos estes considerados nos termos das

\footnotetext{
180 “Aliás, a assembleia geral de acionistas, nos primeiros séculos de existência das anônimas, nunca foi considerada um órgão importante, e muito menos a expressão do poder supremo da sociedade. O CCom brasileiro de 1850, seguindo o modelo francês, nem cogitou da sua existência. O Decreto n. 434, de 18i91, veio a regular seu funcionamento, para dispor que os estatutos deveriam determinar o número de ações que cada acionista deveria ter no conclave, e o número de votos que competiria a cada um, na razão do número de ações que possuísse."(COMPARATO, Fábio Konder. Poder de Controle na Sociedade Anônima. In Revista de Direito Mercantil. São Paulo: Revista dos Tribunais, Ano XII, n. ${ }^{\circ}$ 9, 1973, p. 68.)

${ }^{181} \mathrm{O}$ regime jurídico do Decreto-lei n. ${ }^{\circ} 2.627 / 40$ não indicava haver um comando unificado do grupo de sociedades, mas sim mera organização individual e autônoma das sociedades pertencentes ao grupo para que os respectivos objetos sociais fossem atingidos. Veja, a propósito, CARVALHOSA, Modesto. Comentários

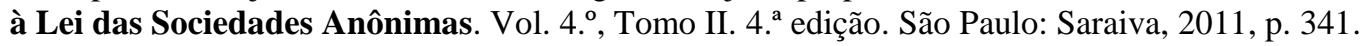


definições constantes, respectivamente, dos arts. 116 , caput, $243, \S 2 .^{\circ}$ e $265, \S 1 .^{\text {o182 }}$, da Lei $\mathrm{n}^{\circ}$ 6.404/76 (não em termos de porcentagem mínima necessária para sua caracterização).

Para que seja caracterizado um acionista como acionista controlador, basta que reúna os caracteres elencados pela legislação vigente e que, nas sociedades por ações, encontram-se basicamente indicados nos arts. 116 e 243, § 2. ${ }^{\circ}$, da Lei n. $.^{\circ} 6.404 / 76$, cuja reunião, além de atribuir ao acionista o caráter-encargo-função de controlador, atribui-lhe deveres e responsabilidades determinadas e delineadas nos arts. 117 e 246 da Lei n. ${ }^{\circ}$ 6.404/76.

Ao analisar-se a estrutura legal construída pela Lei n. ${ }^{\circ}$ 6.404/76, constata-se que o modelo previsto na vigente legislação visa primordialmente, mas não exclusivamente, à grande empresa e ao oferecimento à empresa de uma maior quantidade de meios para que se capitalize, quais sejam, os valores mobiliários, conforme constou da Exposição de Motivos n. ${ }^{\circ}$ 196, de 24.06.1976, do Ministério da Fazenda:

“4. O Projeto visa basicamente a criar a estrutura jurídica necessária ao fortalecimento do mercado de capitais de risco no País, imprescindível à sobrevivência da empresa privada na fase atual da economia brasileira.

182 “Art. 116. Entende-se por acionista controlador a pessoa, natural ou jurídica, ou o grupo de pessoas vinculadas por acordo de voto, ou sob controle comum, que:

a) é titular de direitos de sócio que lhe assegurem, de modo permanente, a maioria dos votos nas deliberações da assembleia geral e o poder de eleger a maioria dos administradores da companhia; $e$

b) usa efetivamente seu poder para dirigir as atividades sociais e orientar o funcionamento dos órgãos da companhia."

“Art. 243. O relatório anual da administração deve relacionar os investimentos da companhia em sociedades coligadas e controladas e mencionar as modificações ocorridas durante o exercício.

(...)

$\$ 2^{\circ}$ Considera-se controlada a sociedade na qual a controladora, diretamente ou através de outras controladas, é titular de direitos de sócio que lhe assegurem, de modo permanente, preponderância nas deliberações sociais e o poder de eleger a maioria dos administradores."

"Art. 265. A sociedade controladora e suas controladas podem constituir, nos termos deste Capítulo, grupo de sociedades, mediante convenção pela qual se obriguem a combinar recursos ou esforços para a realização dos respectivos objetos, ou a participar de atividades ou empreendimentos comuns.

$\S 1^{\circ}$ A sociedade controladora, ou de comando do grupo, deve ser brasileira, e exercer, direta ou indiretamente, e de modo permanente, o controle das sociedades filiadas, como titular de direitos de sócio ou acionista, ou mediante acordo com outros sócios ou acionistas." (BRASIL. Lei n. ${ }^{\circ} 6.404$, de 15 d dezembro de 1976. Dispõe sobre as sociedades por ações. Disponível em <http://www.planalto.gov.br/ccivil_03/leis/16404consol.htm>. Acesso em: 02.11.2014) 
A mobilização da poupança popular e o seu encaminhamento voluntário para o setor empresarial exigem, contudo, o estabelecimento de uma sistemática que assegure ao acionista minoritário o respeito a regras definidas e eqüitativas, as quais, sem imobilizar o empresário em suas iniciativas, ofereçam atrativos suficientes de segurança $e$ rentabilidade." 183

Assim, a Lei n..$^{\circ}$ 6.404/76 previu uma modalidade de organização jurídica da empresa enquanto fato econômico, que não só dispõe de uma variedade de valores mobiliários que podem ser utilizados visando a sua capitalização, mas também prevê uma organização interna de seu sistema de poder, cujo fim é a dominação da própria empresa pelo controlador, sem prejuízo de assegurar ou, pelo menos, possibilitar a previsibilidade das decisões aos demais acionistas, viabilizando o atingimento dos objetivos e o exercício de sua função social, aliando técnica de governo da empresa ao exercício de seu poder de controle.

Por esta razão, o art. 116 da Lei n. ${ }^{\circ}$ 6.404/76 reconhece expressamente a existência da figura do acionista controlador, ou seja, do acionista detentor do poder de controle, que dirige as atividades da sociedade e orienta o funcionamento de seus órgãos internos, sempre com a finalidade de conduzir a sociedade para a realização do seu objeto social e ao cumprimento da sua função social, seja perante os demais acionistas e os empregados da sociedade, seja perante a comunidade na qual a sociedade atua (vide art. 116, parágrafo único, da Lei n. ${ }^{\circ} 6.404 / 76^{184}$ ).

Decorre da importância e da função, que é dotada de competências, poderes e deveres, atribuída ao acionista controlador, de estabelecer a política e os objetivos globais da empresa, enquanto detentor do poder de controle, a sua responsabilidade perante todos os demais participantes da companhia, a qual não se confunde com a

\footnotetext{
${ }^{183}$ Exposição de Motivos n. ${ }^{\circ}$ 196, de 24 de junho de 1976, do Ministério da Fazenda. Disponível em <http://www.cvm.gov.br/port/atos/leis/6404_Exposicao.asp>. Acesso em 17.11.2013.

184 "Parágrafo único. O acionista controlador deve usar o poder com o fim de fazer a companhia realizar o seu objeto e cumprir sua função social, e tem deveres e responsabilidades para com os demais acionistas da empresa, os que nela trabalham e para com a comunidade em que atua, cujos direitos e interesses deve lealmente respeitar e atender." (BRASIL. Lei n. ${ }^{\circ}$ 6.404, de 15 d dezembro de 1976. Dispõe sobre as sociedades por ações. Disponível em <http://www.planalto.gov.br/ccivil_03/leis/16404consol.htm〉. Acesso em: 02.11.2014)
} 
responsabilidade inerente a todos os acionistas e a todos os administradores conforme arts. 115 e 153 a 159, da Lei n. $^{\circ}$ 6.404/76, mas se trata de responsabilidade específica do acionista controlador, esta prevista nos arts. 116, parágrafo único, e 117 da Lei n. ${ }^{\circ}$ $6.404 / 76^{185}$.

Nesse sentido, segundo Eduardo Secchi Munhoz, "ao controlador deve ser atribuída a condição de empresário, representando um autêntico cargo na economia societária, ou seja, um centro de competência, que envolve funções determinadas, com poderes, deveres e responsabilidades próprios." ${ }^{186}$

Com efeito, como dispunha a Exposição de Motivos n. ${ }^{\circ}$ 196, de 24 de junho de 1976, do Ministério da Fazenda, nos comentários acerca da seção que tratava da alienação do controle, ao poder de controle é atribuído valor econômico que não se confunde com o preço das ações no mercado, mas se trata de valor econômico superior que reflete o valor do cargo de acionista controlador, que não só pode exercer os direitos ordinários de todos os acionistas, mas também inclui o "poder de determinar o destino da empresa, escolher seus administradores e definir sua política". ${ }^{187}$

Logo, dentro do sistema lógico existente na Lei n. ${ }^{\circ}$ 6.404/76, a companhia apresenta uma divisão de poderes-funções internamente.

Ao acionista controlador é atribuída a função social de estabelecer as diretrizes globais da sociedade por ações, a qual, inclusive, é expressão da livre

\footnotetext{
185 “'A Lei n. 6.404, de 1976, ao instituir a figura do controlador, faz desaparecer o princípio da igualdade de todos os acionistas, já que são eles separados em duas categorias: controladores e minoritários. Institui, com efeito, o controle como um órgão da companhia.

Cria, em consequência, o diploma de 1976 a responsabilidade do controlador, a par daquela dos acionistas em geral (art. 115) e dos administradores (arts. 153 a 159).

Em consequência, são os controladores responsáveis pela estrita observância dos deveres de lealdade, de diligência e de transparência; são responsáveis por condutas que contrariem tais princípios, além de deverem abster-se de praticar atos e negócios com desvio de poder e em conflito de interesses com a companhia.

Essa responsabilidade específica dos controladores, a qual, por isso, não se confunde com a dos acionistas em geal (art. 115) e a dos administradores (art. 153 a 159), advém da função, que lhes atribui a lei, de policy makers, ou seja, de estabelecerem, em caráter permanente, a polítca da companhia visando, a todo o tempo, ao interesse social." (CARVALHOSA, Modesto. Comentários à Lei das Sociedades Anônimas. Vol. 2. ${ }^{\circ}$. 5. edição. São Paulo: Saraiva, 2011, p. 605)

${ }^{186}$ MUNHOZ, Eduardo Secchi. Empresa Contemporânea e Direito Societário - Poder de Controle e Grupos de Sociedades. São Paulo: Juarez de Oliveira, 2002, p. 219.

187 Exposição de Motivos n. ${ }^{\circ}$ 196, de 24 de junho de 1976, do Ministério da Fazenda. Disponível em <http://www.cvm.gov.br/port/atos/leis/6404_Exposicao.asp>. Acesso em 17.11.2013.
} 
iniciativa $^{188}$, cujos valores sociais constituem fundamento da República Federativa do Brasil (art. $1^{\circ}{ }^{\text {, inciso IV, da Constituição Federal }}{ }^{189}$ ), bem como fundamento da Ordem Econômica (art. 170, caput, da Constituição Federal ${ }^{190}$ ).

Dentro do mencionado sistema lógico, além do poder-função de controle atribuído ao acionista controlador, "o legislador discriminou poderes-funções considerados fundamentais, atribuindo-os a órgãos próprios, insuprimíveis $e$ inconfundiveis: o poder-função deliberante à assembleia geral, o poder-função administrativo à diretoria, o poder-função sindicante ao conselho fiscal." ${ }^{191}$

Observe-se, novamente, que o poder de controle exercido pelo acionista controlador é um poder-função que, como bem ressaltou Fábio Konder Comparato, suplanta os demais poderes-funções atribuídos aos demais órgãos internos da companhia, apresentando ascendência hierárquica sobre os demais órgãos exercentes dos outros poderes-funções.

Assim, constata-se a indispensabilidade da figura do acionista controlador no âmbito do sistema de poder das sociedades por ações, independentemente de sua participação no capital social votante, isto é, a figura do acionista controlador é ínsita não só ao conceito de sociedade empresária tal como já visto anteriormente, mas também especificamente ao conceito de sociedade por ações, justamente por se tratar uma espécie de sociedade empresária.

\footnotetext{
188 “Assim, sinteticamente, é possível estabelecer a liberdade de iniciativa no campo econômico como construída pela liberdade de trabalho (incluídos o exercício das mais diversas profissões) e de empreender (incluindo o risco do empreendimento: o que produzir, como produzir, quanto produzir, qual o preço final), conjugada com a liberdade de associação, tendo como pressuposto o direito de propriedade, a liberdade de contratar e de comerciar."(TAVARES, André Ramos. Direito Constitucional Econômico. São Paulo: Método, 2003, p. 250)

189 “Art. $1^{\circ}$ A República Federativa do Brasil, formada pela união indissolúvel dos Estados e Municípios e do Distrito Federal, constitui-se em Estado Democrático de Direito e tem como fundamentos: (...)

IV - os valores sociais do trabalho e da livre iniciativa;" (Brasil. Constituição da República Federativa do Brasil de 1988. Disponível em http://www.planalto.gov.br/ccivil_03/constituicao/ConstituicaoCompilado.htm>. Acesso em 02.11.2014)

190 “Art. 170. A ordem econômica, fundada na valorização do trabalho humano e na livre iniciativa, tem por fim assegurar a todos existência digna, conforme os ditames da justiça social, observados os seguintes princípios:" (Idem, ibidem)

${ }^{191}$ COMPARATO, Fábio Konder; SALOMÃO FILHO, Calixto. O Poder de Controle na Sociedade Anônimas. 4. a edição. Rio de Janeiro: Forense, 2005, p. 30.
} 
A propósito, Eduardo Secchi Munhoz bem ressaltou a indispensabilidade do poder de controle no âmbito da sociedade empresária:

“Ora, sempre que há uma entidade coletiva organizada para o exercício de atividade, necessariamente, haverá poder de controle, ou seja, o poder de orientar a condução dessa atividade. Assim, se não há poder de controle, é porque não há organização coletiva, não se cogitando, portanto, da existência de empregador e de empregados e, por consequência, de poder diretivo." ${ }^{192}$

Logo, se não houver poder de controle, não se trata de sociedade empresária, tampouco de empresa (enquanto fenômeno econômico), visto que, segundo Ronald Coase, as empresas são caracterizadas pela existência de poder diretivo do empreendedor-coordenador, distinguindo-as de transações de trocas ocorridas no mercado, as quais, por sua vez, são direcionadas pelo mecanismo de preço que é um instrumento de coordenação, mas que não se confunde com a função exercida pelo empreendedorcoordenador.

Com efeito, o empreendedor-coordenador ao constituir uma sociedade empresária acaba por reduzir os custos de transação existentes nas transações ocorridas no mercado conforme o mecanismo de preço, justamente por alocar os recursos de maneira a proporcionar a redução dos custos, bem como por obter os fatores de produção a um custo menor que os custos das transações de mercado, in verbis:

"Externamente à empresa, os movimentos do preço direcionam a produção, que é coordenada por meio de uma série de transações de troca ocorridas no mercado. Dentro da empresa, estas transações de mercado são eliminadas e a complexa estrutura de mercado com transações de troca é substituída pelo empreendedor-coordenador, que dirige a produção." (tradução livre) ${ }^{193}$

\footnotetext{
${ }^{192}$ MUNHOZ, Eduardo Secchi. Empresa Contemporânea e Direito Societário - Poder de Controle e Grupos de Sociedades. São Paulo: Juarez de Oliveira, 2002, p. 218, nota 529.

193 "Outside the firm, price movements direct production, which is co-ordinated through series of exchange transactions on the market. Within a firm, these market transactions are eliminated and in place of
} 
"Podemos sintetizar esta seção de argumento dizendo que a operação de mercado custa algo e, ao constituir uma organização e permitir alguma autoridade (um 'empreendedor') para dirigir os recursos, certos custos do mercado são economizados. $O$ empreendedor tem de desempenhar sua função ao menor custo, considerando o fato de que ele pode obter fatores de produção a um preço inferior que os preços obtidos nas transações de mercado, os quais ele substitui, pois é sempre possível reverter ao mercado se ele falhar em fazer isto." (tradução livre) ${ }^{194}$

"Estas, então, são as razões pelas quais as organizações como as empresas existem em uma economia especializada de troca, na qual é geralmente presumido que a distribuição de recursos é 'organizada' pelo mecanismo do preço. Uma empresa, portanto, consiste em um sistema de relações que passa a existir quando a direção dos recursos passa a depender de um empreendedor." (tradução livre) ${ }^{195}$

Portanto, com o devido respeito às opiniões contrárias, mesmo que haja dispersão acionária, não há que se falar em desaparecimento da figura do acionista controlador, tal como defendido por Modesto Carvalhosa ${ }^{196}$.

O fato do acionista controlador possuir uma participação acionária aritmeticamente minoritária não o desqualifica como acionista controlador ${ }^{197}$, tanto que o

complicated market structure with exchange transactions is substituted the entrepreneur-co-ordinator, who directs production." (COASE, Ronald Harry. The Nature of the Firm. In: Economica, New Series, v. 4, n. ${ }^{\circ}$

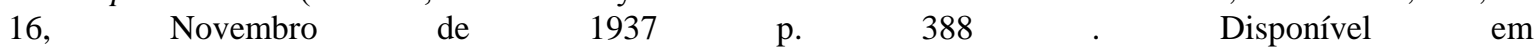
$<$ http://www.colorado.edu/ibs/eb/alston/econ4504/readings/The\%20Nature\%20of\%20the\%20Firm\%20by\%2 0Coase.pdf $>$. Acesso em 22.12.2012)

194 "We may sum up this section of the argument by saying that the operation of the market costs something and by forming an organization and allowing some authority (an 'entrepreneur') to direct the resources, certain marketing costs are saved. The entrepreneur has to carry out his function at less cost, taking into account the fact that he may get factors of production at a lower price than the market transactions which he supersedes, because it is always possible to revert to the open market if he fails to do this." (Idem, ibidem, $\mathrm{p}$. 392).

195 "These, then, are the reasons why organisations such as firms exist in a specialized exchange economy in which it is generally assumed that the distribution of resources is 'organised' by the price mechanism. A firm, therefore, consists of the system of relationships which comes into existence when the direction of resources is dependent on an entrepreneur." (Idem, ibidem, p. 393).

${ }^{196}$ A propósito veja: CARVALHOSA, Modesto. Comentários à Lei das Sociedades Anônimas. Vol. 2. ${ }^{\circ}$. 5. ${ }^{\text {a }}$ edição. São Paulo: Saraiva, 2011, p. 570 - 571; CARAHOSA, Modesto. A Dispersão Acionária e o Desaparecimento da Figura do Controlador. In: ROVAI, Armando Luiz \& MURRAY NETO, Alberto. As Sociedades por Ações na Visão Prática do Advogado. Rio de Janeiro, Elsevier, 2010, p. 1 - 6. 
mesmo será responsabilizado em caso de abuso do poder de controle, bem como perceberá o prêmio do controle em caso de alienação do poder de controle, independentemente de se tratar de um controlador totalitário, majoritário ou minoritário.

Deve-se ressaltar que o exercício do poder de controle não se limita ao exercício do direito de voto nas Assembleias Gerais, mas é muito mais amplo que o exercício do direito de voto, sendo este apenas uma seara do exercício do poder de controle no âmbito das companhias (e das sociedades empresárias).

O fato do legislador brasileiro não ter exigido uma porcentagem mínima de titularidade de ações com direito de voto, para qualificar o acionista como controlador, apenas confirma a possibilidade de haver acionista controlador aritmeticamente minoritário. ${ }^{198}$

Além disso, como bem observado por Alberto Asquini, analisando-se a empresa sob o perfil corporativo, conclui-se que a empresa é uma instituição, ou seja, uma organização social fundada em relações de hierarquia e cooperação que visa a um fim econômico comum, qual seja, “a obtenção do melhor resultado econômico, na produção." 199

A obtenção do resultado econômico socialmente útil somente é possível porque ao empresário-empreendedor, ou seja, ao controlador é atribuída a função organizativa e criadora de riqueza, cuja relevância econômica reside na capacidade de determinar a forma de distribuição e aplicação dos bens organizados e como será a produção de bens ou serviços, considerando, para tanto, as previsões adequadas que

197 “Com a formação das macrocompanhias com grande dispersão acionária, a ruptura entre poder empresarial e risco se estabeleceu, na medida em que o poder de controle societário passou a ser exercido por acionistas detentores de ações representativas de uma pequena parcela do capital (controle minoritário) (...) Ora, o acionista minoritário, em função da dispersão acionária, pode controlar a companhia com apenas $2 \%$ ou $3 \%$ do capital, ou seja, com um investimento proporcionalmente pequeno, comandando a orientação dos negócios sociais, sem assumir os riscos correspondentes." (MUNHOZ, Eduardo Secchi. Empresa Contemporânea e Direito Societário - Poder de Controle e Grupos de Sociedades. São Paulo: Juarez de Oliveira, 2002, p. 213)

198 "O legislador optou por não exigir a propriedade de percentual mínimo de ações votantes para caracterizar a figura do acionista controlador. Assim, deve ser examinada cada situação em particular para que possa ser detectado quem é o titular do controle acionário." (EIZIRIK, Nelson. A Lei das S/A Comentada. Vol. I. São Paulo: Quartier Latin, 2011, p. 668.)

199 ASQUINI, Alberto. Profili dell'impresa. Tração de Fábio Konder Comparato. In Revista de Direito Mercantil. São Paulo: Revista dos Tribunais, Ano XXXV, n. ${ }^{\circ}$ 104, Out-Dez/1996, p. 122. 
consideram os riscos técnicos e econômicos da empresa, que, segundo Alberto Asquini ${ }^{200}$, são, respectivamente os riscos relativos ao procedimento de produção e à possibilidade de pagar os custos de trabalho e os capitais empregados com os resultados obtidos pela produção dos bens ou serviços colocados no mercado.

Acrescente-se, ainda, que o poder de controle detido com participação aritmeticamente minoritária existe e é permitido dentro do sistema criado pela Lei ${ }^{\circ}{ }^{\circ}$ 6.404/76, tanto que é possível haver a limitação do número de votos de cada acionista por meio de previsão constante do estatuto social.

Com efeito, o $\S 1 .^{\circ}$ do art. 110 , da lei $.^{\circ} 6.404 / 76^{201}$, excepciona a regra constante do caput daquele artigo, que atribui a cada ação ordinária um voto nas deliberações a serem tomadas em assembleia geral, ao permitir que o estatuto social limite a quantidade de votos de cada acionista, de modo a deixar de haver correspondência à porcentagem de detenção de ações com direito a voto e o número de votos atribuídos aos titulares das ações votantes.

Conforme ensina a doutrina, esta previsão visa justamente a evitar que a vontade social seja substituída pela imposição da vontade individual do acionista controlador, in verbis:

“Ademais, de acordo com o $\$ 1 .{ }^{\circ}$, o estatuto pode estabelecer limitação ao número máximo de votos de cada acionista. Visa o dispositivo a instituir procedimento altamente benéfico para as minorias acionárias, minimizando o poder do bloco de controle e incentivando a 'pulverização' de ações, o que é salutar nas companhias abertas.",202

"A função dessa norma é impedir a concentração do poder de controle em um acionista e, consequentemente, proteger a minoria como ensina

\footnotetext{
200 ASQUINI, Alberto. Profili dell'impresa. Tração de Fábio Konder Comparato. In Revista de Direito Mercantil. São Paulo: Revista dos Tribunais, Ano XXXV, n. ${ }^{\circ}$ 104, Out-Dez/1996, p. 110 - 111.

201 “Art. 110. A cada ação ordinária corresponde 1 (um) voto nas deliberações da assembléia-geral.

$\S 1^{\circ} O$ estatuto pode estabelecer limitação ao número de votos de cada acionista." (BRASIL. Lei n. ${ }^{\circ}$ 6.404, de 15 d dezembro de 1976. Dispõe sobre as sociedades por ações. Disponível em <http://www.planalto.gov.br/ccivil_03/leis/16404consol.htm>. Acesso em: 02.11.2014)

${ }^{202}$ EIZIRIK, Nelson. A Lei das S/A Comentada. Vol. I. São Paulo: Quartier Latin, 2011, p. 627.
} 
Guimarães (1960, v. 2, p. 127). Segundo Comparato (1983, p. 144), representa defesa contra os processos de escalada ao poder nas companhias com grande dispersão acionária e controle minoritário." ${ }^{203}$

Logo, a limitação da quantidade de votos atribuída aos acionistas dá indícios de que a lei brasileira admitiu a existência do poder de controle aritmeticamente minoritário, o que é confirmado pela inexistência, na Lei n. ${ }^{\circ}$ 6.404/76, de exigência de participação mínima do acionista para que seja considerado controlador.

Com efeito, como bem pontuaram Alfredo Lamy Filho e José Luiz Bulhões Pedreira, "na fase de criação da empresa, a necessidade da função do empresárioempreendedor, exercida pelo acionista controlador, é óbvia (...) Mas essa necessidade continua a existir mesmo na empresa aberta que tem 50, 70, 90 ou 95\% do capital em mãos do público investidor. E a razão é simples: não há empresa que sobreviva sem estabilidade de direção, e é a existência do acionista controlador que cria essa estabilidade na companhia de mercado que não atingiu o estágio da macroempresa institucionalizada." 204

Observe-se que, mesmo atingindo o estágio de macroempresa, data venia, a existência do acionista controlador continua sedo indispensável para a continuidade das atividades negociais, pois, como bem ressaltaram Alfredo Lamy Filho e José Luiz Bulhões ${ }^{205}$, mesmo que acionista controlador detenha uma pequena porcentagem de ações com direito de voto, a legislação criou mecanismos que garantem ao acionista aritmeticamente minoritário a assunção do cargo de acionista controlador, bem como sua manutenção no tempo.

Além disso, a referida limitação proporciona a efetiva formação da vontade social, enquanto conjugação da vontade de todos os acionistas com direito de voto, não se

${ }^{203}$ LAMMY FILHO, Alfredo; PEDREIRA, José Luiz Bulhões. Direito das Companhias. Vol. I. Rio de Janeiro: Forense, 2009, p. 388.

${ }^{204}$ LAMY FILHO, Alfredo; PEDREIRA, José Luiz Bulhões. A Lei das S.A. Rio de Janeiro: Renovar, 1992, p. 193.

205 "Foi esse imperativo de ordem prática que obrigou a legislação de todos os países do mundo ocidental nos quais o mercado de ações alcançou alguma relevância, ou que procuram desenvolvê-lo, a admitir mecanismos que permitam a um acionista, ou grupo de acionistas, assumir e manter o controle, ainda que com pequena porcentagem do capital social. Sem falar na piramidação, nos sindicatos de votos, voting trusts, acordos de acionistas e outros recursos indiretos, há várias soluções adotadas para permitir a presença do acionista controlador". (Idem, ibidem, p, 194) 
limitando à imposição da vontade individual do acionista controlador, tampouco se confundindo com as vontades individuais dos acionistas ${ }^{206}$.

Desse modo, como bem indica o pronunciamento da Comission des Opérations de Bourse Francesa, "o interesse social é mais que um conceito, ele é uma referência, que não supõe uma identidade de visão, este é o ponto cardeal que une a ação majoritária com o interesse de todos os acionistas. "207 (tradução livre).

Com efeito, segundo o regime jurídico da sociedade por ações da Lei n. ${ }^{\circ}$ 6.404/76, a vontade social da companhia é formada pela convergência das vontades individuais dos acionistas, que somadas aos interesses extrassociais indicados no parágrafo único, do art. 116 da referida lei ${ }^{208}$, dará origem à vontade social, enquanto vontade da própria companhia, enquanto vontade superior e suprema em comparação às vontades individuais dos acionistas com direito de voto ${ }^{209}$.

Desta feita, em caso de companhias com controlador aritmeticamente minoritário, o exercício do poder de controle pode ser mais brando, conforme a intensidade da dominação detida pelo controlador, e uma maior autonomia de ação dos

\footnotetext{
${ }^{206}$ Segundo Luiz Gastão Paes de Barros Leães, o interesse social deve ser entendido "não como o somatório dos interesses privados dos sócios, nem como um interesse comum dos sócios (qua socii e não enquanto indivíduos), norteado no sentido da realização do objeto social" (LEÃES, Luiz Gastão Paes de Barros. Pareceres. Vol. I. São Paulo: Singular, 2004, p.176), o qual, nas palavras de Fran Martins, "se caracteriza pelas vantagens que podem advir para a sociedade, ainda mesmo que os atos praticados não se enquadrem perfeitamente dentro do objeto social da companhia. Não se confunde, assim, obrigatoriamente, com os interesses dos sócios ou acionistas da sociedade, às vezes até mesmo contrariando o interesse de alguns." (MARTINS, Fran. Comentários à Lei das Sociedades Anônimas. 4. ${ }^{a}$ edição. Rio de Janeiro: Forense, 2010, p. 575)

207 “'L'intérêt social est plus qu'un concept, c'est une référence,. Qui ne suppose pas l'identité de vue, c'est le point cardinal qui marie le fait majoritaire avec l'intérêt de tous les acionnaires". In: COMISSION DES OPÉRATIONS DE BOURSE. Bulletin Mensuel COB, n. 295, Oct. 1995, p. 35. Disponível em < http://www.amf-france.org/Publications/Revue-mensuelle-de-1-AMF/Bulletin-mensuel-de-laCOB/annee_1990-2003.html?docId=workspace\%3A\%2F\%2FSpacesStore\%2F2fa80582-5b25-41b7-a1ba9ebe4024036a>. Acesso em 02.11.2014.

208 “Art. 116. (...)

Parágrafo único. $O$ acionista controlador deve usar o poder com o fim de fazer a companhia realizar o seu objeto e cumprir sua função social, e tem deveres e responsabilidades para com os demais acionistas da empresa, os que nela trabalham e para com a comunidade em que atua, cujos direitos e interesses deve lealmente respeitar e atender." (BRASIL. Lei n. ${ }^{\circ}$ 6.404, de 15 d dezembro de 1976. Dispõe sobre as sociedades por ações. Disponível em <http://www.planalto.gov.br/ccivil_03/leis/16404consol.htm〉. Acesso em: 02.11.2014)

209 “(...) o interesse social não é, pois, a somatória dos interesses individuais de cada acionista, mas a transcendência desses mesmos interesses por um interesse comum a todos, definido no objetivo empresarial da companhia e nos seus fins sociais, qual seja, a sua prosperidade, representada pela contínua criação de valor."(CARVALHOSA, Modesto. Comentários à lei de Sociedades Anônimas. Vol. 2. 5. edição. São Paulo: Saraiva, 2011, p. 510)
} 
administradores será observada, o que não significa inexistência de poder de controle, tampouco atribuição do poder de controle aos administradores.

Acrescente-se, ainda, que, na atual sistemática da Lei n. ${ }^{\circ}$ 6.404/76, não é possível atribuir aos administradores o poder de controle denominado, na doutrina, de controle gerencial, em primeiro lugar, porque a titularidade do poder de controle somente é atribuível a titulares de direitos de sócio.

Dentre os titulares de direitos de sócio, estão não só os acionistas, mas também, por exemplo, os usufrutuários de ações, isto porque sendo constituído o usufruto de ações, o direito de voto poderá ser atribuído ao usufrutuário, que é um titular dos direitos de sócio, afastando-se a discussão se o mesmo seria, ou não, um acionista. A propósito, assim José Luiz Bulhões Pedreira e Alfredo Lamy Filho posicionam-se:

“O acionista controlador, em regra, tem a qualidade de acionista porque os direitos de voto são conferidos pelas ações a seus proprietários, mas a lei usa a expressão 'titular de direitos de sócio' para abranger a hipótese de esses direitos serem exercidos pelo usufrutuário das ações. $O$ direito de voto não pode ser transferido separadamente da propriedade da ação (v. § 103-6), mas a lei admite que o instrumento que institui usufruto possa atribuir o direito de voto ao usufrutuário, ao nuproprietário, ou distribuí-lo entre ambos (v. § 103-2); e como é controvertido se o usufrutuário é acionista, a lei refere-se a titular dos direitos de sócio para não deixar dúvida de que o usufrutuário que exerce o direito de voto (e o poder de controle) tem os deveres $e$ responsabilidades de acionista controlador.",210

Portanto, constata-se que o administrador não é um titular de direitos de sócio, o que por si só já afasta a possibilidade de transferir o poder de controle aos administradores em companhias com dispersão acionária, ou seja, segundo o regime jurídico brasileiro das companhias, não há possibilidade jurídica de existir o denominado poder de controle gerencial.

${ }^{210}$ LAMY FILHO, Alfredo; PEDREIRA, José Luiz Bulhões. Direito das Companhias. Vol. I. Rio de Janeiro: Forense, 2009, p. 815 - 816. 
Observe-se que a atuação dos administradores com maior autonomia, não implica em inexistência de poder de controle, que continua sendo exercido pelo acionista controlador aritmeticamente minoritário, mesmo que o seja de forma mais branda ou até que se constitua em um poder de controle latente. A propósito, John E. Parkinson assim se posiciona quanto ao poder de controle do acionista controlador aritmeticamente minoritário:

"Um grande acionista (por exemplo, o grupo Solvay com participação de 9,7 por cento de participação na Allied Chemical) não é considerado como tendo concedido o controle, em caso de ausência de participação regular na administração. Em vez disso, trata-se de uma evidência de poder latente, que serve como uma restrição na liberdade de ação da administração."211 (tradução livre)

Portanto, a autonomia de ação dos administradores não se confunde com detenção do poder de controle, que é destinado somente a titulares de direitos de sócio, espécie na qual os administradores não se enquadram, mesmo nos casos de companhias com dispersão acionária, nas quais o poder de controle pode ser exercido de maneira mais branda.

Ademais, se se admitisse a possibilidade do administrador exercer o denominado poder de controle gerencial, estar-se-ia admitindo burlar o regime jurídico das companhias, visto que aos mesmos não seria possível atribuir os deveres e as responsabilidades que são típicos e específicos dos acionistas controladores.

Não bastasse tudo isso, mesmo que o administrador possua certa liberdade e autonomia de ação, há que se ressaltar que sua influência dentro da estrutura organizacional hierárquica não lhe atribui todos os poderes típicos do acionista controlador, tampouco todos os caracteres de um controlador.

\footnotetext{
211 "A large shareholding (for example, the Solvay group's 9.7 per cent stake in Allied Chemical) is not regarded as giving control in the absence of regular participation in management. Rather it is treated as evidence of latent power, which serves as a constraint on management freedom of action." (PARKINSON, John E. Corporate Power and Responsability - Issues in the Theory of Company Law. Nova Iorque: Oxford University Press, 2002, p. 62)
} 
Isto porque a liberdade e a autonomia de ação dos administradores não são absolutas e imunes ao controle exercido pelo titular de direitos de sócio que detenha o poder de controle, tanto que a atuação dos administradores deve ser pautada pelas diretrizes globais traçadas pelo acionista controlador e dentro dos limites das deliberações sociais, sem prejuízo, obviamente, das normas estatutárias e da legislação.

O mesmo se pode dizer em relação ao chamado poder de controle externo, que a doutrina atribui a interessados que não são titulares de direitos de sócio, mas que de alguma maneira possuem uma influência nos rumos da sociedade por ações.

Assim, embora se deva admitir que interessados destituídos da qualidade de detentor dos direitos de sócio, tal como um credor da companhia, possam ter uma influência significativa em relação ao acionista controlador, justamente por haver uma relação de dominação-sujeição decorrente da obrigação patrimonial estabelecida entre ambos, não há que se falar que o interessado detém o poder de controle, simplesmente porque além de não ser titular de direitos de sócio, o mesmo sequer reúne os demais caracteres essenciais do acionista controlador.

Superada esta questão, deve-se acrescentar que mesmo que o acionista controlador seja aritmeticamente minoritário, não há que se falar em separação entre propriedade e controle, mas sim em separação entre propriedade e gestão.

Com efeito, como relatado por Idalberto Chiavenato ${ }^{212}$, a partir da Revolução Industrial percebe-se uma tendência nas empresas de substituição da administração efetuada pelos próprios proprietários das empresas, por administração realizada por administradores profissionais, mudança esta que teria sido motivada pelo aumento da complexidade dos negócios empresariais, que passaram a demandar uma maior especialização da mão de obra.

\footnotetext{
212 "Uma das grandes transformações que aconteceu após a Revolução Industrial, a qual se processou a partir do século XVIII, foi a gradativa substituição dos proprietários e homens de negócios por administradores profissionais no comando de suas empresas. Essa separação entre propriedade $e$ administração ocorreu porque a complexidade crescente das atividades empresariais obrigou seus proprietários a se afastarem do cotidiano dos negócios e deixá-los por conta de profissionais mais capazes de conduzir as atividades de suas empresas." (CHIAVENATO, Idalberto. Administração para Não

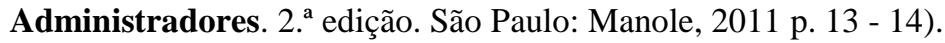


Dessa maneira, houve uma dissociação entre propriedade e gestão, jamais uma separação entre propriedade e poder de controle, este detido pelos próprios acionistas, ainda que o mesmo seja exercido de uma maneira mais branda, como bem indicou Nelson Eizirik ao tecer comentários acerca da teoria clássica da empresa:

“A teoria clássica da firma, desenvolvida por economistas neoclássicos, assume, implicitamente, que os direitos de propriedade são absolutamente privados. Na prática, aceita que tal ocorre muitas vezes, pelas limitações ou regulações estabelecidas aos direitos de propriedade privada, assim como pela existência de empresas públicas ou outros arranjos institucionais que atenuam os direitos de propriedade.

No caso da macroempresa, na medida em que tais restrições tendem a limitar o lucro dos proprietários diminui o incentivo destes em fazer valer seus direitos, aumentando por outro lado a oportunidade dos gerentes de maximizar suas funções de utilidade. No caso, porém, conforme esta linha de pensamento, teria havido apenas uma prévia relação contratual, pela qual os proprietários delegam a nãoproprietários - os gerentes - determinadas funções na exploração da atividade econômica. O que a dispersão de ações poderia operar, então, seria não uma supressão dos direitos de propriedade dos acionistas, mas, apenas uma atenuação em seus direitos de propriedade."213

Mais uma vez, não há como se confundir o exercício do poder de controle com a maior autonomia de atuação concedida aos administradores profissionais. A autonomia concedida aos administradores profissionais é inerente ao exercício da gestão empresarial, cuja tarefa primordial é interpretar as diretrizes globais estabelecidas pelos mecanismos organizacionais, transformando-as em ações concretas de gestão, com o fim único de atingir os objetivos estabelecidos da maneira mais eficiente possível, como bem ensinou Idalberto Chiavenato:

${ }^{213}$ EIZIRIK, Nelson. Propriedade e Controle na Companhia Aberta - Uma Análise Teórica. In Revista de Direito Mercantil. São Paulo: Revista dos Tribunais, Ano XXIII, n. ${ }^{\circ}$ 54, 1984, p. 97. 
"Segundo um ponto de vista mais amplo, a tarefa básica da administração consiste em interpretar os objetivos globais propostos pela organização e transformá-los em ação organizacional global por meio de planejamento, organização, direção e controle de todos os esforços realizados todas as áreas e em todos os níveis da empresa a fim de atingir tais objetivos da melhor maneira possível. Assim, a administração é o processo de planejar, organizar, dirigir e controlar a aplicação das competências e o uso dos recursos organizacionais para alcançar determinados objetivos de maneira eficiente e eficaz". ${ }^{214}$

Assim, o fato dos administradores profissionais deterem autonomia em sua atuação no exercício de uma parcela de poder hierárquico em relação aos demais profissionais atuantes na empresa em nível hierárquico inferior, não denota que possuem o poder de controle, como bem ressaltaram, inclusive, Adolf Berle Jr. e Gardiner C. Means ao analisarem a transformação da propriedade no âmbito das companhias, especialmente a divergência de interesses entre propriedade e controle:

"Da mesma forma, o termo controle deve limitar-se na prática àqueles que dominam os principais elementos de poder sobre uma empresa, tendo em mente, entretanto, que um grande número de indivíduos pode exercer um certo poder sobre as atividades de uma companhia sem dispor de poder suficiente que justifique sua inclusão no 'controle'.,215

Portanto, apesar de opiniões contrárias, constata-se que não há que se falar em separação entre propriedade e poder de controle, mas sim na separação entre propriedade e gestão da empresa, sem que haja a transferência do poder de controle aos administradores profissionais.

Além da detenção dos direitos de sócio, o acionista controlador deve ter influência dominante dentro da estrutura administrativa da empresa, ou seja, deve estabelecer uma relação social de dominação-sujeição em relação aos demais acionistas e

${ }^{214}$ CHIAVENATO, Idalberto. Administração para Não Administradores. 2. ${ }^{\text {a }}$ edição. São Paulo: Manole, 2011, p. $14-15$.

${ }^{215}$ BERLE Jr., Adolf Augustus; MEANS, Gardiner C. A Moderna Sociedade Anônima e a Propriedade Privada. 3. ${ }^{a}$ edição. São Paulo: Nova Cultural, 1988, p. 124. 
administradores da companhia, de modo a agregar uma força organizadora das atividades com um fim de executar o objeto social da companhia e atingir os fins estabelecidos.

Conforme observou Fábio Konder Comparato, ao analisar a legislação alemão de 1965, "essa influência sobre a sociedade nada mais é do que uma das manifestações do poder de controle" 216 , a qual, justamente, contribuirá para que o acionista controlador, ainda que seja aritmeticamente minoritário, consiga obter a estabilidade e continuidade do exercício do poder de controle dentro da companhia, irradiando seu poder de controle sobre todos os órgãos internos, não somente nas Assembleias Gerais.

Apesar do legislador brasileiro ter indicado no art. 116, alínea "a", da Le n. 6.404/76, que o acionista controlador deve ser "titular de direitos de sócio que lhe assegurem, de modo permanente, a maioria dos votos nas deliberações da assembleia geral e o poder de eleger a maioria dos administradores da companhia", o exercício do poder de controle não ocorre somente nas deliberações das assembleias gerais.

Com efeito, como já visto anteriormente neste trabalho, o acionista controlador encontra-se no ápice da estrutura organizacional da empresa, apresentando ascendência hierárquica sobre todos os demais órgãos internos da empresa, de modo que o acionista controlador, nos termos da terminologia usada por Adolf Berle e Gardiner Means, exerce verdadeira força centrípeta ${ }^{217}$.

Isto porque o acionista controlador tem a função primordial de, com base na propriedade econômica dos frutos do trabalho e na propriedade jurídica dos meios de produção, organizar os meios de produção, os capitais investidos e a mão de obra para exercer a atividade econômica da companhia da maneira mais eficiente e que envolva menor risco, proporcionando a maior lucratividade possível, sem deixar de compor os diversos interesses envolvidos na companhia.

Para tanto, o acionista controlador deve observar a vontade social formada e externada nas deliberações da assembleia geral, a qual não se confunde com a vontade

216 COMPARATO, Fábio Konder. Poder de Controle na Sociedade Anônima. In Revista de Direito Mercantil. São Paulo: Revista dos Tribunais, Ano XII, n. ${ }^{\circ}$ 9, 1973, p.71.

${ }^{217}$ BERLE Jr., Adolf Augustus; MEANS, Gardiner C. A Moderna Sociedade Anônima e a Propriedade Privada. 3. ${ }^{a}$ edição. São Paulo: Nova Cultural, 1988, p. 37. 
pessoal do controlador, pois as deliberações assembleares devem resultar da concorrência da manifestação das vontades de todos os acionistas, que, inclusive, devem estar em consonância com o objeto social da companhia e com sua função social, de modo que jamais poderá ser o resultado da imposição da vontade do acionista controlador, o que, inclusive, contrariaria a concepção de formação da vontade social dentro das sociedades por ações, que, aliás, deve observar as diretrizes gerais estabelecidas pelo controlador.

Cabe ao acionista controlador, enquanto detentor de ascendência hierárquica, convencer os demais acionistas de que suas sugestões são as melhores e estão em conformidade com as diretrizes globais da companhia, apresentando adequação à vontade social que será formada por meio da deliberação assemblear, ou seja, cabe ao controlador exercer seu poder de persuasão e dominação, sem, contudo, subverter o procedimento assemblear de formação da vontade social.

Justamente, por isso, o exercício do poder de controle não se limita às deliberações assembleares, mas extrapola o âmbito da Assembleia Geral, e irradia-se sobre toda a organização administrativa da companhia, chegando até a irradiar-se no âmbito externo da própria companhia.

Nesse sentido, ensina José Alexandre Tavares Guerreiro que "como os eleitores-acionistas têm poder de vida e morte sobre a administração, podendo a qualquer tempo destituir qualquer administrador em caráter discricionário, fácil é de perceber que, do ângulo sociológico, o poder de controle se projeta para além do foro assemblear, impondo-se sobre a administração como uma força coativa de caráter permanente, condicionando a gestão dos administradores-eleitos. Infiltra-se, dessa forma, o poder de controle pela própria tessitura organizacional da administração, influindo de facto nos rumos da empresa, como uma potestas efetiva. Tal é, pelo menos, uma possibilidade propiciada pelo sistema legal, ainda que de forma não-explícita."218

Dessa forma, embora a alínea "a", do art. 116 da Lei n. ${ }^{\circ}$ 6.404/76 disponha que o controlador deve ter assegurados a maioria de votos nas assembleias gerais e o poder de eleger a maioria dos administradores de modo permanente, deve-se levar em

${ }^{218}$ GUERREIRO, José Alexandre Tavares. Sociedade Anônima: Poder e Dominação. In Revista de Direito Mercantil. São Paulo: Revista dos Tribunais, Ano XXIII, n. ${ }^{\circ}$ 53, Jan-Mar/1984, p. 75 - 76. 
consideração que, em uma companhia com capital aberto e disperso, tornar-se mais difícil assegurar constantemente a maioria de votos em assembleias gerais e eleição da maioria dos administradores, visto que, geralmente, o acionista controlador de uma companhia com capital aberto disperso é aritmeticamente minoritário, portanto, mais sujeito à não prevalência em deliberações assembleares e à impossibilidade de eleição da maioria dos administradores.

Todavia, com o devido respeito às opiniões dissonantes, esta é uma característica das companhias com capital aberto e disperso, que pode se fazer presente, ou não, conforme o acionista controlador consiga exercer um poder de dominação sobre a estrutura organicional.

Mas, mesmo não obtendo a maioria de votos em deliberações das assembleias gerais e não conseguindo eleger a maioria dos administradores, entendemos que isto não desnatura a figura do acionista controlador, justamente porque o exercício do poder de controle não se limita às deliberações assembleares, mas, ao contrário, irradia-se para além das assembleias gerais, cuja competência está delimitada pelo rol do art. 122 da Lei n. ${ }^{\circ} 6.404 / 76^{219}$, que elenca as matérias de competência privativa da assembleia geral.

Frise-se que as decisões tomadas em assembleia geral devem observar o interesse da companhia, visando não só sua defesa, mas também seu desenvolvimento, interesse aquele que deverá estar em conformidade com as diretrizes globais fixadas pelo controlador no exercício de sua atividade organizadora (de bens, de capital e de mão de obra) e criadora de riqueza.

\footnotetext{
219 “Art. 122. Compete privativamente à assembleia geral:

I - reformar o estatuto social;

II - eleger ou destituir, a qualquer tempo, os administradores e fiscais da companhia, ressalvado o disposto no inciso II do art. 142;

III - tomar, anualmente, as contas dos administradores e deliberar sobre as demonstrações financeiras por eles apresentadas;

IV - autorizar a emissão de debêntures, ressalvado o disposto no § 1 o do art. 59;

IV - autorizar a emissão de debêntures, ressalvado o disposto nos $\$ \S 10,20$ e 40 do art. 59;

$V$ - suspender o exercício dos direitos do acionista (art. 120);

VI - deliberar sobre a avaliação de bens com que o acionista concorrer para a formação do capital social;

VII - autorizar a emissão de partes beneficiárias;

VIII - deliberar sobre transformação, fusão, incorporação e cisão da companhia, sua dissolução e liquidação, eleger e destituir liquidantes e julgar-lhes as contas; $e$

IX - autorizar os administradores a confessar falência e pedir concordata." (BRASIL. Lei n. ${ }^{\circ} 6.404$, de $15 \mathrm{~d}$ dezembro de 1976. Dispõe sobre as sociedades por ações. Disponível em <http://www.planalto.gov.br/ccivil_03/leis/16404consol.htm>. Acesso em: 02.11.2014)
} 
Assim, nas palavras de José Alexandre Tavares Guerreiro, "nas macroestruturas empresariais contemporâneas, o fenômeno burocrático cumpre seu papel de instrumentalizar o exercício efetivo do poder (Macht) com o propósito de realizar a dominação (Herrschaft), no plano concreto. As resoluções isoladas e tópicas da assembleia geral de acionistas, em que se faz patente o poder de controle, se completam por uma constante influência dominante do acionista controlador, senhor dos rumos da companhia, dirigente real das atividades sociais e orientador das deliberações dos órgãos de gestão." 220

Ademais, ainda que a maioria dos administradores não seja eleita pelo controlador, este não deixará de deter o poder de controle, visto que os administradores eleitos, ao assumirem o cargo na administração da companhia, devem exercer suas funções não em conformidade com os interesses do grupo de acionistas eleitor, mas, sim, de acordo com o interesse da companhia, as exigências do bem público e da função social da sociedade por ações, sendo expressamente proibido o atendimento aos interesses particulares dos acionistas que o elegeram, conforme determinam o caput e $\S 1 .^{\circ}$ do art. 154, da Lei n. ${ }^{\circ} 6.404 / 76^{221}$.

Logo, os administradores, ao exercerem suas atividades de gestão, atenderão ao interesse da companhia formado pelas deliberações da assembleia geral, as quais, por sua vez, seguirão as diretrizes gerais estabelecidas pelo controlador.

Portanto, a previsão do art. 116, alínea “a”, da Lei n. ${ }^{\circ}$ 6.404/76, que determina que o acionista controlador deve de modo permanente deter a maioria dos votos em assembleia geral e o poder de eleger a maioria dos administradores, deve ser interpretada sistematicamente com a alínea "b" e o caput daquele dispositivo legal, como forma de permitir sua adaptação à recente realidade brasileira de dispersão acionária e às características típicas de controle aritmeticamente minoritário.

\footnotetext{
${ }^{220}$ GUERREIRO, José Alexandre Tavares. Sociedade Anônima: Poder e Dominação. In Revista de Direito Mercantil. São Paulo: Revista dos Tribunais, Ano XXIII, n. ${ }^{\circ}$ 53, Jan-Mar/1984, p. 77.

221 “Art. 154. O administrador deve exercer as atribuições que a lei e o estatuto lhe conferem para lograr os fins e no interesse da companhia, satisfeitas as exigências do bem público e da função social da empresa.

$\S 1^{\circ} \mathrm{O}$ administrador eleito por grupo ou classe de acionistas tem, para com a companhia, os mesmos deveres que os demais, não podendo, ainda que para defesa do interesse dos que o elegeram, faltar a esses deveres." (BRASIL. Lei n. ${ }^{\circ}$ 6.404, de 15 d dezembro de 1976. Dispõe sobre as sociedades por ações. Disponível em <http://www.planalto.gov.br/ccivil_03/leis/16404consol.htm>. Acesso em: 02.11.2014)
} 
Dessa forma, o acionista controlador, nos termos da alínea "b", do art. 116 da Lei n. ${ }^{\circ} 6.404 / 76$, deve exercer efetivamente o poder de dirigir as atividades sociais e de orientar o funcionamento dos órgãos internos da companhia, poderes estes que decorrem diretamente da ascendência hierárquica que o acionista controlador possui, o que não poderia ser diferente, pois o acionista controlador, na vigente lei, é reconhecido como verdadeiro órgão pertencente à organização administrativa da sociedade por ações, o qual se encontra no ápice da sua estrutura organizacional.

Nesse sentido, inclusive, Mauro Rodrigues Penteado afirma que " $a$ Lei $n{ }^{o}$ 6.404/76 trouxe para o proscênio jurídico a figura do detentor do poder de controle da companhia, pessoa física ou jurídica, reconhecendo nessa quarta instância societária como que um novo órgão, onde reside o verdadeiro poder político da companhia.,"222

Apesar de opiniões contrárias ${ }^{223}$, o exercício efetivo do poder de controle deve ser exigido de todo e qualquer acionista controlador, seja ele pessoa física, seja ele sociedade nos termos do art. $243, \S 3 .^{\circ}$, da Lei . $^{\circ} 6.404 / 76$, isto porque o fato do controlador ser uma sociedade, não o exime de exercer efetivamente o poder de controle, pois este requisito não se confunde com a simples previsão, em seu contrato social ou estatuto social, de que seu objeto será a administração de outras sociedades, pois estes documentos constitutivos são externos à companhia que controla e, ainda, tal previsão não se confunde com o efetivo exercício do poder de controle internamente na companhia que controla.

\footnotetext{
${ }^{222}$ Apontamentos sobre a Alienação do Controle de Companhias Abertas. In Revista de Direito Mercantil. São Paulo: Revista dos Tribunais, Ano XXVIII, n. ${ }^{\circ}$ 76, Dez - 1989, p. 15.

${ }^{223}$ A propósito, Mauro Rodrigues Penteado sintetiza as correntes doutrinárias acerca da necessidade, ou não, do efetivo exercício do poder de controle: "Diante desses dispositivos, exsurge a dúvida: o exercício efetivo do poder de controle é elemento integrativo da definição de acionista controlador e da sociedade controladora, ou esse atributo é inerente a quem detenha a maioria das ações votantes?

A resposta a essa indagação dividiu os doutrinadores. De um lado alinharam-se aqueles que entendem que o uso efetivo do poder de controle é indispensável à caracterização tanto do acionista controlador, quanto da sociedade controladora, chegando alguns autores a asseverar que no art. 243 houve 'flagrante omissão do texto legislativo'. Uma corrente intermediária sustenta que a prova do uso efetivo do poder de controle sóé necessária para identificar o acionista controlador - pessoa física, sendo dispensável no relacionamento intersocietário, para caracterizar a sociedade controladora ou de comando, visto que em tais hipóteses o referido exercício é sempre presumido ou suposto.

Por derradeiro, há uma terceira posição doutrinária, que a nosso ver de forma acertada julga necessária a comprovação do uso efetivo do poder de controle apenas no caso de controle minoritário, posto que a detenção da maioria das ações votantes sempre pressupõe o status de acionista controlador ou de sociedade controladora ou de comando." (Idem, ibidem, p. 16)
} 
Assim, o exercício efetivo do poder de controle expressamente suplanta o exercício do direito de voto nas deliberações da assembleia geral e o poder de eleger a maioria dos administradores, de modo que a permanência exigida pela alínea "a", do art. 116, da Lei n. ${ }^{\circ}$ 6.404/76, deve ser entendida como exigência de efetivo exercício do poder de controle de modo constante, conferindo estabilidade a todos os órgãos da estrutura organizacional da companhia.

A mencionada estabilidade não é atingida apenas com a constante detenção da maioria de votos em assembleia geral e eleição da maioria dos administradores, visto que estes dois aspectos do exercício do poder de controle não são os únicos, havendo outros aspectos do exercício do poder de controle, tais como, por exemplo, a agregação de força organizadora dos diversos interesses, a coordenação das atividades da empresa, o exercício de um sistema de controle e punição administrativa, ainda que seja exercido por meio da delegação a outrem distinto do próprio controlador, a orientação dos diversos órgãos internos, que agregados compõem o exercício efetivo e constante do poder de controle, ainda que em dada deliberação não se tenha obtido a maioria dos votos ou, ainda, não se tenha obtido êxito na eleição da maioria dos administradores.

A propósito, Alfredo Lamy Filho e José Luiz Bulhões Pedreira pontuam que o exercício do poder de controle reveste-se de diversas formas, in verbis:

"O exercício do poder do acionista controlador pode revestir formas diversas, embora não excludentes, e se manifesta através de diferentes espécies de atos: (a) nas matérias de competência privativa da Assembleia Geral, ou submetidas à sua deliberação, sob forma de voto; (b) se o acionista controlador cumula suas funções com as de administrador, sob a forma de atos de administração; $e$ (c) ainda que não administrador eleito, sob forma de ordens aos órgãos de administração e fiscalização.

O reconhecimento de que o poder do acionista controlador não se manifesta, apenas, através do voto nas Assembleias Gerais, conduziu à aceitação de um conceito mais abrangente do abuso de poder, para 
incluir todas as modalidades desse abuso, quando do exame do ato por ele praticado." 224

Logo, pode-se perceber que o poder de controle não é instrumentalizado somente por meio do exercício do direito de voto nas deliberações assembleares, mas também há outros meios de instrumentalização do exercício do poder de controle internamente, de forma que se mostra, hodiernamente, desarrazoado exigir do controlador a detenção permanente da maioria de votos nas deliberações da Assembleia Geral e do poder de eleger a maioria dos administradores, especialmente em um ambiente de dispersão acionária, no qual o acionista controlador detém uma participação aritmeticamente minoritária, nem sempre suficiente para garantir a maioria de votos nas deliberações sociais.

O próprio art. $117, \S 1 .^{\circ}$, da Lei n. ${ }^{\circ} 6.404 / 76^{225}$, em suas diversas alíneas, ao regular a responsabilidade do acionista controlador por atos de abuso do poder de controle,

${ }^{224}$ LAMY FILHO, Alfredo; PEDREIRA, José Luiz Bulhões. A Lei das S.A. Rio de Janeiro: Renovar, 1992, p. 463.

225 "Art. 117. O acionista controlador responde pelos danos causados por atos praticados com abuso de poder.

$\S 1^{\circ}$ São modalidades de exercício abusivo de poder:

a) orientar a companhia para fim estranho ao objeto social ou lesivo ao interesse nacional, ou levá-la a favorecer outra sociedade, brasileira ou estrangeira, em prejuízo da participação dos acionistas minoritários nos lucros ou no acervo da companhia, ou da economia nacional;

b) promover a liquidação de companhia próspera, ou a transformação, incorporação, fusão ou cisão da companhia, com o fim de obter, para si ou para outrem, vantagem indevida, em prejuízo dos demais acionistas, dos que trabalham na empresa ou dos investidores em valores mobiliários emitidos pela companhia;

c) promover alteração estatutária, emissão de valores mobiliários ou adocão de políticas ou decisões que não tenham por fim o interesse da companhia e visem a causar prejuízo a acionistas minoritários, aos que trabalham na empresa ou aos investidores em valores mobiliários emitidos pela companhia;

d) eleger administrador ou fiscal que sabe inapto, moral ou tecnicamente;

e) induzir, ou tentar induzir, administrador ou fiscal a praticar ato ilegal, ou, descumprindo seus deveres definidos nesta Lei e no estatuto, promover, contra o interesse da companhia, sua ratificação pela assembléia-geral;

f) contratar com a companhia, diretamente ou através de outrem, ou de sociedade na qual tenha interesse, em condições de favorecimento ou não equitativas;

g) aprovar ou fazer aprovar contas irregulares de administradores, por favorecimento pessoal, ou deixar de apurar denúncia que saiba ou devesse saber procedente, ou que justifique fundada suspeita de irregularidade.

h) subscrever ações, para os fins do disposto no art. 170, com a realização em bens estranhos ao objeto social da companhia. (Incluída dada pela Lei $n^{\circ} 9.457$, de 1997)

$\S 2^{\circ}$ No caso da alínea e do $\$ 1^{o}$, o administrador ou fiscal que praticar o ato ilegal responde solidariamente com o acionista controlador.

$\S 3^{\circ} \mathrm{O}$ acionista controlador que exerce cargo de administrador ou fiscal tem também os deveres $e$ responsabilidades próprios do cargo." (BRASIL. Lei n. ${ }^{\circ} 6.404$, de 15 d dezembro de 1976. Dispõe sobre as sociedades por ações. Disponível em <http://www.planalto.gov.br/ccivil_03/leis/16404consol.htm>. Acesso em: 02.11.2014) 
exemplificativamente, indicado atos que são praticados pelo controlador e que, portanto, escapam da alçada da assembleia geral, como "orientar a companhia" (alínea 'a'), adotar política ou decisões (alínea 'c'), influenciar os administradores e fiscais (alínea 'e') e contratar (alínea ' $\mathrm{f}$ ').

Para tanto, deve-se levar em conta que o acionista controlador possui também o poder de influência, o poder de determinar a política interna dos negócios e seus rumos etc., sempre dentro de uma perspectiva de exercer estes poderes visando à consecução dos fins e objetivos da companhia, sem deixar de respeitar a função social da companhia, a vontade social formada, bem como respeitar e atender, com lealdade, os interesses e direitos dos demais acionistas, dos colaboradores da companhia e da comunidade em que a sociedade por ações atua, conforme prevê o parágrafo único, do art. 116 da Lei n. ${ }^{\circ} 6.404 / 76^{226}$.

Decorre, assim, que o acionista controlador necessita exercer efetivamente o poder de controle, mas não há necessidade de permanentemente deter a maioria de votos nas deliberações sociais, tampouco o poder de eleger a maioria dos administradores, como meio de obter a estabilidade ${ }^{227}$.

Será muito relevante que o acionista controlador (especialmente o controlador aritmeticamente minoritário) e, consequentemente, toda a administração consigam ter estabilidade no exercício de suas atividades, como meio de garantir a gestão da empresa visando a atingir objetivos de curto, médio e longo prazos, para o que não só o controlador, mas a administração ${ }^{228}$ como um todo possa $(i)$ definir os objetivos e os meios a serem utilizados para que os mesmos sejam atingidos da maneira mais eficiente

226 “Art. 116. (...)

Parágrafo único. O acionista controlador deve usar o poder com o fim de fazer a companhia realizar o seu objeto e cumprir sua função social, e tem deveres e responsabilidades para com os demais acionistas da empresa, os que nela trabalham e para com a comunidade em que atua, cujos direitos e interesses deve lealmente respeitar e atender." (BRASIL. Lei n. ${ }^{\circ}$ 6.404, de $15 \mathrm{~d}$ dezembro de 1976. Dispõe sobre as sociedades por ações. Disponível em <http://www.planalto.gov.br/ccivil_03/leis/16404consol.htm〉. Acesso em: 02.11.2014)

227 "Como se verá a seguir, o controle só pode representar valor da organização empresarial quando gerar poder estável sobre ela". (COMPARATO, Fábio Konder; SALOMÃO FILHO, Calixto. O Poder de Controle na Sociedade Anônimas. 4. a edição. Rio de Janeiro: Forense, 2005, p. 70)

${ }^{228}$ Segundo Idalberto Chiavenato, "a administração é o processo de planejar, organizar, dirigir e controlar a aplicação das competências e o uso dos recursos organizacionais para alcançar determinados objetivos de maneira eficiente e eficaz." (CHIAVENATO, Idalberto. Administração para Não Administradores. 2. edição. São Paulo: Manole, 2011, p. 15) 
(planejamento), (ii) proceder à divisão dos trabalhos, atribuindo as respectivas responsabilidades (organização), (iii) influenciar e motivar os colaboradores na execução de suas tarefas (direção) e (iv) exercer o monitoramento das atividades dos colaboradores subalternos para, sendo necessários, proceder às correções (monitoramento), tudo com o objetivo de atingir as metas estabelecidas eficiente e eficazmente.

Mas a obtenção da estabilidade pode ocorrer por outros meios, que não a detenção da maioria dos votos em deliberações assembleares e do poder de eleger a maioria dos administradores, não fazendo sentido alegar que a detenção da maioria absoluta de votos de modo permanente conferiria, somente ao acionista controlador, o poder de destituir a maioria dos administradores e, por isso, conferiria também a estabilidade ao poder de controle e consequentemente à administração, tal como afirmado por Modesto Carvalhosa:

“A expressão 'de modo permanente' contida no presente dispositivo quer significar que existe um acionista ou um grupo deles que, possuindo $50 \%$ mais uma das ações votantes, não poderá ser destituído do seu direito de eleger a maioria dos administradores por parte de qualquer outro grupo de acionistas e que, por isso mesmo, efetivamente exerce, sempre esse direito. Essa maioria absoluta do capital votante outorga, outrossim, ao controlador o direito de, sempre, deliberar majoritariamente em matérias próprias das assembleias gerais. E reveste a administração por ele eleita do caráter de estabilidade, na medida em que a maioria dos seus membros somente poderá ser destituída por ele, controlador." 229

Data maxima venia, deve-se observar que a competência de destituir os administradores e fiscais da sociedade por ações é atribuída expressamente à Assembleia Geral, conforme dispõe o art. 122, inciso II, da Lei n. ${ }^{\circ} 6.404 / 76^{230}$, bem como é atribuída

\footnotetext{
${ }^{229}$ CARVAlHOSA, Modesto. Comentários à Lei das Sociedades Anônimas. Vol. 2. ${ }^{\circ}$. 5. ${ }^{\text {a }}$ edição. São Paulo: Saraiva, 2011, p. 574.

230 “Art. 122. Compete privativamente à assembleia geral:

(...)

II - eleger ou destituir, a qualquer tempo, os administradores e fiscais da companhia, ressalvado o disposto no inciso II do art. 142;" " (BRASIL. Lei.$^{0}{ }^{\circ} 6.404$, de 15 d dezembro de 1976. Dispõe sobre as sociedades por ações. Disponível em <http://www.planalto.gov.br/ccivil_03/leis/16404consol.htm>. Acesso em: 02.11.2014)
} 
ao Conselho de Administração a competência de nomear e destituir os diretores da companhia nos termos da redação do art. 142, inciso II, também da retro mencionada lei ${ }^{231}$, de maneira que estas competências não são atribuídas ao acionista controlador, o qual, por sua vez, basta deter influência sobre a Assembleia Geral e sobre o Conselho de Administração para dominá-los, sem, necessariamente, ter de deter a maioria absoluta dos votos e o poder de eleger maioria dos administradores.

Com efeito, a estabilidade tanto do poder de controle e, por consequência da administração, pode ser obtido por outros meios, tanto que o próprio Modesto Carvalhosa, em outra passagem de sua obra, reconhece que a expressão "de modo permanente" utilizada por aquele dispositivo legal quer significar que "a lei exige permanência ('de modo permanente'), ou seja, estabilidade, continuidade no tempo do uso do poder deliberativo para dirigir as atividades sociais e orientar o funcionamento dos órgãos da companhia.",232

Assim, a referida estabilidade não é obtida apenas pela detenção da maioria absoluta dos votos e do poder de eleger a maioria dos administradores. Também é possível obter esta estabilidade por meio da celebração de acordo de acionistas, da adoção de medidas defensivas do poder de controle e por normas de governança corporativa.

Com efeito, havendo um poder de controle aritmeticamente minoritário, é possível que o acionista controlador celebre acordo de acionistas ${ }^{233}$ com outros acionistas, como forma de regular o exercício do direito de voto e, desse modo, reforçar seu poder de

231 “Art. 142. Compete ao conselho de administração:

(...)

II - eleger e destituir os diretores da companhia e fixar-lhes as atribuicões, observado o que a respeito dispuser o estatuto; ;" (BRASIL. Lei n. ${ }^{\circ}$ 6.404, de 15 d dezembro de 1976. Dispõe sobre as sociedades por ações. Disponível em <http://www.planalto.gov.br/ccivil_03/leis/16404consol.htm>. Acesso em: 02.11.2014) ${ }^{232}$ CARVAlhoSA, Modesto. Comentários à Lei das Sociedades Anônimas. Vol. 2. ${ }^{\circ}$. 5. ${ }^{\text {a }}$ edição. São Paulo: Saraiva, 2011, p. 577.

${ }^{233}$ Tendo em vista que não constitui objeto deste trabalho analisar as medidas adotadas por acionista controlador aritmeticamente minoritário, sobre este tema são indicados as seguintes obras e artigos: CARVAlhoSA, Modesto. Acordo de Acionistas: Homenagem a Celso Barbi Filho. 1. ${ }^{a}$ edição. São Paulo: Saraiva, 2011; ABRÃ̃O, Eduardo Lysias Maia. Acordos de Acionistas Típicos e Atípicos. 1. ${ }^{a}$ edição. Curitiba: Juruá, 2011; FRANCISCO, André Marques et al.. Análise Jurídica das Chamadas Poison Pills Brasileiras. In: PENTEADO, Mauro Rodrigues \& Munhoz, Eduardo Secchi Munhoz. Mercado de Capitais Brasileiro: Doutrina, Cases \& Materials. 1. a edição. São Paulo: Quartier Latin, 2012; PRADO, Roberta Nioac. Desconcentração do Poder de Controle e Poison Pills: Evolução no Mercado de Capitais Brasileiro. In: CASTRO, Rodrigo R. Monteiro de \& AZEVEDO, Luís André N. de. Poder de Controle e Outros Temas de Direito Societário e Mercado de Capitais. 1. a edição. São Paulo: Quartier Latin, 2010. 
controle ou até constituir um poder de controle detido conjuntamente por vários acionistas aritmeticamente minoritários, conforme permite o art. 118 da Lei n. ${ }^{\circ} 6.404 / 76^{234}$.

Outro mecanismo utilizado hodiernamente para reforçar o poder de controle aritmeticamente minoritário são as denominadas poison pills, que são medidas defensivas do poder de controle, ou seja, medidas que reforçam a detenção do poder de controle e, portanto, afastam a possibilidade de tomada hostil e/ou de escalada em bolsa de valores em ambientes corporativos de dispersão acionária. Em outras palavras, "as poison pills ou 'pílulas de veneno' são instrumentos de proteção adotados pelas companhias com o objetivo de dificultar a aquisição do controle oriunda de uma oferta hostil, objetivando também o tratamento igualitário entre os acionistas."235

Com a adoção destas medidas defensivas do poder de controle, mesmo tratando-se de um poder de controle aritmeticamente minoritário, o acionista controlador reforçará seu poder de controle adquirindo estabilidade necessária e, portanto, atribuindo-a também à administração para que seja possível o exercício da atividade econômica de modo estável e com o objetivo de atingir a consecução de seu objeto social e da sua função social.

A propósito, nesse sentido são, respectivamente, os ensinamentos de Roberta Nioac Prado e André Marques Franscisco et al.:

“Além disso, podem ser relevantes na medida em que conferem estabilidade à administração, necessária na maior parte das vezes quando da transição de companhia fechada para companhia aberta."236

\footnotetext{
${ }^{234}$ Art. 118. Os acordos de acionistas, sobre a compra e venda de suas ações, preferência para adquiri-las, exercício do direito a voto, ou do poder de controle deverão ser observados pela companhia quando arquivados na sua sede." (BRASIL. Lei n. ${ }^{\circ}$ 6.404, de 15 d dezembro de 1976. Dispõe sobre as sociedades por ações. Disponível em <http://www.planalto.gov.br/ccivil_03/leis/16404consol.htm>. Acesso em: 02.11.2014)

${ }^{235}$ FRANSCISCO, André Marques et al. Análise Juridica das Chamadas Poison Pills Brasileiras. In: PENTEADO, Mauro Rodrigues \& MUNHOZ, Eduardo Secchi. Mercado de Capitais Brasileiro: Doutrina, Cases \& Materials. São Paulo: Quartier Latin, 2012, p. 69.

${ }^{236}$ PRADO, Roberta Nioac. Desconcentração do Poder de Controle e Poison Pills: Evolução no Mercado de Capitais Brasileiro. In: CASTRO, Rodrigo R. Monteiro de \& AZEVEDO, Luís André N. de. Poder de Controle e Outros Temas de Direito Societário e Mercado de Capitais. São Paulo: Quartier Latin, 2010, p. 400 .
} 
"Diante das considerações apresentadas, podemos afirmar que as poison pills brasileiras caracterizam-se como cláusulas estatutárias, de natureza organizativa, disciplinadoras das relações envolvendo alterações na composição acionária das companhias. Esses mecanismos podem ser licitamente utilizados para: (i) defender a companhia contra tentativas de tomada hostil de controle, como se dá no mercado norteamericano; (ii) resguardar o processo de dispersão do controle da companhia; (iii) garantir a estabilidade temporária da administração da companhia durante momentos de dificuldade financeira."237

Por fim, outra forma de se conferir estabilidade à administração e ao próprio poder de controle consiste na adoção de normas de governança corporativa), enquanto conjunto de regras e diretrizes sintetizadoras de boas práticas de governo de empresa, não só nas relações internas da companhia, mas também em suas relações externas.

As regras de governança corporativa disciplinam $(i)$ as relações internas entre os diversos agentes interessados na companhia, estabelecendo um sistema de relação e um conjunto de direitos nas relações entre acionistas majoritário e minoritário, bem como entre acionistas e administradores, (ii) as estruturas de poder da companhia, inclusive o sistema de direção, controle e fiscalização ao estabelecer um sistema de governo e estruturas do poder da companhia, bem como (iii) o sistema de valores e de padrões de comportamentos dos interessados na companhia, que são fundados basicamente nos pilares do senso de justiça no trato dos acionistas minoritários (fairness), da plena informação ou transparência das informações da empresa (full disclosure), da prestação responsável de contas (accountability) e do cumprimento do sistema jurídico (compliance).

Assim, as normas de governança corporativa ${ }_{s}$ dentre outros efeitos, possuem o condão de atribuir à administração o dever de agir com neutralidade, de modo a evitar a mudança de acionista controlador e, consequentemente, da própria administração, como bem pondera Nilson Lautenschleger Júnior:

${ }^{237}$ FRANCISCO, André Marques et al.. Análise Jurídica das Chamadas Poison Pills Brasileiras. In: PENTEADO, Mauro Rodrigues \& Munhoz, Eduardo Secchi Munhoz. Mercado de Capitais Brasileiro: Doutrina, Cases \& Materials. São Paulo: Quartier Latin, 2012, p. 86. 
"O fato é que a neutralidade da administração é vista como condição necessária para o desenvolvimento de um mercado de controle sadio e funcional, que, por sua vez, garanta uma administração engajada no objetivo de lucratividade da companhia. Trata-se de lógica simples. Se houver um mercado de transferência de controle os administradores serão obrigados a atentar para o desempenho da companhia, sob pena de a mesma ser adquirida por concorrentes ou outros investidores interessados na margem de lucro propiciada pelo baixo valor de cotação das ações da companhia. O mercado de transferência de controle atuaria, assim, como um equalizador de interesses e obrigaria a administração a se voltar para o desempenho da companhia de forma a evitar uma mudança de controle que acarretaria, ao certo, a mudança da administração."238

Logo, pode-se perceber que as normas de governança corporativa, quando adotadas pela companhia, acabam por reforçar o poder de controle e, consequentemente, conferem estabilidade ao poder de controle e à própria administração, justamente por exigir uma atuação eficaz, dotada de neutralidade e de lisura da administração, especialmente quanto à tentativa de mudança do poder de controle, servindo, portanto, como outra forma de reforço do poder de controle aritmeticamente minoritário.

Aliando-se tais mecanismos de defesa e reforço do poder de controle, constata-se que o exercício do poder de controle aritmeticamente minoritário não requer indispensavelmente que o acionista controlador detenha a maioria absoluta dos votos, tampouco o poder de eleger a maioria dos administradores, aspectos estes que são superados pelo efetivo exercício do poder de controle e pela orientação do funcionamento dos órgãos internos, além da ascendência hierárquica dentro da estrutura organizacional da sociedade por ações, o que seguramente proporcionará ao controlador o estabelecimento de influência dominante e, assim, de uma relação social de dominação-sujeição internamente na companhia.

${ }^{238}$ LAUTENSCHLEGER JÚNIOR, Nilson. Os Desafios Propostos pela Governança Corporativa ao Direito Empresarial Brasileiro. São Paulo: Malheiros, 2005, p. 100 - 101. 
Portanto, com o devido respeito, não assiste razão à doutrina que afirma que o poder de controle aritmeticamente minoritário é caracterizado pela falta de permanência de pela instabilidade não só do próprio poder de controle, mas também da administração, de modo a não se caracterizar como poder de controle propriamente dito ${ }^{239}$, pois é possível deter o poder de controle mesmo que seja com base na titularidade minoritária de ações com direito a voto, como bem expressou Fábio Konder Comparato:

“(...) em determinadas macro-companhias de capital aberto, dado o absenteísmo ou desinteresse da maior parte dos acionistas, é matematicamente possível dominar-se assembleia com menos da metade das ações votantes (controle chamado minoritário)."240

Isto porque, caso o poder de controle aritmeticamente minoritário eventualmente apresente uma propensão à instabilidade, há medidas de defesa e de reforço do poder de controle como visto acima, que conferem a estabilidade necessária não só ao poder de controle, mas também à administração da companhia com ações dispersas, de modo a proporcionar uma maior influência e dominação em relação a toda a estrutura organizacional da sociedade por ações, pois, como bem ressaltou Modesto Carvalhosa, o exercício efetivo do poder de controle tem o condão de caracterizar o poder de controle, não somente a aptidão para comandar, in verbis:

“A aptidão de comandar não configura o controle. O que identifica essa posição de privilégio e responsabilidade legal (arts. 117 e 245) é o efetivo exercício desse poder de impor a política e os quadros de administração das sociedades, direta ou indiretamente, controladas. Ou

239 Veja a propósito a posição de Modesto Carvalhosa: "Assim, os blocos de ações minoritárias caracterizam-se pela impermanência, do que resulta a sua incapacidade de comandar a sociedade. E essa impermanência acarreta, necessariamente, uma instabilidade no exercício da administração, levando a uma interdependência precária entre os administradores que, efetivamente, nas companhias com capital disperso, comandam e determinados grupos de acionistas minoritários. A qualquer momento, as investidas de outros blocos minoritários podem acarretar a mudança do governo da companhia, exercida pelos seus atuais administradores." (CARVALHOSA, Modesto. Comentários à Lei das Sociedades Anônimas. Vol. 2. . 5. a edição. São Paulo: Saraiva, 2011, p. 579)

240 COMPARATO, Fábio Konder. Poder de Controle na Sociedade Anônima. In Revista de Direito Mercantil. São Paulo: Revista dos Tribunais, Ano XII, n. ${ }^{\circ}$ 9, 1973, p. 71. 
seja, não é a possibilidade de exercício majoritário ou minoritário de comando que caracteriza o controle, mas sua efetividade."241

Ademais, o fato do controlador aritmeticamente minoritário não possuir prevalência absoluta nas deliberações sociais não o desqualifica como acionista controlador, pois, como já visto anteriormente, o exercício do poder de controle suplanta a prevalência nas deliberações assembleares e o poder de eleger a maioria dos administradores.

${ }^{241}$ CARVALHOSA, Modesto. Comentários à Lei das Sociedades Anônimas. Vol. 4. ${ }^{\circ}$, Tomo II. 4. ${ }^{\mathrm{a}}$ edição. São Paulo: Saraiva, 2011, p. 41. 


\section{O PODER DE CONTROLE NA DOUTRINA E NA LEGISLAÇÃO ESTRANGEIRAS}

Feita a verificação dos principais caracteres do poder de controle nas sociedades por ações, conforme a legislação brasileira, cumpre verificar quais são as características essenciais do poder de controle no Direito estrangeiro, especialmente no Direito Norte-americano, que é tradicionalmente marcado pela alta dispersão acionária, bem como no Direito Comunitário Europeu, que congrega países marcados não só pela concentração da participação acionária, como, por exemplo, na França, mas também pela dispersão, tal como ocorre no Reino Unido.

Após a análise do Direito Comunitário Europeu, serão estudados o Direito Francês e o Direito Inglês quanto aos caracteres do poder de controle nas sociedades por ações.

A modesta pretensão deste estudo cinge-se ao levantamento das características essenciais do poder de controle das sociedades por ações para, em comparação com o Direito Brasileiro, constatar-se quais são os elementos essenciais que definem o poder de controle, especialmente em um ambiente de dispersão acionária, servindo, como bem ensinou Tulio Ascarelli, de "auxílio para a interpretação e a aplicação de um determinado direito, tal como, aliás, acontece em geral com os estudos históricos e sociológicos" ${ }^{242}$, ou seja, servindo de base interpretativa do Direito Brasileiro diante desta incipiente realidade de dispersão acionária.

Permite-se a utilização da experiência estrangeira como base interpretativa do Direito Brasileiro, porque, segundo André Tunc, "a sociedade anônima é o instrumento típico do capitalismo"243 e, por isso, "o direito das sociedades anônimas é um domínio que

242 ASCARELli, Tullio. Problemas das Sociedades Anônimas e Direito Comparado. Campinas: Bookseller, 2001, p. 45.

243 "L'importance du droit des sociétés anonymes n'est plus à démontrer. La société anonyme est l'instrument typique du capitalisme." (TUNC, André. Le Droit Américain Des Sociétés Anonymes. Paris: Economica, 1985, p. 5) 
nos mostra ser particularmente útil de observar o que é feito no estrangeiro" ${ }^{\text {244 }}$, pois "em matéria de sociedades, encontra-se o mesmo gênero de problemas em todos os países industrializados", uma vez que "as práticas, elas mesmas se difundem muito rapidamente de uma país a outro" ${ }^{245}$.

Por fim, como bem afirma André Tunc, em matéria de companhias, "é preciso, por isso, considerar as experiências estrangeiras, pois os problemas que frequentemente são apontados são mais ou menos e identicamente os mesmos, com alguns anos de diferença às vezes, em Londres, em Nova Iorque, em Paris, em Dusseldorf ou em Tóquio." ${ }^{246}$ (tradução livre)

\footnotetext{
244 “Or, le droit des sociétés anonymes est un domaine où il nous semble particulièrement utile d'observer ce qui se fait à l'étrager." (TUNC, André. Le Droit Américain Des Sociétés Anonymes. Paris: Economica, 1985, p. 6)

245 "C'est qu'en matière de sociétés, on retrouve le même genre de problèmes dans tus les pays industrialisés (...) Les pratiques elles-mêmes se répandent très vite d'un pays à l'autre." (Idem, ibidem, p. 6)

246 "Et il fault, pour cela, considérer les expériences étrangères, car les problèmes, quoi qu'on en ait souvent dit, sont à peu près identiquement les mêmes, avec quelques années de décalage parfois, à Londres, à New York, à Paris, à Dusseldorf ou à Tokyo."(TUNC, André. Le Droit Anglais Des Sociétés Anonymes. 2. ${ }^{a}$ edição. Paris : Dalloz, 1978, p.1)
} 


\subsection{O DIREITO NORTE-AMERICANO}

André Tunc, Professor Emérito da Universidade de Paris I, desenvolveu um estudo jurídico comparado sobre as sociedades por ações, analisando o regime jurídico deste tipo societário em outros países, tais como, por exemplo, Reino Unido e Estados Unidos da América.

Em relação ao Direito Norte-americano ${ }^{247}$, a importância, em matéria de sociedades por ações, é notória, ocupando um lugar de destaque não só em razão do poder econômico das empresas, mas em virtude do alto grau de desenvolvimento do mercado de capitais e da intensa utilização dos valores mobiliário como forma de captação da poupança pública.

Consoante os ensinamentos de André Tunc:

"Mais importante ainda é a qualidade do direito americano das sociedades anônimas e de valores mobiliários. Este direito está constantemente à procura de soluções melhores. Ele foi particularmente inovador quando, para colocar um fim ao abuso que foi revelado pela crise da bolsa de 1929 e que a causou em grandes proporções, adotou as leis federais de 1933 e 1934."248

Assim, não bastasse tais motivos reveladores da importância do estudo do Direito Norte-americano em relação às sociedades por ações, trata-se de país que possui tradicionalmente um alto grau de dispersão acionária.

No que se refere ao conceito de acionista controlador, este, no direito norteamericano, possui um direito de propriedade e, desse modo, assume deveres fiduciários perante os demais acionistas e os próprios administradores, pois se os administradores

\footnotetext{
${ }^{247}$ TUNC, André. Le Droit Américain Des Sociétés Anonymes. Paris: Economica, 1985.

248 "Plus importante encore est la qualité du droit américain des sociétés anonymes et des valeurs mobilières. Ce droit est constantement à la recherche de meilleures solutions. Il a été particulièrement innmovateur lorsque, pour mettre fin aux abus qu'avait révélé la crise boursière de 1929 et qui l'avaient largement causée, ont été prises les lois fédérales de 1933 et 1934." (Idem, ibidem, p. 7)
} 
assumem deveres fiduciários, o acionista controlador, por maior razão, também os assume tendo em vista o poder que o acionista controlador possui sobre os administradores e os demais acionistas, bem como em razão de ser o controlador quem controla ou, ainda, exerce a direção efetiva da companhia.

A atribuição de deveres fiduciários ao acionista controlador justifica-se, igualmente, pelo poder que o controlador tem de decidir a sorte dos demais acionistas, de forma que o poder detido pelo controlador deve ser exercido para a consecução do objetivo comum, o que requer um exercício leal, justo e equânime do poder de controle, visando ao benefício de todos os acionistas.

Consoante a definição trazida pelo $§ 5.02$ do Principles of Corporate Governance: Analysis and Recommendations ${ }^{249}$, projeto este que foi elaborado pela American Law Institute e foi publicado em sua primeira versão em 1981, o acionista será considerado como controlador se, individualmente ou por força de um acordo celebrado com outra ou outras pessoas, (a) for titular de mais de 50\% (cinquenta por cento) dos valores mobiliários em circulação com direito de voto ou que lhe confere um poder de voto sem reservas, ou (b) de fato controlar a gestão dos negócios.

Ainda, segundo o $§ 5.02$ do Principles of Corporate Governance, o referido projeto presume ser controlador o acionista que detiver, individual ou conjuntamente, $25 \%$ (vinte e cinco por cento) ou mais dos valores mobiliários em circulação com direito de voto ou que lhe confira o poder de votar sem reservas.

No âmbito da legislação federal norte-americana, não há uma definição específica de poder de controle, mas é possível encontrar nas leis federais indicações do que é considerado acionista controlador para os efeitos de uma norma específica.

249 "§ 5.02. Actionnaire dominant

Un 'actionaire dominant' est un actionnaire qui, soit seul, soi en vertu d'un arrangement ou d'un accord avec une ou plusiers autres personnes :

(1) Possède plus de 50\% des valeurs em circulation (outstanding) ayant le droit de vote, ou qui a sur elles um pouvoir de vote sans réserve, ou

(2) En fait, contrôle la gstion des affaires (the management of the business) oude l'opération particulière en cause. Un actonaire qui, seul ou en vertu d'un arrangement ou d'un accord avec une ou plusieurs autres personnes, possède $25 \%$ ou plus des valeursen circulation ayant le droit de vote, ou qui a sur elles un pouvoir de vote sans réserve, est présumé contrôler la gestion des affaires."

(Disponível em < http://www.ali.org/index.cfm?fuseaction=publications.ppage\&node_id=88>). 
Nesse sentido, é possível constatar que o Securities Act of 1933, que regulamenta a oferta e a venda de valores mobiliários, traz na Section 15 - Liability of Controlling Persons, alínea (a) ${ }^{250}$, uma definição de controlador, segundo a qual são controladores "toda pessoa que, por ou através da propriedade de ações, agência, ou outra forma, ou que, de acordo com ou em conexão com um acordo ou entendimentos com uma ou mais pessoas ou por meio da propriedade de ações, agência, ou outro meio, controla qualquer pessoa (....)."

Em conexão ao dispositivo acima transcrito, há a norma 405, do Regulamento C - Registro da Securities and Exchange Comission ${ }^{251}$, a qual define o termo controle. Nos termos da norma 405, "o termo controle (incluindo os termos controlador, controlado por e sob o controle comum de) significa a titularidade, direta ou indireta, do poder de dirigir ou determinar a direção da administração e da política da pessoa, por meio da propriedade de valores mobiliários com direito a voto, por contrato ou outra forma".

Ainda, ao longo das disposições do Securities Exchange Act de $1934^{252}$, que regula as transações efetuadas com valores mobiliários no mercado de valores mobiliários, pode-se extrair elementos que, ao serem unidos, acabam fornecendo alguns elementos caracterizadores do acionista controlador.

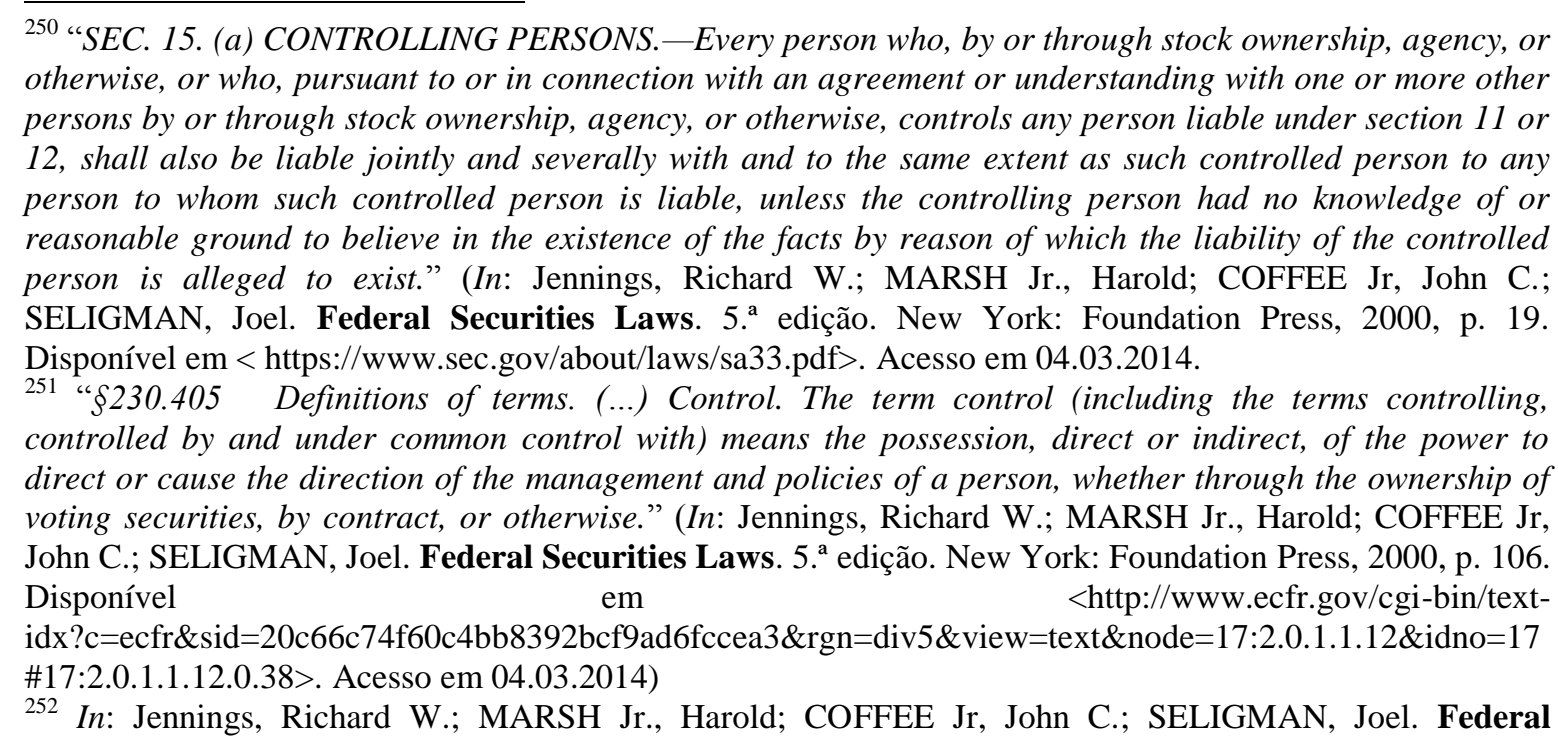

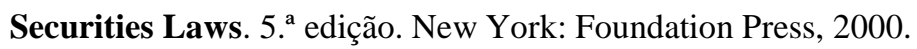


Com efeito, na Section 3 - Definitions and Application, que traz um rol de definições a serem aplicadas às demais disposições da norma, em seu item $(9)^{253}$, dispõe que o termo pessoa será considerado como sendo a pessoa natural, a pessoa jurídica, o governo, subdivisão, agência ou outros órgãos governamentais.

Já, em seu item $(21)^{254}$, ao conceituar os termos pessoa associada a um membro ou pessoa associada de um membro, indica, ao final, que pode significar "qualquer sócio, empregado, diretor ou gerente de filial daquele membro (ou qualquer pessoa ocupando uma posição similar ou executando funções similares), qualquer pessoa direta ou indiretamente controladora, controlada por ou sob controle comum com aquele membro, ou qualquer empregado daquele membro."

Mais adiante, na Section 20 - Liabilities of Controlling Persons and Persons Who Aid and Abet Violations, a alínea (a) ${ }^{255}$, ao regular a responsabilidade das pessoas controladoras e das pessoas que ajudaram ou induziram a prática de violação, dispõe que "toda pessoa que, direta ou indiretamente, controla qualquer pessoa responsável sob qualquer provisão deste título ou qualquer regra ou regulamento será também responsável (...)."

Em outra norma federal, no Investment Company Act of 1940, pode-se encontrar nova definição de controle. De acordo com a redação do item (9), do título de

\footnotetext{
253 “(9) The term 'person' means a natural person, company, government, or political subdivision agency, or instrumentality of a government."(In: Jennings, Richard W.; MARSH Jr., Harold; COFFEE Jr, John C.; SELIGMAN, Joel. Federal Securities Laws. 5. ${ }^{a}$ edição. New York: Foundation Press, 2000, p. 502. Disponível em < https://www.sec.gov/about/laws/sea34.pdf>. Acesso em 04.03.2014)

254 “(21) The term 'person associated with a member' or 'associated person of a member' when used with respect to a member of a national securities exchange or registered securities association means any partner, officer, director, or branch manager of such member (or any person occupying a similar status or performing similar functions), any person directly or indirectly controlling, controlled by, or under common control with such member, or any employee of such member."(Idem, ibidem, p. 504)

255 "Sec. 20. (a) Every person who, directly or indirectly, controls any person liable under any provision of this title of any rule or regulation thereunder shall also be liable jointly and severally with and to the same extent as such controlled person to any person to whom such controlled person is liable, unless the controlling person acted in good faith and did not directly or indirectly induce the act of acts constituting the violation or cause of action." (Idem, ibidem, p. 623)
} 
definições gerais ${ }^{256}$, daquele diploma legal, “'controle' significa o poder de exercer uma influência controladora sobre a administração ou sobre a política da companhia (....)"

No âmbito da legislação estadual, de acordo com o Delaware General Corporation Law $^{257}$, o item n. ${ }^{\circ} 4$, da alínea “c”, do $\S 203$, do Subcapítulo VI, do Capítulo 1 , do Título $8^{258}$, que cuida da transferência de ações conceitua o poder de controle como sendo "a posse direta ou indireta do poder de dirigir ou de conduzir a direção do gerenciamento e das políticas internas, através da detenção da propriedade de ações votantes, por contrato ou de outra forma", sendo presumida a qualidade de acionista controlador quando o acionista detiver $20 \%$ (vinte por cento) ou mais dos valores mobiliários em circulação com direito de voto.

Dessa maneira, a partir das disposições acima mencionadas, pode-se constatar que o acionista controlador pode ser uma pessoa, física ou jurídica, incluindo órgão governamental, que, direta ou indiretamente, detenha, individual ou conjuntamente com outra ou outras pessoas, o poder de dirigir, determinar a direção da administração de uma companhia e de determinar a sua política interna ou, ainda, exercer uma influência controladora sobre a administração e a política de uma companhia, seja por meio da titularidade de ações (ou outros valores mobiliários) dotados de direito de voto ou por contrato ou, ainda, por outro modo, presumindo-se a detenção do poder de controle a partir da titularidade de ações com direito de voto representativas de $20 \%$ (vinte por cento) ou mais do capital social.

256 "(9) "Control" means the power to exercise a controlling influence over the management or policies of a company, unless such power is solely the result of an official position with such company." (Disponível em <http://www.sec.gov/about/laws/ica40.pdf>. Acesso em 04.03.2014)

${ }^{257}$ A escolha do Direito Corporativo de Delaware deve-se ao fato de que o Estado de Delaware, embora seja um pequeno Estado norte-americano, é reconhecido mundialmente pela expertise de seus magistrados em matéria de direito empresarial e, em especial, em matéria relativa a companhias abertas, o que, inclusive, proporcionou a concentração de um grande número de companhias com ações quotadas na Bolsa de Nova Iorque e na NASDAQ.

258 " $\$ 203$ Business combinations with interested stockholders. (...) (c) (...) (4) 'Control', including the terms 'controlling', 'controlled by' and 'under common control with', means the possession, directly or indirectly, of the power to direct or cause the direction of the management and policies of a person, whether through the ownership of voting stock, by contract or otherwise. A person who is the owner of $20 \%$ or more of the outstanding voting stock of any corporation, partnership, unincorporated association or other entity shall be presumed to have control of such entity, in the absence of proof by a preponderance of the evidence to the contrary; Notwithstanding the foregoing, a presumption of control shall not apply where such person holds voting stock, in good faith and not for the purpose of circumventing this section, as an agent, bank, broker, nominee, custodian or trustee for 1 or more owners who do not individually or as a group have control of such entity." (Disponível em <http://delcode.delaware.gov/title8/c001/sc06/index.shtml>. Acesso em 04.03.2014) 
Por fim, cabe mencionar que, segundo Gerald F. Davis e Tracy A. Thompson, a detenção do poder de controle com pequena titularidade de ações com direito a voto deve-se, primordialmente, à regulamentação existente, que impõe aos acionistas detentores de uma participação acionária superior a 5\% (cinco por cento) a obrigação de fornecer diversas informações por meio de formulários, além de sujeitar os acionistas detentores de uma participação igual ou superior a $10 \%$ (dez por cento) às normas aplicáveis ao insider trading, especialmente à necessária declaração mensal das aquisições de ações e à responsabilidade por atos ilegais, como, por exemplo, a responsabilidade decorrente da prática de fraude com valores mobiliários.

Nesse sentido afirmam Gerald F. Davis e Tracy A. Thompson:

"Uma explicação com maior credibilidade para a passividade do acionista é o fato de o acionista institucional estar tolhido por uma rede complexa de normas legais que torna mais difícil, caro e legalmente arriscado deter a titularidade de uma grande porcentagem de participação ou empreender esforços conjuntos (Black, 1990: 523) (...) O conjunto de acionistas visando a influenciar a administração conjuntamente seria considerado como um 'grupo' pela definição da SEC e portanto tornar-se-iam sujeitos à elaboração de formulários se os acionistas detivessem conjuntamente mais de 5 por cento das ações da empresa. Claro, se o grupo não detivesse mais de 5 por cento, ele não teria muita influência. Se o grupo detivesse 10 por cento ou mais, seus membros sujeitar-se-iam às regras do insider trading, sendo solicitadas informações mensais de suas aquisições e vendas das ações da companhia, assim como às responsabilidades por oscilações do lucro. A nomeação e eleição de um diretor também torna uma instituição em insider. E alcançando o status de acionista controlador, que é bem definido, poderia sujeitar uma instituição à responsabilidade por atos ilegais tais como prática de fraude com valores mobiliários pela própria companhia (Black, 1990; Roe, 1991)."259

${ }^{259}$ Tradução livre de: "A far more credible explanation for shareholder passivity is the fact that "institutional shareholders are hobbled by a complex web of legal rules that make it difficult, expensive, and legally risky to own large percentage stakes or undertake joint efforts" (Black, 1990: 523). Until late 1992, 
Logo, a dispersão acionária típica dos Estados Unidos é movida, principalmente, pelas disposições regulamentares, não se tratando de um movimento natural do mercado de valores mobiliários norte-americano rumo à dispersão acionária.

communications aimed at influencing the votes of more than 10 other shareholders had to be examined and approved by the Securities and Exchange Commission (SEC) several days in advance. Sets of shareholders seeking to influence management jointly would count as a "group" by the SEC's definition and therefore would become subject to elaborate filing requirements if they collectively owned more than 5 percent of the firm's shares. Of course, if the group did not own more than 5 percent, it would be unlikely to have much influence. If the group owned 10 percent or more, its members would be subject to insider-trading rules requiring monthly disclosures of their purchases and sales of company stock as well as liabilities for "short swing" profits. Nominating and electing a director also makes an institution an "insider." And achieving status as a "controlling person," which is quite broadly defined, could subject an institution to liability for illegal acts such as securities fraud committed by the company itself (Black, 1990; Roe, 1991). Again, corporate managers have sought to maintain the autonomy that this legally mandated separation of ownership and control gave them, most recently by lobbying the SEC through the Business Roundtable (Black, 1990: fn. 161)." (DAVIS, Gerald F.; THOMPSON, Tracy A.. A Social Movement Perspective on Corporate Control. In: Administrative Science Quarterly, v. 39, $\mathrm{n}^{\circ}$ 1, 1994, p. 148. Disponível em < http://webuser.bus.umich.edu/gfdavis/Papers/A\%20Social\%20Movement.pdf>. Acesso em 09.06.2013) 


\subsection{O DIREITO COMUNITÁRIO EUROPEU}

No âmbito da Comunidade Europeia, segundo Rafael Perez Escolar ${ }^{260}$, a sociedade anônima europeia, também conhecida por apenas Societas Europea (S.E.) surgiu como uma categoria jurídica de sociedade empresária de abrangência interestatal, dotada de personalidade jurídica, com os objetivos de restabelecer a dimensão e a importância da Comunidade Europeia em termos de fatores de produção e de comercialização, como forma de não limitar à satisfação apenas das necessidades locais, mas, sim, de proporcionar uma união das empresas e fortalecê-las com meios de ação e de capacidade competitiva no âmbito comunitário (e não somente local), sujeitando-as a um regime jurídico único e aplicável a todos os Estados membros da Comunidade Europeia.

A sociedade anônima europeia funda-se na ideia de autoridade que necessariamente leva à criação de órgãos internos executores desta autoridade, nos termos do procedimento previsto em seu estatuto social, além de implicar irremediavelmente na ideia de desigualdade entre os acionistas, de subordinação segundo uma hierarquia organizacional e diferenciação, uma vez que "os direitos subjetivos dos indivíduos, típicos na esfera contratual são minimizados no direito institucional. O todo é superior às partes. ${ }^{, 261}$

Assim, a sociedade anônima europeia, embora esteja fundada na ideia de autoridade funcional, proporciona a integração efetiva dos trabalhadores no processo decisório da companhia ${ }^{262}$, proporcionando a participação efetiva de seus representantes em órgãos decisões da sociedade anônima europeia, mas sem descurar da preponderância do interesse social, de modo que a companhia europeia foi desenvolvida visando à reunião e estabilização de diversos interesses, inclusive interesses antagônicos, de maneira equilibrada.

\footnotetext{
${ }^{260}$ In: La Sociedad Anónima Europea. Madrid: Montecorvo, 1972, p. 86.

261 "Los derechos subjetivos de los individuos, típicos en la esfera contractual son minimizados en el derecho institucional. El todo es superior a las partes." (ESCOLAR, Rafael Perez. La Sociedad Anónima Europea. Madrid: Montecorvo, 1972, p. 81)

${ }^{262}$ A propósito do tema, vide Diretiva 2001/86/CE do Conselho da Comunidade Europeia, de 08.10.2001, publicada no Diário Oficial das Comunidades Europeias de 11.10.2001, L 294/22, a qual cuida das medidas de implicação dos trabalhadores nas decisões empresariais a serem adotadas como modelo europeu único. Disponível em <http://eur-lex.europa.eu/LexUriServ/LexUriServ.do?uri=CELEX:32001L0086:FR:NOT>. Acesso em 09.03.2014.
} 
Além das características supra indicadas, a sociedade anônima europeia funda-se, basicamente, em dois pilares fundamentais: a transmissibilidade dos títulos mobiliários que conferem a titularidade dos direitos de sócio e a continuidade da administração.

Segundo a doutrina europeia, a sociedade anônima europeia teria sido concebida de modo que a direção efetiva não deveria ser atribuída ao próprio empreendedor, mas sim a administradores dotados de alta especialização, cuja incumbência primordial é dar pleno cumprimento ao objeto social da companhia. Assim, o capital $^{263}$ teria apenas como funções internas (i) a eletiva na nomeação dos administradores, bem como (ii) a de servir de módulo quantitativo e qualitativo em relação aos direitos e faculdades dos acionistas.

Dessume-se, assim, que a estrutura da sociedade anônima europeia apresenta um caráter técnico, visto que os administradores não são os grandes acionistas, os quais são representados no conselho de administração, de modo que o poder de controle ficou limitado à nomeação, à fiscalização e à vigilância da atuação dos administradores. Ademais, o poder decisório de administração foi atribuído à própria administração, a função de controle, ao conselho de vigilância e a função deliberativa, à assembleia geral (ou junta de acionistas), o que denota a divisão do poder social em órgãos sociais e a separação entre direção e vigilância (esta função atribuída ao controlador).

O Projeto de Estatuto da Sociedade Anônima Europeia, que foi submetido à Comissão do Conselho em 30.06.1970, o artigo 6, itens 1 a $3^{264}$, traz uma definição geral

263 "El capital, independientemente de ser un fondo de explotación, aparece como una cifra permanente de contabilidad o número abstracto, signador de las aportaciones de los socios, aportaciones que estos siempre ostentan." (ESCOLAR, Rafael Perez. La Sociedad Anónima Europea. Madrid: Montecorvo, 1972, p. 120) Tradução livre: "O capital, independentemente de ser um fundo de exploração, aparece como uma cifra permanente de contabilidade ou número abstrato, indicador das contribuições dos sócios, contribuições que estes sempre ostentam."

264 “Article 6

1. For the purposes of this Statute, a dependent undertaking is one which is legally autonomous and on which undertaking (hereinafter referred to as the 'controlling company') is able, directly or indirectly, to exercise a controlling influence, one of the wo being an S.E.

2. An undertaking shall in any event be considered depedent on another when that other has the power, in relation to the first;

a) to control more than half the votes attached to the whole of the issued share capital;

b) to appoint more than half of its board of management or of its supervisory body;

c) to exert, pursuant to contracts, a decisive influence its management. 
de poder de controle, segundo a qual uma companhia será considerada como sendo controladora, quando tiver a possibilidade de exercer uma influência dominante direta ou indiretamente sobre outra companhia, não importando, para tanto, a base e os meios pelos quais é exercida a influência dominante, tampouco é exigido o seu exercício efetivo pelo controlador.

Assim, desde já, é possível constatar que o mencionado Projeto define controle com base na possibilidade de exercício da influência dominante que o controlador tem em relação a uma companhia, não sendo exigido o efetivo exercício desta influência dominante para que o controle seja caracterizado, como apontou Rafael Perez Escolar:

\begin{abstract}
"Basta que a empresa dominante tenha a possibilidade de exercer sua influência para que exista a dependência. Pouco importa a base e os meios de exercício desta possibilidade. Somente conta o resultado. Tampouco é preciso que esta influência se exerça efetivamente. Ao contrário, quando uma empresa tem de qualquer forma, direta ou indiretamente, uma influência decisiva e prolongada sobre a gestão da outra, deverá admitir-se que existe dependência." (tradução livre) $)^{265}$
\end{abstract}

Além da disposição contida no item 1 do artigo 6 , o seu item 2 prevê a presunção absoluta de detenção do poder de controle, sempre que o controlador $(\boldsymbol{a})$ detiver mais da metade dos votos conferidos ao total de ações emitidas pela companhia, $(\boldsymbol{b})$ detiver o poder de eleger mais da metade dos membros da administração, seja em razão da participação no capital detida, seja em virtude da existência de acordos neste sentido ou,

A controlling influence shall be presumed to exist where one undertaking has a majority in the capital of another." (Tradução livre: "Artigo 6 1. Para os fins deste Estatuto, uma empresa dependente é aquela que é legalmente autônoma e em cuja dependência (aqui referida como 'companhia controladora') é capaz, direta ou indiretamente, de exercer uma influência controladora, uma das duas sendo uma S.E. 2. Uma dependente deve de qualquer modo ser considerada dependente de outra quando aquela outra tiver o poder, em relação à primeira: a) De controlar mais da metade dos votos ligados ao total do capital social; b) Indicar mais da metade dos componentes da administração ou de seu órgão supervisor ;c) Exercer, em relação a contratos, uma influência decisiva sobre a administração. 3. Uma influência controladora deve ter sua existência presumida quando um dependente detiver a maioria do capital na outra.") (In: SCHMITTHOFF, Clive M. European CompanyLaw Texts. Nova Iorque: Matthew Bender, 1974, p. 177 - 178)

265 "Basta con que la empresa dominante tenga la posibilidad de ejercer su influencia para que exista dependecia. Poco importan la base y los medios de ejercicio de esta posibilidad. Unicamente cuenta el resultado. Tampoco es preciso que esta influencia se ejerza efectivamente. Por el contrario, cuando uma empresa tiene de cualquier forma, directa o indirectamente, una influencia decisiva y prolongada sobre la gestión de otra, deberá admitirse que existe dependencia." (ESCOLAR, Rafael Perez. La Sociedad Anónima Europea. Madrid: Montecorvo, 1972, p. 165) 
ainda, (c) exercer uma influência decisiva preponderante sobre a administração em razão de contratos celebrados.

Já o item 3 do artigo 6 indica uma hipótese de presunção relativa de detenção do poder de controle, isto porque tal presunção decorre da detenção de uma participação majoritária no capital social, sem, contudo, que seja provida com o direito de voto, razão pela qual se admite prova em contrário.

Com efeito, segundo Rafael Perez Escobar, “uma participação majoritária não conduz necessariamente à dependência. Assim ocorrerá, por exemplo, quando uma S.E. detenha ações preferenciais sem direito de voto em uma sociedade de direito nacional. ${ }^{266}$ (tradução livre)

Depois de apresentado, o Projeto sofreu modificações em 1975 e, finalmente, no Jornal Oficial das Comunidades Europeias de $10.11 .2001^{267}$, foi publicado o Regulamento CE n. ${ }^{\circ}$ 2.157/2001 do Conselho, de 09.10.2001, que trata do estatuto da sociedade anônima europeia. Mas, como afirmando no Considerando $9^{268}$, desde a apresentação do Projeto em 1970, os direitos nacionais passaram a efetivar uma aproximação ao direito comunitário.

Dessa forma, em relação ao poder de controle, o Regulamento expressamente remete ao direito nacional da empresa controlada, entendendo não ser necessária uma regulamentação específica quanto ao tema no âmbito do Direito

\footnotetext{
266 "Una participación mayoritaria no conduce necesariamente a la dependecia. Así ocurrirá, por ejemplo, cuando una S.E. detenga acciones privilegiadas sin derecho a voto en una sociedad de derecho nacional." (ESCOLAR, Rafael Perez. La Sociedad Anónima Europea. Madrid: Montecorvo, 1972, p. 166)

${ }^{267}$ Disponível em < http://eur-

lex.europa.eu/LexUriServ/LexUriServ.do?uri=OJ:L:2001:294:0001:0021:FR:PDF>. Último acesso em 16.03.2014.

268 “(9) Depuis que la Commission a présenté, en 1970, une proposition, modifiée en 1975, de règlement portant un statut des sociétés anonymes européennes, les travaux portant sur le rapprochement du droit national des sociétés ont notablement progressé, de sorte que, dans des domaines où le fonctionnement d'une SE n'exige pas de règles communautaires uniformes, il peut être renvoyé à la législation régissant les sociétés anonymes de l'État membre du siège statutaire de la SE." (Tradução livre: “(9) Desde a apresentação pela Comissão, em 1970, da proposta de regulamento relativo ao estatuto das sociedades anónimas europeias, alterada em 1975, os trabalhos de aproximação do direito nacional das sociedades progrediram de forma notável, de tal modo que, no caso da SE, é possível remeter para a legislação das sociedades anónimas do Estado-Membro da sede da SE, nos domínios em que o funcionamento desta não exija regras comunitárias uniformes.") (Disponível em < http://eurlex.europa.eu/LexUriServ/LexUriServ.do?uri=OJ:L:2001:294:0001:0021:FR:PDF>. Acesso em 16.03.2014)
} 
Comunitário Europeu, conforme dispõem os Consideranda 15 e $16^{269}$ do Regulamento CE n. ${ }^{\circ} 2.157 / 2001$ do Conselho.

Não obstante, a 7. ${ }^{a}$ Diretiva do Conselho (83/349/CEE), de 13.06.1983, publicada no Jornal Oficial das Comunidades Europeias de $18.07 .1983^{270}$, que complementou a 4. a Diretiva do Conselho (78/660/CEE) ${ }^{271}$, dispôs expressamente acerca do poder de controle nas sociedades europeias, especialmente para determinar as condições de consolidação das demonstrações financeiras anuais das sociedades empresárias.

Para efeitos de consolidação e conforme o segundo considerando, a 7. ${ }^{\mathrm{a}}$ Diretiva pretendeu permitir que também fosse considerado não só o poder de controle majoritário, mas também o poder de controle constituído com base em contratos e o efetivo exercício do poder de controle minoritário, além dos casos de grupos de empresas que se encontram em situação de igualdade. ${ }^{272}$ Dessa maneira, a mencionada Diretiva trouxe indicações da caracterização do poder de controle no artigo 1. .

269 “(15) En vertu des règles et des principes généraux du droit international privé, lorsqu'une entreprise contrôle une autre entreprise relevant d'un ordre juridique différent, ses droits et obligations en matière de protection des actionnaires minoritaires et des tiers sont régis par le droit dont relève l'entreprise contrôlée, sans préjudice des obligations auxquelles l'entreprise qui exerce le contrôle est soumise en vertu des dispositions du droit dont elle relève, par exemple en matière d'établissement de comptes consolidés.

(16) Sans préjudice des conséquences de toute coordination ultérieure du droit des États membres, une réglementation spécifique pour la SE n'est actuellement pas requise dans ce domaine. Il convient dès lors que les règles et principes généraux du droit international privé s'appliquent tant dans le cas où la SE exerce le contrôle que dans le cas où la SE est la société contrôlée." (Tradução livre: “(15) Por força das regras e princípios gerais de Direito Internacional Privado, quando uma empresa controla outra sujeita a uma ordem jurídica diferente, os seus direitos e obrigações em matéria de proteção dos acionistas minoritários e de terceiros regulam-se pelo direito a que está sujeita a empresa controlada, sem prejuízo das obrigações a que está submetida a empresa que exerce o controle por força das disposições do direito ao qual está sujeita, por exemplo, em matéria de elaboração de contas consolidadas.

(16) Sem prejuízo das consequências de uma posterior coordenação do direito dos Estados-Membros, não é atualmente necessária uma regulamentação específica para a SE neste domínio. Devem-se, portanto, aplicar as regras e princípios gerais, tanto nos casos em que a SE exerce o controle como nos casos em que a SE é a sociedade controlada.") (Disponível em http://eurlex.europa.eu/LexUriServ/LexUriServ.do?uri=OJ:L:2001:294:0001:0021:FR:PDF>. Acesso em 16.03.2014) $270 \quad$ Disponível em $<$ http://eurlex.europa.eu/LexUriServ/LexUriServ.do?uri=CONSLEG:1983L0349:20070101:FR:PDF>. Último acesso em 16.03.2014.

${ }^{271}$ Disponível em < http://eur-lex.europa.eu/LexUriServ/LexUriServ.do?uri=celex:3197810660:PT:HTML>. Acesso em 16.03.2014.

272 "Considérant que, pour déterminer les conditions de consolidation, il faut avoir égard non seulement aux cas où le pouvoir de contrôle est fondé sur une majorité des droits de vote mais aussi aux cas où il est fondé sur des accords, là où ceux-ci sont admis; qu'il faut en outre permettre aux États membres où cela se produit de couvrir le cas où, dans certaines circonstances, l'exercice effectif du contrôle a été constaté sur la base d'une participation minoritaire; qu'il faut enfin permettre aux États membres de couvrir le cas des ensembles d'entreprises qui se trouvent entre elles sur un pied d'égalité;" (Tradução livre: "Considerando que, para 
determinar as condições de consolidação, é preciso considerar não apenas os casos em que o poder de controle está fundado em uma maioria de direito de voto, mas também os casos nos quais ele está fundado em acordos, aonde eles são admitidos; que é necessário por outro lado permitir aos Estados membros nos quais surge a necessidade de abarcar os casos em que, dentro de certas circunstâncias, o exercício efetivo do controle é constatado com base em uma participação minoritária; que é preciso enfim permitir aos Estados membros de abranger os casos de grupo de empresas que apresentam uma posição de igualdade ;") (Disponível em <http://eurlex.europa.eu/LexUriServ/LexUriServ.do?uri=CONSLEG:1983L0349:20070101:FR:PDF>. Acesso em 16.03.2014)

273 "Article premier

1. Les États membres imposent à toute entreprise qui relève de leur droit national l'obligation d'établir des comptes consolidés et un rapport consolidé de gestion si cette entreprise (entreprise mère):

a) a la majorité des droits de vote des actionnaires ou associés d'une entreprise (entreprise filiale),

ou

b) a le droit de nommer ou de révoquer la majorité des membres de l'organe d'administration, de direction ou de surveillance d'une entreprise (entreprise filiale), et est en même temps actionnaire ou associé de cette entreprise,

ou

c) a le droit d'exercer une influence dominante sur une entreprise (entreprise filiale) dont elle est actionnaire ou associé, en vertu d'un contrat conclu avec celle-ci ou en vertu d'une clause des statuts de celle-ci, lorsque le droit dont relève cette entreprise filiale permet qu'elle soit soumise à de tels contrats ou clauses statutaires; les États membres peuvent ne pas prescrire que l'entreprise mère soit actionnaire ou associé de l'entreprise filiale. Les États membres dont le droit ne prévoit pas un tel contrat ou une telle clause statutaire ne sont pas tenus d'appliquer cette disposition,

ou

d) est actionnaire ou associé d'une entreprise et

aa) que la majorité des membres de l'organe d'administration, de direction ou de surveillance de cette entreprise (entreprise filiale), en fonction durant l'exercice ainsi que l'exercice antérieur et jusqu'à l'établissement des comptes consolidés, ont été nommés par l'effet du seul exercice de ses droits de vote ou

bb) qu'elle contrôle seule, en vertu d'un accord conclu avec d'autres actionnaires ou associés de cette entreprise (entreprise filiale), la majorité des droits de vote des actionnaires ou associés de celle-ci. Les États membres peuvent prendre des dispositions plus détaillées relatives à la forme et au contenu de cet accord.

Les États membres imposent au moins la réglementation figurant au point bb).

Ils peuvent subordonner l'application du point aa) au fait que le pourcentage de la participation soit égal à $20 \%$ ou plus des droits de vote des actionnaires ou associés.

Toutefois, le point aa) ne s'applique pas si une autre entreprise a, à l'égard de cette entreprise filiale, des droits visés aux points a), b) ou c)." (Tradução livre: "Artigo primeiro. 1. Os Estados membros obrigarão toda empresa que se submetem a seu direito nacional a obrigação de estabelecer contas consolidadas e um relatório consolidado de gestão se esta empresa (empresa controladora): a) possuir a maioria dos direitos de voto dos acionistas ou associados de uma empresa (empresa controlada), ou b) possuir o direito de nomear ou de destituir a maioria dos membros do órgão de administração, de direção ou de vigilância de uma empresa (empresa controlada), e ser ao mesmo tempo acionista ou associado desta empresa, ou c) tiver o direito de exercer uma influência dominante sobre uma empresa (empresa controlada) que é acionista ou associada, em virtude de um contrato celebrado com aquela ou em virtude de uma cláusula do estatuto daquela, quando o direito a que se sujeita esta empresa controlada permite que ela seja submetida a tais contratos ou cláusulas estatutárias; os Estados membros podem apenas prescrever que a empresa controladora seja acionista ou associada da empresa controlada. Os Estados membros cujo direito não preveja tais contratos ou cláusulas estatutárias não terão de aplicar esta disposição, ou d) for acionista ou associada de uma empresa e aa) que a maioria dos membros do órgão de administração, de direção ou de vigilância desta empresa (empresa controlada), em exercício durante o exercício ainda que anterior e até o estabelecimento das contas consolidadas, foram nomeados por consequência do exercício dos direitos de voto ou bb) que controla sozinha, em razão de um acordo celebrado com outros acionistas ou associados desta empresa (empresa controlada), a maioria dos direitos de voto dos acionistas ou associados daquela 
incidência da exigência de demonstrações financeiras consolidadas, o acionista que: (a) detiver a maioria dos votos de uma companhia; ou (b) tiver direito de nomear e/ou destituir a maioria dos membros do órgão de administração, de direção ou de vigilância da companhia e simultaneamente é acionista; ou (c) possuir o direito de exercer influência dominante sobre uma companhia da qual é acionista, em virtude de acordo de acionistas ou de cláusula estatutária; ou (d) além de ser titular dos direitos de acionista de uma companhia, nomear a maioria dos membros dos órgãos de administração, de direção ou de vigilância durante certo exercício, em razão do mero exercício de seu direito de voto igual ou superior a $20 \%$ das ações com direito de voto (salvo se houver outro acionista que possua os direitos indicados nos itens $(\boldsymbol{a}),(\boldsymbol{b})$ ou (c) retro mencionados), ou, ainda, controlar individualmente a companhia, em razão de acordo de acionistas, e detiver a maioria dos votos.

Já a Diretiva 88/627/CEE do Conselho, de 12.12.1988 ${ }^{274}$, publicada no Jornal Oficial das Comunidades Europeias de 17.12.1988, que regulamentou as informações a serem publicadas quando da aquisição ou da alienação, direta ou por interposta pessoa de uma participação importante em companhia com ações cotadas em bolsa de valores, que cause uma modificação na composição societária em relação à detenção de ações com direito de voto, apresentou em seu art. $8 .^{.275}$ a definição de empresa

empresa. Os Estados membros podem elaborar disposições mais detalhadas em relação à forma e ao conteúdo deste acordo. Os Estados membros imporão por meio da regulamentação caracterizada no item bb). Eles podem subordinar a aplicação do item aa) ao fato da porcentagem de participação ser igual a $20 \%$ ou mais dos direitos de voto dos acionistas ou associados. Entretanto, o item aa) não se aplica se uma outra empresa tiver, em relação a esta empresa controlada, os direitos previstos nos itens a), b) ou c).”) (Disponível em < http://eurlex.europa.eu/LexUriServ/LexUriServ.do?uri=CONSLEG:1983L0349:20070101:FR:PDF>. Último acesso em 16.03.2014.)

274

Disponível

em

$<$ http://eur-

lex.europa.eu/LexUriServ/LexUriServ.do?uri=CELEX:31988L0627:FR:HTML>. Último acesso em 23.03.2014.

275 "Article 8

1. Aux fins de la présente directive, on entend par " entreprise contrôlée » toute entreprise dans laquelle une personne physique ou une entité juridique:

a) a la majorité des droits de vote des actionnaires ou associés; ou

b) a le droit de nommer ou de révoquer la majorité des membres de l'organe d'administration, de direction ou de surveillance et est en même temps actionnaire ou associé de cette entreprise; ou

c) est actionnaire ou associé et contrôle seule, en vertu d'un accord conclu avec d'autres actionnaires ou associés de cette entreprise, la majorité des droits de vote des actionnaires ou associés de celle-ci.

2. Pour l'application du paragraphe 1 , les droits de vote, de nomination ou de révocation de l'entreprise mère doivent être majorés des droits de toute autre entreprise contrôlée, ainsi que de ceux de toute personne ou entité agissant en son nom mais pour le compte de l'entreprise mère ou de toute autre entreprise contrôlée." (Tradução livre: "Artigo 8. ${ }^{\circ}$. 1. Para os efeitos da presente diretiva, entende-se por "empresa controlada» qualquer empresa em que uma pessoa física ou uma entidade jurídica: 
controlada, da qual, combinando com as disposições constantes dos arts. $1 .^{\circ}$, item $1^{276}$, $2 .^{\text {o277 }} 4^{\mathrm{o}}$, item $1^{278}$ e $7 .^{\text {.279 }}$, é possível extrair a definição de empresa controladora.

a) Tenha a maioria dos direitos de voto dos acionistas ou sócios; ou

b) Tenha o direito de nomear ou de destituir a maioria dos membros do orgão de administração, de direção ou de fiscalização e seja simultaneamente acionista ou sócio dessa empresa; ou

c) Seja acionista ou sócio e que, por força de um acordo celebrado com outros acionistas ou sócios dessa empresa, tenha o controle exclusivo da maioria dos direitos de voto dos seus acionistas ou sócios.

2. Para efeitos da aplicação do $n^{\circ} 1$, os direitos de voto, de nomeação ou de destituição da empresa-mãe devem ser acrescidos dos direitos de qualquer outra empresa controlada, bem como dos de qualquer pessoa ou entidade que atue em seu nome mas por conta da empresa-mãe ou de qualquer outra empresa controlada.") (Disponível em <http://eurlex.europa.eu/LexUriServ/LexUriServ.do?uri=CELEX:31988L0627:FR:HTML>. Acesso em 23.03.2014)

276 "Article premier. 1. Les États membres soumettent à la présente directive les personnes physiques et les entités juridiques de droit public ou privé qui acquièrent ou cèdent, directement ou par personne interposée, une participation répondant aux critères définis à l'article 4 paragraphe 1 et entraînant une modification dans la détention des droits de vote d'une société qui relève de leur législation et dont les actions sont admises à la cote officielle d'une ou de plusieurs bourses de valeurs situées ou opérant dans un ou plusieurs États membres." (Tradução livre: "Artigo $1^{\circ}$. 1. Os Estados-membros submeterão à presente diretiva as pessoas singulares e as entidades jurídicas de direito público ou privado que adquiram ou alienem, diretamente ou por interposta pessoa, uma participação que corresponda aos critérios definidos no $n^{o} 1$ do artigo $4^{o}$ e que implique uma modificação na detenção dos direitos de voto de uma sociedade sujeita à sua legislação cujas ações tenham sido admitidas à cotação oficial de uma ou de várias bolsas de valores situadas ou a funcionar num ou em vários Estados-membros.") (Disponível em <http://eurlex.europa.eu/LexUriServ/LexUriServ.do?uri=CELEX:31988L0627:FR:HTML>. Acesso em 23.03.2014)

277 "Article 2. Aux fins de la présente directive, on entend par "acquisition d'une participation" non seulement l'achat d'une participation, mais également toute autre obtention d'une participation, quel que soit son titre ou le procédé utilisé, y compris l'obtention d'une participation en vertu d'un des cas visés à l'article 7." (Tradução livre: "Artigo $2^{\circ}$. Para os efeitos da presente diretiva, entende-se por "aquisição de uma participação » tanto a compra da participação como qualquer outra obtenção de uma participação, seja qual for a sua denominação ou o processo utilizado, incluindo a obtenção de uma participação por força de uma das situações referidas no artigo $7^{\circ}$.") (Disponível em <http://eurlex.europa.eu/LexUriServ/LexUriServ.do?uri=CELEX:31988L0627:FR:HTML>. Acesso em 23.03.2014)

278 “Article 4. 1. Lorsqu'une personne physique ou une entité juridique visée à l'article ler paragraphe 1 acquiert ou cède une participation dans une société visée à l'article ler paragraphe 1 et que, par suite de cette acquisition ou cession, le pourcentage des droits de vote qu'elle détient atteint ou dépasse les seuils de $10 \%, 20 \%, 1 / 3,50 \%$ et $2 / 3$ ou descend en dessous de ces seuils, elle doit informer la société et simultanément la ou les autorités compétentes visées à l'article 13, dans un délai de sept jours civils, du pourcentage des droits de vote qu'elle détient après cette acquisition ou cession. Les États membres peuvent ne pas appliquer:

- les seuils de $20 \%$ et de 1 / 3 lorsqu'ils appliquent un seul seuil de $25 \%$,

- le seuil de 2 / 3 lorsqu'ils appliquent un seuil de 75 \%." (Tradução livre: "Artigo 4. 1. Quando uma pessoa singular ou uma entidade jurídica referida no $n^{o} 1$ do artigo $1^{\circ}$ adquirir ou alienar uma participação numa sociedade referida no $n^{o} 1$ do artigo $1^{\circ}$ e sempre que, na sequência de tal aquisição ou alienação, a porcentagem dos direitos de voto que detém atinja ou ultrapasse os limiares de 10\%, 20 \%, 1/3, $50 \%$ e 2 / 3, ou desça abaixo de tais limiares, essa pessoa ou essa entidade deve informar a sociedade e, simultaneamente, a ou as autoridades competentes referidas no artigo $13^{\circ}$, no prazo de sete dias úteis, da percentagem dos direitos de voto que passe a deter depois de tal aquisição ou alienação. Os Estadosmembros podem não aplicar:

- os limiares de $20 \%$ e de 1/3, quando aplicarem um único limiar de $25 \%$,

- o limiar de 2 / 3, quando aplicarem um único limiar de $75 \%$.") (Disponível em <http://eurlex.europa.eu/LexUriServ/LexUriServ.do?uri=CELEX:31988L0627:FR:HTML>. Acesso em 23.03.2014)

279 "Article 7. Pour apprécier si une personne physique ou une entité juridique visée à l'article ler paragraphe 1 est tenue de faire la déclaration prévue à l'article 4 paragraphe 1 et à l'article 5 , il convient d'assimiler aux droits de vote qu'elle détient: 
Com efeito, nos termos do art. $8 .^{\circ}$ da Diretiva 8/627/CEE do Conselho, será considerado acionista controlador a pessoa física ou entidade jurídica que (a) tenha a maioria dos votos ou, (b) sendo acionista, tenha o direito de nomear e destituir a maioria dos membros do órgão de administração, de direção ou de fiscalização ou, (c) sendo

- les droits de vote détenus en leur nom propre par d'autres personnes ou entités, pour le compte de cette personne ou entité,

- les droits de vote détenus par les entreprises que contrôle cette personne ou entité,

- les droits de vote détenus par un tiers avec qui cette personne ou entité a conclu un accord écrit qui les oblige à adopter, par un exercice concerté des droits de vote dont ils détiennent, une politique commune durable vis-à-vis de la gestion de la société en question,

- les droits de vote détenus par un tiers en vertu d'un accord écrit conclu avec cette personne ou entité ou avec l'une des entreprises que cette personne ou entité contrôle et qui prévoit un transfert provisoire et rémunéré de ces droits de vote,

- les droits de vote attachés aux actions détenues par cette personne ou entité qui sont déposées en garantie, sauf quand le dépositaire détient des droits de vote et déclare son intention de les exercer; dans ce cas, ils sont assimilés aux droits de vote que détient ce dernier,

- les droits de vote attachés aux actions dont cette personne ou entité a l'usufruit,

- les droits de vote que cette personne ou entité ou l'une des autres personnes ou entités mentionnées aux tirets précédents peut acquérir, à seule initiative, en vertu d'un accord formel; dans ce cas, les informations prévues à l'article 4 paragraphe 1 sont faites à la date de l'accord,

- les droits de vote qui sont attachés aux actions déposées auprès de cette personne ou entité et que celle-ci peut exercer comme elle l'entend en l'absence d'instructions spécifiques des détenteurs.

Par dérogation à l'article 4 paragraphe 1, lorsqu'une personne ou entité peut exercer dans une société des droits de vote visés au dernier tiret de l'alinéa précédent et que l'ensemble de ces droits de vote en combinaison avec les autres droits de vote que cette personne ou entité détient dans cette société atteint ou dépasse l'un des seuils prévus à l'article 4 paragraphe 1, les États membres peuvent prévoir que ladite personne ou entité est seulement tenue d'informer la société en question dans un délai de vingt et un jours civils avant l'assemblée générale de cette dernière." (Tradução livre: "Artigo $7^{\circ}$. Para determinar se uma pessoa singular ou uma entidade jurídica referida no $n^{o} 1$ do artigo $1^{o}$ é obrigada a fazer a declaração prevista no $n^{o} 1$ do artigo $4^{\circ}$ e no artigo $5^{\circ}$, é conveniente equiparar aos direitos de voto que detenha:

- os direitos de voto detidos em seu próprio nome por outras pessoas ou entidades por conta dessa pessoa ou entidade,

- os direitos de voto detidos pelas empresas controladas por essa pessoa ou entidade,

- os direitos de voto detidos por um terceiro com o qual essa pessoa ou entidade tenha celebrado um acordo escrito que os obriga a adotar, através de um exercício concertado dos direitos de voto que detêm, uma política comum em relação à gestão da sociedade em causa,

- os direitos de voto detidos por um terceiro por força de um acordo escrito celebrado com essa pessoa ou entidade ou com uma das empresas controladas por essa pessoa ou entidade em que se preveja uma transferência provisória e remunerada desses direitos de voto,

- os direitos de voto associados a ações detidas como caução por essa pessoa ou entidade, exceto quando o depositário detenha direitos de voto e declare a sua intenção de os exercer; neste caso, os direitos de voto serão assimilados aos direitos de voto do depositário,

- os direitos de voto associados às ações de que essa pessoa ou entidade tenha o usufruto,

- os direitos de voto que essa pessoa ou entidade ou uma das outras pessoas ou entidades referidas nos travessões anteriores possam adquirir, por sua exclusiva iniciativa, por força de um acordo formal; neste caso, as informações previstas no $n^{\circ} 1$ do artigo $4^{\circ}$ devem ser prestadas na data da celebração do acordo,

- os direitos de voto associados às ações depositadas junto dessa pessoa ou entidade e que ela possa exercer como entender na ausência de instruções específicas dos respectivos detentores.

Quando uma pessoa ou entidade possa exercer numa sociedade os direitos de voto referidos no último travessão do parágrafo anterior e o conjunto desses direitos de voto, juntamente com os outros direitos de voto que essa pessoa ou entidade detenha nessa sociedade, atinja ou ultrapasse um dos limiares previstos no $n^{o} 1$ do artigo $4^{o}$, os Estados-membros podem prever, em derrogação a esse mesmo $n^{\circ} 1$ do artigo $4^{o}$, que a referida pessoa ou entidade só será obrigada a informar a sociedade em questão no prazo de vinte e um dias antes da assembleia geral dessa mesma sociedade.") (Disponível em <http://eurlex.europa.eu/LexUriServ/LexUriServ.do?uri=CELEX:31988L0627:FR:HTML〉. Último acesso em 23.03.2014) 
acionista, tenha o controle exclusivo da maioria dos votos dos acionistas em razão da celebração de acordo de acionistas.

Decorre indiretamente da previsão disposta no artigo $4 .^{\circ}$ da Diretiva, que a detenção do poder de controle poderá ser concretizada se, com a aquisição ou, ainda, com a obtenção por qualquer meio, da participação em uma companhia, atinja ou ultrapasse a titularidade de $10 \%$ (dez por cento) de ações com direito de voto, caso em que já se pode considerar que o adquirente desta participação tenha atingido uma participação relevante e, por isso, passível de ser informada ao mercado de valores mobiliários, desde que tal aquisição ou alienação implique em mudança na composição societária da companhia em relação às ações com direito de voto.

Observe-se, ainda, que o Projeto de Estatuto de Sociedade Anônima Europeia dispunha, em seu artigo $82^{280}$, a obrigação de comunicação de aquisição de ações, sempre que o acionista passasse a deter, direta ou por interposta pessoa, individualmente ou em conjunto com o cônjuge e seus filhos, mais de $10 \%$ do capital da sociedade, caso em que já poderia ser considerado acionista principal.

Assim, dos dispositivos de Diretivas da Comunidade Europeia, que foram mencionados, percebe-se que o acionista controlador de uma companhia é definido primordialmente com base na influência dominante que pode exercer sobre toda a companhia por intermédio do exercício do direito de voto, cuja concentração a partir de $10 \%$ (dez por cento) das ações votantes já permite a assunção do poder de controle da companhia, justamente por se considerar, no âmbito do Direito Comunitário Europeu, que uma participação de $10 \%$ (dez por cento) ou mais já é uma participação relevante e capaz de mudar a estrutura de voto da companhia e, por isso, sujeita à comunicação prevista na Diretiva 88/267/CEE.

\footnotetext{
280 “Article 82. (...) Subject to Article 47, paragraph 5, the same obligation shall apply to any person who holds, directly or through an intermediary, solely or jointly with his spouse or infant children, more than $10 \%$ of the capital of the company." (Tradução livre: "Artigo 82. (...) Sujeito ao Artigo 47, parágrafo 5, a mesma obrigação será aplicada a qualquer pessoa que detenha, diretamente ou por um intermediário, individualmente ou conjuntamente com seu cônjuge ou filho menor de idade, mais que $10 \%$ do capital da companhia.") (In: SCHMITTHOFF, Clive M. European CompanyLaw Texts. Nova Iorque: Matthew Bender, 1974, p. 205)
} 
Ademais, não se exige do acionista controlador o efetivo exercício do poder de controle, bastando a detenção da mera possibilidade de exercê-lo. O exercício do poder de controle implica (a) na detenção da maioria de votos ou $(\boldsymbol{b})$ na detenção do direito de nomear e destituir os membros dos órgãos de administração, de direção e de fiscalização, caso em que o acionista controlador deve deter pelo menos $20 \%$ (vinte por cento) das ações com direito a voto ou (c) no direito de exercer influência dominante em virtude da celebração de acordo de acionistas ou de cláusula estatutária ou, ainda, (d) na detenção individual do controle da companhia aliado com a detenção da maioria dos votos em razão da celebração de acordo de acionistas. 


\subsection{O DIREITO FRANCÊS}

Segundo uma pesquisa realizada pelo Institut National de la Statistique et des Études Économiques ${ }^{281}$, em 01.05.2001, em um universo de 1.230.032 (um milhão, duzentos e trinta mil e trinta e duas) sociedades existentes, de todos os tipos societários utilizados na França, a sociedade anônima é a terceira espécie mais usada, representando $12,8 \%$ (doze inteiros e oito décimos por cento) de todos os tipos societários existentes.

Não obstante sua pequena utilização se comparada com o uso da société à responsabilité limitée, que remonta a $66,75 \%$ (sessenta e seis inteiros e setenta e cinco centésimos por cento) das empresas existentes em 01.05.2001, a sociedade por ações na França é vista pela doutrina como o instrumento jurídico principal de concentração de capital e do poder econômico.

Assim, sendo considerado um instrumento jurídico adaptado à evolução estrutural econômica, a sociedade por ações permite a concentração de capital por meio do uso de valores mobiliários visando à captação da poupança pública, bem como pelo reinvestimento de parte dos dividendos não distribuídos, com o intuito de "financiar o crescimento da empresa ou as operações pelas quais ela pode dominar as outras sociedades" 282 (tradução livre), do que resulta sua importância e, ainda, explica sua presença e utilização em todos os países, independentemente do sistema econômico e político dos países $^{283}$.

O Código Comercial francês ${ }^{284}$, no Livro II, que cuida das sociedades comerciais e dos grupos de interesse econômico, destina o Capítulo V do Título II (Das

\footnotetext{
${ }^{281}$ In: COZIAN, Maurice; VIANDIER, Alain ; DEBOISSY, Florence. Droit des Sociétés. 14. ${ }^{\text {a }}$ edição. Paris: Litec, 2001, p. 2 - 3.

282 “(...) ils sont mis en réserve afin de financer la croisssance de l'enterprise ou les opérations par lesquelles elle peut assujetir d'autres sociétés."(CHAMPAUD, Claude. Le Pouvoir de Concentration de la Société par Actions. Paris: Sirey, 1962, p. 10)

${ }^{283}$ Vide CHAMPAUD, Claude. Le Pouvoir de Concentration de la Société par Actions. Paris: Sirey, 1962, p. $10-11$.

284 Versão em vigor em 30.03.2014 disponível em: <http://www.legifrance.gouv.fr/affichCode.do?cidTexte=LEGITEXT000005634379\&dateTexte=20140330> . Acesso em 30.03.2014.
} 
Disposições Particulares das Diversas Sociedades Comerciais) para o tratamento das sociedades anônimas, especialmente nos artigos L225-1 a L225-270.

Tais artigos cuidam de toda a regulamentação da sociedade por ações, sem, contudo, mencionar o conceito de poder de controle, tampouco de acionista controlador, tal como podemos observar no Direito Brasileiro, especialmente no art. 116 da Lei n. ${ }^{\circ}$ 6.404/76. Todavia, como ocorre no Direito Comunitário Europeu, o Direito Francês privilegiou a definição legal de controle no âmbito dos grupos societários, denotando certa sincronia com as normas do Direito Comunitário Europeu.

Assim, somente no Título III (Das Disposições Comuns às Sociedades Comerciais), encontramos a referência ao poder de controle, especificamente no Capítulo III, que trata das filiais, das participações e das sociedades controladas.

Com efeito, a Seção 1 (Definições), que traz definições a serem utilizadas em todo o Capítulo III (quais sejam, as definições de filial e de participação) ou, ainda, em algumas de suas Seções (como ocorre com a definição de sociedade controladora), nos artigos L233-1, L233-2 e L233-3 do Código Comercial Francês, apresenta uma diferenciação preliminar entre sociedade filial, participação em sociedade e sociedade controladora respectivamente.

Segundo o artigo L233-1 ${ }^{285}$, sempre que uma sociedade tiver a participação de outra em seu capital social e desde que esta participação seja superior à metade, a primeira será considerada como sendo filial da segunda sociedade. Já o artigo L233-2 286 indica que será considerada mera participação de uma sociedade em outra quando a

285 "Article L233-1

Lorsqu'une société possède plus de la moitié du capital d'une autre société, la seconde est considérée, pour l'application du présent chapitre, comme filiale de la première." (Tradução livre: "Quando uma sociedade possuir mais da metade do capital de outra sociedade, a segunda é considerada, para a aplicação do presente capítulo, como filial da primeira.") <http://www.legifrance.gouv.fr/affichCode.do;jsessionid=58086CD4BD27723D00CCA8460E177646.tpdjo1 $4 \mathrm{v} \_1$ ? cidTexte $=$ LEGITEXT000005634379\&dateTexte=20140330 > . Acesso em 30.03.2014

286 "Article L233-2

Lorsqu'une société possède dans une autre société une fraction du capital comprise entre 10 et $50 \%$, la première est considérée, pour l'application du présent chapitre, comme ayant une participation dans la seconde." (Tradução livre: "Quando uma sociedade possuir em outra sociedade uma fração do capital compreendida entre 10 e 50\%, a primeira é considerada, para a aplicação do presente capítulo, como detentora de uma participação na segunda.") (Disponível em <http://www.legifrance.gouv.fr/affichCode.do;jsessionid=58086CD4BD27723D00CCA8460E177646.tpdjo1 4v_1 ?cidTexte=LEGITEXT000005634379\&dateTexte=20140330>. Acesso em 30.03.2014. 
primeira detiver uma fração do capital social da segunda, que deverá estar compreendida entre $10 \%$ (dez por cento) e $50 \%$ (cinquenta por cento).

Por fim, o artigo L233-3 $3^{287}$ do Código Comercial da França, conforme redação dada pela Lei n. ${ }^{o}$ 2005-842, de 26.07.2005, indica o conceito de sociedade controladora para efeitos de aplicação das Seções 2 (Das Notificações e Das Informações) e 4 (Das Participações Recíprocas) do Capítulo III (Das Filiais, Das Participações e das Sociedades Controladas). Segundo esta definição, considera-se como sendo sociedade controladora a sociedade que: (a) detiver uma participação que lhe confere a maioria de votos na assembleia geral; $(\boldsymbol{b})$ detiver apenas a maioria dos votos por meio de acordo de acionistas que não seja contrário aos interesses da sociedade controlada; (c) determinar de fato as decisões assembleares por meio dos votos que detém; $(\boldsymbol{d})$ detiver o poder de nomear ou destituir a maioria dos membros dos órgãos de administração, de direção e de fiscalização da sociedade controlada.

\footnotetext{
287 "Article L233-3
}

I. - Une société est considérée, pour l'application des sections 2 et 4 du présent chapitre, comme en contrôlant une autre :

$1^{\circ}$ Lorsqu'elle détient directement ou indirectement une fraction du capital lui conférant la majorité des droits de vote dans les assemblées générales de cette société;

$2^{\circ}$ Lorsqu'elle dispose seule de la majorité des droits de vote dans cette société en vertu d'un accord conclu avec d'autres associés ou actionnaires et qui n'est pas contraire à l'intérêt de la société ;

$3^{\circ}$ Lorsqu'elle détermine en fait, par les droits de vote dont elle dispose, les décisions dans les assemblées générales de cette société ;

$4^{\circ}$ Lorsqu'elle est associée ou actionnaire de cette société et dispose du pouvoir de nommer ou de révoquer la majorité des membres des organes d'administration, de direction ou de surveillance de cette société.

II. - Elle est présumée exercer ce contrôle lorsqu'elle dispose directement ou indirectement, d'une fraction des droits de vote supérieure à $40 \%$ et qu'aucun autre associé ou actionnaire ne détient directement ou indirectement une fraction supérieure à la sienne.

III. - Pour l'application des mêmes sections du présent chapitre, deux ou plusieurs personnes agissant de concert sont considérées comme en contrôlant conjointement une autre lorsqu'elles déterminent en fait les décisions prises en assemblée générale." (Tradução livre: "Artigo L233-3. I. - Uma sociedade é considerada, para aplicação das seções 2 e 4 do presente capítulo, como controladora de outra: $1^{\circ}$ Quando ela detém diretamente ou indiretamente uma fração do capital que lhe confere a maioria dos direitos de voto nas assembleias gerais daquela sociedade; $2^{\circ}$ Quando ela tiver apenas a maioria dos direitos de voto naquela sociedade em virtude de um acordo celebrado com outros sócios ou acionistas e que não é contrário ao interesse da sociedade; $3^{\circ}$ Quando ela determina de fato, por meio dos direitos de voto que ela dispõe, as decisões nas assembleias gerais daquela sociedade; $4^{\circ}$ Quando ela é sócia ou acionista daquela sociedade e dispõe do poder de nomear ou destituir a maioria dos membros dos órgãos da administração, de direção ou de fiscalização daquela sociedade. II. - Presume-se que ela exerce aquele controle quando ela detém diretamente ou indiretamente, de uma fração dos direitos de voto superior a $40 \%$ e desde que nenhum outro sócio ou acionista detenha diretamente ou indiretamente uma fração superior à dela. III. - Para a aplicação das mesmas seções do presente capítulo, duas ou mais pessoas que agem conjuntamente são consideradas no controle conjunto de outra quando elas determinam de fato as decisões tomadas em assembleia geral.") (Disponível 
Ainda, nos termos do item II, do artigo L233-3, do Código Comercial Francês, presume-se a detenção do poder de controle, sempre que uma sociedade detiver, direta ou indiretamente, uma participação com direito de voto superior a $40 \%$ (quarenta por cento), mas desde que nenhum outro sócio ou acionista detenha, diretamente ou indiretamente, uma participação superior àquela detida pela sociedade.

O item III do artigo L233-3 combinado com o artigo L233-10 288 (com a nova redação dada pela Lei n. ${ }^{\circ}$ 2010-1249, de 22.10.2010) e com o artigo L233-16, item III $^{289}$ (com a redação dada pela Lei n. ${ }^{\circ}$ 2003-706, de 01.08.2003), todos do Código Comercial Francês, definem o exercício do poder de controle conjunto, que é aquele em que há a divisão do exercício do poder de controle entre um número limitado de sócios ou acionistas, o que ocorre quando duas ou mais pessoas celebram um acordo com o fim de adquirir, ceder ou exercer o direto de voto, de modo que os controladores conjuntos determinam as decisões tomadas na assembleia geral com o fim colocar em prática uma política comum na sociedade.

Por fim, o artigo L233-16, item II $^{290}$ (com a nova redação dada pela Lei n. ${ }^{\circ}$ 203-706, de 01.08.2003), acrescenta, ainda, a definição de controle exclusivo, o qual é

288 “Article L233-10
I.-Sont considérées comme agissant de concert les personnes qui ont conclu un accord en vue d'acquérir, de
céder ou d'exercer des droits de vote, pour mettre en cuvre une politique commune vis-à-vis de la société ou
pour obtenir le contrôle de cette société." (Tradução livre: "Artigo L233-10. I. - São considerados como
atuantes conjuntos, as pessoas que celebraram um acordo com o fim de adquirir, ceder ou exercer os
direitos de voto, para colocar em prática uma política comum referente à sociedade ou para obter o controle
daquela
sociedade.”)(Disponível <http://www.legifrance.gouv.fr/affichCode.do;jsessionid=58086CD4BD27723D00CCA8460E177646.tpdjo1 $4 \mathrm{v} \_1$ ?cidTexte=LEGITEXT000005634379\&dateTexte=20140330>. Último acesso em 30.03.2014.

289 "Article L233-16

(...)

III. - Le contrôle conjoint est le partage du contrôle d'une entreprise exploitée en commun par un nombre limité d'associés ou d'actionnaires, de sorte que les décisions résultent de leur accord. " (Tradução livre: "Artigo L233-16. (...) III. - O Controle conjunto é a divisão do controle de uma empresa explorada em comum por um número limitado de sócios ou acionistas, de forma que as decisões resultam do acordo deles.")(Disponível

em <http://www.legifrance.gouv.fr/affichCode.do;jsessionid=58086CD4BD27723D00CCA8460E177646.tpdjo1 $4 \mathrm{v} \_1$ ?cidTexte=LEGITEXT000005634379\&dateTexte=20140330 > . Acesso em 30.03.2014.

290 "Article L233-10

(...)

II. - Le contrôle exclusif par une société résulte :

$1^{\circ}$ Soit de la détention directe ou indirecte de la majorité des droits de vote dans une autre entreprise ;

$2^{\circ}$ Soit de la désignation, pendant deux exercices successifs, de la majorité des membres des organes d'administration, de direction ou de surveillance d'une autre entreprise. La société consolidante est présumée avoir effectué cette désignation lorsqu'elle a disposé au cours de cette période, directement ou 
conceituado como sendo aquele que resulta $(\boldsymbol{a})$ da detenção da maioria dos votos em uma sociedade, (b) da designação da maioria dos membros dos órgãos de administração, de direção ou de fiscalização por dois exercícios consecutivos ou presumivelmente se detiver uma participação com direito de voto superior a $40 \%$ (quarenta por cento), desde que não haja outro sócio ou acionista com participação superior ou $(\boldsymbol{c})$ do exercício de uma influência dominante em razão de contrato ou de cláusulas estatutárias, desde que o direito aplicável admita esta forma de controle.

Assim, feita esta breve referência aos dispositivos do Código Comercial da França que tratam do poder de controle, pode-se concluir que, segundo o Direito Francês, o poder de controle consiste no exercício, exclusivo ou conjunto (que é aquele decorrente da celebração de acordo de acionistas, não contrário aos interesses da companhia, com o fim de adquirir, ceder ou exercer o direito de voto, com a finalidade de colocar em prática política comum da sociedade por ações ou, ainda, de obter o poder de controle), de uma influência dominante e ativa na sociedade, consistente na determinação de fato das decisões tomadas em Assembleia Geral ou na detenção de participação que confere ao acionista a maioria dos votos em Assembleia Geral, bem como no poder de nomear ou destituir a maioria dos membros dos órgãos de administração, de direção ou de fiscalização, por dois exercícios, proporcionado ao acionista controlador o poder de orientar a administração da sociedade.

Segundo a legislação francesa, a detenção do poder de controle é presumida sempre que um acionista detiver uma participação superior a $40 \%$ (quarenta por cento) das ações com direito de voto, desde que não haja outro acionista com participação, direta ou indireta, superior àquela.

indirectement, d'une fraction supérieure à $40 \%$ des droits de vote, et qu'aucun autre associé ou actionnaire ne détenait, directement ou indirectement, une fraction supérieure à la sienne ;

$3^{\circ}$ Soit du droit d'exercer une influence dominante sur une entreprise en vertu d'un contrat ou de clauses statutaires, lorsque le droit applicable le permet." (Tradução livre: "Artigo L233-16. (...) II. - O Controle exclusivo de uma sociedade resulta: $1^{\circ}$ Seja da detenção direta ou indireta da maioria dos direitos de voto em uma outra empresa; $2^{\circ}$ Seja da designação, por dois exercícios sucessivos, da maioria dos membros dos órgãos de administração, de direção ou de fiscalização de uma outra empresa. A sociedade consolidadora presumivelmente terá efetuado aquela designação quando ela tiver detido no curso daquele período, diretamente ou indiretamente, uma fração superior a $40 \%$ dos direitos de voto, e desde que nenhum outro sócio ou acionista não tenha detido, diretamente ou indiretamente, uma fração superior à dela; $3^{\circ}$ Seja do direito de exercer uma influência dominante sobre uma empresa em razão de um contrato ou de cláusulas estatutárias, quando o direito aplicável permitir.") (Disponível em <http://www.legifrance.gouv.fr/affichCode.do;jsessionid=58086CD4BD27723D00CCA8460E177646.tpdjo1 4v_1?cidTexte=LEGITEXT000005634379\&dateTexte=20140330>. Acesso em 30.03.2014. 
Há que se ressaltar, também, que nos termos do artigo L233-16, inciso IV $^{291}$, do Código Comercial, com a redação dada pela Lei n. ${ }^{\circ}$ 2003-706, de 01.08.2003, situado na Seção 3 (do Capítulo III - Das filiais, das participações e das sociedades controladas, do Título III - Disposições comuns às diversas sociedades comerciais), que cuida das contas consolidadas, a influência dominante ativa do acionista controlador não se confunde com a influência notável sobre a gestão e a política financeira de sociedade, que é presumida sempre que uma sociedade detiver, direta ou indiretamente, uma participação pelo menos igual a $5 \%$ dos direitos de voto.

Logo, constata-se que, segundo a definição do Direito Francês, o poder de controle possui predominantemente uma natureza estratégica e não financeira, além de fundar-se basicamente na ideia de influência determinante, que, segundo a doutrina ${ }^{292}$, consiste na submissão do funcionamento de toda a companhia a um centro de decisão, de modo que não importa a forma de obtenção desta influência determinante, mas, sim, o resultado obtido, isto porque o poder de controle é polimorfo, por isso o poder de controle é definido pelos resultados obtidos e não pela forma utilizada para obtê-lo.

Nesse sentido é o ensinamento de Jacques Barthélémy et alii: “ Exercer o controle sobre uma sociedade, consiste em submetê-la à dependência de um centro de decisão (...)É por isso que, pelo resultado obtido, e não pelo meio utilizado para obtê-lo, que o controle é definido." 293 (Tradução livre)

\footnotetext{
291 “Article L233-16 (...)IV. - L'influence notable sur la gestion et la politique financière d'une entreprise est présumée lorsqu'une société dispose, directement ou indirectement, d'une fraction au moins égale au cinquième des droits de vote de cette entreprise." (Tradução livre: "Artigo L233-16 (...) IV. - A influência notável sobre a gestão e a política financeira de uma empresa é presumida quando uma sociedade detiver, diretamente ou indiretamente, uma fração pelo menos igual a 5\% dos direitos de voto daquela empresa.") (Disponível em <http://www.legifrance.gouv.fr/affichCode.do;jsessionid=58086CD4BD27723D00CCA8460E177646.tpdjo1 $4 \mathrm{v} \_1$ ? cidTexte=LEGITEXT000005634379\&dateTexte=20140330>. Acesso em 30.03.2014.

${ }^{292}$ "Si la participacion se réalise nécessairement par un seul moyen (l'acquisition d'une quotité du capital d'une autre société) et a, par conséquent, une nature purement financière, le contrôle au contraire est polymorphe." (Tradução livre: "Se a participação se realiza necessariamente por um só meio (a aquisição de uma quota-parte do capital de uma outra sociedade) e possui, por consequência, uma natureza puramente financeira, o controle ao contrário é polimorfo.") (BARTHÉLÉMY, Jacques; COULON, Nicolas; EGAL, Jacques ; GUIGOU, Hubert ; HARDOUIN, Michel ; MELLO, Xavier de; PETITEAU, Gérard \& SEURAT, Patrick. Le Droit des Groupes de Sociétés. Paris : Dalloz, 1991, p. 48)

293 "Exercer le controle sur une société, c'est la soumettre à la dépendance d'une centre de décision (...) C'est donc par le résultat obtenu, et non par le moyen mis en oeuvre pour y parvenir, que le contrôle se définit." (Idem, ibidem, p. 48)
} 
Além disso, o poder de controle confere a seu detentor o poder de exercer uma influência dominante, contínua e ativa sobre a gestão da sociedade, que pode ser exercida a qualquer momento e consiste no poder de agir e/ou de fazer agir (em contraposição à influência negativa típica do bloqueio exercido pelos minoritários), conferindo à gestão uma orientação, o que é efetivado por meio da detenção dos meios de nomeação e destituição dos membros dos órgãos de administração, de direção ou de fiscalização da companhia, de modo a determinar as grandes diretrizes de desenvolvimento e as decisões estratégicas, ou seja, de maneira a permitir a execução da política desejada com vistas a engajar os investimentos e obter o crescimento econômico da empresa. ${ }^{294}$

Portanto, segundo a doutrina francesa, a manifestação do exercício do poder de controle não se restringe ao exercício do direito de voto em assembleias, que, na verdade, constitui apenas uma forma de sua manifestação, sendo imprescindível que o controlador possa influenciar as estruturas internas da companhia, permitindo-lhe, assim, a dominação ou o controle das decisões relevantes e orientadoras da gestão, isto porque " $O$ controle é exercido apenas por intermédio dos órgãos de gestão (...) Isto significa que o controle consiste na detenção dos meios de nomear (e, se necessário, de destituir) os órgãos de gestão (...): gerência, conselho de administração ou diretoria." ${ }^{295}$ (tradução livre)

${ }^{294}$ Vide BARTHÉLÉMY, Jacques; COULON, Nicolas; EGAL, Jacques ; GUIGOU,Hubert ; HARDOUIN, Michel ; MELLO, Xavier de; PETITEAU, Gérard \& SEURAT, Patrick. Le Droit des Groupes de Sociétés. Paris : Dalloz, 1991, p. 48 a p. 49.

295 "Le contrôle ne s'exerce donc que par l'intermédiaire des organes de gestion (...) Ce qui signifie que le contrôle consiste à detenir le moyen de nommer ( et, le cas échéant, de révoquer) les organes de gestion (...): gérance, conseil d'administration ou directoire." (Idem, ibidem, p. 48) 


\subsection{O DIREITO INGLÊS}

No âmbito do Direito Societário, a Inglaterra é vista, pelos doutrinadores europeus, como sendo o país em que o Direito Societário Moderno teve seu surgimento, tendo, dentre os outros países, a mais longa experiência em direito societário ${ }^{296}$, sem se considerar que se trata de um direito que estabelece um ponto de ligação entre o velho continente europeu e a ex-colônia inglesa dotada de uma grande pujança econômica, qual seja os Estados Unidos da América.

Segundo André Tunc ${ }^{297}$, enquanto os Estados Unidos da América apresentam um direito societário reconhecidamente eficaz e dotado de moralidade ao qual corresponde simetricamente um capitalismo moderno, tudo isso existe à custa de uma regulamentação forte e complexa, a Inglaterra, por outro lado, atinge os mesmos objetivos, mas por meios mais simples e leves.

Acrescente-se, ainda, que segundo Fábio Konder Comparato, a primeira definição de controle no Direito Societário Moderno surgiu no Direito Inglês, mais especificamente no julgamento do caso Daimle Co., Ltd. V. Continental Tyre and Ruber Co. Ltd. 2.A.C. 307 (1916).

Estas são as principais razões para o estudo das sociedades anônimas no Direito Societário Inglês.

Segundo os relatos históricos dos doutrinadores, somente a partir da metade do Século XIX o Direito Societário inglês assumiu as feições modernas mais próximas da atualidade. Após inúmeras revisões normativas, vigora, hodiernamente, na Inglaterra o

\footnotetext{
296 “ D'autre part, le droit anglais des sociétés est particulièrement important pour les juristes continentaux soucieux d'améliorer leur propre droit. L'Anglaterre est, en effet., la patrie d'origine, en quelque sorte, du droit moderne des sociétés. C'est elle qui a acquis dans ce droit la plus longue expérience." (Tradução livre: "De outra parte, o direito inglês das sociedades é particularmente importante para os juristas continentais preocupados em melhorar seu próprio direito. A Inglaterra é, realmente, a pátria de origem, de qualquer sorte, do direito moderno das sociedades. É ela que adquiriu neste direito a mais longa experiência.") (TUNC, André. Le Droit Anglais Des Sociétés Anonymes. 2. ${ }^{a}$ edição. Paris : Dalloz, 1978, p. 2)

${ }^{297}$ Idem, ibidem, p. 2.
} 
Companies Act $2006^{298}$, que é o diploma legal que reformou e reafirmou grande parte dos atos legislativos relativos ao direito societário.

Não obstante sua importância como referência normativa ao direito societário inglês, o Companies Act 2006 traz uma definição de acionista controlador apenas na Parte 43, que possui normas de harmonização do dever de transparência (e matérias correlatadas) aos emissores de valores mobiliários, que são admitidos para negociação no mercado de capitais.

Assim, o parágrafo 1167, em seu subparágrafo 4, define controlador como sendo a pessoa que (a) detiver a maioria dos votos na sociedade controlada, (b) sendo membro da sociedade controlada, tiver o direito de nomear ou destituir os membros da diretoria ou de órgão administrativo equivalente, (c) sendo um membro da sociedade controlada, controla sozinha a maioria dos votos na controlada, em virtude da celebração de acordo com outros acionistas ou membros ou (d) tiver o direito de exercer ou efetivamente exerce influência dominante ou controle sobre a sociedade controlada. ${ }^{299}$

Para todos os efeitos, deve-se ressaltar que, no âmbito do Direito Inglês, considera-se membro de uma sociedade os subscritores do contrato social, os diretores que tiverem assinado um compromisso de pagar por suas ações, caso em que é equiparado aos membros que assinaram o contrato social, bem como todas as outras pessoas que concordaram em tornarem-se membros da sociedade. Em relação às companhias, os seus membros são os acionistas.

Nesse sentido, é o ensinamento de John Charlesworth et al.:

\footnotetext{
${ }^{298}$ Disponível em <http://www.legislation.gov.uk/ukpga/2006/46/contents>. Acesso em 27.04.2014

299 “(4) For the purposes of those sections a person ("A”) controls another person ("B") if - (a) A holds a majority of the voting rights in $B,(b) A$ is a member of $B$ and has the right to appoint or remove a majority of the members of the board of directors (or, if there is no such board, the equivalent management body) of $B$, (c) $A$ is a member of $B$ and controls alone, pursuant to an agreement with other shareholders or members, a majority of the voting rights in $B$, or $(d) A$ has the right to exercise, or actually exercises, dominant influence or control over B." (Tradução livre: “(4) Para efeitos destas seções a pessoa ("A”) controla outra pessoa (" $B$ ") se - (a) A detiver a maioria dos direitos de votar em $B$, (b) A for um membro de $B$ e tiver o direito de nomear ou remover a maioria dos membros da diretoria (ou, se não existir tal diretoria, o órgão administrativo equivalente) de B, (c) A for membro de B e controlar sozinho, em razão de um acordo celebrado com outro acionista ou membros, uma maioria de direitos de voto em $B$, ou (d) A tiver o direito de exercer, ou efetivamente exerce, influência dominante ou controle sobre B."). Disponível em <http://www.legislation.gov.uk/ukpga/2006/46/contents>. Acesso em 27.04.2014.
} 
"Os membros de uma companhia consistem em:

(1) Os subscritores do contrato social (...)

(2) Os diretores que tiverem assinado e entregue ao Registro uma promessa de aceitar e pagar por suas ações de qualificação. Tais diretores estão na mesma posição como se tivessem assinado o contrato social (...)

(3) Todas as outras pessoas que concordaram em se tornar membros da companhia (...)

No caso de companhia limitada por ações, os acionistas sã os membros." 300 (tradução livre)

Além disso, o Anexo 7, que trata das disposições complementares às sociedades holding e controlada, contendo especialmente explicações de expressões e termos utilizados no Companies Act 2006 referentes àquelas sociedades, indica, no parágrafo 4, subparágrafo 1 , que se deve entender por exercício de influência dominante sobre outra empresa quando a controladora "tiver o direito de dar orientações referentes às política operacional e financeira daquela outra empresa, as quais seus diretores deverão cumprir". (tradução livre) $)^{301}$

Acrescente-se, ainda, que o Anexo 10 - Órgão Supervisor Oficial (Schedule 10 - Recognised Supervisory Body), no subparágrafo 4, do parágrafo 8, da Parte 2, do

\footnotetext{
300 "The members of a company consist of: (1) The subscribers of the memorandum (...) (2) Directors who have signed and delivered to the Registrar an undertaking to take and pay for their qualification share. Such directors are in the same position as if they had signed the memorandum for shares (...) (3) All other persons who have agreed to become members of the company (...) In the case of a company limited by shares the shareholders are the members." (CHARLESWORTH, John; CAIN, Thomas Ewan; MORSE, Geoffrey; MARSHALL, Enid A.; MORRIS, Richard Colin. Company Law. $10^{a}$ edição. Londres: Stevens \& Sons, 1972, p. 146)

301 "4 (1) For the purposes of section 1162(2)(c) an undertaking shall not be regarded as having the right to exercise a dominant influence over another undertaking unless it has a right to give directions with respect to the operating and financial policies of that other undertaking which its directors are obliged to comply with whether or not they are for the benefit of that other undertaking." Disponível em <http://www.legislation.gov.uk/ukpga/2006/46/contents〉. Acesso em 27.04.2014.
} 
Companies Act $2006^{302}$, também define controlador, mas como sendo a pessoa que, individual ou conjuntamente, exerce ou controla o exercício de 15\% (quinze por cento ou mais dos votos em todas ou substancialmente em todas as matérias postas em votação nas assembleias gerais.

O subparágrafo 1 do parágrafo 1159 do Companies Act $2006^{303}$, por sua vez, ao definir companhia subsidiária ${ }^{304}$, agrega elementos que ajudam a definir o que seja o acionista controlador. Assim, segundo aquele dispositivo legal será considerada companhia controladora da companhia subsidiária aquela companhia que (a) detiver a maioria de votos, (b) é acionista da companhia subsidiária e possui o direito de nomear ou destituir a maioria dos diretores ou (c) é uma acionista da companhia subsidiária e controla-a individualmente ou em razão de acordo celebrado com outros acionistas a maioria dos votos.

Além do Companies Act 2006, há o The City Code on Takeovers and Mergers, que é um diploma que tem por fim precípuo "assegurar que os acionistas, em

302 “(4) In sub-paragraph (2)(b) and (c) "controller”, in relation to a body corporate, means a person who either alone or with an associate or associates is entitled to exercise or control the exercise of $15 \%$ or more of the rights to vote on all, or substantially all, matters at general meetings of the body or another body corporate of which it is a subsidiary." (Tradução livre: “(4) No subparágrafo (2) (b) e (c) 'controlador', em relação a uma companhia, significa uma pessoa que ou sozinha ou com um associado ou associados está autorizado a exercer ou controlar o exercício de $15 \%$ ou mais dos direitos de voto em todas, ou substancialmente todas, matérias nas assembleias gerais da companhia ou de outra companhia que é sua subsidiária."). Disponível em < http://www.legislation.gov.uk/ukpga/2006/46/contents>. Último acesso em 27.04.2014.

303 “(1) A company is a "subsidiary" of another company, its "holding company", if that other company(a) holds a majority of the voting rights in it, or $(b)$ is a member of it and has the right to appoint or remove a majority of its board of directors, or (c) is a member of it and controls alone, pursuant to an agreement with other members, a majority of the voting rights in it, or if it is a subsidiary of a company that is itself a subsidiary of that other company." (Tradução livre: “(1) Uma companhia é uma 'subsidiária' de outra companhia, sua controladora, se aquela outra companhia - (a) detiver a maioria dos direitos de voto nela, ou (b) for uma acionista dela e tiver o direito de nomear ou destituir a maioria dos membros da diretoria, ou (c) for uma acionista dela e detiver, individualmente ou em decorrência de um acordo celebrado com outros acionistas, a maioria dos direitos de voto nela, ou se for uma subsidiária de uma companhia que é por si uma subsidiária daquela outra companhia.”). Disponível em <http://www.legislation.gov.uk/ukpga/2006/46/contents>. Último acesso em 27.04.2014.

${ }^{304}$ Observe-se que, segundo o Direito Inglês, uma companhia pode ser considerada como subsidiária quando for "uma companhia controlada por outra companhia, sua companhia holding (ou mãe). Para fins gerais, tal controle é estabelecido quando a companhia holding tiver a maioria dos direitos de votos decorrentes de suas ações (tanto em razão da propriedade daquelas ações ou em virtude de um acordo com outros acionistas) ou o direito de nomear ou destituir a maioria dos diretores." (Tradução livre de: "Subsidiary company A company controlled by another company, its holding (or parent) company. For general purposes, such control is established when the holding company has a majority of the voting rights attached to its shares (either by virtue of its ownership of those shares or because of an agreement with other shareholders) or the right to appoint or remove a majority of its board of directors." In: MARTIN, Elizabeth A. A Dictionary of Law. $5^{\text {a }}$ edição. Oxford: Oxford, 2002, p. 483) 
uma empresa alvo, sejam tratados justamente e não lhes seja negada a oportunidade de decidir sobre a aquisição no mérito e que os acionistas de uma mesma classe em uma companhia alvo tenham um tratamento equivalente pelo ofertante", sem prejuízo de "prover uma estrutura organizada dentro da qual a aquisição seja conduzida" além de "ser projetado para promover, em conjunto com outros regimes regulatórios, a integridade do mercado financeiro." 305 (tradução livre)

O referido diploma foi desenvolvido em consonância com as previsões constantes do Capítulo 1 da Parte 28 do Companies Act 2006, cuja administração e aplicação são atribuídas a um órgão autorregulatório independente, o Panel on Takeovers and Mergers, que foi criado em 1968.

As transações sujeitas à incidência do The City Code on Takeovers and Mergers envolvem não só as aquisições de controle e as fusões, mas também toda e qualquer outra espécie de transação que tenha por objetivo ou, ainda, como potencial efeito, direto ou indireto, a obtenção ou consolidação do poder de controle das companhias, conforme previsto na alínea (b), do item 3 (Companies, transactions and persons subject to the Code), da Introdução daquele diploma legal.

As supra mencionadas transações podem ser efetuadas individualmente ou conjuntamente, sendo que o The City Code on Takeovers and Mergers, em suas definições, considera que duas ou mais pessoas atuam de comum acordo quando, "em razão de um acordo ou entendimentos (formal ou informal), cooperam para obter ou consolidar o controle (...) de uma companhia ou para frustrar o resultado bem sucedido de uma oferta pela companhia", sendo que "a pessoa e cada uma de suas associadas serão consideradas como atuando conjuntamente umas com as outras". 306 (tradução livre)

\footnotetext{
305 "The Code is designed principally to ensure that shareholders in an offeree company are treated fairly and are not denied an opportunity to decide on the merits of a takeover and that shareholders in the offeree company of the same class are afforded equivalent treatment by an offeror. The Code also provides an orderly framework within which takeovers are conducted. In addition, it is designed to promote, in conjunction with other regulatory regimes, the integrity of the financial markets." (In: The City Code on Takeovers and Mergers, versão de 30.09.2013 e vigente em 27.04.2014, p. 29. Disponível em <https://www.frc.org.uk/Our-Work/Publications/Corporate-Governance/UK-Corporate-Governance-CodeSeptember-2012.pdf $>$. Acesso em 27.04.2014)

306 "Persons acting in concert comprise persons who, pursuant to an agreement or understanding (whether formal or informal), co-operate to obtain or consolidate control (as defined below) of a company or to frustrate the successful outcome of an offer for a company. A person and each of its affiliated persons will be
} 
Por sua vez, deve-se considerar associadas qualquer sociedade da qual outra sociedade "(a) tem a maioria dos direitos de voto dos acionistas ou membros; (b) é um acionista ou membro e a mesmo tempo tem o direito de nomear ou destituir a maioria dos membros da diretoria; (c) é um acionista ou membro e individualmente controla a maioria dos direitos dos votos dos acionistas ou membros em virtude de um acordo celebrado com outros acionistas ou membros; ou (d) tem o poder de exercer, ou efetivamente exerce, influência dominante ou o controle. ${ }^{, 307}$ (tradução livre)

O mencionado The City Code on Takeovers and Mergers, para efeitos de sua aplicação, possui uma definição de controle, segundo a qual "controle significa um interesse, ou interesses, em ações que agregam $30 \%$ ou mais dos direitos de votos (como definido abaixo) de uma companhia, independentemente deste interesse ou interesses outorgarem o controle de fato."308 (tradução livre)

Para este efeito, considera-se como tendo interesse ou interesses em valores mobiliários, toda "pessoa que tiver exposição econômica longa, absoluta ou condicional, às mudanças no preço dos valores mobiliários"309, especialmente se: “(1) ela for

deemed to be acting in concert all with each other (see Note 2 below)." (In: The City Code on Takeovers and Mergers, versão de 30.09.2013 e vigente em 27.04.2014, p. 53. Disponível em <https://www.frc.org.uk/OurWork/Publications/Corporate-Governance/UK-Corporate-Governance-Code-September-2012.pdf $>$ Acesso em 27.04.2014)

307 "For the purposes of this definition an "affiliated person"' means any undertaking in respect of which any person:

(a) has a majority of the shareholders' or members' voting rights;

(b) is a shareholder or member and at the same time has the right to appoint or remove a majority of the members of its board of directors;

(c) is a shareholder or member and alone controls a majority of the shareholders' or members' voting rights pursuant to an agreement entered into with other shareholders or members; or

(d) has the power to exercise, or actually exercises, dominant influence or control."(In: The City Code on Takeovers and Mergers, versão de 30.09.2013 e vigente em 27.04.2014, p. 54. Disponível em <https://www.frc.org.uk/Our-Work/Publications/Corporate-Governance/UK-Corporate-Governance-Code-

September-2012.pdf>. Acesso em 27.04.2014)

308 " Control

Control means an interest, or interests, in shares carrying in aggregate $30 \%$ or more of the voting rights (as defined below) of a company, irrespective of whether such interest or interests give de facto control." (In: The City Code on Takeovers and Mergers, versão de 30.09.2013 e vigente em 27.04.2014, p. 58. Disponível em <https://www.frc.org.uk/Our-Work/Publications/Corporate-Governance/UK-Corporate-GovernanceCode-September-2012.pdf $>$. Acesso em 27.04.2014)

309 "A person who has long economic exposure, whether absolute or conditional, to changes in the price of securities will be treated as interested in those securities. A person who only has a short position in securities will not be treated as interested in those securities." (Tradução livre: "Uma pessoa que tem uma longa exposição econômica, absoluta ou condicional, a mudanças do preço dos valores mobiliários será considerada como tendo interesse naqueles valores mobiliários. Uma pessoa que apenas tem uma curta exposição não será considerada como tendo interesse naqueles valores obliários.") (In: The City Code on Takeovers and Mergers, versão de 30.09.2013 e vigente em 27.04.2014, p. 62. Disponível em 
proprietária deles; (2) ela tiver o direito (condicional ou absoluto) de exercer ou dirigir o exercício dos direitos de voto decorrentes deles ou possuir controle geral deles; (3) em razão de qualquer contrato de compra, opção ou derivado ele (a) possuir o direito ou opção de adquiri-los ou solicitar sua entrega; ou (b) encontra-se sujeito a uma obrigação de aceitar a entrega deles (...); ou ela é parte de qualquer derivativo (a) cujo valor é determinado por referência a seu preço e (b) cujos resultados, ou possível resultado, em se valor tiver uma longa posição neles; e (5) (...) ela tiver recebido um compromisso irrevogável a respeito deles." 310 (tradução livre)

Em nota às definições, o The City Code on Takeovers and Mergers indica que o teste normal para verificar se uma pessoa é controlada, controladora ou está sob o mesmo controle de outra pessoa será por referência à definição de controle constante daquele diploma ${ }^{311}$

Ademais, o referido diploma legal excepciona da definição de controle a situação encontrada em casos de atuação de intermediários oficiais, que são aquelas pessoas pertencentes ao setor de "operações de compra e venda de banco ou corretora de valores mobiliários que são aceitas como intermediário oficial"312 (tradução livre), atuam

<https://www.frc.org.uk/Our-Work/Publications/Corporate-Governance/UK-Corporate-Governance-CodeSeptember-2012.pdf >. Acesso em 27.04.2014)

310 "In particular, a person will be treated as having an interest in securities if:

(1) he owns them;

(2) he has the right (whether conditional or absolute) to exercise or direct the exercise of the voting rights attaching to them or has general control of them;

(3) by virtue of any agreement to purchase, option or derivative he:

(a) has the right or option to acquire them or call for their delivery; or

(b) is under an obligation to take delivery of them,

whether the right, option or obligation is conditional or absolute and whether it is in the money or otherwise; or

(4) he is party to any derivative:

(a) whose value is determined by reference to their price; and

(b) which results, or may result, in his having a long position in them;

and

(5) in the case of Rule 5 only, he has received an irrevocable commitment in respect of them." (In: The City Code on Takeovers and Mergers, versão de 30.09.2013 e vigente em 27.04.2014, p. 62 e p. 63. Disponível em <https://www.frc.org.uk/Our-Work/Publications/Corporate-Governance/UK-Corporate-GovernanceCode-September-2012.pdf $>$. Acesso em 27.04.2014)

311 Vide The City Code on Takeovers and Mergers, versão de 30.09.2013 e vigente em 27.04.2014, p. 73, disponível em <https://www.frc.org.uk/Our-Work/Publications/Corporate-Governance/UK-CorporateGovernance-Code-September-2012.pdf>. Acesso em 27.04.2014.

312 "A recognised intermediary is that part of the trading operations of a bank or securities house which is accepted by the Panel as a recognized intermediary for the purposes of the Code."(In: The City Code on Takeovers and Mergers, versão de 30.09.2013 e vigente em 27.04.2014, p. 68. Disponível em 
como prestadores de serviços a clientes, caso em que não serão considerados como detentores de interesse em valores mobiliários, bem como os componentes do grupo não se submeterão à obrigação de fazer oferta pública de aquisição de ações aos demais acionistas, desde que as ações de certa companhia agregadas pelo grupo de pessoas representado pelo intermediário oficial, excedendo a $30 \%$ dos direitos de votos, não apresente nenhum componente deste grupo com direitos de votos superior a $3 \% \mathrm{em}$ nenhum momento. ${ }^{313}$

Segundo a doutrina inglesa, o poder de controle reside no controle substancial exercido sobre os negócios da empresa ${ }^{314}$ pelo acionista detentor de $30 \%$ ou mais das ações votantes, seja individualmente, seja em razão da celebração de acordo com outros acionistas, controle este que em regra incide sobre as decisões principais, o que implica no exercício de influência sobre a administração que, por sua vez, resulta no poder de nomear ou destituir os administradores, bem como da habilidade de formar uma coalizão de votos ${ }^{315}$.

<https://www.frc.org.uk/Our-Work/Publications/Corporate-Governance/UK-Corporate-Governance-CodeSeptember-2012.pdf $>$. Acesso em 27.04.2014)

313 "If such a group of persons includes a principal trader and the aggregate number of shares in a company in which the group is interested approaches or exceeds $30 \%$ of the voting rights, the Panel may consent to the principal trader continuing to acquire interests in shares in the company without consequence under Rule 9.1 provided that the company is not in an offer period and the number of shares which the principal trader holds does not at any relevant time exceed 3\% of the voting rights of the company. The Panel should be consulted in such cases." (Tradução livre: "Se tal grupo de pessoas incluir um negociador principal e o número de ações agregadas de uma companhia, na qual o grupo tiver interesse aproximar ou exceder $30 \%$ dos direitos de voto, o Comitê pode consentir que o negociador principal continue a adquirir interesses em ações da companhia sem as consequências da Regra 9.1 desde que a companhia não esteja em um período de oferta e o número de ações que o negociados principal detiver não exceda a $3 \%$ dos direitos de voto da companhia em nenhum momento. O Comitê deve ser consultado em tais casos.") (In: The City Code on Takeovers and Mergers, versão de 30.09 .2013 e vigente em 27.04.2014, p. 68. Disponível em <https://www.frc.org.uk/Our-Work/Publications/Corporate-Governance/UK-Corporate-Governance-CodeSeptember-2012.pdf $>$. Acesso em 27.04.2014)

314 "Consequently, in legal terms, shareholders have substantial control over corporate affairs." (Tradução livre: "Consequentemente, em termos legais, os acionistas possuem o controle substancial sobre os negócios da companhia.") (CHEFFINS, Brian R. Company Law: Theory, Structure, and Operation. Grã-Bretanha: Clarendon Press - Oxford, 2005, p. 61 - 62)

315 "However, it is difficult to generalize about the degree of influence which they will have. When a single individual or a cohesive coalition of shareholders owns a majority of shares, exercising influence over management will be relatively straightforward. This is because the dominant shareholder(s) can choose who sits on the company's board and the directors in turn can select executives the dominant shareholder(s) thinks are suitable. Otherwise, the degree of influence will depend on the circumstances. Important factors will be the number of other investors with a substantial stake in the company, the blockholder's ability to form voting coalitions, and the voting rules in effect for a particular decision."(Tradução livre: "Entretanto, é difícil generalizar o grau de influência que eles terão. Quando um único acionista ou uma coalizão coesa de acionistas possuir a maioria das ações, o exercício de influência sobre a administração será direta. Isto porque o(s) acionista(s) dominante $(s)$ pode $(m)$ escolher quem ocupará os cargos de administração e os 
Ademais, o poder de controle, ainda que exercido de maneira mais branda, revela um poder de controle latente que será considerado um fator limitador da liberdade de ação da administração da companhia, o que se verificará por meio do exercício do poder de veto, do poder de consulta, do poder de determinar o que deve ser feito e do poder de substituir a administração ${ }^{316}$, tendo, ainda, o acionista controlador "o dever de atuar com boa fé em benefício da companhia como um todo (...) e não cometer fraude contra a minoria". ${ }^{317}$ (tradução livre)

Desse modo, o poder de controle reside na supervisão interna, cujo conceito é a base do modelo de propriedade, sendo a referida supervisão fundamental para que a companhia tenha um governo efetivo.

Observe-se que, segundo os relatos da doutrina, a dispersão da propriedade das ações tornou o exercício do poder de controle mais atenuado nas grandes companhias de capital aberto ${ }^{318}$, isto em razão do aumento da quantidade de pequenos acionistas interessados apenas nos dividendos e com pouco interesse e/ou expertise para engajar-se nos negócios da companhia, bem como permitiu o seu exercício com a detenção da titularidade de ações votantes inferior a 50\% (cinquenta por cento).

Assim, da análise das normas e da doutrina inglesa, pode-se concluir que, no âmbito do direito inglês, o poder de controle consiste na atribuição do poder empresarial ao detentor, individual ou conjunto (este por meio da celebração de acordo de acionistas), da titularidade dos direitos de acionista equivalente a $30 \%$ (trinta por cento) ou mais das ações com direito de voto, de maneira a garantir-lhe o controle das decisões principais e a supervisão interna da estrutura organizacional da companhia, seja exercendo uma

diretores, por sua vez, podem selecionar executivos que sejam considerados adequados pelo (s) acionista $(s)$ dominante(s). Por outro lado, o grau de influência dependerá de algumas circunstâncias. Serão considerados como fatores importantes o número de outros acionistas investidores com participação substancial na companhia, a habilidade do controlador de formar coalizão de voto e as regras para o exercício do direito de voto para decisões específicas.") (CHEFFINS, Brian R. Company Law: Theory, Structure, and Operation. Grã-Bretanha: Clarendon Press - Oxford, 2005, p. 63)

${ }^{316}$ Vide PARKINSON, John E. Corporate Power and Responsability - Issues in the Theory of Company Law. Nova Iorque: Oxford University Press, 2002, p. 62.

317 "Controlling members owe a duty to the company to act bona fide for the benefit of the company as whole, i.e., the corporators as a general body, and not to commit a fraud on the minority by expropriating the property of the company." (CHARLESWORTH, John; CAIN, Thomas Ewan; MORSE, Geoffrey; MARSHALL, Enid A.; MORRIS, Richard Colin. Company Law. 10 a edição. Londres: Stevens \& Sons, 1972, p. 302)

${ }^{318}$ Vide PARKINSON, John E. Corporate Power and Responsability - Issues in the Theory of Company Law. Nova Iorque: Oxford University Press, 2002, p. 54. 
influência dominante sobre toda a administração, seja detendo o poder de nomear e destituir a maioria dos membros da administração, além da prevalência substancial na maioria das decisões tomadas em assembleia geral.

Portanto, em síntese e segundo as palavras de Brian R. Cheffins, “aqueles que controlam a companhia têm o poder de determinar a estratégia negocial da empresa. Em outras palavras, eles têm autoridade para determinar os objetivos de longo prazo do negócio e para decidir de como estes objetivos serão atingidos. ${ }^{„ 319}$ (tradução livre)

319 "Those who control a comapny have the power to determine the business strategy of the enterprise. In other words, they have the authority to ascertain the long-term objectives of the business and to decide how those objectives are to be met." (CHEFFINS, Brian R. Company Law: Theory, Structure, and Operation. Grã-Bretanha: Clarendon Press - Oxford, 2005, p. 44) 


\section{OS ELEMENTOS ESSENCIAIS DO PODER DE CONTROLE}

Feito este breve estudo do poder de controle no Direito Comparado, pode-se perceber que o poder de controle é um fenômeno econômico-social, que está situado no plano dos fatos, é muito amplo e, como bem ressaltou Jacques Barthélémy et alli ${ }^{320}$, é polimorfo, em virtude da sua manifestação apresentar uma grande variabilidade, de modo que, ao ser qualificado juridicamente, pelo legislador, inevitavelmente o poder de controle sofre limitações.

Como ponderou Fábio Konder Comparato, "a análise do fenômeno não deve reduzir-se a aspectos legais, sob pena de mirrar-se numa exegese estéril de palavras. O exercício do poder, em qualquer sociedade, nem sempre se ajusta ao modelo normativo. Há poderes de fato e poderes de direito, assim como há soberanias efetivas e soberanias meramente formais, destituídas de qualquer efetividade."321

Com o legislador brasileiro não foi diferente, o conceito legal de poder de controle presente no art. 116 da lei n. ${ }^{\circ}$ 6.404/76 restringiu o fenômeno econômico-social do poder de controle primordialmente ao exercício do direito de voto, seja exigindo preponderância nas deliberações assembleares, seja exigindo o poder de eleger e destituir a maioria dos administradores, também por meio do exercício do direito de voto nas assembleias gerais, excluindo do conceito legal aspectos do poder de controle tão importantes quanto o exercício do direito de voto nas assembleias gerais, e que também caracterizam o exercício poder de controle.

Esta, inclusive, foi a crítica feita por Eduardo Secchi Munhoz:

"A principal crítica a ser apresentada refere-se exatamente ao núcleo da definição legal, ao restringir o fenômeno do controle ao mecanismo societário, ligando-o à preponderância nas deliberações sociais e ao

\footnotetext{
${ }^{320}$ BARTHÉLÉMY, Jacques; COULON, Nicolas; EGAL, Jacques ; GUIGOU, Hubert ; HARDOUIN, Michel ; MELLO, Xavier de; PETITEAU, Gérard \& SEURAT, Patrick. Le Droit des Groupes de Sociétés. Paris : Dalloz, 1991, p. 48

${ }^{321}$ COMPARATO, Fábio Konder; SAlOMÃo FILHO, Calixto. O Poder de Controle na Sociedade Anônimas. 4. ${ }^{a}$ edição. Rio de Janeiro: Forense, 2005, p. 45 a p. 46.
} 
poder de eleger a maioria dos administradores, ou seja, o exercício do direito de voto., 322

Embora a maioria dos doutrinadores acabe por identificar o poder de controle ao exercício do direito de voto, o estudo do Direito Comparado mostrou que há identificação do poder de controle ao exercício de influência dominante ativa e contínua ou, como denominado no direito norte-americano, ao exercício de influência controladora sobre toda a companhia, enquanto conjunto de órgãos internos organizados hierarquicamente, cuja manifestação pode ocorrer de diversas maneiras, tais como, exemplificativamente, o exercício do poder de dirigir ou de determinar a direção da companhia, a submissão dos órgãos internos da companhia a um centro de decisões, a determinação das diretrizes primordiais da política da companhia, a tomada de decisões estratégicas, relevantes e orientadoras da administração fora do âmbito de competência da Assembleia Geral etc.

Assim, o poder de controle, além de seu valor econômico, denota um grande valor estratégico para o exercício da empresa e, consequentemente, para a consecução de seu objeto social e o cumprimento de sua função social, visando à obtenção da maior lucratividade possível e pelo modo mais eficiente possível em benefício de toda a companhia.

Desse modo, talvez fosse aconselhável não limitar o conceito legal, basicamente, ao exercício do direito de voto, isto porque, como bem ressaltou Tercio Sampaio Ferraz Junior ${ }^{323}$, o exercício de poder, enquanto meio de comunicação, dentro de relações estabelecidas entre o sujeito detentor do poder e os sujeitos submetidos ao poder voluntariamente, possui uma estrutura hierárquica, cuja função principal não é suprimir a expressão da vontade dos sujeitos submetidos ao poder, mas sim contingenciá-la.

\footnotetext{
${ }^{322}$ MUNHOZ, Eduardo Secchi. Empresa Contemporânea e Direito Societário - Poder de Controle e Grupos de Sociedades. São Paulo: Juarez de Oliveira, 2002, p. 245.

323 "A função do poder como meio codificado de comunicação apenas coloca possíveis relações causais como simbolicamente independentes da vontade do submetido. Ou seja, a 'causalidade' do poder (como a imputação, no direito) consiste não em quebrar a vontade do submisso, mas em neutralizar sua vontade (que existe, mas não conta para efeitos significativos). A função do poder/medium está na regulação da contingência (possibilidade causal de ocorrer A ou B) e não em sua supressão." (FERRAZ JUNIOR, Tercio Sampaio. Estudos de Filosofia do Direito: Reflexões sobre o Poder, a Liberdade, a Justiça e o Direito.

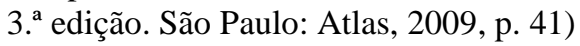


O contingenciamento da vontade dos sujeitos obedientes consiste, conforme Tercio Sampaio Ferraz Junior, na redução da complexidade das possibilidades de ação dos agentes submetidos ao poder, ou seja, na limitação das possibilidades de escolhas a serem feitas pelos submetidos ao poder, redução esta que também atinge o próprio detentor do poder ao exercê-lo efetivamente ${ }^{324}$, de modo que a "consequência imediata disso é que o poder não é o instrumento de uma vontade sobre outra, mas como medium de comunicação, ele instrumentaliza, não uma vontade já dada, e sim uma vontade por ele (enquanto meio) produzida, vinculando-a, sujeitando-a, conduzindo-a ao sucesso na absorção de riscos ou levando-a a fracasso." 325

A instrumentalização da vontade produzida pelo poder enquanto meio e o contingenciamento das possibilidades de ação dos sujeitos submetidos ao poder são possíveis por meio da autoridade ${ }^{326}$, liderança $^{327}$ e reputação ${ }^{328}$, que são consideradas como três formas de influência que marcam as relações estabelecidas entre o detentor do poder e os agentes sujeitos ao poder e cuja presença conjunta denota a existência de um alto grau de estabilidade do poder, a qual também é conferida pelo Direito.

Assim, constata-se que o exercício do poder de controle é muito mais amplo que o exercício do direito de voto, ainda que este seja a sua manifestação mais importante, tanto que, ao levar alguma ordem do dia à deliberação da Assembleia Geral, o acionista controlador já exercerá o poder de controle ao limitar a matéria que será deliberada pelos demais acionistas em Assembleia Geral, limitando as possibilidades de decisão assemblear diante de uma gama de possibilidades de decisão, ou seja, o controlador limita a

\footnotetext{
324 “(...) não podemos limitar sua análise à ideia de que o fenômeno (do poder) trata apenas da influência do seu detentor no sentido de mover o sujeito a aceitar suas orientações. Pois o código poder realiza uma redução de complexidade, de ambos os lados, ao nível da ação de ambos. Ou seja, também o detentor do poder tem de ser movido para usar o 'seu' poder."(FERRAZ JUNIOR, Tercio Sampaio. Estudos de Filosofia do Direito: Reflexões sobre o Poder, a Liberdade, a Justiça e o Direito. 3. ${ }^{a}$ edição. São Paulo: Atlas, 2009, p. 46)

${ }^{325}$ Idem, ibidem, p. 46.

326 “Dizemos que o detentor do poder influencia porque 'tem autoridade'. Isso ocorre quando seus comandos expressam expectativas normativas (imputação contrafática da responsabilidade pela desilusão) consolidadas por tradição (direito costumeiro) ou por positivação (válidas por decisão) (válidas, efetivas e imperativas)." (Idem, ibidem, p. 71)

327 "Liderança significa, por fim, influência baseada no fortalecimento da prontidão para observância, por meio da experiência de que também outros observam, isto é, mediante imitação" (Idem, ibidem, p. 73)

328 "O detentor do poder goza de reputação quando é capaz de transmitir conteúdos de ação para um sujeito que, então, as assume de modo relativamente acrítico." (Idem, ibidem, p. 72)
} 
complexidade de possibilidades de deliberação assemblear ao levar determinada matéria à deliberação, como bem reconheceu Tercio Sampaio Ferraz Junior, in verbis:

"Assim, por exemplo, as decisões de uma assembleia de acionistas é soberana ainda que, de fato, um grupo minoritário a domine. Isto é, ele a domina não porque tem forca, mas porque outros conteúdos foram neutralizados, isto é, não têm como ser invocados por serem, por exemplo, injustos ou não equitativos. ${ }^{\text {329 }}$ (grifamos)

Desse modo, em razão da amplitude de manifestação do poder de controle no âmbito das sociedades por ações, talvez fosse recomendável conceituá-lo não mais limitando-o ao exercício do direito de voto que é apenas uma parcela da manifestação do exercício do poder de controle, mas o inserindo no contexto da existência de um poder que irradia sobre toda a companhia uma ascendência hierárquica.

A referida ascendência hierárquica, como bem reconhecida pelo Direito Norte-Americano, deve proporcionar ao acionista controlador o poder de dirigir a companhia ou, ainda, de determinar o exercício da direção atribuído a outrem, de forma a sujeitar toda a estrutura organizacional a um centro de decisões, permitindo a existência de uma unidade decisória imperativa e de coordenação das atividades econômicas empresariais.

Nesse sentido, inclusive, é a definição de poder de controle apresentada por Alfredo Lamy Filho e José Luiz Bulhões Pedreira:

"Controle é a capacidade de causar, determinar ou alterar a ação dos órgãos da companhia. É o poder político na sociedade, no sentido de poder supremo da sua estrutura interna, que compreende a capacidade de alocar e distribuir poder nessa estrutura.",330

\footnotetext{
${ }^{329}$ FERRAZ JUNIOR, Tercio Sampaio. Estudos de Filosofia do Direito: Reflexões sobre o Poder, a Liberdade, a Justiça e o Direito. 3. ${ }^{a}$ edição. São Paulo: Atlas, 2009, p. 73.

${ }^{330}$ LAMY FILHO, Alfredo; PEDREIRA, José Luiz Bulhões. A Lei das S.A. Rio de Janeiro: Renovar, 1992, p. 74.
} 
Em relação à sujeição ao centro de decisões, nos termos da legislação francesa, deve ser salientado que não importa a forma pela qual o acionista controlador detém este centro de decisões, tampouco como ele é exercido (diretamente ou por meio de delegação), mas sim a obtenção do resultado consistente na influência determinante sobre toda a companhia como dispõe o Direito Comunitário Europeu, sendo que este resultado caracterizará o exercício do poder de controle.

Ademais, a influência determinante deve ser ativa, ou seja, conforme previsto na legislação francesa, a mesma deve consistir em um efetivo agir do controlador ou, ainda, no ato do controlador fazer outrem agir, contrapondo-se à influência negativa geralmente exercida pelos acionistas minoritários e consistente no efetivo bloqueio de decisões.

Ainda, a influência determinante deve ser contínua no decurso do tempo, ou seja, deve apresentar uma estabilidade que se protraia no tempo, o que não significa que a mesma deva ser considerada como sendo uma imposição absoluta da vontade do controlador, tampouco ser considerada permanente, ou seja imutável, especialmente em um ambiente de dispersão acionária, em que estão presentes constantes disputas pela obtenção do poder de controle, como indicou Eduardo Secchi Munhoz, in verbis:

“Ainda no terreno das críticas, é preciso mencionar que a expressão 'de modo permanente", previstas nos dispositivos antes referidos, gera a ilusão de que o controle é um fenômeno estático, imutável, não sujeito a constantes disputas na vida societária, quando se demonstrou anteriormente que se trata justamente do contrário. Não há dúvida de que o reconhecimento do poder de controle não pode depender de fatos fortuitos, incertos, ou de situações conjunturais, mas a melhor forma de incluir esse requisito na definição geral do fenômeno, certamente, não é empregar a expressão 'permanente', ligada à ideia de imutabilidade no tempo., 331

${ }^{331}$ MUNHOZ, Eduardo Secchi. Empresa Contemporânea e Direito Societário - Poder de Controle e Grupos de Sociedades. São Paulo: Juarez de Oliveira, 2002, p. 249. 
A estabilidade do poder de controle é fundamental para permitir ao acionista controlador a composição harmônica dos diversos interesses, agregando uma força organizadora de todos os interesses e, assim, obter a influência determinante ou controladora que se irradiará sobre toda a estrutura organizacional da sociedade, como bem ressaltou Calixto Salomão Filho em nota de atualização da obra o Poder de Controle na Sociedade Anônima de Fábio Konder Comparato:

"Como se verá a seguir, o controle só pode representar o valor da organização empresarial quando gerar poder estável sobre ela". ${ }^{332}$

Logo, no exercício do poder de controle, conforme preveem as legislações francesa e inglesa, é importante que o acionista controlador detenha o poder de determinar as grandes diretrizes e as decisões estratégicas, relevantes e orientadoras da gestão da companhia, que, no Direito Inglês, são referidas como prevalência substancial nas decisões principais.

Além do exercício de influência dominante ativa e contínua, o controlador, enquanto detentor do poder de supervisão interna da estrutura organizacional da sociedade por ações, deve deter o poder de nomear e/ou destituir os administradores, o que caracteriza o exercício de influência dominante, controladora sobre a administração empresarial, ou seja, deve ser proporcionado ao acionista controlador o exercício de um sistema de controle e punição dos membros da companhia com o fim de proporcionar a organização dos interesses dos diversos agentes internos e, assim, a execução do seu objeto social e da sua função social.

Assim, parece-nos que o legislador brasileiro deveria adotar, no conceito legal de acionista controlador, o conceito de influência dominante ou controladora, como forma de permitir que o conceito mantenha-se aberto a novas formas de expressão do exercício do poder de controle, que, tal como qualquer instituto do Direito Comercial, sofre constantes mudanças e atualizações conforme a realidade empresarial muda e atualiza-se, o que é possível justamente porque o conceito de influência dominante ou controladora é um

332 COMPARATO, Fábio Konder; SAlOMÃo FILHO, Calixto. O Poder de Controle na Sociedade Anônimas. 4. ${ }^{a}$ edição. Rio de Janeiro: Forense, 2005, p. 70. 
conceito fluido, ou, adotando a terminologia adotada por Fernando Sainz Moreno ${ }^{333}$, influência dominante ou controladora é um conceito jurídico indeterminado, ou seja, o referido conceito possui o que aquele autor denomina de três zonas: zona de certeza positiva, zona de certeza negativa e zona cinzenta.

Dessa maneira, embora o conceito de influência dominante não seja preciso, mas, sim, um conceito fluido, este possui um conteúdo mínimo, proporcionando ao intérprete o conhecimento de uma zona de certeza positiva, quer dizer, o intérprete sabe o que pode ser qualificado como sendo influência dominante, bem como de uma zona de certeza negativa, isto é, o intérprete sabe o que não pode ser qualificado como sendo influência dominante ${ }^{334}$.

Todavia, ainda resta uma denominada zona cinzenta, que é aquela que apresenta uma grande dificuldade para se determinar e, por isso, exigirá um árduo trabalho interpretativo das circunstâncias fáticas diante das normas jurídicas, de forma que não se conseguirá atingir um conceito determinado e preciso de influência dominante.

Aliás, como bem aponta Celso Antônio Bandeira de Mello:

"É certo que todas as palavras têm um conteúdo mínimo, sem o que a comunicação humana seria impossível. Por isso, ainda quando recobrem noções elásticas, estão de todo modo circunscrevendo um campo de realidade suscetível de ser apreendido, exatamente porque recortável no universo das possibilidades lógicas, mesmo que em suas franjas remanesça alguma imprecisão.",335

Portanto, o conceito de influência dominante, se adotado pelo legislador no conceito legal de acionista controlador, estará fadado a ser um conceito fluido, elástico, não sendo jamais alcançado um conceito inteiramente determinado e preciso, permitindo,

\footnotetext{
${ }^{333}$ MORENO, Fernando Sainz. Conceptos Jurídicos, Interpretación y Discricionariedad Administrativa. 4. a edição. Madri: Civitas, 1976.

334 “(...) el de certeza positiva (lo que es seguro que es) y el de certeza negativa (lo que es seguro que no es)”. (Tradução livre: “(...) o de certeza positiva (o que é seguro que é) e de certeza negativa (o que é seguro que não é).") (Idem, ibidem, p. 70 -. 71)

335 MELlo, Celso Antônio Bandeira de. Curso de Direito Administrativo. 6. ${ }^{\text {a }}$ edição. São Paulo: Malheiros, 1995, p.489-490.
} 
justamente por isso, uma maior maleabilidade quanto às manifestações do exercício do poder de controle e assim permitindo uma maior e mais fácil adaptação do conceito de acionista controlador à realidade empresarial, que, frise-se novamente, é altamente mutável. 


\section{OS SISTEMAS DE CAPITAL CONCENTRADO E DISPERSO E O EXERCÍCIO DO PODER DE CONTROLE NA COMPANHIA DE CAPITAL ABERTO BRASILEIRA}

\section{OS SISTEMAS DE CAPITAL CONCENTRADO E DISPERSO}

Desde a publicação da obra A Moderna Sociedade Anônima e a Propriedade Privada, de autoria de Adolf Berle e Gardiner Means ${ }^{336}$, criou-se o dogma de que as macroempresas, na modalidade de sociedades por ações, tenderiam a buscar uma evolução, que seria atingida em seu grau máximo com a dispersão absoluta das ações e com a assunção do poder de controle pelos administradores da companhia, havendo verdadeira dissociação entre a propriedade privada das ações e o exercício do poder de controle no âmbito das companhias.

Segundo, ainda, Berle e Means, esta dissociação entre propriedade acionária e exercício do poder de controle seria possível em razão do novo conceito de propriedade produtiva, de modo que "em relação a isso, é preciso salientar a enorme ampliação do alcance do termo 'propriedade'. Ela não só está divorciada do poder de decisão de seus donos, seus supostos beneficiários (acionistas e congêneres), como chega a abranger uma série de conceitos sobrepostos ao núcleo que significa domínio sobre as coisas tangíveis." 337

Diante da propalada alteração do conceito de propriedade produtiva, a sociedade por ações tornar-se-ia a proprietária do capital, os acionistas seriam os usufrutuários dos ativos e os administradores seriam uma espécie de "truste" sem controle, de maneira que o poder de decisão não estaria mais vinculado à propriedade acionária,

\footnotetext{
${ }^{336}$ BERLE Jr., Adolf Augustus; MEANS, Gardiner C. A Moderna Sociedade Anônima e a Propriedade Privada. 3. ${ }^{a}$ edição. São Paulo: Nova Cultural, 1988.

${ }^{337}$ Idem, ibidem, p. 7.
} 
embora o sistema acionário seja considerado como sendo o principal fator de organização econômica, justamente por mobilizar interesses relativos à propriedade.

Na visão de Berle e Means, o sistema acionário apresentaria uma tendência à reunião de riquezas em empresas que formariam verdadeiros aglomerados, denotando o exercício de uma "força centrípeta", ao concentrar não só capital, mas também o poder econômico. Ao mesmo tempo, o sistema acionário atribuiria o exercício do poder de controle aos poucos administradores, isto porque o sistema acionário apresentaria uma tendência a atingir um alto grau de dispersão (exercício de uma "força centrífuga"), limitando-se, a propriedade acionária, a uma verdadeira propriedade usufrutuária ${ }^{338}$.

Assim, haveria uma correlação entre crescimento da empresa e dispersão da propriedade acionária, a qual, por sua vez, ter-se-ia transformado em mero título representativo e destituído de controle sobre a propriedade, tornando-se, os acionistas, em meros agentes passivos. Em contrapartida, os administradores passaram a deter o controle sobre a riqueza pessoal dos acionistas que, por sua vez, sujeitam-se de modo crescente às condições do mercado e não mais ao uso direto, pelo proprietário, do bem objeto da propriedade acionária.

Nesse sentido, Berle e Means concluem que "no sistema acionário, o 'proprietário' de riqueza industrial ficou apenas com um símbolo de propriedade, enquanto o poder, a responsabilidade e a substância que foram parte integrante da propriedade no passado estão sendo transferidos para um grupo independente em cujas mãos está o controle." 339

A partir do estudo desenvolvido por Adolf Berle e Gardiner Means, foram desenvolvidos inúmeros estudos ${ }^{340}$ acerca dos sistemas de propriedade acionária, os quais,

\footnotetext{
338 "Acompanhando a concentração do poder econômico, brotando dele e tornando-o possível, difundiu-se cada vez mais a propriedade de ações. Isso acarretou uma mudança fundamental ao caráter da riqueza - a relação entre o indivíduo e sua riqueza, o valor dessa riqueza e a natureza da própria propriedade. A dispersão da propriedade de empresas independentes parece inerente ao sistema acionário. Esse sistema já foi longe, está crescendo rapidamente e parece um processo inevitável." (BERLE Jr., Adolf Augustus; MEANS, Gardiner C. A Moderna Sociedade Anônima e a Propriedade Privada. 3. a edição. São Paulo: Nova Cultural, 1988, p. 69)

${ }^{339}$ Idem, ibidem, p. 83.

340 Vide, por exemplo: HANSMANN, Henry; KRAAKMAN, Renier. The End of History for Corporate Law. In: Georgetown Law Journal, $\mathrm{n}^{\circ} \quad 89, \quad 2001 . \quad$ Disponível em: <http://papers.ssrn.com/sol3/papers.cfm?abstract_id=204528>. Acesso em 29.07.2012; GILSON, Ronald J.,
} 
em breve síntese, chegaram a relacionar o sistema de capital disperso ao sistema legal da common law e, por outro lado, o sistema de capital concentrado ao sistema legal da civil law.

Ademais, referidos estudos preconizaram a superioridade do sistema de capital disperso em relação ao sistema de capital concentrado, afirmando, inclusive, que aquele sistema havia-se tornado um modelo padrão, ao qual os demais sistemas iriam convergir, especialmente porque o Direito Societário já havia apresentado uma uniformidade, cuja convergência tendia ao modelo padrão (sistema de capital disperso).

Nesse sentido, afirmam Henry Hansmann e Reinier Kraakman:

"Recente estudo enfatizou a existência de diferenças institucionais em governança, propriedade acionária, mercado de capitais e cultura negocial entre companhias Europeias, Americanas e Japonesas. Apesar desta aparente divergência, entretanto, a legislação básica de governança societária - de fato, maioria do direito societário - atingiu um alto grau de uniformidade nestas jurisdições e continuam convergindo em direção a um único modelo padrão o que parece provável." ${ }^{341}$ (tradução livre)

Segundo Henry Hansmann e Reinier Kraakmen, o insucesso dos modelos associado às pressões competitivas do comércio internacional com maior fluxo de capitais e de transações mercantis, especialmente tendentes a uma convergência dos institutos em um mundo globalizado, com a tendência para a formação de um "direito unitário", justamente com o fim de criar ambientes homogêneos e, portanto, facilitadores do fluxo de capitais, teriam levado à concepção da convergência para o sistema de capital disperso em detrimento dos outros modelos de direito societário, que, ao que parecia, seria o sistema de

Globalizing Corporate Governance: Convergence of Form or Function. In: American Journal of $\begin{array}{llllll}\text { Comparative Law, } & \mathrm{n}^{\circ} & 49, & 2001 . & \text { Disponível } & \mathrm{em}\end{array}$ <http://papers.ssrn.com/sol3/papers.cfm?abstract_id=229517>. Acesso em 29.07.2012.

341 "Recent scholarship has emphasized institutional differences in governance, share ownership, capital markets, and business culture among European, American, and Japanese companies. 1 Despite this apparent divergence, however, the basic law of corporate governance -- indeed, most of corporate law -- has achieved a high degree of uniformity across these jurisdictions, and continuing convergence toward a single standard model is likely." (HANSMANN, Henry; KRAAKMAN, Renier. The End of History for Corporate Law. In: Georgetown Law Journal, $\mathrm{n}^{\mathrm{o}} \quad 89, \quad 2001, \quad$ p. $1 . \quad$ Disponível em: <http://papers.ssrn.com/sol3/papers.cfm?abstract_id=204528>. Acesso em 29.07.2012) 
direito societário mais eficiente e, por isso, deveria tornar-se um modelo padrão em contraposição ao modelo de capital concentrado, o que, inclusive, levou juristas a preconizarem que teria havido o fim da história do direito societário com o suposto fracasso dos modelos de direito societário, que teriam sido sobrepujados pelo modelo mais eficiente baseado na dispersão acionária.

Nesse sentido, Henry Hansmann e Reinier Kraarkman afirmaram:

"Debate e experimentação relativos à estrutura básica do direito societário durante o século XX centraram-se nas formas em que aquela legislação deveria acomodar os interesses dos grupos de não-acionistas. A este respeito, três alternativas principais ao modelo direcionado ao acionista eram o foco tradicional da atenção. Nós denominamos aquelas alternativas como modelos de direito societário direcionados ao administrador, aos empregados e ao Estado. Embora cada um daqueles modelos alternativos tenham - em diversos pontos e em várias jurisdições - atingido algum sucesso tanto na prática quanto em opinião aceita, todos os três perderam ultimamente muito de seu apelo normativo.

A literatura acadêmica recente focou no modelo de direito direcionado ao investidor como principal alternativa ao modelo direcionado ao acionista. $O$ modelo direcionado ao investidor, entretanto, é essencialmente uma combinação de elementos encontrados no antigo modelo direcionado ao administrador e do modelo direcionado ao trabalhador. Consequentemente, as mesmas forças que foram desacreditando estes últimos modelos estão também solapando o modelo direcionado ao investidor como alternativa viável ao modelo direcionado ao acionista." 342

\footnotetext{
342 "Debate and experimentation concerning the basic structure of corporate law during the twentieth century centered on the ways in which that law should accommodate the interests of non-shareholder constituencies. In this regard, three principal alternatives to a shareholder-oriented model were the traditional foci of attention. We term these the manager-oriented, the labor-oriented, and the state-oriented models of corporate law. Although each of these three alternative models has -- at various points and in
} 
Todavia, estudos mais recentes e baseados em dados empíricos demonstram que a presumida superioridade do sistema legal da common law não se sustenta, tratandose de uma simplificação grosseira, pois há diversos fatores que influenciam a adoção de um sistema (de capital concentrado ou disperso) e a obtenção de seu maior grau de eficácia, não se limitando ao sistema legal, o qual é apenas um dos fatores influenciadores, mas não o único, tampouco o principal deles.

A propósito, esta é a conclusão de John C. Coffee Jr.:

“Um exame mais próximo da tabela antecedente também sugere que a suposta superioridade da common law em relação a civil law representa uma simplificação grosseira." ${ }^{343}$ (tradução livre)

Assim, tais estudos indicam que a dispersão do capital não é o caminho natural de toda grande companhia que atingiria seu grau máximo de evolução, mas, sim, consequência direta da atividade legislativa e da atividade regulatória, que, por exigir o cumprimento de inúmeras obrigações de informar os entes regulatórios e governamentais, sempre que o acionista atinja certa participação no capital social por meio de ações com direito a voto, induzem os acionistas a evitar a concentração acionária e, consequentemente, as companhias apresentam uma grande dispersão acionária.

Segundo Gerald F. Davis e Tracy A. Thompson, “o surgimento do ativismo dos acionistas nos Estados Unidos forçou uma revisão das origens da corporação gerencial. Recentemente, estudiosos jurídicos forneceram argumentos persuasivos no sentido de que a separação inicial da propriedade e controle não era a consequência

various jurisdictions -- achieved some success both in practice and in received opinion, all three have ultimately lost much of their normative appeal.

Recent academic literature has focused on the stakeholder model of the corporation as the principal alternative to the shareholder-oriented model. The stakeholder model, however, is essentially just a combination of elements found in the older manager-oriented and labor-oriented models. Consequently, the same forces that have been discrediting the latter models are also undermining the stakeholder model as a viable alternative to the shareholder-oriented model." (HANSMANN, Henry; KRAAKMAN, Renier. The End of History for Corporate Law. In: Georgetown Law Journal, nº 89, 2001, p. 3 e p. 4. Disponível em: <http://papers.ssrn.com/sol3/papers.cfm?abstract_id=204528>. Acesso em 29.07.2012)

343 "A closer examination of the foregoing table also suggests that the assumed superiority of common law to civil law represents a gross oversimplification." (COFFEE Jr., John C. Do Norms Matter?: A CrossCountry Examination of the Private Benefits of Control. In: Columbia Lawand Economics Working Paper, n. ${ }^{\circ}$ 183, 2001, p. 15. Disponível em <http://papers.ssrn.com/sol3/papers.cfm?abstract_id=257613>. Acesso em 08.06.2014) 
inevitável da empresa de larga escala, como retratado por Berle e Means, mas o resultado de restrições legais e regulatórias que originaram pressões políticas populistas e foram sustentadas pela influência política dos administradores corporativos (Roe, 1991). O controle gerencial dentro da empresa depende de normas criadas externamente pelos governos estadual e federal, e a alocação do controle corporativo, assim, depende das lutas políticas entre os administradores, capital e diversos órgãos governamentais." $" 344$ (tradução livre)

A propósito, como já visto quando do estudo de Direito Comparado feito anteriormente, no Direito Norte-americano, por exemplo, o Delaware General Corporation Law, no item n. ${ }^{\circ}$, da alínea “c”, do $§ 203$, do Subcapítulo VI, do Capítulo 1, do Título 8, presume que um acionista seja controlador quando detiver $20 \%$ (vinte por cento) ou mais dos valores mobiliários em circulação com direito de voto, sem se considerar que a mera detenção de participação superior a $5 \%$ (cinco por cento) impõe ao acionista o dever de fornecer diversas informações por meio de formulários. Além disso, o Direito Norte-americano aplica as mesmas regras aplicáveis ao insider trading a todos os acionistas que possuírem uma participação igual ou superior a $10 \%$.

O mesmo pode ser observado no Direito Comunitário Europeu, no qual a Diretiva 88/627/CEE do Conselho, de 12.12.1988, pretendendo que os Estados Membros adotem uma política adequada de informação aos investidores, com a finalidade de não só conferir uma maior proteção aos investidores, mas também reforçar a confiança nos mercados de valores mobiliários e assegurar seu bom funcionamento, de modo a formar um mercado europeu de valores mobiliários, impõe o dever de fornecer e publicar informações sempre que houver a aquisição ou alienação de uma participação relevante em sociedades cotadas em bolsa.

\footnotetext{
344 "The rise of shareholder activism in the U.S. has forced a reassessment of the origins of the managerialist corporation. Recently, legal scholars have provided compelling arguments that the initial separation of ownership and control was not the inevitable consequence of large-scale enterprise, as portrayed by Berle and Means, but resulted from legal and regulatory constraints that originated in populist political pressures and were sustained by politically influential corporate managers (Roe, 1991 ). Management's control within the firm is contingent on rules determined externally by state and federal governments, and the allocation of corporate control thus depends on political struggles among management, capital, and various governmental bodies." (DAVIS, Gerald F.; THOMPSON, Tracy A.. A Social Movement Perspective on Corporate Control. In: Administrative Science Quarterly, v. 39, $\mathrm{n}^{\circ} 1,1994$, p. 141. Disponível em < http://webuser.bus.umich.edu/gfdavis/Papers/A\%20Social\%20Movement.pdf>. Acesso em 09.06.2013)
} 
Para tanto, o Artigo $4^{\circ}$ da supra mencionada Diretiva considera participação relevante aquela alienação ou aquisição que permitir a detenção de pelo menos $10 \%$ (dez por cento) de valores mobiliários com direito de voto, o que imporá a obrigação de informar não só a sociedade, mas também as autoridades competentes.

O Direito Francês, por sua vez, também apresenta o dever de informar no Artigo L233-7, inciso I, do Código Comercial $^{345}$, sempre que um acionista detiver ações com direito de voto igual ou superior a $5 \%$ (cinco por cento) em sociedade por ações com cotação em bolsa, conforme legislação do Conselho de Estado da França. Observe-se que este dever de informar deve ser cumprido não só perante a sociedade, mas também à Autoridade dos Mercados Financeiros (Artigo L233-7, inciso II, do Código Comercial Francês ${ }^{346}$ ), sem prejuízo do próprio estatuto social poder impor ao acionista uma obrigação complementar de informação, quando tiver uma participação inferior a 5\%, mas desde que não seja inferior a $0,5 \%$ (cinquenta centésimos por cento) do capital ou de

345 “Article L233-7

I.-Lorsque les actions d'une société ayant son siège sur le territoire de la République sont admises aux négociations sur un marché réglementé d'un Etat partie à l'accord sur l'Espace économique européen ou sur un marché d'instruments financiers admettant aux négociations des actions (...), toute personne physique ou morale agissant seule ou de concert qui vient à posséder un nombre d'actions représentant plus du vingtième, du dixième, des trois vingtièmes, du cinquième, du quart, des trois dixièmes, du tiers, de la moitié, des deux tiers, des dix-huit vingtièmes ou des dix-neuf vingtièmes du capital ou des droits de vote informe la société dans un délai fixé par décret en Conseil d'Etat, à compter du franchissement du seuil de participation, du nombre total d'actions ou de droits de vote qu'elle possède." (Tradução livre: "Artigo L2337 I - Quando as ações de uma sociedade com sede no território da República são admitidas a negociações no mercado regulamentado de um Estado parte do acordo sobre o Espaço econômico europeu ou em um mercado de instrumentos financeiros admitidos a negociações de ações (...), todas as pessoas físicas ou morais que ajam sozinhas ou em concerto, que venham a possuir um número de ações representante de mais de 1/20, 1/10,3/20, 1/5, 1/4,3/10, 1/3, 1/2, 2/3, 18/20 ou 19/20 do capital ou dos direitos de voto, informarão a sociedade dentro de um prazo fixado por decreto do Conselho de Estado, a computar a passagem de sua participação, o número total de ações ou os direitos de voto que elas possuem.") (Disponível em <http://www.legifrance.gouv.fr/affichCode.do;jsessionid=58086CD4BD27723D00CCA8460E177646.tpdjo1 4v_1 cidTexte=LEGITEXT000005634379\&dateTexte=20140330>. Acesso em 30.03.2014.)

346 “Article L233-7

(...)

II.- La personne tenue à l'information mentionnée au I informe également l'Autorité des marchés financiers, dans un délai et selon des modalités fixés par son règlement général, (...) Cette information est portée à la connaissance du public dans les conditions fixées par le règlement général de l'Autorité des marchés financiers." (Tradução livre: "Artigo L233-7 (...) II.-A pessoa que se tiver a informação mencionada no inciso I, informará igualmente a Autoridade dos mercados financeiros, dentro de um prazo e de acordo com as modalidades fixadas pelo regulamento geral (...) Esta informação será levada ao conhecimento do público dentro das condições fixadas pelo regulamento geral da Autoridade dos mercados financeiros.") (Disponível 
valores mobiliários com direito de voto (Artigo L233-7, inciso III, do Código Comercial Francês ${ }^{347}$ ).

Dessa forma, o pensamento jurídico, ainda conforme Gerald F. David e Tracy A. Thompson, encontra-se em transição, e atualmente acredita-se que a estrutura do poder de controle da grande companhia com capital aberto reflete mais uma adaptação política, não só às normas produzidas pelos entes estatais (incluindo órgãos reguladores), mas também à formação de coalizões internas na companhia para agregar interesses comuns e, assim, interagir com o Estado e, igualmente, sofrer influência do Estado, afastando-se, desse modo, do pensamento tendente a acreditar que o poder de controle nas companhias de capital aberto seria uma consequência imediata da busca pela eficiência associada com a Teoria da Agência ${ }^{348}$.

Portanto, a organização interna do poder de controle deixa de ser uma mera consequência do processo evolutivo da grande companhia e da busca por uma estrutura organizacional que sirva melhor e mais eficientemente os interesses dos acionistas, mas decorrência da luta interna pelo poder de controle e da interação entre companhia e Estado $^{349}$, sendo a dispersão acionária mera consequência das normas estatais e regulatórias $^{350}$.

347 “Article L233-7

(...)

III.- Les statuts de la société peuvent prévoir une obligation supplémentaire d'information portant sur la détention de fractions du capital ou des droits de vote inférieures à celle du vingtième mentionnée au I.L'obligation porte sur la détention de chacune de ces fractions, qui ne peuvent être inférieures à $0,5 \% d u$ capital ou des droits de vote." (Tradução livre: “Artigo L233-7 (...) III.-O estatuto da sociedade pode prever uma obrigação suplementar de informação contendo a detenção de frações do capital ou dos direitos de voto inferiores àquela de 1/20 mencionada no inciso I. A obrigação que versa sobre a detenção de cada uma dessas frações, não pode considerar frações inferiores a 0,5\% do capital ou dos direitos de voto.") (Disponível <http://www.legifrance.gouv.fr/affichCode.do;jsessionid=58086CD4BD27723D00CCA8460E177646.tpdjo1 4v_1 ?cidTexte=LEGITEXT000005634379\&dateTexte=20140330 >. Acesso em 30.03.2014.)

${ }^{348}$ Segundo Érica Gorga, a teoria da agência ou a relação de agência consiste no "contrato pelo qual uma pessoa ou grupo de pessoas, considerados principais, delegam poder de decisão para uma ou mais pessoas, os agentes, realizarem serviços em benefício dos primeiros." (GORGA, Érica. Direito Societário Atual. Rio de Janeiro: Elsevier, 2013, p. 53)

349 "The core insight of agency theory-that shareholders and managers have conflicting interests and that corporate structures embody efforts to deal with this inherent conflict-is essential for understanding the evolution of the modern corporation. But several major features of American corporations are more parsimoniously explained as outcomes of political struggles than as adaptations designed to serve the best interests of shareholders." (Tradução livre: "O conhecimento do núcleo da teoria da agência - que acionistas e administradores possuem interesses conflitantes e que as estruturas corporativas incorporam esforços para lidar com estes conflitos inerentes - é essencial para compreender a evolução da corporação 
Ademais, há estudos ${ }^{351}$ que indicam que o sistema de capital disperso com companhias nos moldes desenhados por Berle e Means não é o mais utilizado, tal como se imaginava anteriormente, ao contrário, parece ser mais utilizado o sistema de capital concentrado, o que confronta diretamente com o pensamento que prega a superioridade do sistema de capital disperso em relação ao sistema de capital concentrado.

A propósito, conforme relato de Marco Becht e Colin Mayer, na Europa Continental, há uma grande concentração acionária, visto que o controlador majoritário, via de regra, detém uma participação igual ou superior a $50 \%$ (cinquenta por cento) das ações votantes, enquanto que no Reino Unido, o controlador detém na média 10\% (dez por cento) e nos Estados Unidos, $6 \%$ (seis por cento), in verbis:

"Este estudo relata resultados de um estudo internacional destes dados por membros da Rede Europeia de Governança Corporativa. Esta registra altos níveis de concentração do controle de companhias em muitos países Europeus com único detentor de bloco de ações frequentemente controlando mais de $50 \%$ dos votos. Em contraste, a maioria das companhias listadas no Reino Unido não possui detentor de bloco de ações superior a 10\% das ações e a maioria das companhias

moderna. Mas diversas características das corporações Americanas são indesejadamente mais explicadas como resultados de lutas políticas do que adaptações projetadas para servir o melhor interesse dos acionistas.") (DAVIS, Gerald F.; THOMPSON, Tracy A.. A Social Movement Perspective on Corporate Control. In: Administrative Science Quarterly, v. 39, $\mathrm{n}^{\circ}$ 1, 1994, p. 146. Disponível em < http://webuser.bus.umich.edu/gfdavis/Papers/A\%20Social\%20Movement.pdf >. Acesso em 09.06.2013)

${ }_{350}$ "Yet recent reinterpretations of the historical record concur that politics-and not just economicsseparated ownership and control in American corporations." (Tradução livre: "Ainda reinterpretações recentes dos dados históricos concordam que a política - e não apenas economia - separou a propriedade e o controle nas corporações Americanas.")(DAVIS, Gerald F.; THOMPSON, Tracy A.. A Social Movement

Perspective on Corporate Control. In: Administrative Science Quarterly, v. 39, $\mathrm{n}^{\text {o }}$ 1, 1994, p. 147. Disponível em < http://webuser.bus.umich.edu/gfdavis/Papers/A\%20Social\%20Movement.pdf>. Acesso em 09.06.2013)

${ }^{351}$ Vide LA PORTA, Rafael; LOPEZ-DE-SILANES, Florencio; SHLEIFER, Andrei. Corporate Ownership Around the World. In: The Journal of Finance, v. 54, 1999. Disponível em < http://papers.ssrn.com/sol3/papers.cfm?abstract_id=103130>. Acesso em 29.07.2012; LA PORTA, Rafael; LOPEZ-DE-SILANES, Florencio; SHLEIFER, Andrei; VISHNY, Robert W. Legal Determinants of External Finance. In: The Journal of Finance, v. 52, 1997. Disponível em <http://papers.ssrn.com/sol3/papers.cfm?abstract_id=8179>. Acesso em 29.07.2012. 
listadas nos Estados Unidos não possui detentor de bloco com mais de 6\% das ações." ${ }^{, 352}$ (tradução livre)

Ademais, um movimento social recente, que foi constatado por Gerald F. Davis e Tracy A. Thompson ${ }^{353}$, apresenta uma tendência de concentração da titularidade das ações por investidores institucionais, que, justamente por concentrarem a titularidade de ações em favor dos titulares de quotas de, por exemplo, fundos de pensão, passaram a pregar também um maior ativismo dos acionistas e um exercício mais efetivo do direito de voto.

Gerald F. Davis e Tracy A Thompson ${ }^{354}$ relatam que a participação do investidor institucional aumentou de $15,8 \%$ (quinze inteiros e oitenta centésimos por cento)

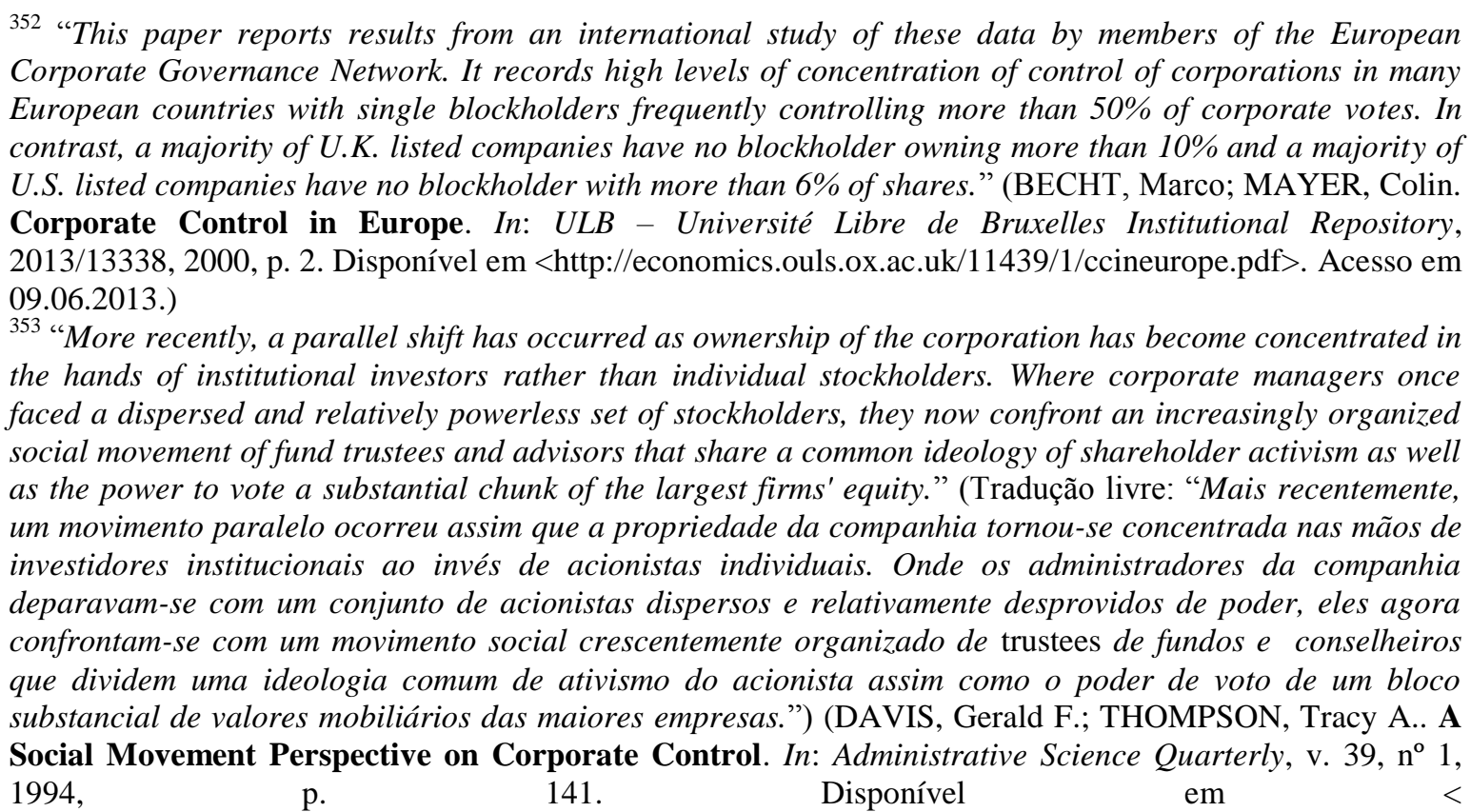

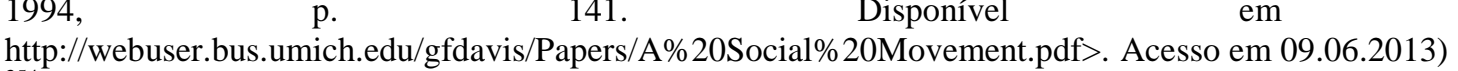

354 "The proportion of the average firm's equity controlled by institutional investors has increased substantially in the past three decades, from 15.8 percent in 1965 to 42.7 percent in 1986 (Useem, 1993). This trend has been even more pronounced among the largest firms, where over 50 percent of the average firm's common shares are held by institutions. While institutional investors are a broad category that includes banks, insurance companies, investment companies, and others, pension funds are among the largest. In 1960, pension funds held a 4-percent stake in the Standard and Poor's 500; in 1970 it was 9.4 percent; and by 1988 it had increased to 23.2 percent (...) Thus, there has been an ongoing trend in which large firms are increasingly owned by institutions, rather than individuals, and by a relatively small number of pension funds in particular. This trend shows every sign of continuing into the future." (Tradução livre: " $A$ proporção media dos valores mobiliários controlados por investidores institucionais aumentou substancialmente nas últimas três décadas, de 15,8\% em 1965 para 42,7\% em 1986 (Useem, 1993). Esta tendência foi ainda mais pronunciada entre as grandes empresas, nas quais em média mais de $50 \%$ das ações ordinárias são detidas pelas instituições. Enquanto os investidores institucionais são uma grande categoria que inclui bancos, companhias seguradoras, companhias de investimento e outros, fundos de pensão estão dentre os maiores. Em 1960, os fundos de pensão detinham uma participação de 4\% segundo 
em 1965 para 42,7\% (quarenta e dois inteiros e setenta centésimos por cento) em 1986, denotando uma tendência à concentração acionária em grandes empresas, concentração esta liderada por investidores institucionais em detrimento de investidores individuais, em especial por fundos.

Logo, pode-se, desde já, constatar dos estudos realizados que não há que se falar em superioridade do sistema legal da common law em relação ao sistema legal da civil law, tampouco em superioridade do sistema de capital disperso em relação ao sistema de capital concentrado, além do atingimento da dispersão acionária não ser o grau máximo de evolução das macrocompanhias.

Ademais, com o passar do tempo e embora tenha havido no mundo uma convergência econômica e cultural relativa, constatou-se que nem sempre havia a efetiva mudança das instituições e normas para permitir a adoção plena do suposto modelo padrão, mas, sim, havia a persistência de sistemas de direito societário distintos, sem prejuízo da tendência de concentração acionária em investidores institucionais.

Tal persistência devia-se à dependência histórica estrutural, aos custos irrecuperáveis para a adaptação ao novo modelo, à não adaptação das atividades complementares desenvolvidas no entorno da empresa, ao tempo e ao custo investidos nas atividades de entorno, bem como à possibilidade de haver múltiplos sistemas eficientes, o que incentivou a permanência da divergência de sistemas de direito societário. Diante daqueles fatores de resistência, passou-se a ter apenas adaptações dos sistemas de direito societário vigentes, que permitiam uma aproximação aos aspectos mais relevantes e melhores do modelo de capital disperso, respeitando-se a dependência do ambiente institucional e a falta de flexibilidade para a mudança integral.

Dessa forma, passou-se a considerar que o melhor seria adotar um modelo voltado à proteção e ao respeito dos diversos interesses envolvidos nas sociedades por ações, quais sejam, os interesses dos acionistas, dos diretores, dos administradores, dos

Standard and Poor's 500; em 1970 detinham 9,4\%; e por volta de 1988 houve um aumento para 23,2\% (...) Assim, tem havido uma tendência atual em que as grandes empresas são crescentemente detidas por instituições em detrimento de indivíduos e por um número relativamente pequeno de fundos em especial.")(DAVIS, Gerald F.; THOMPSON, Tracy A.. A Social Movement Perspective on Corporate Control. In: Administrative Science Quarterly, v. 39, $\mathrm{n}^{\circ}$ 1, 1994, p. 154. Disponível em < http://webuser.bus.umich.edu/gfdavis/Papers/A\%20Social\%20Movement.pdf>. Acesso em 09.06.2013) 
fornecedores, dos empregados e da comunidade em que atua a sociedade, sem, contudo, implicar na alteração do modelo societário adotado.

Assim, como forma de aproximação aos aspectos mais interessantes e melhores do sistema de direito societário de capital disperso, verificou-se que os países adotaram estratégias de convergência distintas para tanto.

Alguns optaram pela convergência funcional, isto é, adotaram institutos flexíveis e hábeis para responder às mudanças no mercado de capitais, sem alterar as características formais das instituições. Outros países adotaram a convergência formal, que consiste na efetiva alteração da legislação para modificar a estrutura básica das instituições existentes, enquanto outros adotaram a convergência contratual, visto que as instituições não possuem flexibilidade para responder às mudanças formais e as barreiras políticas, por sua vez, restringem a capacidade formal de mudança, não restando alternativa senão a via contratual para a convergência.

Segundo estudo de Ronald J. Gilson, embora tenha conseguido identificar três modelos básicos de convergência, pode-se concluir apenas que há uma grande variedade de estratégias adotadas nos diversos países em termos de aproximação dos sistemas de direito societário, in verbis:

"Neste artigo, eu pesquisei três tipos de convergência de governança corporativa: convergência funcional, quando as instituições de governança são flexíveis o suficiente para responder a demandas de mudanças circunstanciais sem alterar as características formais das instituições; convergência formal, quando uma resposta efetiva requer uma ação legislativa para alterar a estrutura básica existente de instituições de governança; e convergência contratual, aonde a resposta assume a forma de contrato, pois as instituições de governança existentes carecem de flexibilidade para responder sem mudança formal, e barreiras políticas restringem a capacidade para mudança institucional formal. Adicionalmente, duas formas de convergência híbrida envolvendo seleção voluntária de diferentes regras formais oferecidas por outras jurisdições ambas dentro e sem a União Europeia 
foram consideradas. A diversidade de circunstâncias sugere que não pode haver uma previsão geral do modo que assumirá a convergência de instituições nacionais de governança corporativa. Pois a flexibilidade das instituições de governança e políticas diferirão não apenas entre países, mas dentro de países considerados individualmente baseado na resposta particular demandada pela mudança de condições, o máximo que nós podemos prever é uma variação substancial ambas através e dentro de sistemas nacionais distintos, o que Stephen J. Gould chamou 'uma engenhoca não uma amável invenção'., 355

Por fim, passa a ser mais assente na doutrina que a opção pela adoção do sistema de capital disperso ou sistema de capital concentrado é influenciada por diversos fatores, não se limitando somente à busca de um sistema eficiente em termos de satisfação dos interesses dos acionistas, às disputas políticas internas pela obtenção do poder de controle e/ou à interação da companhia com o ambiente político estatal.

Segundo Érica Gorga ${ }^{356}$, a opção por um sistema é influenciada diretamente pelos ambientes institucional e societário, pela conduta dos agentes econômicos, pelo papel do direito, pelas normas autorregulatórias, pelas normas sociais vigentes, pela dependência da trajetória e da política no desenvolvimento do mercado de capitais.

\footnotetext{
355 "In this essay, I have surveyed three kinds of corporate governance convergence: functional convergence, when existing governance institutions are flexible enough to respond to the demands of changed circumstances without altering the institutions' formal characteristics; formal convergence, when an effective response requires legislative action to alter the basic structure of existing governance institutions; and contractual convergence, where the response takes the form of contract because existing governance institutions lack the flexibility to respond without formal change, and political barriers restrict the capacity for formal institutional change. Additionally, two forms of hybrid convergence, involving voluntary selection of different formal rules offered by other jurisdictions both within and without the European Union, were considered. The diversity of circumstances suggests that there can be no general prediction of the mode that convergence of national corporate governance institutions may take. Because the flexibility of governance and political institutions will differ not only between countries, but within individual countries based on the particular response called for by changed conditions, the most we can predict is substantial variation both across and within different national systems, what Stephen J. Gould called "a contraption not a lovely contrivance."' (GILSON. Ronald J.. Globalizing Corporate Governance: Convergence of Form or Function. In: American Journal of Comparative Law, $\mathrm{n}^{\circ}$ 49, 2001. Disponível em < http://papers.ssrn.com/sol3/papers.cfm?abstract_id=229517>. Acesso em 29.07.2012)

356 "O estudo empreendido analisou características do ambiente institucional e societário, contribuindo para maior compreensão dos incentivos que influenciam a conduta dos agentes econômicos, bem como do papel do Direito, das normas criadas por agentes privados, das normas sociais, da dependência de trajetória e da política no desenvolvimento do mercado de capitais." (GORGA, Érica. Direito Societário Atual. Rio de Janeiro: Elsevier, 2013, p. 129)
} 
Nesse sentido foi o estudo feito por Mark Roe ${ }^{357}$, segundo o qual escolha pela adoção de certo sistema e sua persistência no curso do tempo dependem substancialmente da coalização de interesses não só entre os detentores do capital, mas também entre os não detentores de capital, coalização esta que influenciará os resultados da política econômica estatal e, consequentemente, afetará o resultado legislativo no âmbito societário e no âmbito do mercado de valores mobiliários, resultando, desse modo, em um mercado de capitais mais desenvolvido ou não conforme a coalizão de interesses prevalecente.

Com efeito, o funcionamento do mercado de capitais depende muito do suporte que será dado pelas instituições políticas, ou seja, a política econômica adotada influenciará muito o formato e a extensão do mercado de capitais, não se tratando de uma influência formada pelas capacidades das instituições políticas, mas, sim, dos interesses que prevalecerão em razão das coalizões de interesses formadas e prevalecentes.

Isto quer dizer, segundo Mark Roe, que o modelo de direito societário adotado e, consequentemente, a forma do mercado de capitais (e do próprio mercado financeiro como um todo) dependerá da política econômica adotada, o que será resultado da coalizão de interesses prevalecente em dado país aliado às peculiaridades locais.

Assim, o mercado de capitais é extremamente influenciado pelos diversos interesses existentes, os quais muitas vezes são conflitantes, como, por exemplo, os interesses dos detentores de capital que pretendem influenciar as instituições econômicopolíticas a adotar uma tendência favorável ao mercado, os interesses das instituições financeiras, que visam à manutenção do financiamento bancário às empresas em oposição ao financiamento via mercado de capitais, os interesses dos acionistas controladores e mais recentemente dos investidores institucionais que pretendem preservar seus benefícios etc.

Contudo, o desenvolvimento do mercado de capitais não depende apenas do desenvolvimento e do aprimoramento das normas de direito societário, das normas reguladoras dos valores mobiliários, do Poder Judiciário e de outras instituições, mas,

357 ROE, Mark J.. Capital Markets and Financial Politics: Preferences and Institutions. In: Oxford Handbook on Capitalism, 2011. 2 Disponível r http://papers.ssrn.com/sol3/papers.cfm?abstract_id=1723331>. Acesso em 20.05.2014. 
sobretudo, da capacidade de formar coalizões de interesses que, por sua vez, influenciarão a política econômica e consequentemente a forma do mercado de capitais e de próprio mercado financeiro como um todo, o que pressupõe a existência de estabilidade política e de estabilidade social especialmente em mercados em desenvolvimento, conforme apontou Mark J. Roe:

"Autoridades em mercados em desenvolvimento usualmente focam no reforço de instituições que promovem o mercado financeiro, na crença de que um mercado financeiro melhor liderará o desenvolvimento econômico. Elas procuram desenvolver normas superiores de direito societário, melhores leis que regulam os valores mobiliários e melhorar o Poder Judiciário e outras instituições para cumprir contratos financeiros e outros. Estes esforços são apropriados, mas as condições historicamente necessárias para o mercado financeiro têm sido simples, com condições centrais de política econômica. Se a nação em desenvolvimento é suficientemente estável politicamente e socialmente, os primeiros passos para instituições do mercado financeiro podem ser tomadas, e geralmente têm sido tomadas, como ação governamental limitada. Depois disso, assim que o mercado financeiro desenvolver-se haverá interesses que visam a institucionalizar aquele desenvolvimento e levá-lo ao próximo nível - e quem tiver o know-how de fazê-lo." „358 (tradução livre)

O estudo de Mark Roe acima citado encontra ressonância em Gerald F. Davis e Tracy A. Thompson, segundo os quais "o poder de controle da companhia é

\footnotetext{
358 "Development authorities often focus on bolstering institutions that promote financial markets, in the belief that better financial markets will lead to economic development. They seek to develop superior corporate laws, better securities laws, and better courts and other institutions to enforce financial and other contracts. These efforts are appropriate, but the initial conditions needed historically for financial markets have been simple, with political economy conditions central. If the developing nation is sufficiently stable politically and socially, the first steps for financial markets institutions can be taken, and often have been taken, with limited government action. Thereafter, as the financial markets develop, there will be interests that seek to institutionalize that development and push it to the next level - and who have the know-how to do so." (ROE, Mark J.. Capital Markets and Financial Politics: Preferences and Institutions. In: Oxford Handbook on Capitalism, 2011, p. $8 . \quad$ Disponível em: <
} http://papers.ssrn.com/sol3/papers.cfm?abstract_id=1723331>. Acesso em 20.05.2014) 
inerentemente político e a política é realizada por coalizões de atores mutuamente familiarizados que reconhecem ou constroem um interesse comum." ${ }^{359}$ (tradução livre)

Desse modo, ainda de acordo com Mark J. Roe, os conflitos dos diversos interesses e, especialmente, os conflitos fundamentais entre detentores do capital (que podem capturar as instituições políticas para que a redistribuição da renda seja feita entre os próprios detentores de capital) e não detentores de capital (que podem decidir por não poupar e, assim, não gerar capital), bem como entre os próprios detentores de capital que capturam as instituições políticas (e, por isso, influenciam no resultado da política econômica ao obterem normas favoráveis a seus interesses e propiciadoras da manutenção de sua posição) e aqueles não as capturam, influenciam diversas dimensões da economia de um país, cujo problema político reside em encontrar instituições e interesses que mantenham tais conflitos e os custos deles decorrentes baixos, como ressaltou Mark J. Roe:

"Estes dois problemas surgem em múltiplas dimensões na economia, afetando pagamentos sociais e de bem-estar, política antitruste, tributação, direito societário, distribuição de renda e mercado financeiro. Muitos problemas aparentemente menores na implementação de regras e leis são manifestações locais de um desses dois problemas. ${ }^{360}$ (tradução livre)

Decorre dos estudos acima indicados que a política econômica aplicada ao mercado de capitais é decorrência da interação entre os interesses e preferências das pessoas que criam, modificam ou extinguem as instituições político-econômicas, bem

\footnotetext{
359 "Corporate control is inherently political, and politics is accomplished by coalitions of mutually acquainted actors that recognize or construct a common interest." (DAVIS, Gerald F.; THOMPSON, Tracy A.. A Social Movement Perspective on Corporate Control. In: Administrative Science Quarterly, v. 39, $\mathrm{n}^{\circ}$ 1, 1994, $\quad$ p. $152 . \quad$ Disponível em http://webuser.bus.umich.edu/gfdavis/Papers/A\%20Social\%20Movement.pdf>. Acesso em 09.06.2013)

360 "These two problems arise in multiple dimensions in the economy, affecting welfare and social payments, antitrust policy, taxation, corporate law, income distribution, and financial markets. Many seemingly smaller problems in implementation of rules and laws are local manifestations of one of these two problems. I have for the most part analyzed these two basic problems in the politics of capitalism in terms of how they specifically affect financial markets and corporate structures. The issues may be more general." (ROE, Mark J.. Capital Markets and Financial Politics: Preferences and Institutions. In: Oxford Handbook on Capitalism, 2011, p. 27. Disponível em: < http://papers.ssrn.com/sol3/papers.cfm?abstract_id=1723331>. Acesso em 20.05.2014)
} 
como da interação entre os interesses favoráveis e contrários ao desenvolvimento do mercado de capitais.

Assim, não só parece inexistir um modelo de direito societário vencedor, ao contrário do que era preconizado pela doutrina há pouco tempo, mas também parece haver uma combinação de técnicas para inserir em cada sistema, os elementos que são mais bem valorados pelo mercado e em conformidade com os interesses prevalecentes, sem que haja, todavia, a efetiva alteração do sistema, tampouco uma efetiva convergência a dado modelo de direito societário, uma vez que não se verificou nos estudos mais recentes a existência de uma efetiva convergência para o sistema de capital diluído, que, como já dito anteriormente, é pouco utilizado no mundo.

Ou seja, ao invés de mudar o sistema vigente com todas as implicações e custos inerentes à adaptação à mudança de sistema, os países apresentam uma tendência em manter seus sistemas tradicionais, adotando certas adaptações vistas como positivas para proporcionar o desenvolvimento do mercado de capitais, que, hoje, é visto como uma forma de financiamento privado menos custosa à companhia.

Além disso, o sistema de capital concentrado não é menos eficiente que o sistema de capital disperso, isto é, não há uma superioridade entre os sistemas, os quais podem ser mais ou menos eficientes conforme as condições locais (fatores políticos, culturais, normativos, judiciais, coalizões de interesses etc.).

Assim, visto que a adoção de um modelo de direito societário e sua mudança depende de inúmeros fatores, bem como que, ao contrário do que possa parecer, o sistema de capital disperso não é o mais utilizado no mundo, não obstante a existência de outras variações dos modelos de capital concentrado e disperso, verificaremos a seguir a realidade brasileira em termos de propriedade acionária, que historicamente tem sido marcada pela concentração, bem como o recente movimento autorregulatório tendente à dispersão acionária a partir da criação dois níveis de governança corporativa pela Bovespa. 


\section{REALIDADE BRASILEIRA: SISTEMA DE CAPITAL CONCENTRADO E DISPERSÃO ACIONÁRIA}

Feita uma verificação acerca dos principais fatores que influenciam a forma e extensão do mercado de capitais, bem como os principais fatores de resistência que impedem a mudança de um sistema de capital concentrado para um sistema de capital disperso e vice-versa, cumpre agora analisar os aspectos principais do mercado de capitais no Brasil, sobretudo em relação à concentração acionária e o movimento tendentel à dispersão acionária após a criação dos níveis de governança corporativa pela Bovespa. Antes, é preciso fazer uma breve retrospectiva histórica do mercado de capitais brasileiro para, então, chegarmos à sua situação atual.

Segundo o relato de Otavio Yazbek ${ }^{361}$, a reforma ocorrida em 1964 teve o condão de romper as origens do mercado financeiro como um todo, sem, contudo e obviamente, largar o legado e as instituições deixados até então pela legislação que vigorava.

Desde o descobrimento do Brasil em 1500, a economia colonial foi marcada pela escassez monetária, motivo pelo qual havia o prevalecimento do escambo. Além do escambo, também a economia colonial era marcada pelos monopólios outorgados pela Coroa Portuguesa aos comerciantes lisboetas. Tais monopólios existiam inclusive na atividade de arrecadação de tributos, cujas respectivas concessões eram outorgadas em favor das casas comerciais mais poderesas, que, segundo Ney Carvalho, viriam a ser " $a$ matriz na colônia do mercado de capitais que surgiria no século 19."362

$\mathrm{Na}$ época colonial, a instituição que mais se aproximou do que conhecemos por instituição financeira, pois não havia instituição que guardasse a poupança pública e a disponibilizasse para fins de financiamento, foram as ordens religiosas, especialmente os Jesuítas, que permitiam aos habitantes que depositassem suas economias em seus cofres, as

361 YAZBEK, Otavio. Regulação do Mercado Financeiro e de Capitais. 2. edição. Rio de Janeiro: Elsevier, 2009, p. 261 - 286.

${ }^{362}$ CARVALHO, Ney. A Saga do Mercado de Capitais no Brasil. São Paulo: Saint Paul, 2014, p. 9. 
quais eram utilizadas pela própria ordem religiosa para ostentar o luxo nas igrejas, todavia, as ordens religiosas não possuíam fins econômicos.

Além da escassez monetária, na época colonial, não havia instrumento de crédito que permitisse a sua circulação, mas, sim, havia apenas a instituição da conta corrente e do "fiado", cujos recebíveis não podiam ser transferidos a terceiros. Apenas os comerciantes atacadistas, importadores e exportadores concediam crédito aos compradores para pagamento em mercadoria ou em moeda, sendo que aqueles comerciantes, que eram conhecidos por comerciantes de grosso trato, foram o embrião do mercado financeiro e do mercado de capitais, especialmente no Rio de Janeiro que, no final do século XVIII e início do Século XIX, desenvolveu uma comunidade de negócios que emprestava dinheiro à Coroa Portuguesa para o custeio da agricultura nas Capitanias.

Com a vinda da Família Real para o Brasil Colônia em 22.01.1808, há um movimento inicial de criação e de desenvolvimento das estruturas financeiras locais, o que coincidiu com a conhecida abertura dos portos às nações amigas da Corte Portuguesa e, portanto, o início de uma intensificação comercial, bem como com a elevação do Brasil Colônia ao status de Reino Unido em 1815. Não obstante, a economia não tinha apresentado mudanças, pois ainda havia escassez de meio circulante, as riquezas produzidas não circulavam e não havia instituições fornecedoras de crédito, sendo que o ouro em pó servia de moeda.

Assim, em 24.02.1808, é criada a primeira sociedade seguradora a operar no Brasil Colônia, a Companhia de Seguros Boa-Fé, bem como em 08.10.1808 foi criado o Banco do Brasil, ao qual foram atribuídas funções de banco central e de banco comercial, especialmente para a emissão de moeda e para a captação de recursos para financiar o sustento da Família Real. Em 1808, pode-se afirmar que, no Brasil Colonial, houve a primeira operação de mercado de capitais, que consistiu no lançamento de ações do Banco do Brasil para a subscrição pública.

Segundo os relatos de Ney Carvalho ${ }^{363}$, a primeira menção a uma organização relativa ao mercado de capitais ocorreu em 15.07.1809, quando o príncipe regente assinou um alvará que criou tributo sobre o comércio, com diversas finalidades,

${ }^{363}$ CARVAlHO, Ney. A Saga do Mercado de Capitais no Brasil. São Paulo: Saint Paul, 2014, p. 19. 
dentre as quais a de financiar a construção de uma praça de comércio, que, segundo o art. 97 do Código Comercial Português de $1833^{364}$, era sinônimo de bolsa, denominação esta que também foi utilizada no Código Comercial Brasileiro de 1850, em seu art. $32^{365}$, que basicamente repete o teor do art. 97 do Código Comercial Português de 1833.

Em 1817, foi inaugurada a primeira bolsa de valores no Brasil, era a Praça do Comércio de Salvador, sendo que a Praça do Comércio do Rio da Janeiro foi inaugurada em 1820, mas somente entrou em operação alguns anos depois e foi abandonada em 1821, após a invasão de tropa militar na bolsa, quando ocorria uma reunião preparatória de eleitores para a escolha dos representantes às Cortes de Lisboa ${ }^{366}$. Já em 15.12.1827, foi criada a Caixa de Amortização, que exercia as funções de emissão, transferência, troca e controle dos papéis públicos em circulação, sendo que em 17.03.1828, foi publicado edital no Jornal do Commercio dando publicidade à primeira emissão de apólices da dívida pública. Em 1834, o mercado começou a tomar as iniciativas e providências necessárias para a implantação da segunda bolsa do Rio de Janeiro.

Em 01.05.1837, foi divulgada a primeira cotação de ações da Companhia Brasileira de Paquetes a Vapor e da Companhia de Navegação de Nictheroy, seguindo-se um período de diversos fatos relevantes para a história do mercado de capitais brasileiro, especialmente o lançamento de diversos empreendimentos com ofertas públicas de ações para subscrição, destacando-se que, em 24.04.1838, houve o lançamento de ações para subscrição pelo público para a constituição de um banco comercial, que recebeu e denominação de Banco Comercial, após o qual surgiram outras casas bancárias.

Assim, a partir de 1837 e 1838, ocorreram diversos eventos que forma de extrema relevância para o desenvolvimento do mercado financeiro e do mercado de capitais brasileiros, sendo que, durante o $2^{\circ}$ Reinado, que se iniciou em 23.07.1840 e

\footnotetext{
364 “97. Praça do commercio ou bolça é não só o local, mas também a reunião dos commerciantes, capitaens e mestres de navios, corretores e mais pessoas empregadas no commercio. Este local e reunião é sujeito á polícia e a autoridade designada na lei." (In: CARVALHO, Ney. A Saga do Mercado de Capitais no Brasil. São Paulo: Saint Paul, 2014, p. 19)

365 “Art. 32 - Praça do comércio é não só o local, mas também a reunião dos comerciantes, capitães e mestres de navios, corretores e mais pessoas empregadas no comércio.

Este local e reunião estão sujeitos à polícia e inspeção das autoridades competentes." (BRASIL. Lei n. ${ }^{\circ}$ 556, de 25 de junho de 1850. Código Comercial. Disponível em <http://www.planalto.gov.br/ccivil_03/leis/105561850.htm>. Acesso em 02.11.2014.)

${ }^{366}$ Vide relato percuciente de Ney Carvalho in: A Saga do Mercado de Capitais no Brasil. São Paulo: Saint Paul, 2014, p. $22-25$.
} 
estendeu-se até a proclamação da República do Brasil em 15.11.1889, constata-se uma prosperidade e um desenvolvimento maior da estrutura legal relativa às atividades bancárias. Com efeito, em junho de 1845, foi criado o primeiro regulamento da profissão de corretor por meio do Decreto n. ${ }^{\circ} 417$, que limitou o seu exercício, deixando de ser livre, além de atribuir caráter cartorário e corporativo à profissão, de modo que os mesmos limitavam-se a registrar a mudança da titularidade dos títulos em circulação, não tendo, o referido decreto, tratado os corretores "como agentes de negócios, ou captadores de poupança, capazes de imprimir agilidade e eficiência às transações com papéis, ampliando o mercado e capitalizando as empresas. ${ }^{, 367}$

Ademais, o Decreto n. ${ }^{\circ} 417 / 1845$ proibia os corretores de, direta ou indiretamente, realizar operações por conta própria, ficando limitados à intermediação de operações, o que, de acordo com Ney Carvalho, impediu o surgimento, no decorrer do tempo, de "uma indústria estruturada de investment banking no Brasil."368 Todavia, o referido Decreto, apesar apresentar normas retrógradas sobre a profissão de corretor, o mesmo não criava uma reserva de mercado, de modo que permitia a outras pessoas, ainda que não fossem corretoras, a realização de suas operações na Praça de Comércio.

Em 10.11.1849, foi editado o Decreto n. ${ }^{\circ}$ 648, que atribuía ao cargo de corretor um caráter de vitaliciedade e de hereditariedade, impedindo a existência de concorrência, levando, portanto, à ineficiência e à coibição do desenvolvimento do mercado de capitais, além de reforçar o caráter burocrático e notarial da função. Além das normas acima indicadas e que eram específicas da corretagem, tivemos também a promulgação do Código Comercial Brasileiro, Lei n. ${ }^{\circ}$ 556, de 25.06,1850, que trata diretamente da atividade bancária apenas nos arts. 119 e $120^{369}$, artigos estes pertencentes ao Título IV - Dos Banqueiros, da Primeira Parte - Do Comércio em Geral, bem como de maneira mais superficial no art. $285^{370}$ do Título XIV - Do Depósito Mercantil, da

\footnotetext{
${ }^{367}$ CARVALHO, Ney. A Saga do Mercado de Capitais no Brasil. São Paulo: Saint Paul, 2014, p. 52.

368 Idem, ibidem, p. 52.

369 “Art. 119 - São considerados banqueiros os comerciantes que têm por profissão habitual do seu comércio as operações chamadas de Banco.

Art. 120 - As operações de Banco serão decididas e julgadas pelas regras gerais dos contratos estabelecidos neste Código, que forem aplicáveis segundo a natureza de cada uma das transações que se operarem." (BRASIL. Lei n. ${ }^{\circ} 556$, de 25 de junho de 1850. Código Comercial. Disponível em <http://www.planalto.gov.br/ccivil_03/leis/10556-1850.htm>. Acesso em 02.11.2014.)

370 "Art. 285 - Os depósitos feitos em bancos ou estações públicas ficam sujeitos às disposições das leis, estatutos ou regulamentos da sua instituição." (Idem, ibidem)
} 
Primeira Parte - Do Comércio em Geral e, ainda, nos arts. 836 e $866^{371}$ do Título I - Da Natureza e Declaração das Quebras e seus Efeitos, da Terceira Parte - Das Quebras.

Desde a promulgação do Código Comercial, o mercado de capitais passou a assumir um papel de crescente relevância na economia imperial, época em que Irineu Evangelista de Souza, mais conhecido por Barão e Visconde de Mauá, atuou ativamente neste aquecimento da economia e do mercado de capitais ${ }^{372}$, com o lançamento de diversos empreendimentos, os quais, invariavelmente, recorriam ao mercado de capitais para subscrição pública de ações.

Em meio à crescente importância do mercado de capitais na vida econômica imperial, em consequência da bolha especulativa concretizada no decorrer dos anos $1850 \mathrm{e}$, ainda, retratando o pensamento da época contrário à concorrência de bancos, que, causaria uma queda nos juros para favorecer a captação de clientela e, consequentemente, estimularia a formação de empresas aleatórias em detrimento dos capitais reais disponíveis, inicia-se uma fase legislativa de restrições, tal como o Decreto . $^{\circ} 2.457$, de setembro de 1859, que exigia dos bancos e das sociedades por ações o envio ao Tesouro de balanços semanais compilando todas as operações ocorridas.

Ainda, em 1860, foi promulgada a Lei n. ${ }^{\circ} 1.083$, de 22.08.1860, que ficou conhecida como a Lei dos Entraves (ou para os políticos da época, ficou conhecida por Lei de Prudência), visto que impôs inúmeras limitações à emissão de títulos, restringindo, portanto, esta prática, de modo que fulminava a liberdade de empreendimento, criava

371 “Art. 836 - As somas provenientes de venda de efeitos ou cobranças, abatidas as despesas e custas, serão lançadas em caixa de duas chaves, das quais terá o Curador fiscal uma e o depositário outra; salvo se os credores acordarem em que sejam recolhidas a algum Banco comercial ou depósito público."

"Art. 866 - Todas as quantias recebidas serão arrecadadas em caixa de duas chaves, uma das quais se conservará sempre no poder do Juiz comissário e outra na mão de um dos administradores; salvo o caso em que os credores se acordarem em serem depositadas em algum Banco comercial ou depósito público." (BRASIL. Lei n. ${ }^{\circ} 556$, de 25 de junho de 1850. Código Comercial. Disponível em <http://www.planalto.gov.br/ccivil_03/leis/10556-1850.htm>. Acesso em 02.11.2014.)

372 “Apenas oito meses após ter abdicado de influir nos destinos do Banco do Brasil, em 31 de julho de 1854, Mauá reuniu 182 investidores para formar uma nova casa bancária: a Mauá, MacGregor \& Cia., de acordo com suas ideias e objetivos econômicos (...) O nascimento da empresa obedeceu a uma arquitetura jurídica e comercial que visava contornar as restrições impostas, então, à criação de sociedades anônimas. Essas deveriam se submeter à aprovação dos estatutos e demais controles exigidos pelo Governo Imperial, o que tornava previsível sua obstrução pelos conservadores, que já haviam forçado a fusão dos bancos em 1853. A solução encontrada, usando brechas legais, foi, mutatis mutandis, digna dos mais criativos bancos de investimentos e escritórios de advocacia da atualidade. Tratava-se do uso de uma sociedade em comandita, mas na qual os sócios comanditários receberiam ações. Essa era a grande inovação." (CARVALHO, Ney. A Saga do Mercado de Capitais no Brasil. São Paulo: Saint Paul, 2014, p. 63) 
diversos empecilhos ao desenvolvimento do mercado de capitais ${ }^{373}$, causando, ainda, uma escassez de liquidez, dando origem, segundo Otavio Yazbek, à primeira crise bancária, que culminaria com a Falência da Casa Bancária Antônio José Alves Souto \& Cia. em 1864, falência esta que foi seguida pela inadimplência de outras casas bancárias e pela falência de inúmeras empresas, sem se considerar o movimento de "corrida bancária" que durou algumas semanas após a quebra da Casa Bancária Antônio José Alves Souto \& Cia..

Ainda sob a vigência da Lei dos Entraves, São Paulo iniciou um movimento crescente de criação de empresas e do próprio mercado de capitais, de maneira espontânea, sem a intervenção do Estado e, ainda, de criação de uma rede de intermediários informais, surgindo um verdadeiro mercado de balcão que visava ao financiamento dos empreendimentos locais. Apesar da estagnação causada pela Lei dos Entraves, a partir de 1871, há uma revitalização do mercado de capitais constatada com o aumento considerável da cotação das ações dos bancos cotados, bem como das ações de empresas cotadas, o que fez surgir oportunidade para novos empreendimentos que foram estimulados mais ainda a partir de 04.11.1882, quando foi promulgada a Lei n. $^{\circ} 3.150$ que revogou as restrições à criação das sociedades por ações contidas na Lei n. ${ }^{\circ}$ 1.083/1860.

Em 1890, após a abolição da escravatura em 13.05.1888 e a proclamação da República em 15.11.1889, as operações da bolsa também foram atingidas pelo otimismo, o que fez aumentar ainda mais os lançamentos de novos empreendimentos. Em 17.01.1890, o governo republicano promulgou novas leis sobre bancos e sociedades anônimas, causando ainda mais lançamentos de novos empreendimentos.

Somente em 1890 é criada uma Bolsa para operar valores financeiros, o que ocorreu em São Paulo por iniciativa de Emílio Rangel Pestana, mas que culminou com seu fechamento diante da Crise do Encilhamento em 1891, causada pela emissão desenfreada e especulativa de títulos diante da "política financeira de estímulo à indústria criada pelo Ministro Ruy Barbosa, baseada no aumento do meio circulante com a criação de bancos emissores, trocando o lastro-ouro por títulos da dívida pública, que resultou em espiral

373 "Ficavam proibidos a organização ou funcionamento de sociedades anônimas ou companhias, de qualquer ramo de atividade, sem autorização prévia do governo por meio de lei ou decreto do Poder Executivo (...) Era ainda vedada a emissão de qualquer documento que representasse ações antes do governo declarar constituída uma sociedade anônima. E mesmo depois disto, as ações só poderiam ser negociadas quando integralizados $25 \%$ de seu valor." (CARVALHO, Ney. A Saga do Mercado de Capitais no Brasil. São Paulo: Saint Paul, 2014, p. 89) 
inflacionária e grande número de falências." ${ }^{374}$ Apenas em 1895 foi criada a Bolsa de Títulos de São Paulo, que, em 1934, tornou-se a bolsa oficial de valores de São Paulo, a qual, em 1967, passou a chamar-se Bolsa de Valores de São Paulo - BOVESPA e, em 2008, passou a ser chamada BM\&FBovespa em razão da integração das bolsas.

A euforia causada pelos novos empreendimentos sentiu drasticamente os efeitos do Decreto n. ${ }^{\circ}$ 850, de 13.10.1890, que tinha por fim imediato diminuir a criação de novas sociedades por ações, de modo que, para tanto, passou a exigir a subscrição de $30 \%$ (trinta por cento) da parcela inicial de cada subscrição de ações, a integralização de $20 \%$ (vinte por cento) do valor subscrito para que fosse possível a negociação das ações e, ainda, "proibia-se o uso de procurações em causa própria, prática que facilitava a circulação dos títulos como se fossem ao portador, antes mesmo de integralizado o mínimo exigido por lei." 375

Não obstante, o mercado de capitais retomou o ritmo de negócios até que, em 14.02.1891, o então Ministro da Fazenda, Tristão de Alencar Araripe, editou o Decreto n..$^{\circ} 1.362$, por meio do qual criou um imposto de $3 \%$ (três por cento) sobre as operações futuras, que constituíam, naquela época, a fonte de financiamento primordial das posições em ações, o que levou a uma queda vertiginosa dos preços das ações cotadas em bolsa e causou uma imediata estagnação do mercado de capitais, que foi acompanhada pela falência de inúmeras empresas que, mesmo fazendo chamadas a seus acionistas para a integralização de suas participações, não obtinham êxito em virtude da desvalorização grande ocorrida em suas posições de ações, o que levou as empresas à inadimplência de inúmeros compromissos assumidos, culminando com a respectiva falência. Estava, assim, deflagrada a Crise do Encilhamento.

Segundo Otavio Yazbek, a Crise de Encilhamento causou grave desconfiança na emissão de títulos financeiros, o que levou o governo a reagir à situação especulativa, in verbis:

374 COMISSÂO DE VALORES MOBILIÁRIOS. O Mercado de Valores Mobiliários Brasileiro. 2. ${ }^{\text {a }}$ edição. Rio de Janeiro: Comissão de Valores Mobiliários, 2013, nota de rodapé n. ${ }^{\circ}$ 1, p. 222. Disponível em 〈http://www.cvm.gov.br/port/public/Livro-TOP-2ed.pdf>. Acesso em 30.10.2013.

${ }^{375}$ CARVALHO, Ney. A Saga do Mercado de Capitais no Brasil. São Paulo: Saint Paul, 2014, p. 119. 
"O governo respondeu àquela situação, em um primeiro momento, acabando com a faculdade de emissão dos bancos e recolhendo moeda em circulação. Muitos autores identificam, aí, os primeiros sintomas da generalizada desconfiança em relação à emissão de títulos financeiros $e$ a movimentos especulativos, uma constante na história brasileira." ${ }^{376}$

A reação governamental à Crise do Encilhamento acabou dificultando as operações financeiras com títulos e valores mobiliários, o que é confirmado por Marcílio Marques Moreira:

"Se lançarmos vista para um momento mais longínquo de nosso passado econômico, é, em contraste, necessário constatar que as operações com valores mobiliários no país foram engessadas pela legislação editada em 1895 como reação radical ao Encilhamento, o estouro da Bolsa em 1891-92, e só foram capazes de voltar a respirar com mais liberdade de ação 70 anos depois". ${ }^{377}$

Com a crise sofrida em 1891, foi produzida uma nova leva de atos legislativos com a finalidade de evitar a repetição do episódio ocorrido. Foi, justamente, neste ambiente, que os corretores do Rio de Janeiro exitosamente recuperaram os privilégios que possuíam na época da vigência da Lei dos Entraves, o que foi possível por meio do Decreto n. ${ }^{\circ} 1.359$, de 20.04.1893, que veiculou o novo regulamento da atividade de corretor. Aliado àquele decreto foi editado também o Decreto n. ${ }^{\circ}$ 2.475, de 13.03.1897, que veiculou uma porção de medidas restritivas e de caráter retrógrado, que implicou em verdadeiro retrocesso do mercado de capitais.

Diante desta situação de crise, o Século XX foi iniciado sob uma grande austeridade monetária, sendo que o sistema financeiro vivia uma grave falta de liquidez. $\mathrm{O}$ Banco do Brasil, por sua vez, após inúmeros auxílios do governo, chegou a suspender os pagamentos, culminando com a intervenção do governo por meio de nomeação de dois

${ }^{376}$ YAZBEK, Otavio. Regulação do Mercado Financeiro e de Capitais. 2. ${ }^{\text {a }}$ edição. Rio de Janeiro: Elsevier, 2009, p. 265.

${ }^{377}$ Prefácio à $2^{\mathbf{a}}$ Edição (2010) - Um Livro Revisitado: O Mercado de Capitais Brasileiro, Avanços Relevantes e Desafios à Frente. In: TRUBEK, David M.; VIEIRA, Jorge Hilário Gouvêa; SÁ, Paulo Fernandes de. Direito, Planejamento e Desenvolvimento do Mercado de Capitais Brasileiro 1965-1970. 2. ${ }^{a}$ edição. São Paulo: Saraiva, 2011, p. 10. 
diretores dirigentes e, posteriormente, com a assunção do controle do banco pelo governo em 1906.

Superada a fase de turbulência causada pela Crise do Encilhamento, atingida a estabilidade da moeda e adotado o padrão ouro, iniciou-se uma nova fase de crescimento do mercado de capitais, especialmente em relação às operações de debêntures, bem como à negociação relativa a empréstimos públicos feitos pelos Municípios, sobretudo Municípios do Estado de São Paulo. Há que se ressaltar, também, que nesta fase de crescimento do mercado de capitais brasileiro, houve uma intensa participação do capital estrangeiro.

Antes mesmo da segunda metade do Século XIX, em razão do caráter essencialmente agrário do país, os comerciantes dos produtos agrícolas já conheciam e praticavam operações para liquidação futura, com o objetivo principal de proteger o agricultor e o próprio comerciante da oscilação dos preços. Nas praças de comércio, era comum a negociação de produtos agrícolas a termo ou para entrega à vista. Mas, somente em 1910 foi criada a Bolsa de Mercadorias do Distrito Federal, que teve uma rápida duração. Já em 1914 é crida a Bolsa Oficial do Café de Santos, tendo sido inaugurada apenas em 1917, ano em que foi criada a Bolsa de Mercadorias de São Paulo, esta considerada um verdadeiro marco relevante do mercado de commodities no Brasil, que foi constituída sob as mesmas bases da Bolsa Livre de São Paulo, tornando-se um grande centro de negociações de mercadorias, especialmente de algodão.

A partir do governo Vargas, em 1930, assistiu-se a um período ditatorial de extrema intervenção no âmbito econômico, com a adoção de diversas medidas totalmente contrárias aos negócios e ao mercado, tanto que o mercado de debêntures, que tinha apresentado uma grande evolução, simplesmente foi extinto nos anos do governo Vargas, tendo havido um verdadeiro estrangulamento do mercado de capitais, como bem relatou Ney Carvalho:

"Durante os anos Vargas, não foi dada ao mercado de capitais a oportunidade histórica de institucionalizar um mecanismo de financiamento à industrialização no Brasil. Na década de 1930 surgiram os maiores investidores institucionais em potencial do país, repositórios 
da poupança nacional, sem que o mercado fosse levado em consideração como gestor ou destinatário até mesmo eventual de tais recursos. "378

Em 1938, o Decreto-lei n. ${ }^{\circ}$ 967, de 21.12.1938, proibiu expressamente a emissão de títulos da dívida pública pelos Estados e Municípios, sem que houvesse a prévia autorização do governo federal, o que constituiu um verdadeiro ato contrário ao livre funcionamento do mercado de capitais e à liberdade negocial, sem prejuízo da manutenção do caráter cartorário e corporativo das estruturas básicas do mercado de capitais por meio do Decreto-lei n. ${ }^{\circ}$ 1.344, de 13.06.1939 e, ainda, da criação de obrigações de guerra destinadas ao custeio das despesas com a segurança nacional, cuja subscrição obrigatória ocorria com a cobrança de uma alíquota maior dos contribuintes de imposto sobre a renda, bem como dos assalariados e funcionários públicos, sendo que sua devolução ocorria por meio das obrigações de guerra.

Com o fim da $2^{\mathrm{a}}$ Guerra Mundial, constata-se a criação, pelo governo brasileiro, de instituições que serviram de base para que, a partir de 1964, houvesse uma reestruturação do sistema financeiro nacional. Assim, foram criados, por exemplo, o Banco Nacional de Desenvolvimento Econômico, o Banco do Nordeste do Brasil, o Banco da Amazônia, a Superintendência da Moeda e do Crédito.

Segundo Benedicto Ferri de Barros, a partir de 1950 constata-se uma popularização dos investimentos e das práticas financeiras, com uma mudança de mentalidade no mercado, visto que até então prevalecia uma mentalidade, que é bem resumida por Benedicto Ferri de Barros: "Costuma-se dizer que o brasileiro é imobiliário por excelência. ${ }^{379}$ Neste década de 50, houve uma intensificação do crédito destinado ao mercado consumidor, com o desenvolvimento de sociedades de crédito, de financiamento e de investimento que visaram ao fornecimento de crédito aos consumidores considerados individualmente.

Justamente neste período de transformação da mentalidade dos empresários brasileiros, houve o surgimento diversas instituições que, como já dito, formam a base

\footnotetext{
${ }^{378}$ CARVAlHO, Ney. A Saga do Mercado de Capitais no Brasil. São Paulo: Saint Paul, 2014, p. 162.

379 BARROS, Benedicto Ferri. Mercado de Capitais e ABC de Investimentos. São Paulo: Atlas, 1967, p. 59.
} 
estrutural que servirá para a reforma realizada a partir de 1964. Assim, há (i)o surgimento de organizações especializadas na captação de recursos para o financiamento empresarial, bem como (ii) de organizações distribuidoras de valores, (iii) ocorre a abertura e a ampliação do mercado mobiliário, (iv) surgem os fundos de investimentos que, inicialmente, assumiram a forma de sociedades em conta de participação, (v) há a criação de companhias de crédito e financiamento que suprem uma lacuna existente no crédito de médio prazo, o que é feito com a ampliação do mercado de valores mobiliários por meio do uso de letras de câmbio para o financiamento das vendas de bens duráveis, bem como do uso de debêntures de médio prazo.

Aliado ao surgimento das instituições acima mencionadas, houve ainda um notável desenvolvimento das atividades complementares às atividades de emissão e distribuição de títulos no mercado de capitais, como bem indicou Benedicto Ferri de Barros:

"Paralelamente ao desenvolvimento das atividades de lançamento $e$ distribuição de títulos, à organização das Companhias e Fundos de Investimentos, à atividade das Companhias de Crédito e Financiamento, foram se desenvolvendo no Brasil as organizações e serviços complementares (...) Criaram-se, assim, algumas organizações de comerciantes de títulos, que ensaiam, modestamente, atividades análogas à dos dealers americanos, distribuindo papéis e comprando e vendendo títulos. Criaram-se, igualmente, boletins especializados em investimentos, destacando-se o da Organização Nacional de Investimentos em moldes semelhantes aos statistical services americanos. Organizaram-se, entre outras, no Rio e em São Paulo, a ADECIF e a ACREFI, Associações das Companhias de Crédito, Financiamento e Investimentos, e a ADEVAL - Associação dos Distribuidores de Valores com funções semelhantes às de suas congêneres americanas. É patente o aumento e aprimoramento da publicidade financeira., ${ }^{, 380}$

${ }^{380}$ BARROS, Benedicto Ferri. Mercado de Capitais e ABC de Investimentos. São Paulo: Atlas, 1967, p. 61 a p. 62. 
Criadas instituições públicas no âmbito financeiro de forma crescente desde 1920, em 1962 o Brasil apresentou um aumento das transações ocorridas no mercado de capitais, mas que foi seguida por uma queda que se agravou com as crises econômica e política a partir de 1963, que culminaram com o golpe militar em 1964.

O governo militar adotou um novo modelo com ampla reforma das estruturas financeiras do Brasil, visando ao aprofundamento do sistema financeiro, ampliando-o de maneira a aumentar as atividades financeiras proporcionalmente ao aumento das atividades econômicas, isto é, visando à formação de uma poupança destinada a servir ao investimento na própria produção industrial, oferecendo, para tanto, instrumentos diversos.

Somente com a promulgação da Lei $n .^{\circ} 4.595$, de 31.12 .1964 , foi criado o Banco Central do Brasil, cuja origem encontra-se na Superintendência da Moeda e do Crédito, a qual, pelo art. $8 .^{{ }^{381}}$ da retro referida lei, foi transformada em autarquia federal. Além disso, a Lei n. ${ }^{\circ}$ 4.595/64 estabeleceu a estrutura fundamental do Sistema Financeiro Nacional.

Desde então, constatou-se a crescente edição de normas destinadas ao desenvolvimento do mercado de capitais $^{382}$, culminando com a promulgação da Lei n. $^{\circ}$ 4.728, de 14.07.1965, que disciplinou o mercado de capitais, objetivando seu desenvolvimento por meio da: (i) facilitação do acesso, pelo público, às informações sobre os títulos e valores mobiliários e as sociedades emissoras dos mesmos; (ii) proteção dos investidores contra práticas ilícitas; (iii) da coibição de fraude e de manipulação das condições de mercado; (iv) observância de práticas comerciais equitativas entre os

\footnotetext{
381 "Art. $8^{\circ} \mathrm{A}$ atual Superintendência da Moeda e do Crédito é transformada em autarquia federal, tendo sede e foro na Capital da República, sob a denominação de Banco Central da República do Brasil, com personalidade jurídica e patrimônio próprios este constituído dos bens, direitos e valores que the são transferidos na forma desta Lei e ainda da apropriação dos juros e rendas resultantes, na data da vigência desta lei, do disposto no art. $9^{o}$ do Decreto-Lei número 8.495, de 28/12/1945, dispositivo que ora é expressamente revogado." (BRASIL. Lei n. ${ }^{\circ} 4.595$, de 31 de dezembro de 1964. Dispõe sobre a política e as instituições monetárias, bancárias e creditícias, cria o Conselho Monetário Nacional e dá outras providências. Disponível em <http://www.planalto.gov.br/ccivil_03/leis/14595.htm>. Acesso em 02.11.2014)

382 "Os meses e anos seguintes testemunharam a edição dos atos legislativos que lançaram a base de uma nova era para o mercado de capitais. Este tem, desde então, percorrido linha ascendente quantitativa e qualitativamente. Mas como sói ser da natureza dos mercados, a trajetória nunca é linear." (MOREIRA, Marcílio Marques. Prefácio à $2^{\mathbf{a}}$ Edição (2010) - Um Livro Revisitado: O Mercado de Capitais Brasileiro, Avanços Relevantes e Desafios à Frente. In: TRUBEK, David M.; VIEIRA, Jorge Hilário Gouvêa \& SÁ, Paulo Fernandes de. Direito, Planejamento e Desenvolvimento do Mercado de Capitais Brasileiro 1965-1970. 2. edição. São Paulo: Saraiva, 2011, p. 11)
} 
profissionais de intermediação e negociação de títulos e valores mobiliários; (v) disciplina da utilização do crédito no mercado de capitais; e (vi) regulação da atividade corretora de títulos mobiliários e de câmbio ${ }^{383}$.

Os mecanismos utilizados pelo governo incentivavam o investimento a longo prazo via mercado de capitais, adotando um modelo centrado mais nos interesses do mercado que nos interesses dos bancos, de modo que promulgou um conjunto de normas instituidoras das bases para as atividades de intermediação de títulos e valores mobiliários, bem como para a regulação do mercado de capitais, o que foi complementado com a criação de incentivos fiscais indutores da abertura de capital das companhias e da compra de ações por meio da promulgação, por exemplo, do Decreto-lei n. ${ }^{\circ}$ 157, de 10.02.1967.

Desse modo, percebe-se que desde a década de 60 o mercado de capitais e o mercado financeiro passaram a ser estruturados institucionalmente de uma maneira mais intensa, tendo como prioridade o desenvolvimento de instrumentos que levassem a um crescimento do financiamento da atividade produtiva via mercado de valores mobiliários, sem o recurso ao crédito governamental, como bem ressaltou Eduardo Secchi Munhoz:

“O mercado financeiro e o mercado de capitais somente foi estruturado (sic) de forma institucional com as reformas da década de 1960 (Lei $n .^{o}$ 4.595/1965 - sistema financeiro; Lei n. ${ }^{o} 4.728 / 1965$ - mercado de capitais). $O$ objetivo de desenvolver-se um mercado privado de

\footnotetext{
${ }^{383}$ Lei n. $^{\circ}$ 4.728/65: "Art. $2^{\circ}$ O Conselho Monetário Nacional e o Banco Central exercerão as suas atribuições legais relativas aos mercados financeiro e de capitais com a finalidade de:

I - facilitar o acesso do público a informações sobre os títulos ou valores mobiliários distribuídos no mercado e sobre as sociedade que os emitirem;

II - proteger os investidores contra emissóes ilegais ou fraudulentas de títulos ou valores mobiliários;

III - evitar modalidades de fraude e manipulação destinadas a criar condições artificiais da demanda, oferta ou preço de títulos ou valores mobiliários distribuídos no mercado;

IV - assegurar a observância de práticas comerciais equitativas por todos aqueles que exerçam, profissionalmente, funções de intermediação na distribuição ou negociação de títulos ou valores mobiliários;

$V$ - disciplinar a utilização do crédito no mercado de títulos ou valores mobiliários;

VI - regular o exercício da atividade corretora de títulos mobiliários e de câmbio." (BRASIL. Lei n. ${ }^{\circ}$ 4.728, de 14 de julho de 1965. Disciplina o mercado de capitais e estabelece medidas para o seu desenvolvimento. Disponível em < http://www.planalto.gov.br/ccivil_03/leis/14728.htm>. Acesso em 02.11.2014)
} 
financiamento de longo prazo às empresas tornou-se prioritário apenas a partir dos anos 1970.,384

Não obstante a supra mencionada estruturação institucional do sistema financeiro como um todo, bem como as constantes adoções de instrumentos incentivadores do desenvolvimento do mercado de capitais pelo governo, o que acabou aumentando o volume de recursos destinados ao mercado de capitais em razão dos incentivos fiscais dados pelo governo, no final de 1970 há uma crescente demanda pela compra de ações, embora não houvesse o respectivo aumento da oferta com novas emissões, culminando com uma nova crise em julho de 1971, que ficou conhecida como "boom de 1971:

“Após alcançar o seu ponto máximo em julho de 1971, iniciou-se um processo de realização de lucros pelos investidores mais esclarecidos $e$ experientes que começaram a vender suas posições. $O$ quadro foi agravado progressivamente quando novas emissões começaram a chegar às bolsas, aumentando a oferta de ações, em um momento em que muitos investidores, assustados com a rapidez e a magnitude do movimento de baixa, procuravam vender seus títulos.

O movimento especulativo, conhecido como "boom de 1971", teve curta duração, mas suas consequências foram vários anos de mercado deprimido, pois algumas ofertas de ações de companhias extremamente frágeis e sem qualquer compromisso com seus acionistas, ocorridas no período, geraram grandes prejuízos e mancharam de forma surpreendentemente duradoura a reputação do mercado acionário. Apesar disso, notou-se uma recuperação das cotações, a partir de 1975, devido a novos aportes de recursos (as reservas técnicas das seguradoras, os recursos do Fundo PIS/ PASEP, adicionais do Fundo 157 e a criação das Sociedades de Investimento "Decreto- Lei $n^{\circ} 1401$ "

${ }^{384}$ MUNHOZ, Eduardo Secchi. Aquisição de Controle na Sociedade Anônima. São Paulo: Saraiva, 2013, p. 87. 
para captar recursos externos e aplicar no mercado de ações), além de maiores investimentos por parte dos Fundos de Pensão."385

Neste quadro de estagnação do mercado de capitais e de tentativas de retomar sua recuperação rumo ao crescimento como reação à crise de $1971^{386}$, foram promulgadas novas leis, quais sejam a lei que criava a Comissão de Valores Mobiliários (Lei n. ${ }^{\circ}$ 6.385, de 07.12.1976) justamente com a finalidade de criar um órgão regulador específico do mercado de valores mobiliários, bem como da nova lei que estabeleceu o regime jurídico da sociedade por ações (Lei n. ${ }^{\circ}$ 6.404, de 15.12.1976), as quais estavam voltadas ao ideal de um mercado de capitais propício ao desenvolvimento ${ }^{387}$ com a intensificação do uso do mercado de valores mobiliários para o financiamento da atividade econômica produtiva.

Contudo, apensar da estrutura legal ser favorável ao desenvolvimento das transações no mercado de capitais, o volume de negócios não teve crescimento relevante, mesmo com a promulgação do Decreto-lei n. ${ }^{\circ}$ 1.401, de 07.05.1975, que concedia isenção de imposto sobre a renda das sociedades de investimento, que apresentassem participação de pessoas físicas ou jurídicas, residentes no país ou no exterior, em seu capital social.

\footnotetext{
385 COMISSÃO DE VALORES MOBILIÁRIOS. O Mercado de Valores Mobiliários Brasileiro. 2. ${ }^{a}$ edição. Rio de Janeiro: Comissão de Valores Mobiliários, 2013, nota de rodapé n. ${ }^{\circ}$ 1, p. 40 - 41. Disponível em <http://www.cvm.gov.br/port/public/Livro-TOP-2ed.pdf>. Acesso em 30.10.2013.

386 "Mesmo as duas leis inicialmente promulgadas para regular o mercado acionário, disciplinando as companhias e dispondo sobre a regulação do mercado, surgiram, sobretudo, como uma mera reação aos problemas ocorridos no início da década. Da mesma forma, a Lei n. ${ }^{\circ}$ 6.024/1974 surge em decorrência das quebras de instituições financeiras fragilizadas ou de alguma maneira afetadas pelo processo inflacionário." (YAZBEK, Otavio. Regulação do Mercado Financeiro e de Capitais. 2. ${ }^{a}$ edição. Rio de Janeiro: Elsevier, 2009, p. 276)

387 "Nos anos seguintes, importantes avanços nos processos de reforma estrutural e construção institucional foram trilhados, cabendo ressaltar, por sua relevância, além do Decreto-Lei n. 157, de 1967, um dos focos deste estudo, a Lei n. 6.385, de 7 de dezembro de 1976, que criou a Comissão de Valores Mobiliários - CVM e, assim, institucionalizou a regulação e fiscalização do mercado de capitais. A Lei n. 6.404, das Sociedades Anônimas, promulgada apenas uma semana depois, em 15 de dezembro de 1976, veio fornecer, por sua vez, eficaz arcabouço legal para as empresas dispostas a se modernizar e marco regulatório indispensável para o desenvolvimento sadio do mercado de capitais." (MOREIRA, Marcílio Marques. Prefácio à $\mathbf{2}^{\mathbf{a}}$ Edição (2010) - Um Livro Revisitado: O Mercado de Capitais Brasileiro, Avanços Relevantes e Desafios à Frente. In: TRUBEK, David M.; VIEIRA, Jorge Hilário Gouvêa; SÁ, Paulo Fernandes de. Direito, Planejamento e Desenvolvimento do Mercado de Capitais Brasileiro 1965-1970. 2. a edição. São Paulo: Saraiva, 2011, p. 12)
} 
Segundo Marcílio Marques Moreira ${ }^{388}$, esta estagnação do mercado de capitais deve-se, sobretudo, ao contexto macroeconômico extremamente desfavorável, que gerava instabilidade, incerteza, volatilidade e imprevisibilidade, o que era incompatível com um ambiente necessário ao desenvolvimento do mercado de capitais e, ainda, era agravado com os constantes planos de estabilização econômica que afrontavam as regras básicas de mercado, motivo pelo qual a década de 1980 não apresentou uma evolução do mercado de capitais.

Somente no final da década de 80 , há uma abertura do mercado de capitais brasileiro, cujo objetivo era atrair capitais estrangeiros para o mercado brasileiro, o que foi objeto da Resolução CMN n. ${ }^{\text {o }} 1.289$, de $20.03 .1987^{389}$, que regulamentava a constituição, o funcionamento e a administração de sociedade de investimento que apresentasse a participação de pessoas físicas ou jurídicas, residentes, domiciliadas ou com sede no exterior. Simultaneamente à mencionada abertura, há a criação de novos mecanismos de proteção aos agentes atuantes no mercado de capitais, como, por exemplo, a criação da CETIP, enquanto sociedade por ações de capital aberto que oferece serviços de registro, negociação e liquidação de ativos e títulos, além de servir de central depositária, bem como a promulgação do Decreto-lei n. 2.286 , de 23.07.1986, que fornece as bases dos derivativos.

A tentativa de atrair o capital estrangeiro juntamente com a abertura econômica brasileira acabou causando um aumento do volume de capital estrangeiro

\footnotetext{
388 "Na década de 80, a trajetória ascendente do mercado foi prejudicada pelo contexto macroeconômico, fragilizado, volátil e imprevisível. Danosos surtos de inflação eram intercalados por planos de estabilização 'heterodoxos', que ao agredir tanto as regras básicas do Estado de Direito quanto as do mercado, acabaram produzindo efeitos tão danosos quanto os males que se propunham remediar. Geraram-se, assim, instabilidade conjuntural e incerteza jurisdicional que inviabilizaram a consolidação de ambiente atrativo de negócios. Felizmente, entretanto, não foram capazes de inibir o progresso institucional. Criou-se então o Tesouro Nacional e aboliu-se a 'conta de movimento', que até então prendia o Banco do Brasil umbilicalmente ao Banco Central (...) O clima macroeconômico tornou-se incompatível com a evolução sadia do mercado de capitais, que só pode voltar a leito mais promissor há 15 anos com a implementação exitosa do Plano Real, que devolveu ao Brasi a noção e a realidade de uma moeda nacional." (MOREIRA, Marcílio Marques. Prefácio à $2^{\mathbf{a}}$ Edição (2010) - Um Livro Revisitado: O Mercado de Capitais Brasileiro, Avanços Relevantes e Desafios à Frente. In: TRUBEK, David M.; VIEIRA, Jorge Hilário Gouvêa \& SÁ, Paulo Fernandes de. Direito, Planejamento e Desenvolvimento do Mercado de Capitais

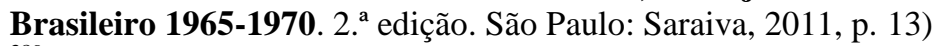

389 "Há que se apontar, porém, que, em fins da década de 1980 (mais exatamente em 1987), surgem normas cujo contexto e cujos efeitos merecem, aqui, destaque. Com elas, a regulamentação brasileira começava a reagir a algumas tendências internacionais, iniciando-se um movimento que, como se verá, vai desaguar no regime regulatório constituído em meados da década seguinte." (YAZBEK, Otavio. Regulação do Mercado

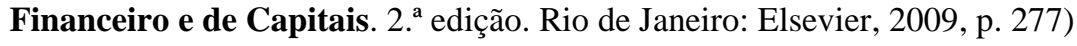


investido no mercado de capitais brasileiro, bem como incentivou algumas empresas a negociar suas ações no mercado de capitais estrangeiro, participando da listagem em bolsas de valores estrangeiras, o que as obrigou a adotar um padrão maior de transparência e divulgação de informações, além da adoção de padrão contábil internacional.

Contudo, a instabilidade da economia brasileira e a ausência de mecanismos eficazes de monitoramento das companhias impediam os investidores de mensurar os riscos e, por isso, o mercado de capitais brasileiro perdia espaço para outros mercados. Somente com o Plano Real, em 1994, o Brasil começou a apresentar aspectos macroeconômicos mais sólidos e, portanto, favoráveis ao desenvolvimento do mercado de capitais $^{390}$, fundados na estabilidade monetário-financeira, na austeridade fiscal, nas metas de inflação e na flutuação cambial, o que passou a possibilitar aos investidores maior previsibilidade e, desse modo, o país atraiu o fluxo de capitais destinados aos países emergentes, categoria esta atingida pelo Brasil.

Diante deste quadro macroeconômico favorável ao mercado de capitais, no âmbito da regulação e das estruturas financeiras, presencia-se uma verdadeira reformulação das práticas existentes, além da criação de novas medidas, especialmente no âmbito da regulação prudencial (como $(i)$ a incorporação de regras constantes do Acordo da Basiléia, (ii) criação de central de risco de crédito, (iii) obrigatoriedade de classificação do crédito assumido pelo mecanismo de rating etc.) e da regulação sistêmica (tal como (i) a criação do Fundo Garantidor de Crédito e a (ii) criação do novo Sistema de Pagamentos Brasileiro), sem prejuízo do desenvolvimento de programas de restruturação das instituições financeiras em dificuldades econômico-financeiras.

Justamente com a estabilização monetária proporcionada pelo Plano Real e com a inserção do mercado de capitais brasileiro no mercado mundial, constata-se a

\footnotetext{
390 “O movimento de transformação derivou, primeiro, da estabilidade macroeconômica. Segundo, da crescente demanda por capitais para financiar as inúmeras oportunidades para desenvolver empreendimentos econômicos rentáveis no Brasil. Terceiro, da disponibilidade de recursos para investimento, sobretudo, no mercado financeiro internacional. Quarto, da iniciativa da Bolsa de São Paulo de criar regras de listagem capazes de oferecer proteção adequada aos investidores

Em conclusão, a convergência de fatores econômicos favoráveis e a experiência de autorregulação levaram ao surto de desenvolvimento do mercado de capitais brasileiro no ano 2000, a despeito dos mecanismos de resistência do modelo anterior de capital concentrado, com elevada extração de benefícios privados pelo controlador." (MUNHOZ, Eduardo Secchi. Aquisição de Controle na Sociedade Anônima. São Paulo: Saraiva, 2013, p. 99)
} 
adoção de um modelo voltado ao mercado, dotado de coerência e técnica, que valoriza as estruturas reguladoras no âmbito do sistema financeiro nacional.

Diante deste novo panorama do mercado de capitais brasileiro, o Brasil apresentou uma atividade autorregulatória intensa de maior proteção aos investidores e aos acionistas, ou seja, a atividade autorregulatória voltou-se à produção de padrões de governança corporativa como, exemplificativamente, o Código de Melhores Práticas de Governança Corporativa lançado em 1999 pelo IBGC - Instituto Brasileiro de Governança Corporativa e os níveis diferenciados de governança corporativa lançados no ano de 2000 pela então Bovespa - Bolsa de Valores de São Paulo, o que foi timidamente seguido, posteriormente, por reformas da legislação, como, por exemplo, a reforma efetivada por meio da Lei n. ${ }^{\circ} 10.303 / 2001$.

A iniciativa autorregulatória acabou introduzindo nesta seara do direito societário, a competição entre os sistemas de normas autorregulatórias e de normas regulatórias de origem estatal, permitindo a coexistência de ambos os regimes jurídicos, de modo a permitir a continuidade no regime das normas estatais para servir de regime jurídico para as companhias que não pretendem aderir a níveis diferenciados de governança corporativa, bem como a adesão facultativa por aquelas companhias que não querem mais se submeter ao regime regulatório estatal, mas, sim, ao regime autorregulatório de governança corporativa.

Nesse sentido, Érica Gorga afirma que:

"A literatura já se debruçou sobre o fenômeno da competição entre sistemas de regulação e a possibilidade de criação de mercados para eleição da regulação aplicável nas operações com valores mobiliários. (...)

Nesta perspectiva, a iniciativa regulatória da Bovespa significou a introdução de competição no sistema de regras do mercado de capitais brasileiro, já que se pode dizer que as regras do Novo Mercado e demais segmentos passaram a competir com o sistema vigente de regulação da Lei das S.A.. A estratégia utilizada pela Bovespa foi, por isso, 
denominada de dualismo regulatório. As vantagens desse método consistem na preservação do regime anteriormente existente para as companhias que, sob a sua égide, quiserem permanecer. Desse forma, o regime novo compete diretamente com o antigo para atrair ingressantes, continuando os dois a coexistirem paralelamente." 391

A partir deste marco autorregulatório, no Brasil, há um movimento que denota um desenvolvimento do mercado de capitais, de modo que foi possível verificar um aumento das transações ocorridas no mercado de capitais brasileiros, um aumento de companhias com capital aberto que se utilizavam dos benefícios do financiamento via mercado de capitais.

O referido desenvolvimento incipiente do mercado de capitais brasileiro deve-se também, além da situação macroeconômica favorável, à atividade autorregulatória que complementou a atividade regulatória, proporcionando a elevação dos níveis de governança corporativa fundados, primordialmente, na maior transparência empresarial e na plena e completa divulgação de informações ao mercado. A propósito, este é o entendimento de Marcílio Marques Moreira:

“Já mencionamos quão relevante para o mercado foi o avanço representado pela criação da CVM. Há de registrar-se, também, o processo virtuoso pelo qual a autorregulação avançou, em paralelo ao progresso da regulação, gerando uma complementaridade e fertilização cruzada, o que evidentemente não significa a captura do regulador pelo regulado, mas sim diálogo franco e transparente entre ambos.

\section{(...)}

Passos importantes para isso foram a instituição pela Bovespa dos conceitos de Novo Mercado e Níveis Diferenciados de Governança Corporativa e a bem-sucedida autorregulação conduzida pela ANBID (Associação Nacional de Bancos de Investimentos), contribuindo tanto para aumentar o nível de transparência quanto, através de interação

${ }^{391}$ GORGA, Érica. Direito Societário Atual. Rio de Janeiro: Elsevier, 2013, p. 32 - 33. 
com o próprio regulador, para estimular processo contínuo de modernização da regulação e da autorregulação por via da legislação, marco regulatório ou acordos temáticos. "392

Embora a atividade autorregulatória tenha contribuído intensamente para a adoção de maior transparência empresarial e, consequentemente, aumentar a confiança dos investidores, que é a base de todas as relações econômicas, até o momento não se constatou um grande movimento rumo à dispersão acionária, tal como há tipicamente nos países de origem anglo-saxã, não obstante tenha havido, desde a criação dos níveis diferenciados de governança corporativa da Bovespa, um crescimento das operações de abertura de capital e do acesso ao financiamento da atividade produtiva por meio do mercado de capitais, movimento este que parece ter sofrido uma estagnação nos últimos anos.

Veja a propósito o entendimento de Érica Gorga a esse respeito:

"Embora a nova reforma da legislação societária Brasileira esteja sendo descrita como um avanço considerável, eu argumentei que este não é o caso exatamente. As reformas legais basicamente mantém o status quo $e$ improvavelmente não se destinam a melhorar o desempenho do mercado de capitais Brasileiro. As reformas legais carecem de ambição e não tratam questões-chaves que poderiam promover mudança institucional eficiente. Elas estão longe de reformas que poderiam ser possíveis em um ambiente cultural diferente." 393 (tradução livre)

\footnotetext{
${ }^{392}$ MOREIRA, Marcílio Marques. Prefácio à $2^{\mathbf{a}}$ Edição (2010) - Um Livro Revisitado: O Mercado de Capitais Brasileiro, Avanços Relevantes e Desafios à Frente. In: TRUBEK, David M.; VIEIRA, Jorge Hilário Gouvêa; SÁ, Paulo Fernandes de. Direito, Planejamento e Desenvolvimento do Mercado de Capitais Brasileiro 1965-1970. 2. ${ }^{\text {a }}$ edição. São Paulo: Saraiva, 2011, p. 17.

393 "Although the new Brazilian corporate law reform is being described as a considerable advancement, I have argued that this is not exactly the case. The legal reforms basically maintain the status quo and are not likely to improve the performance of the Brazilian capital markets. The legal reforms lack ambition and do not address the key issues that could promote efficient institutional change. They are far short of the reforms that would have been possible in a different cultural environment." (GORGA, Érica. Culture and Corporate Law Reform: A Case Study of Brazil. In: University of Pennsylvania Journal of International Economic Law, v. 27, n. ${ }^{\circ} 3, \quad 2006, \quad$ p. $903 . \quad$ Disponível el em <http://papers.ssrn.com/sol3/papers.cfm?abstract_id=999942>. Acesso em 30.06.2014)
} 
Com efeito, verificadas as empresas listadas nos segmentos Tradicional Bovespa, Bovespa Mais, Nível 1 de Governança Corporativa, Nível 2 de Governança Corporativa e Novo Mercado, de acordo com as informações disponibilizadas no site da BM\&FBovespa em 29.07.2014 ${ }^{394}$, constata-se a seguinte distribuição das companhias listadas entre os seus segmentos:

\begin{tabular}{|c|c|c|}
\hline Segmento & $\begin{array}{c}\text { Quantidade de } \\
\text { Companhias Listadas }\end{array}$ & $\begin{array}{c}\text { Distribuição das } \\
\text { Companhias Listadas nos } \\
\text { Segmentos }(\%)\end{array}$ \\
\hline Tradicional & 254 & $56,7 \%$ \\
\hline Bovespa Mais & 9 & $2,01 \%$ \\
\hline Nível 1 & 31 & $6,92 \%$ \\
\hline Nível 2 & 22 & $4,91 \%$ \\
\hline Novo Mercado & 132 & $29,46 \%$ \\
\hline Total & 448 & $100 \%$ \\
\hline
\end{tabular}

Dos dados acima indicados, constata-se que dentre os segmentos da Bovespa, o segmento Tradicional continua sendo o mais procurado pelas companhias que negociam seus valores mobiliários na Bovespa, tanto que as empresas listadas no Novo Mercado correspondem a apenas 51,97\% (cinquenta e um inteiros e noventa e sete centésimos por cento) do total de empresas listadas no segmento Tradicional e a apenas $29,46 \%$ (vinte e nove inteiros e quarenta e seis centésimos por cento) de todas as empresas listadas nos segmentos da Bovespa, sendo que os outros segmentos de níveis diferenciados

\footnotetext{
394 Informações disponíveis em <http://www.bmfbovespa.com.br/cias-listadas/empresaslistadas/BuscaEmpresaListada.aspx?Idioma=pt-br>. Acesso em 29.07.2014
} 
de governança corporativa apresentam uma procura muito pequena pelas companhias que decidem figurar entre as listadas na Bovespa.

Segundo estudos feitos por Jairo Laser Procianoy e Rodrigo S. Verdi ${ }^{395}$, as companhias que aderem aos níveis diferenciados de governança corporativa da Bovespa, têm como características principais o fato de (i) serem grandes companhias, (ii) apresentarem alta lucratividade, (iii) possuírem uma maior dispersão acionária e (iv) negociarem suas ações no mercado norte-americano por meio da emissão de American Depositary Receipt (ADR).

Tais empresas realizam uma verdadeira análise de troca entre os benefícios e os custos da adesão, sendo que a adesão aos níveis diferenciados de governança corporativa da Bovespa causa um aumento da liquidez dos valores mobiliários das empresas aderentes em comparação com as empresas listadas no segmento Tradicional Bovespa, sendo que as companhias aderentes ao Nível 2 de Governança Corporativa e ao Novo Mercado apresentam maior aumento de liquidez de seus valores mobiliários em comparação à liquidez que apresentavam antes da adesão, enquanto que as empresas aderentes ao Nível 1 de Governança Corporativa apresentam praticamente a mesma liquidez que possuíam antes da adesão.

Jairo Laser Procianoy e Rodrigo S. Verdi ${ }^{396}$ concluem que há evidências de que a recompensa auferida pela adesão das companhias aos níveis diferenciados de governança corporativa da Bovespa consiste no aumento da liquidez de seus títulos e valores mobiliários. Passados quatorze anos do lançamento dos segmentos Níveis 1 e 2 de Governança Corporativa, bem como do Novo Mercado e mais recentemente o Bovespa Mais, verifica-se, todavia, que não há um crescimento significativo das empresas aderentes a tais segmentos.

${ }^{395}$ PROCIANOY, Jairo Laser; VERDI, Rodrigo S. Adesão aos Novos Mercados da BOVESPA: Novo Mercado, Nível 1 e Nível 2 - Determintes e Consequências. In: Revista Brasileira de Finanças, v. 7, n. ${ }^{\circ}$ 1, 2009. Disponível em <http://bibliotecadigital.fgv.br/ojs/index.php/rbfin/article/viewFile/1429/799>. Acesso em 30.06.2014.

396 “Os resultados contribuem para a literatura de disclosure e de governança ao promoverem evidência de que as empresas que aderiram aos novos mercados são recompensadas com maiores n'níveis de liquidez nos seus papéis. Uma questão em aberto é porque mais empresas não aderem aos mercados de forma a beneficiarem-se com uma maior liquidez de suas ações." (PROCIANOY, Jairo Laser; VERDI, Rodrigo S. Adesão aos Novos Mercados da BOVESPA: Novo Mercado, Nível 1 e Nível 2 - Determintes e Consequências. In: Revista Brasileira de Finanças, v. 7, n. $^{\circ}$ 1, 2009, p. 132. Disponível em <http://bibliotecadigital.fgv.br/ojs/index.php/rbfin/article/viewFile/1429/799>. Acesso em 30.06.2014) 
Parafraseando Eduardo Secchi Munhoz ${ }^{397}$, embora seja cedo para fazer um prognóstico de como as companhias de capital aberto e de capital fechado comportar-seão, talvez, a resistência à adesão com a consequente dispersão das ações seja devida aos já mencionados fatores de resistência, tais como a formação histórica e econômica do Brasil, a tradição legal, os custos de transição (não só os custos de abertura do capital da companhia, mas também os custos de manutenção de altos níveis de governança corporativa), a existência de alternativas ótimas que, por si só, não estimulam a adoção de mudanças, os conflitos de interesses entre detentores de capital e não detentores de capital, bem como entre os próprios detentores de capital, que são capazes de influenciar a política econômica nacional e, consequentemente, influenciar diretamente o formato e a extensão do mercado de capitais ${ }^{398}$.

Ademais, ao rol de fatores de resistência, acrescente-se, também, a própria tradição cultural, como bem indicou Érica Gorga ${ }^{399}$, ou seja, “a existência de normas sociais fundadas numa cultura que coíba e condene comportamentos oportunistas na administração da sociedade também parece importar para o desenvolvimento de mercados de capitais fortes." 400

Dessa maneira, ainda conforme Érica Gorga ${ }^{401}$, a cultura e a ideologia podem explicar os motivos do fracasso em obter leis eficientes e efetivamente executáveis.

\footnotetext{
397 "Se é cedo para afirmar que o caminho das companhias do Novo Mercado é o da pulverização do capital, diluindo-se, portanto, a figura do acionista controlador, é mais do que tempo de reconhecer que o modelo de capital concentrado deixou de ser exclusivo. Prevalecem, no Novo Mercado, companhias com certo grau de dispersão acionária, caracterizadas pela presença de blocos de acionista com participação minoritária no capital, alguns dos quais com efetivo poder de comandar a atividade empresarial." (MUNHOZ, Eduardo Secchi. Aquisição de Controle na Sociedade Anônima. São Paulo: Saraiva, 2013, p. 106)

${ }^{398}$ Vide ROE, Mark J.. Capital Markets and Financial Politics: Preferences and Institutions. In: Oxford Handbook on Capitalism, 2011. Disponível em: < http://papers.ssrn.com/sol3/papers.cfm?abstract_id=1723331>. Acesso em 20.05.2014.

${ }^{399}$ Vide GORGA, Érica. Culture and Corporate Law Reform: A Case Study of Brazil. In: University of Pennsylvania Journal of International Economic Law, v. 27, n. ${ }^{\circ} 3$, 2006. Disponível em <http://papers.ssrn.com/sol3/papers.cfm?abstract_id=999942>. Acesso em 30.06.2014.

${ }^{400}$ GORGA, Érica. Direito Societário Atual. Rio de Janeiro: Elsevier, 2013, p. 133.

401 "In addition, this paper suggests that subjective perceptions, reflected in culture and informal constraints, play a major role in shaping patterns of firm governance, rather than just a residual influence as typically assumed. Cultural conditioning can affect the press and public perceptions so that the demand for institutional change will be constrained.

Culture and ideology can explain the failure in many countries to create efficient laws and in achieving adequate levels of enforcement. Culture can enhance the ability of interest groups to seek rents in the legislative process. Policymakers must understand that subjective perceptions vary and may be at the heart of policy implementation success or failure." (Tradução livre: "Ademais, este artigo sugere que percepções subjetivas, refletidas na cultura e coações informais, desempenham um papel importante na formatação dos padrões de governança de firma, mais que uma influência residual como tipicamente suposto. $O$
} 
No caso do Brasil, está arraigado na cultura brasileira as constantes formas de evitar punições e o cumprimento da legislação, sem que haja uma efertiva e eficaz punição, o que talvez ajude a explicar a razão pela qual, apesar da iniciativa autorregulatória, o mercado de capitais brasileiro não tenha adquirido, ainda, dimensões consideráveis.

Acrescente-se, também, a possibilidade levantada por Richard Saito e Alexandre de Miceli da Silveira ${ }^{402}$, de que a persistência da concentração acionária pode estar relacionada ao denominado efeito incentivo, que consiste no maior alinhamento de interesses entre o acionista majoritário e os demais acionistas, justamente porque o acionista controlador tem não só o interesse, mas também o poder de monitorar a administração da companhia, exigindo dos administradores a obtenção da maximização do lucro dos acionistas.

Deve-se observar, ainda com os referidos autores, que tal aspecto positivo deixa de influenciar a manutenção da concentração acionária em um grande acionista, quando houver um crescimento da possibilidade de entrincheiramento daquele grande acionista, que passará a perceber vantagens pessoais do poder de controle, mas às custas dos demais acionistas.

condicionamento cultural pode afetar as percepções da imprensa e do público de modo que a demanda por mudança institucional estará constrangida (...) Cultura e ideologia podem explicar a falha em muitos países de criar leis eficientes e em alcançar níveis adequados de execução. A cultura pode aumentar a habilidade de grupos de interesses em procurar vantagens no processo legislativo. Os políticos devem entender que percepções subjetivas variam e podem estar no coração do sucesso ou da falha na implementação de política.") (GORGA, Érica. Culture and Corporate Law Reform: A Case Study of Brazil. In: University of Pennsylvania Journal of International Economic Law, v. 27, n. ${ }^{\circ}$ 3, 2006, p. 903. Disponível em <http://papers.ssrn.com/sol3/papers.cfm?abstract_id=999942>. Acesso em 30.06.2014.)

402 "No caso brasileiro, em que a concentração das ações se dá principalmente entre os acionistas controladores e não necessariamente entre os executivos da corporação, as predições de Morck e outros (1988) e Stulz (1988) foram adaptadas da seguinte forma: a estrutura de propriedade, quando concentrada em grandes acionistas, possui um aspecto positivo (efeito incentivo), na medida em que eles possuem tanto o interesse quanto o poder para monitorarem as ações dos gestores, pressionando-os a concentrar seus esforços na maximização da riqueza dos acionistas. Entretanto, a concentração de propriedade também tem um aspecto negativo, denominado efeito entrincheiramento. Esse problema ocorreria quando, a partir de certa concentração da propriedade, os grandes acionistas passassem a perseguir a extração de benefícios privados do controle à custa dos demais investidores." (SILVEIRA, Alexandre Di Miceli da; SAITO, Richard. Governança Corporativa: Custos de Agência e Estrutura de Propriedade. In: Revista de Administração de Empresas, v. 48, n. $^{\circ} \quad 2, \quad 2008, \quad$ p. $85 . \quad$ Disponível em <http://www.scielo.br/pdf/rae/v48n2/v48n2a07.pdf>. Acesso em 30.06.2014) 
Aos prováveis fatores de resistência, acrescente-se, também, a tendência observada por Gerald F. Davis e Tracy A. Thompson ${ }^{403}$, pela qual, em virtude de suposta perda de legitimidade do sistema político (este vulnerável à influência da população prejudicada e, portanto, sujeito às influências de uma denominada "indústria de movimentos sociais" no âmbito decisório e de formulação de política) e do caráter eminentemente político do poder de controle, passaram a organizar seus interesses coletivos externamente ao âmbito deliberativo empresarial, como forma de ganharem relevância e, assim, serem considerados efetivamente no processo deliberativo.

Paralelamente ao desenvolvimento de organizações formais representativas dos interesses dos demais acionistas, há um aumento da concentração da propriedade acionária com investidores institucionais, o que, conjuntamente com o movimento social de organização de interesses dos acionistas, proporciona uma alocação mais eficiente do poder de controle nas companhias, principalmente se for considerado que houve o aumento da participação acionária por investidores institucionais, os quais evitam o desinvestimento, diante de seus ônus e das alternativas limitadas para o investimento.

\footnotetext{
403 "The political process model of social movements emphasizes the role of opportunities provided by the political climate, particularly major disruptions in the political status quo, and the role of insurgent consciousness flowing out of a shared interpretation that a political system has lost legitimacy and is vulnerable to new demands for rights from the aggrieved population (McAdam, 1982). In this situation, many formal social movement organizations commonly emerge to construct and press the movement's agendaforming a "social movement industry" (McCarthy and Zald, 1977: 121 9). Challengers, groups whose interests are not considered in the decision-making processes, seek through social movements to gain membership in the polity and thus have their interests routinely taken into account (McAdam, 1982).

(...)

Proponents of the movement argued that the system of corporate governance had lost legitimacy because the interests of shareholders were organized out of policy deliberations, and they demanded rights to greater voice in decision making, which the creation of formal organizations facilitated." (Tradução livre: "O modelo político de movimentos sociais enfatiza o papel de oportunidades fornecidas pelo clima político, particularmente importantes roturas no status quo politico, e o papel de consciência insurgente derivada de uma interpretação compartilhada, no sentido de que o sistema político perdeu legitimidade e está vulnerável a novas demandas por direitos da população lesada (McAdam, 1982). Nesta situação, muitas organizações formais de movimento social comumente emergem para construir e pressionar a pauta do movimento formando uma "indústria de movimento social" (McCarthy e Zald, 1977: 1219). Grupos desafiadores, cujos interesses não são considerados no processo de formação decisória, procuram por meio de movimentos sociais ganhar membros na política e assim ter seus interesses rotineiramente levados em conta (McAdam, 1982) (...)Proponentes do movimento argumentam que o sistema de governança corporativa perdeu sua legitimidade, pois os interesses dos acionistas foram organizados fora das deliberações políticas, e eles demandaram direitos para engrandecer a voz no processo decisório, no que a criação de organizações formais facilitou.") (DAVIS, Gerald F.; THOMPSON, Tracy A.. A Social Movement Perspective on Corporate Control. In: Administrative Science Quarterly, v. 39, nº 1, 1994, p. 152 a p. 153. Disponível em < http://webuser.bus.umich.edu/gfdavis/Papers/A\%20Social\%20Movement.pdf>. Acesso em 09.06.2013)
} 
Portanto, pode-se concluir que além dos inúmeros fatores de resistência à mudança de um sistema de capital concentrado para um sistema de capital disperso, como indicado anteriormente, dentre os quais, inclusive a própria regulação ${ }^{404}$ enquanto resultado de influências políticas, tendo em vista que as companhias, segundo, Colin Mayer ${ }^{405}$, são o resultado de inúmeras combinações entre a propriedade acionária e os direitos de controle, cuja proporção varia durante todo o ciclo de existência da empresa e também entre os diversos países, não há como se ter uma previsão de qual rumo o mercado de capitais tomará, seja em direção à dispersão acionária, seja em direção à manutenção da concentração acionária.

Isto ocorre também porque, segundo estudo de Carlin e Mayer, a relação entre sistemas financeiros, sistemas de direito societário e os tipos de atividade econômica possui inúmeras implicações na política, de modo a inexistir um sistema financeiro e de direito societário que sejam predominantes, que sejam adequados a todos os tipos de economia ou de indústrias dentro de uma economia, isto é, nas palavras de Carlin e Mayer "o que é correto para uma economia desenvolvida, pode ser inapropriado para outra em desenvolvimento. O que é apropriado para uma economia intensa e inovativa em pesquisa e desenvolvimento tecnológicos, pode ser inapropriado para uma economia mais imitativa. Pode haver importantes trocas ao combinar sistemas com as bases industriais dos países e seus estágios de desenvolvimento econômico e de políticas regulatórias e legais em

\footnotetext{
404 "Regulation has affected the entire pattern and distribution of corporate control in all countries. As a general proposition, we believe that control is concentrated in forms in which regulation confers particular advantages: shareblocks are concentrated at levels at which are significant control benefits" (Tradução livre: "A regulação afetou todo o padrão e a distribuição do controle corporativo em todos os países. Como uma proposição geral, nós acreditamos que o controle é concentrado em formas que a regulação confere vantagens específicas: blocos de ações são concentrados em níveis que proporcionem significativos beneficios do controle.") (BECHT, Marco \& MAYER, Colin. Corporate Control in Europe. In: ULB Université Libre de Bruxelles Institutional Repository, 2013/13338, 2000, p. 18. Disponível em <http://economics.ouls.ox.ac.uk/11439/1/ccineurope.pdf>. Último acesso em 09.06.2013.)

405 "There are two lessons. Firstly, firms are diverse combinations of ownership and control rights and the proportions in which these are combined together differ appreciably across the life cycle of firms. Secondly, the life cycle development of ownership and control of firms differs across countries." (Tradução livre: "Há duas lições. Primeiramente, firmas são diversas combinações de propriedade e de direitos decorrentes do controle e as proporções nas quais elas são combinadas difere apreciavelmente durante o ciclo de vida das firmas. Segunda, o ciclo de vida do desenvolvimento da propriedade e dos direitos decorrentes do controle das firmas difere entre os países.") (MAYER, Colin. Ownership Matters. Disponível em <ftp://ns1.ystp.ac.ir/YSTP/1/1/ROOT/DATA/PDF/unclassified/OWNERSHIPMATTERS.PDF>, $\quad$ p. 7. Último acesso em 29.07.2014.)
} 
direção aos sistemas financeiro e corporativo, as quais precisam ser sensíveis a estes impactos nas atividades corporativas." 406

406 "What is right for a developed economy may be quite inappropriate for a developing one. What is suited to an innovative $R \& D$ intensive economy may be ill-suited to a more imitative one. There may be important trade-offs in matching systems with the industrial bases of countries and their stages of economic development and regulatory and legal policies towards financial and corporate systems need to be sensitive to these potential impacts on corporate activities." (CARLIN, Wendy; MAYER, Colin. How Do Financial Systems Affect Economic Performance? Disponível em < http://web.cenet.org.cn/upfile/88820.pdf>, p. 25 a p. 26. Acesso em 29.07.2014.) 


\section{O EXERCÍCIO DO PODER DE CONTROLE NAS COMPANHIAS DE CAPITAL ABERTO NO BRASIL}

Segundo estudo feito por Jairo Laser Procianoy e Rodrigo S. Verdi ${ }^{407}$, as companhias que decidem aderir aos níveis diferenciados de governança corporativa da Bovespa visam $(i)$ à negociação de seus valores mobiliários em um ambiente estimulador dos investidores e (ii) à valorização da companhia e, consequentemente, de seus valores mobiliários ao adotarem melhores práticas de governança corporativa e, assim, ampliarem os direitos dos acionistas minoritários e aumentarem a quantidade e a qualidade das informações, isto porque, ao aderirem aos níveis mais avançados de governança corporativa, sob a ótica dos investidores, há uma maior credibilidade oferecida ao mercado, que, por sua vez, aumenta sua confiança na companhia aderente, aumentando, portanto, a disposição do investidor em adquirir as ações daquela companhia, inclusive, a um preço maior, o que, sob o ângulo da companhia, acaba por reduzir-lhe os custos de obtenção de recursos via mercado de capitais, se comparados com os custos que teria na obtenção de recursos em seu segmento de origem.

Além disso, há um aumento da liquidez de seus valores mobiliários em comparação à liquidez que apresentavam antes da adesão aos níveis diferenciados de governança corporativa da Bovespa, apresentando, inclusive, as empresas que aderiram ao Nível 1, ao Nível 2 e ao Novo Mercado, respectivamente, uma redução de 12\% (doze por cento), $25 \%$ (vinte e cinco por cento) e $37 \%$ (trinta e sete por cento) nos dias em que tais empresas não obtêm retorno na negociação de suas ações, bem como uma redução de $14 \%$ (quatorze por cento), $24 \%$ (vinte e quatro por cento) e $40 \%$ (quarenta por cento) nos dias em que as referidas empresas não efetivam transações com seus valores mobiliários, em comparação às demais companhias com valores mobiliários negociados no segmento tradicional da Bovespa.

\footnotetext{
${ }^{407}$ PROCIANOY, Jairo Laser; VERDI, Rodrigo S. Adesão aos Novos Mercados da BOVESPA: Novo Mercado, Nível 1 e Nível 2 - Determintes e Consequências. In: Revista Brasileira de Finanças, v. 7, n. 1 , 2009. Disponível em <http://bibliotecadigital.fgv.br/ojs/index.php/rbfin/article/viewFile/1429/799>. Acesso em 30.06.2014.
} 
A maior valorização da empresa e a atribuição de maior confiabilidade e credibilidade devem-se à redução da assimetria de informação entre acionistas e administradores, à redução das possibilidades de obtenção, pelo acionista controlador, de vantagens pessoais extraídas do poder de controle em detrimento dos demais acionistas.

Ainda, conforme Jairo Laser Procianoy e Rodrigo S. Verdi, dentro da amostragem feita ${ }^{408}$, de todas as ações das empresas que aderiram aos níveis diferenciados de governança corporativa da Bovespa (Níve1, Nível 2 e Novo Mercado), somente 27,96\% (vinte e sete inteiros e noventa e seis centésimos por cento), em média, são de titularidade dos acionistas minoritários, sendo que, na mesma amostragem, encontrou-se uma dispersão máxima de $84,20 \%$ (oitenta e quatro inteiros e vinte centésimos por cento).

Em outro estudo com uma amostragem mais ampla, Dante Mendes Aldrighi e Roberto Mazzer Neto ${ }^{409}$, no ano de 2001, analisaram 602 (seiscentas e duas) companhias de capital aberto que forneceram o Informativo Anual (IAN) para a Comissão de Valores Mobiliários. Os autores constataram que, em termos de titularidade de ações votantes, há uma grande concentração acionária nas companhias de capital aberto brasileiras, de modo que, em $83,39 \%$ (oitenta e três inteiros e trinta e nove centésimos por cento) das companhias abertas, o acionista controlador detém mais de 50\% (cinquenta por cento) das ações com direito a voto, sendo que somente em $0,17 \%$ (dezessete centésimos por cento) das companhias o acionista controlador detém até 10\% (dez por cento) das ações com direito de voto. E, em 4,32\% (quatro inteiros e trinta e dois centésimos por cento) das companhias o controlador detém de $10,01 \%$ (dez inteiros e um centésimo por cento) a $20 \%$ (vinte por cento) das ações com direito de voto e, por fim, em 12,13\% (doze inteiros e treze centésimos por cento) das companhias seu acionista controlador detém ações com direito a voto equivalentes a 20,01\% (vinte inteiros e um centésimo por cento) a $50 \%$ (cinquenta por cento).

\footnotetext{
${ }^{408}$ PROCIANOY, Jairo Laser; VERDI, Rodrigo S. Adesão aos Novos Mercados da BOVESPA: Novo Mercado, Nível 1 e Nível 2 - Determintes e Consequências. In: Revista Brasileira de Finanças, v. 7, n. ${ }^{\circ}$, 2009, p. 117. Disponível em <http://bibliotecadigital.fgv.br/ojs/index.php/rbfin/article/viewFile/1429/799>. Acesso em 30.06.2014.

409 ALDRIGHI, Dante Mendes; MAZZER NETO, Roberto. Estrutura de Propriedade e de Controle das Empresas de Capital Aberto no Brasil. In: Revista de Economia Política, v. 25 n. 2 (98), 2005. Disponível em <http://www.scielo.br/pdf/rep/v25n2/a09v25n2>. Acesso em 30.06.2014.
} 
Dessa forma, os 83,39\% (oitenta e três inteiros e trinta e nove centésimos por cento) das companhias abertas com concentração acionária superior a 50\% (cinquenta por cento) apresentam, em média, a congregação de $85,68 \%$ (oitenta e cinco inteiros e sessenta e oito centésimos por cento) do direito de voto, sendo que, nos 16,61\% (dezesseis inteiros e sessenta e um centésimos por cento) das companhias com concentração acionária inferior a 50\% (cinquenta por cento), o acionista controlador concentra em média 33,07\% (trinta e três inteiros e sete centésimos por cento) do direito de voto.

Ainda, de acordo com o estudo de Dante Mendes Aldrighi e Roberto Mazzer Neto acima mencionado, os números indicados no parágrafo anterior consideram os acordos de acionistas celebrados para a garantia do poder de controle. Mas, mesmo não se considerando os acordos de acionistas celebrados para aquele fim, a concentração acionária, nas companhias brasileiras de capital aberto, continua sendo alta, pois o acionista controlador detém, em média, o equivalente a 69,05\% (sessenta e nove inteiros e cinco centésimos por cento) das ações com direito de voto.

Observe-se que, da amostra utilizada por Dante Mendes Aldrighi e Roberto Mazzer Neto, em $15 \%$ (quinze por cento) das companhias, os acionistas celebraram acordos de acionistas, sendo que em 10,80\% (dez inteiros e oitenta centésimos por cento) das companhias da amostra, o poder de controle é estabelecido por meio de acordo de acionistas, o qual, em média, resulta em na detenção de um poder de controle que congrega a titularidade de $83,77 \%$ (oitenta e três inteiros e setenta e sete centésimos por cento) de ações com direito de voto.

Dentre outros mecanismos utilizados para garantir uma maior concentração de titularidade de ações com direito a voto, o estudo de Dante Mendes Aldrighi e Roberto Mazzer Neto indica que, da amostragem considerada, 68,11\% (sessenta e oito inteiros e onze centésimos por cento) das companhias utilizam o esquema piramidal para assegurar o poder de controle, 66,94\% (sessenta e seis inteiros e noventa e quatro centésimos por cento) utilizam a emissão de ações preferenciais como forma de garantir a concentração acionária e, portanto, o poder de controle e, por fim, apenas 1,16\% (um inteiro e dezesseis centésimos por cento) das companhias da amostragem utilizam o mecanismo de 
participação cruzada para garantir a concentração acionária e consequentemente o poder de controle.

Não obstante os méritos dos estudos já desenvolvidos, tais como os citados acima, faz-se necessário observar que, como bem indicaram Alexandre Di Miceli da Silveira e Richard Saito, "até o momento não se chegou a modelos com fundamentação teórica segura que incluíssem prescrições para decisões ótimas acerca de temas-chave em governança corporativa, como estrutura de capital, remuneração dos gestores, políticas de investimento, disclosure e conselho de administração."410

Além disso, como ressaltaram Marco Becht e Colin Mayer ${ }^{411}$, geralmente os estudos acerca da propriedade acionária e o poder de controle possuem uma amostragem limitada, pois, por exemplo, analisam uma porção das maiores companhias de dado país, de forma a não incluírem boa parte das companhias, além de analisarem apenas os direitos de votos, embora o poder de controle seja muito mais abrangente que os direitos de voto e muito mais complexo.

Ademais, o modelo de sociedade por ações com capital disperso pode vir a ser um novo modelo a ser adotado pelas companhias brasileiras, o que não é possível saber por se tratar de fenômeno recente no Brasil, de modo que, com bem ressaltou Heloisa Belotti Bedicks em seu estudo sobre governança corporativa e dispersão de capital, "não

${ }^{410}$ SILVEIRA, Alexandre Di Miceli; SAITO, Richard. Governança Corporativa: Custos de Agência e Estrutura de Propriedade. In: Revista de Administração de Empresas, v. 48, n. ${ }^{\circ}$ 2, 2008, p. 85. Disponível em <http://www.scielo.br/pdf/rae/v48n2/v48n2a07.pdf>. Acesso em 30.06.2014.

411 "Interesting though these studies are, they both have serious methodological problems. Firstly, the coverage of the studies is very limited (...) Secondly, the analysis of control in both papers is rudimentary. In fact, though both papers refer to ownership, what they actually measure is voting control. Data on ownership are in general not available and all that can be measured is voting rights. More significantly, an analysis of control of corporations is complex." (Tradução livre: "Embora sejam interessantes estes estudos, ambos possuem problemas metodológicos sérios. Primeiramente, a abrangência dos estudos é muito limitada (...) Segundo, a análise do controle em ambos artigos é rudimentar. De fato, embora ambos os artigos sejam relativos à propriedade, o que eles realmente medem é o direito de voto. Os dados sobre propriedade em geral não estão disponíveis e tudo o que pode ser medido são os direitos de voto.”) (BECHT, Marco; MAYER, Colin. Corporate Control in Europe. In: ULB - Université Libre de Bruxelles Institutional Repository, 2013/13338, 2000, $\quad$ p., $\quad 3 . \quad$ Disponível $\quad \mathrm{em}$ <http://economics.ouls.ox.ac.uk/11439/1/ccineurope.pdf>. Acesso em 09.06.2013) 
ficou claro se essa opção se tornou viável apenas por um momento de certa 'euforia' ou se por uma janela do mercado" ${ }^{412}$, o que exigirá observação e estudos no decorrer do tempo.

Contudo, dos estudos analisados e citados, percebe-se que, mesmo com a criação dos níveis diferenciados de governança corporativa da Bovespa, as companhias abertas brasileiras listadas nos segmentos da Bovespa ainda apresentam uma alta concentração acionária, de forma que, ainda que seja imposto um free float mínimo de $25 \%$ (vinte e cinco por cento), o acionista controlador continua mantendo uma alta participação por meio de ações com direito de voto, seja individualmente, seja por meio da celebração de acordo de acionistas como forma de garantir a detenção e o efetivo exercício do poder de controle.

Esta situação parece aproximar-se muito da situação encontrada na Europa continental $^{413}$, segundo a qual, geralmente, há um acionista detentor de um bloco de ações suficientes para garantir-lhe dominação na companhia e o controle do direito de voto, além da inexistência de outros blocos de acionistas com participações significantes, que possam ameaçar o domínio e controlem daquele acionista majoritário, que via de regra é constituído por famílias ou por companhias, que se utilizam de mecanismos dissociadores da propriedade acionária e o direito ao fluxo de caixa.

Assim, no Brasil, mesmo nas companhias de capital aberto em que há uma redução da concentração da titularidade de ações com direito de voto pelo acionista controlador, este procura obter uma reconcentração por meio da celebração de acordo de acionistas $^{414}$, de modo a garantir-lhe a organização de bloco de ações estável e, portanto, assegurar-lhe a detenção do poder de controle, como bem reconheceu Érica Gorga:

${ }^{412}$ BEDICKS, Heloisa Belotti. Governança Corporativa e Dispersão de Capital: Múltiplos Casos no Brasil. São Paulo: Saint Paul: 2009, p. 151.

${ }^{413}$ Vide BECHT, Marco; MAYER, Colin. Corporate Control in Europe. In: ULB - Université Libre de Bruxelles Institutional Repository, 2013/13338, 2000, p. 9 - 15 . Disponível em <http://economics.ouls.ox.ac.uk/11439/1/ccineurope.pdf>. Acesso em 09.06.2013.

414 "O acordo de acionistas é instrumento utilizado por boa parte das companhias listadas no Novo Mercado, como apontado no estudo de GORGA (2009). Por meio dele, é possível organizar de forma estruturada o bloco de acionistas, para exercício do poder de controle. Isso porque, no Brasil, o acordo de acionistas (...) tornou-se mais do que um simples contrato entre acionistas, para transformar-se numa autêntica instância da estrutura de poder da companhia." (MUNHOZ, Eduardo Secchi. Aquisição de Controle na Sociedade Anônima. São Paulo: Saraiva, 2013, p. 108) 
"A estrutura de propriedade acionária das companhias abertas brasileiras é muito concentrada, como demonstram diversos estudos existentes sobre o tema. As companhias são, tradicionalmente, controladas por um acionista controlador majoritário, ou, como se verificou mais recentemente, em razão de maior grau de dispersão das estruturas de propriedade das companhias listadas no Novo Mercado, por um grupo de acionistas vinculados por acordo de acionistas que regula o exercício do controle compartilhado. ${ }^{415}$

Além do acordo de acionistas, outros mecanismos também são utilizados como medidas defensivas do poder de controle ${ }^{416}$, tais como as denominadas poison pills, a estrutura de propriedade acionária piramidal, a posse cruzada de ações, o uso de procurações para o exercício do direito de voto, além da tradicional emissão de ações preferenciais, como forma de dissociar a propriedade acionária do exercício do direito de voto $^{417}$, permitindo, ainda, a detenção do poder de controle com um menor investimento de capital pelo acionista controlador, em razão do desvio proporcionado entre o direito de voto e o direito de fluxo de caixa existente nas companhias de capital aberto brasileiras.

\footnotetext{
${ }^{415}$ GORGA, Érica. Direito Societário Atual. Rio de Janeiro: Elsevier, 2013, p. 41 - 42.

416 "No plano jurídico, o declínio da concentração da propriedade acionária nas sociedades brasileiras gerou inúmeras consequências significativas, tais como o recurso à celebração de tais acordos de acionistas, a adoção de certos mecanismos de defesa contra supostas tomadas hostis de controle, a prática do exercício do direito de voto por meio de procurações (...)." (Idem, ibidem, p. 12)

417 "De fato, há um amplo reconhecimento de que nos países em desenvolvimento e na Europa continental o potencial de expropriação dos minoritários pelos controladores constitui o principal problema de agência, implicando custos que excederiam os benefícios que a concentração da propriedade e do controle poderia acarretar em termos de monitoramento e de custos de transação. La Porta et al. (1999) e Roe (1998) atribuem as diferenças internacionais na estrutura de propriedade e de controle das empresas essencialmente ao grau efetivo de proteção legal dos acionistas minoritários: nos países em que a legislação é deficiente elou seu enforcement é insatisfatório, essa estrutura tenderia a ser mais concentrada. Essa proteção legal inadequada pode se manifestar pela facilidade com que se alavanca o poder de voto em relação à propriedade de capital. Embora possa estimular o monitoramento sem que se comprometa a liquidez das ações, o afastamento da regra da uma-ação-um-voto fornece aos grandes acionistas, em contrapartida, incentivos e poder para obterem ganhos privados à custa dos minoritários (Becht, 1999). Entre os recursos que facultam o descolamento entre direitos de voto e de propriedade, destacam-se: (1) a emissão de ações preferenciais sem direito a voto; (2) os direitos de voto por procuração; (3) a posse cruzada de ações, que pode favorecer "cartéis de votos" ineficientes, pelos quais as equipes de diretores que os articulam votam a favor uma das outras nas assembléias respectivas; (4) os acordos de voto entre detentores de blocos de ações; e (5) os esquemas-pirâmide (Aldrighi, 2000)." (ALDRIGHI, Dante Mendes; MAZZER NETO, Roberto. Estrutura de Propriedade e de Controle das Empresas de Capital Aberto no Brasil. In: Revista de Economia Política, v. 25 n. 2 (98), 2005, p. 116 a p. 117. Disponível em <http://www.scielo.br/pdf/rep/v25n2/a09v25n2>. Acesso em 30.06.2014.)
} 
Apesar da predileção de boa parte da doutrina nacional e internacional em afirmar que se chegará a um momento em que o acionista controlador não existirá mais ${ }^{418}$, em razão da alta dispersão acionária que as companhias possivelmente atingirão, parecenos que, além dos já mencionados fatores de resistência que impedem ou, pelo menos, dificultam a dispersão acionária e o desenvolvimento do mercado de capitais, no caso brasileiro, há a incidência do que Alexandre Di Miceli da Silveira e Richard Saito ${ }^{419}$ denominaram de efeito incentivo decorrente da concentração acionária existente em relação ao acionista controlador, visto que o mesmo, enquanto detiver uma participação que não lhe permita entrincheirar-se, apresentará um maior alinhamento de interesses com os interesses dos demais acionistas.

Isto quer dizer que o acionista controlador terá, tal como os demais acionistas, interesse e poder de monitorar a gestão da companhia, de modo a obter a maximização do lucro em benefício de todos os acionistas. A partir do momento em que a concentração acionária permitir ao acionista controlador o seu entrincheiramento, incidirá o denominado aspecto negativo, visto que o acionista controlador passará a visar à obtenção de vantagens pessoais às custas dos demais acionistas.

Nesse sentido, vejam as afirmações de Alexandre Di Miceli da Silveira e Richard Saito, in verbis:

"No caso brasileiro, em que a concentração das ações se dá principalmente entre os acionistas controladores e não necessariamente entre os executivos da corporação, as predições de Morck e outros (1988) e Stulz (1988) foram adaptadas da seguinte forma: a estrutura de propriedade, quando concentrada em grandes acionistas, possui um aspecto positivo (efeito incentivo), na medida em que eles possuem tanto $o$ interesse quanto o poder para monitorarem as ações dos gestores, pressionando-os a concentrar seus esforços na maximização da riqueza dos acionistas. Entretanto, a concentração de propriedade também tem

\footnotetext{
${ }^{418}$ Vide, por exemplo: CARVALHOSA, Modesto. A Dispersão Acionária e o Desaparecimento da Figura do Controlador. In: ROVAI, Armando Luiz; MURRAY NETO, Alberto. As Sociedades por Ações na Visão Prática do Advogado. Rio de Janeiro, Elsevier, 2010.

${ }^{419}$ SILVEIRA, Alexandre Di Miceli; SAITO, Richard. Governança Corporativa: Custos de Agência e Estrutura de Propriedade. In: Revista de Administração de Empresas, v. 48, n. ${ }^{\circ}$ 2, 2008. Disponível em $\langle$ http://www.scielo.br/pdf/rae/v48n2/v48n2a07.pdf >. Acesso em 30.06.2014.
} 
um aspecto negativo, denominado efeito entrincheiramento. Esse problema ocorreria quando, a partir de certa concentração da propriedade, os grandes acionistas passassem a perseguir a extração de benefícios privados do controle à custa dos demais investidores."

Acrescente-se, ainda, que, no Brasil, observa-se uma intensa intervenção estatal desde os primórdios do sistema financeiro nacional brasileiro, sendo que sempre houve pouco espaço para a atuação independente dos agentes privados em relação ao poder estatal, estando os agentes privados intensamente sujeitos à coordenação estatal, o que, segundo John C. Coffee $\mathrm{Jr}^{421}$, proporciona um ambiente pouco propício à dispersão acionária. A existência de um ambiente dotado de alto grau de coordenação independente dos agentes privados teria o condão de possibilitar um movimento de dispersão, mas que, em um segundo momento, dependeria da existência de normas jurídicas estatais protetoras de investidores, fomentando a continuidade desse movimento.

Todavia, é necessário frisar que, além das normas autorregulatórias e regulatórias favoráveis ao movimento de dispersão acionária, há inúmeros outros fatores que também determinam o formato do mercado de capitais e sua extensão, de maneira que "a evolução do mercado de capitais depende também de outros fatores que não são diretamente controláveis ou condicionáveis pelo Direito." 422

Portanto, como visto anteriormente, o modelo de sociedade por ações com capital disperso não parece ser a espécie societária em seu mais alto grau de evolução como pregavam Adolf Augustus Berle Jr. e Gardiner C. Means, tampouco que necessariamente o mercado de capitais dos países deva atingir um alto grau de evolução com a concomitante dispersão acionária das companhias, tanto que se trata de modelo muito pouco utilizado no mundo.

\footnotetext{
${ }^{420}$ SILVEIRA, Alexandre Di Miceli; SAITO, Richard. Governança Corporativa: Custos de Agência e Estrutura de Propriedade. In: Revista de Administração de Empresas, v. 48, n. ${ }^{\circ}$ 2, 2008, p. 85. Disponível em <http://www.scielo.br/pdf/rae/v48n2/v48n2a07.pdf>. Acesso em 30.06.2014.

${ }^{421}$ COFFEE JR., John C.. The Rise of Dispersed Ownership : the Roles of Law and the State in the Separation of Ownership and Control. In: Yale Law Journal, v. 111, 2001. Disponível em <http://yalelawjournal.org/images/pdfs/455.pdf>. Acesso em 29.07.2012.

${ }^{422}$ GORGA, Érica. Direito Societário Atual. Rio de Janeiro: Elsevier, 2013, p. 132.
} 
O que parece restar claro é que o desenvolvimento do mercado de capitais é um processo complexo, que depende de diversos fatores, que nem sempre são passíveis de controle jurídico por meio da edição de normas estatais ou autorregulatórias, como, por exemplo, o influxo de influências que a política econômica sofre, a qual, por sua vez, influencia o formato e a extensão do mercado de capitais.

Consequentemente, a estrutura de propriedade acionária também fica sujeita ao influxo de diversos fatores, de forma que a iniciativa autorregulatória privada não é suficiente para proporcionar uma desconcentração da propriedade acionária. 


\section{SÍNTESE CONCLUSIVA}

Mesmo tendo, a sociedade por ações, apresentado uma evolução históricolegislativa, culminando com seu atual modelo voltado para a macroempresa, dos estudos analisados, verifica-se que o modelo caracterizado por Adolf Augustus Berle Jr e Gardiner C. Means não é o último grau de evolução daquela modalidade societária, tampouco tem sua utilização difundida no âmbito mundial.

Ao contrário do que se poderia imaginar, a modalidade de sociedade por ações com maior uso difundido no mundo é a sociedade por ações com concentração de capital, o que nos faz indagar se realmente a dispersão do capital deveria ser considerada o grau mais evoluído das sociedades por ações.

Talvez, devêssemos ter em mente que de acordo com as peculiaridades econômicas, políticas, jurídicas e sociais de cada país, as empresas que adotam a modalidade de sociedade por ações acabam por encontrar sua eficiência dentro da modalidade mais utilizada, sem que haja necessariamente um movimento rumo à dispersão acionária, de modo que não se pode estabelecer uma relação direta entre a dispersão acionária e a maior eficiência da empresa constituída sob a modalidade de sociedade por ações.

No que se refere ao desenvolvimento do mercado de capitais, ainda não há estudos conclusivos que estabeleçam uma relação direta entre seu desenvolvimento e o desenvolvimento econômico do país, embora haja evidências nesse sentido. De igual modo, não se sabe conclusivamente se a poupança estimula o desenvolvimento do mercado de capitais ou o desenvolvimento deste estimula a poupança para investimento direto na atividade produtiva.

Dos estudos analisados, pode-se constatar que o mercado de capitais tem sua forma e extensão determinados por inúmeros fatores, tais como a política econômica do país, a influencia dos interesses prevalecentes na formulação da política econômica, os 
interesses das elites, a formação econômica do país, a dependência da trajetória históricolegal das instituições formais, os custos de transição, as normas sociais vigentes etc.

Não se trata, portanto, de obter o desenvolvimento do mercado de capitais somente com a atribuição de maiores direitos aos acionistas minoritários, pois a formatação daquele mercado depende de vários outros fatores, inclusive, da maior liberdade de ação dos agentes privados em termos de independência em relação ao poder estatal.

Viu-se que o Brasil herdou de Portugal o modelo estatal interventor desde a época Colonial, intervenção esta que também influencia os aspectos do mercado de capitais. Assim, mesmo tendo havido uma recente atuação autorregulatória da Bovespa, pode-se perceber que as companhias brasileiras não atingira o nível de dispersão acionária norte-americana, tampouco o mercado de capitais apresentou um extremo desenvolvimento.

Logo, ainda não há estudos suficientes para se prever qual rumo as companhias brasileiras tomarão, tampouco qual aspecto o mercado de capitais brasileiro assumirá, o que somente poderá ser respondido após o transcurso do tempo e a realização de estudos. 


\section{BIBLIOGRAFIA}

ABRAÃO, Eduardo Lysias Maia. Acordo de Acionistas Típicos e Atípicos. Curitiba: Juruá, 2011.

ALDRIGHI, Dante Mendes; MAZZER NETO, Roberto. Estrutura de Propriedade e de Controle das Empresas de Capital Aberto no Brasil. In: Revista de Economia Política, v. 25 n. 2 (98), 2005. Disponível em <http://www.scielo.br/pdf/rep/v25n2/a09v25n2>. Acesso em 30.06.2014.

ALVES, Joamir Müller Romiti Alves. A Introdução do Conceito de 'Influência Significativa' na Lei das S.A. Representa a Introdução do Controle Externo no Direito Brasileiro?. In: ZANETTI, Andrea; FEFERBAUM, Marina. Direito dos Negócios em Debate. São Paulo: Saraiva, 2011.

AMERICAN LAW INSTITUTE. Principles of Corporate Governance: Analysis and Recommendations. Disponível em

<http://www.ali.org/index.cfm?fuseaction=publications.ppage\&node_id=88>

ANDRADE FILHO, Sérgio Teixeira. Organização do Controle Societário na Sociedade Familiar. São Paulo: Almedina, 2012.

ARANHA, Maria Lúcia de Arruda \& MARTINS, Maria Helena Pires. Filosofando: Introdução à Filosofia. São Paulo: Moderna, 1991.

ARRUDA, Maria Clara da Silveira Villasbôas. Companhia Aberta x Companhia Fechada. In Revista de Direito Mercantil. São Paulo: Revista dos Tribunais, Ano XXVI, n. ${ }^{\circ} 65$, Jan-Mar/1987.

ASCARELli, Tullio. Problemas das Sociedades Anônimas e Direito Comparado. Campinas: Bookseller, 2001. 
Iniciação ao Estudo do Direito Mercantil. Sorocaba: Minelli, 2007.

ASQUINI, Alberto. Profili dell'impresa. Tradução de Fábio Konder Comparato. In Revista de Direito Mercantil. São Paulo: Revista dos Tribunais, Ano XXXV, n. ${ }^{\circ} 104$, OutDez/1996.

ATALIBA, Geraldo. Sistema Constitucional Tributário Brasileiro. São Paulo: Revista dos Tribunais, 1968.

BARBOSA, Henrique Cunha. A Exclusão do Acionista Controlador na Sociedade Anônima. Rio de Janeiro: Elsevier, 2009.

BARROS, Benedicto Ferri. Mercado de Capitais e ABC de Investimentos. São Paulo: Atlas, 1967.

BARROS, José Roberto Mendonça de et al. Desafios e Oportunidades para o Mercado de Capitais Brasileiro. São Paulo: Bovespa, 2000. Disponível em < http://www.bmfbovespa.com.br/Pdf/mercado_capitais_desafios.pdf>. Acesso em 10.02.2013.

BARTHÉLÉMY, Jacques; COULON, Nicolas; EGAL, Jacques ; GUIGOU, Hubert; HARDOUIN, Michel ; MELLO, Xavier de; PETITEAU, Gérard \& SEURAT, Patrick. Le Droit des Groupes de Sociétés. Paris : Dalloz, 1991.

BECHT, Marco ; MAYER, Colin. Corporate Control in Europe. In: ULB - Université Libre de Bruxelles Institutional Repository, 2013/13338, 2000. Disponível em <http://economics.ouls.ox.ac.uk/11439/1/ccineurope.pdf>. Acesso em 09.06.2013.

BEDICKS, Heloisa Belotti. Governança Corporativa e Dispersão de Capital: Múltiplos Casos no Brasil. São Paulo: Saint Paul, 2009. 
BERLE Jr., Adolf Augustus; MEANS, Gardiner C. A Moderna Sociedade Anônima e a Propriedade Privada. 3. a edição. São Paulo: Nova Cultural, 1988.

BERTOLDI, Marcelo M.. O Poder de Controle na Sociedade Anônima - Alguns Aspectos. In Revista de Direito Mercantil. São Paulo: Revista dos Tribunais, Ano XXXIX, n. ${ }^{\circ} 118,2000$.

BETTARELlO, Flávio Campestrin. Governança Corporativa - Fundamentos Jurídicos e Regulação. São Paulo: Quartier Latin, 2008.

BOBBIO, Norberto. Estado, Governo, Sociedade para Uma Teoria Geral da Política. $1^{\mathrm{a}}$ edição. $18^{\mathrm{a}}$ Reimpressão. Rio da Janeiro: Paz e Terra, 2012.

BRUNETTI, Antonio. Trattato del diritto delle società. Vol. I. Milano: Giuffrè, 1948.

BRASSEUL, Jacques. História Econômica do Mundo: Das Origens aos Subprimes. $2^{\text {a }}$ edição. Lisboa: Edições Texto \& Grafia, 2010.

CARDOSO, Eliana A. Economia Brasileira ao Alcance de Todos. 14. ${ }^{a}$ edição. São Paulo: Brasiliense, 1993.

CARLIN, Wendy; MAYER, Colin. How Do Financial Systems Affect Economic Performance? Disponível em < http://web.cenet.org.cn/upfile/88820.pdf $>$. Acesso em 29.07.2014.

CARVAlHO, Ney. A Saga do Mercado de Capitais no Brasil. São Paulo: Saint Paul, 2014.

CARVAlHO, Paulo de Barros. Direito Tributário: Fundamentos Jurídicos da Incidência. 2. ${ }^{a}$ edição. São Paulo: Saraiva, 1999.

CARVAlHOSA, Modesto. Comentários à Lei das Sociedades Anônimas. Vols. 1. ${ }^{\circ},{ }^{\circ}{ }^{\circ}$ e 4. ${ }^{\circ}$, Tomo II. 6. ${ }^{\mathrm{a}}$, 5. $^{\mathrm{a}}$ e 4. ${ }^{\mathrm{a}}$ edições. São Paulo: Saraiva, 2011. 
. Acordo de Acionistas. São Paulo: Saraiva, 2011.

; EIZIRIK, Nelson. A Nova Lei das S/A. São Paulo: Saraiva,

2002.

. A Dispersão Acionária e o Desaparecimento da Figura do

Controlador. In: ROVAI, Armando Luiz; MURRAY NETO, Alberto. As Sociedades por Ações na Visão Prática do Advogado. Rio de Janeiro, Elsevier, 2010.

A Nova Lei das Sociedades Anônimas - Seu Modelo

Econômico. 2. ${ }^{\text {a }}$ edição. Rio de Janeiro: Paz e Terra, 1977.

CHAMPAUD, Claude. Le Pouvoir de Concentration de la Société par Actions. Paris: Sirey, 1962.

\& PILLUSSEAU, Jean. L'Enterpirse et le Droit Commercial.

Paris : Armand Colin, 1970.

CHARLESWORTH, John; CAIN, Thomas Ewan; MORSE, Geoffrey; MARSHALL, Enid A.; MORRIS, Richard Colin. Company Law. 10ª edição. Londres: Stevens \& Sons, 1972.

CHEDIAK, Julian Fonseca Peña. A Reforma do Mercado de Valores Mobiliáros. In: LOBO, Jorge. Reforma da lei das Sociedades Anônimas. Rio de Janeiro: Forense, 2002.

CHEFFINS, Brian R. Company Law: Theory, Structure, and Operation. Grã-Bretanha: Clarendon Press - Oxford, 2005.

CHIAVENATO, Idalberto. Administração para Não Administradores. 2. ${ }^{a}$ edição. São Paulo: Manole, 2011.

COASE, Ronald Harry. The Nature of the Firm. In: Economica, New Series, v. 4, n. ${ }^{\circ}$ 16, $\begin{array}{llll}\text { Novembro } & \text { de } & \text { Disponível }\end{array}$ 
<http://www.colorado.edu/ibs/eb/alston/econ4504/readings/The\%20Nature\%20of\%20the $\% 20$ Firm\%20by\%20Coase.pdf>. Acesso em 22.12.2012.

COFFEE JR., John C.. The Rise of Dispersed Ownership : the Roles of Law and the State in the Separation of Ownership and Control. In: Yale Law Journal, v. 111, 2001. Disponível em <http://yalelawjournal.org/images/pdfs/455.pdf>. Acesso em 29.07.2012.

Do Norms Matter?: A Cross-Country Examination of the Private Benefits of Control. In: Columbia Lawand Economics Working Paper, n. ${ }^{\circ}$ 183, 2001. Disponível em <http://papers.ssrn.com/sol3/papers.cfm?abstract_id=257613>. Acesso em 08.06.2014.

COMISSÃO DE VALORES MOBILIÁRIOS. O Mercado de Valores Mobiliários Brasileiro. 2. ${ }^{a}$ edição. Rio de Janeiro: Comissão de Valores Mobiliários, 2013. Disponível em <http://www.cvm.gov.br/port/public/Livro-TOP-2ed.pdf>. Acesso em 30.10.2013.

COMPARATO, Fábio Konder; SALOMÃO FILHO, Calixto. O Poder de Controle na Sociedade Anônimas. 4. ${ }^{\text {a }}$ edição. Rio de Janeiro: Forense, 2005.

Poder de Controle na Sociedade Anônima. In Revista de

Direito Mercantil. São Paulo: Revista dos Tribunais, Ano XII, n. ${ }^{\circ}$ 9, 1973.

Aspectos Jurídicos da Macro-Empresa. São Paulo:

Revista dos Tribunais, 1970.

COSTA, Carlos Celso Orcesi da; Controle Externo nas Companhias. In Revista de Direito Mercantil. São Paulo: Revista dos Tribunais, Ano XX, n. ${ }^{\circ} 44,1981$.

COSTA, Maria Cristina Castilho. Sociologia: Introdução à Ciência da Sociedade. São Paulo: Moderna, 1990.

COZIAN, Maurice; VIANDIER, Alain ; DEBOISSY, Florence. Droit des Sociétés. 14. ${ }^{\text {a }}$ edição. Paris: Litec, 2001. 
DALLARI, Dalmo de Abreu. Elementos de Teria Geral do Estado. 17. edição. São Paulo: Saraiva, 1993.

DAVIS, Gerald F.; THOMPSON, Tracy A.. A Social Movement Perspective on Corporate Control. In: Administrative Science Quarterly, v. 39, n 1, 1994. Disponível em < http://webuser.bus.umich.edu/gfdavis/Papers/A\%20Social\%20Movement.pdf>. Acesso em 09.06.2013.

DELOITE TOUCHE TOHMATSU. Custos para Abertura de Capital no Brasil - Uma Análise sobre as Ofertas entre 2005 e 2011. 2012. Disponível em <http://www.bmfbovespa.com.br/empresas/download/Guia-Custos-para-abertura-decapital-BMFBOVESPA-Deloitte.pdf>. Acesso em 02.09.2012.

DINIZ, Maria Helena. Curso de Direito Civil Brasileiro: Teoria Geral do Direito Civil. 1. ${ }^{\circ}$ vol. 19. ${ }^{\text {a }}$ edição. São Paulo: Saraiva, 2002.

EIZIRIK, Nelson. Propriedade e Controle na Companhia Aberta. In: Questões de Direito Societário e Mercado de Capitais. Rio de Janeiro: Forense, 1987.

et al. Mercado de Capitais - Regime Jurídico. 2. ${ }^{\text {a }}$ edição. Rio de Janeiro: Renovar, 2008.

Propriedade e Controle na Companhia Aberta - Uma Análise Teórica. In Revista de Direito Mercantil. São Paulo: Revista dos Tribunais, Ano XXIII, n. ${ }^{\circ} 54,1984$.

A Lei das S/A Comentada. Vol. I. São Paulo: Quartier Latin, 2011.

ESCOLAR, Rafael Perez. La Sociedad Anónima Europea. Madrid: Montecorvo, 1972.

ETZIONI, Amitai. Análise Comparativa de Organizações Complexas. Rio de Janeiro: Zahar, 1974. 
FAORO, Raymundo. Os Donos do Poder. Vols. 1 e 2. 10. a edição. São Paulo: Globo e Publifolha, 2000.

FEIJÓ, Ricardo. História do Pensamento Econômico. 2. edição. São Paulo: Atlas, 2007.

FERRAZ JUNIOR, Tercio Sampaio. Estudos de Filosofia do Direito: Reflexões sobre o

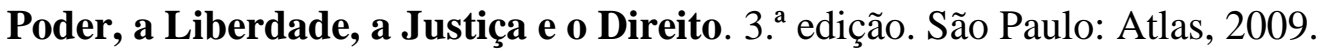

FOLSOM, Ralph H.. European Community Business Law: A Guide to Law and Practice. St. Paul: West Publishing, 1993.

FRANSCISCO, André Marques et al. Análise Juridica das Chamadas Poison Pills Brasileiras. In: PENTEADO, Mauro Rodrigues \& MUNHOZ, Eduardo Secchi. Mercado de Capitais Brasileiro: Doutrina, Cases \& Materials. São Paulo: Quartier Latin, 2012.

FRANCO, Vera Helena de Mello. Direito Empresarial I. 3. ${ }^{a}$ edição. São Paulo: Revista dos Tribunais, 2009.

\& SZTAJN, Rachel. Direito Empresarial II. 2. edição. São Paulo: Revista dos Tribunais, 2009.

FRONTINI, Paulo Salvador. Função Social da Companhia: Limitações do Poder de Controle. In: ADAMEK, Marcelo Vieira Von (coord.). Temas de Direito Societário e Empresarial Contemporâneos. São Paulo: Malheiros, 2011.

FURTADO, Celso. Formação Econômica do Brasil. 27. edição. São Paulo: Companhia Editora Nacional e Publifolha, 2000.

GILSON, Ronald J.; GORDON, Jeffrey N. Controlling Controlling Shareholders. In: University of Pennsylvania Law Review, v. 152, $\mathrm{n}^{\circ}$ 2, 2003. Disponível em <http://papers.ssrn.com/sol3/papers.cfm?abstract_id=417181>. Acesso em 29.07.2012. 
Controlling Shareholders and Corporate Governance:

Complicating the Comparative Taxonomy. In: Harvard Law Review, v. 119, nº 6, 2005.

Disponível em < http://papers.ssrn.com/sol3/papers.cfm?abstract_id=784744>. Acesso em 28.07.2012.

Globalizing Corporate Governance: Convergence of Form or

Function. In: American Journal of Comparative Law, $\mathrm{n}^{\circ}$ 49, 2001. Disponível em <http://papers.ssrn.com/sol3/papers.cfm?abstract_id=229517>. Acesso em 29.07.2012.

; HANSMANN, Henry; PARGENDLER, Mariana. Regulatory

Dualism as a Development Strategy: Corporate Reform in Brazil, the United States and the European Union. In: Standford Law Review, v.63, 2011. Disponível em <http://papers.ssrn.com/sol3/papers.cfm?abstract_id=1541226>. Acesso em 29.07.2012.

GONÇAlVES NETO, Alfredo de Assis. Manual das Companhias ou Sociedades Anônimas. 2. a edição. São Paulo: Revista dos Tribunais, 2010.

GORGA, Érica. Changing the Paradigm of Stock Ownership from Concentrated towards Dispersed Ownership? Evidence from Brazil and Consequences for Emerging Countries. In: Northwestern Journal of International Law \& Business, v.29, 2009. Disponível em < http://papers.ssrn.com/sol3/papers.cfm?abstract_id=1121037>. Acesso em 29.12.2007.

. Direito Societário Atual. Rio de Janeiro: Elsevier, 2013.

Culture and Corporate Law Reform: A Case Study of Brazil. In: University of Pennsylvania Journal of International Economic Law, v. 27, n. 3, 2006. Disponível em <http://papers.ssrn.com/sol3/papers.cfm?abstract_id=999942>. Acesso em 30.06.2014.

GUERREIRO, José Alexandre Tavares. Sociedade Anônima: Poder e Dominação. In Revista de Direito Mercantil. São Paulo: Revista dos Tribunais, Ano XXIII, n. ${ }^{\circ}$ 53, JanMar/1984. 
HAMILTON, Robert W. Cases and Materials on Corporations. 3. ${ }^{a}$ edição. Minnesota: West Publishing, 1986.

HANSMANN, Henry; KRAAKMAN, Renier. The End of History for Corporate Law. In: Georgetown Law Journal, $\mathrm{n}^{\circ}$ 89, 2001. Disponível em: <http://papers.ssrn.com/sol3/papers.cfm?abstract_id=204528>. Acesso em 29.07.2012.

HARDY-HÉMERY, Odette. Le Pouvoir dans L'Enterprise: Actionnaires et Dirigeants dans Les Sociétés du Nord, 1880-1960. In: Revue D'Histoire Moderne et Contemporaine, $\mathrm{n}^{\mathrm{o}}$ 48-4, 2001. Disponível em: < http://www.cairn.info/revue-d-histoire-moderne-etcontemporaine-2001-4-page-77.htm>. Acesso em 09.06.2013.

IAMUNDO, Eduardo. Sociologia e Antropologia do Direito. São Paulo: Saraiva, 2013.

IUDÍCIBUS, Sérgio \& RICARDINO FILHO, Álvaro Augusto. A Primeira Lei das Sociedades Anônimas no Brasil - Lei n. ${ }^{\circ} 1.083$ - 22 de Agosto de 1860. In: Revista Contabilidade \& Finanças. São Paulo: USP, vol. 13, n 29, Maio-Agosto de 2002. Disponível em <http://www.scielo.br/pdf/rcf/v13n29/v13n29a01.pdf> Acesso em 20.01.2013.

JENNINGS, Richard W.; MARSH Jr., Harold; COFFEE Jr, John C.; SELIGMAN, Joel. Federal Securities Laws. 5. ${ }^{a}$ edição. New York: Foundation Press, 2000.

KAPAZ, Emerson. Lei das S.A.: uma Contribuição Decisiva. In: LOBO, Jorge. Reforma da lei das Sociedades Anônimas. Rio de Janeiro: Forense, 2002.

LAMY FILHO, Alfredo. A Reforma da Lei de Sociedades Anônimas. In Revista de Direito Mercantil. São Paulo: Revista dos Tribunais, Ano XI, n. ${ }^{\circ}$ 7, 1972.

; PEDREIRA, José Luiz Bulhões. A Lei das S.A. Rio de Janeiro: Renovar, 1992. 
; PEDREIRA, José Luiz Bulhões. Direito das Companhias.

Vols. I e II. Rio de Janeiro: Forense, 2009.

LA PORTA, Rafael; LOPEZ-DE-SILANES, Florencio; SHLEIFER, Andrei. Corporate Ownership Around the World. In: The Journal of Finance, v. 54, 1999. Disponível em < http://papers.ssrn.com/sol3/papers.cfm?abstract_id=103130>. Acesso em 29.07.2012.

$\&$

VISHNY, Robert W. Legal Determinants of External Finance. In: The Journal of $\begin{array}{lllll}\text { Finance, } & v & & 52, & \text { Disponível em }\end{array}$ <http://papers.ssrn.com/sol3/papers.cfm?abstract_id=8179>. Acesso em 29.07.2012.

LAUTENSCHLEGER JÚNIOR, Nilson. Os Desafios Propostos pela Governança Corporativa ao Direito Empresarial Brasileiro. São Paulo: Malheiros, 2005.

LAZZARESCHI NETO, Alfredo Sérgio. Lei das Sociedades por Ações Anotada. 3. ${ }^{a}$ edição. São Paulo: Saraiva, 2010.

LEÃES, Luiz Gastão Paes de Barros. Pareceres. Vol. I. São Paulo: Singular, 2004.

Poder de Controle. In: Estudos e Pareceres sobre

Sociedades Anônimas. São Paulo: Revista dos Tribunais, 1989.

LOBO, Jorge. Direitos dos Acionistas. Rio de Janeiro: Elsevier, 2011.

LOSANO, Mario Giuseppe. Sistema e Estrutura no Direito: Das Origens à Escola Histórica. Vol. 1. São Paulo: Martins Fontes, 2008.

MACIEL, José Fabio Rodrigues \& AGUIAR, Renan. História do Direito. 6. ${ }^{\text {a }}$ edição. São Paulo: Saraiva, 2013.

MAGANO, Octavio Bueno. Os Grupos de Empresas no Direito do Trabalho. São Paulo: Revista dos Tribunais, 1979. 
MARTIN, Elizabeth A. A Dictionary of Law. 5 edição. Oxford: Oxford, 2002.

MARTINS, Fran. Comentários à Lei das Sociedades Anônimas. 4. ${ }^{\text {a }}$ edição. Rio de Janeiro: Forense, 2010.

MARX, Karl; ENGELS, Friedrich. Manifesto do Partido Comunista. In: Cartas Filosóficas e Outros Escritos. São Paulo: Grijalbo, 1977.

MAYER, Colin. Ownership Matters. Disponível em <ftp://ns1.ystp.ac.ir/YSTP/1/1/ROOT/DATA/PDF/unclassified/OWNERSHIPMATTERS. PDF>. Acesso em 29.07.2014.

MELlO, Celso Antônio Bandeira de. Curso de Direito Administrativo. 6. ${ }^{a}$ edição. São Paulo: Malheiros, 1995.

MICHOUD, Léon. La Théorie de la Personnalité Morale et Son Application au Droit Français. V. 1. Paris: Librarie Générale de Droit e Jurisprudence, 1924.

MIRANDA, Pontes de. Tratado de Direito Privado. Tomo 2. Campinas: Bookseller, 2000.

MOGOROVICH, Sergio. La Società per Azioni. Roma: Buffetti, 2003.

MORENO, Fernando Sainz. Conceptos Jurídicos, Interpretación y Discricionariedad Administrativa. 4. ${ }^{a}$ edição. Madri: Civitas, 1976.

MUNHOZ, Eduardo Secchi. Desafios do Direito Societário Brasileiro na Disciplina da Companhia Aberta: Avaliação dos Sistemas de Controle Diluído e Concentrado. In: CASTRO, Rodrigo R. Monteiro de; ARAGÃO, Leandro Santos de. Direito Societário Desafios Atuais. São Paulo: Quartier Latin, 2009.

Transferência de Controle nos Sistemas de Controle Concentrado e de Capital Disperso: Eficiências e Ineficiências. In: ADAMEK, Marcelo 
Vieira Von. Temas de Direito Societário e Empresarial Contemporâneos. São Paulo: Malheiros, 2011.

. Empresa Contemporânea e Direito Societário - Poder de

Controle e Grupos de Sociedades. São Paulo: Juarez de Oliveira, 2002.

Aquisição de Controle na Sociedade Anônima. São Paulo:

Saraiva, 2013.

. Quem Deve Comandar a Companhia? Alocação do Poder

Empresarial: Sistema de Freios e Contrapesos. In: KUYVEN, Luiz Fernando Martins.

Temas Essenciais de Direito Empresarial. São Paulo: Saraiva, 2012.

OIOLI, Erik Frederico. Oferta Pública de Aquisição do Controle de Companhias Abertas. 1. ${ }^{a}$ edição. São Paulo: Quartier Latin, 2010.

PARKINSON, John E. Corporate Power and Responsability - Issues in the Theory of Company Law. Nova Iorque: Oxford University Press, 2002.

PARENTE, Norma. Principais Inovações Introduzidas pela Lei n. ${ }^{\circ} 10.303$, de 31 de Outubro de 2001, à Lei de Sociedades por Ações. In: LOBO, Jorge. Reforma da lei das Sociedades Anônimas. Rio de Janeiro: Forense, 2002.

PARGENDLER, Mariana. Evolução do Direito Societário: Lições do Brasil. São Paulo: Saraiva, 2013.

PEDREIRA, José Luiz Bulhões. Acordo de Acionistas sobre Controle de Grupo de Sociedades. In: Revista de Direito Bancário, do Mercado de Capitais e da Arbitragem. São Paulo: Revista dos Tribunais, Ano 5, n. ${ }^{\circ}$ 15, Jan-Mar de 2002.

PENTEADO, Mauro Rodrigues. Aumentos de Capital das Sociedades Anônimas. São Paulo: Saraiva, 1988. 
. Dissolução e Liquidação de Sociedades. Brasília:

Brasília Jurídica, 1995.

Apontamentos sobre a Alienação do Controle de

Companhias Abertas. In Revista de Direito Mercantil. São Paulo: Revista dos Tribunais, Ano XXVIII, n. ${ }^{\circ}$ 76, Dez - 1989.

; Munhoz, Eduardo Secchi. Mercado de Capitais

Brasileiro. São Paulo: Quartie Latin, 2012.

PEREIRA, Guilherme Döring Cunha. Alienação do Poder de Controle Acionário. São Paulo: Saraiva, 1995.

PEREIRA, Luiz Carlos Bresser. Economia Brasileira. 7. edição. São Paulo: Brasiliense, 1988.

PONTES, Aloysio Lopes. Sociedades Anônimas. Vol. II. 4. a edição. Rio de Janeiro: Revista Forense, 1957.

PRADO, Roberta Nioac. Desconcentração do Poder de Controle e Poison Pills: Evolução no Mercado de Capitais Brasileiro. In: CASTRO, Rodrigo R. Monteiro de; AZEVEDO, Luís André N. de Moura. Poder de Controle e Outros Temas de Direito Societário e Mercado de Capitais. São Paulo: Quartier Latin, 2010.

PROCIANOY, Jairo Laser; VERDI, Rodrigo S. Adesão aos Novos Mercados da BOVESPA: Novo Mercado, Nível 1 e Nível 2 - Determintes e Consequências. In: Revista Brasileira de Finanças, v. 7, n. ${ }^{\circ}$ 1, 2009. Disponível em $<$ http://bibliotecadigital.fgv.br/ojs/index.php/rbfin/article/viewFile/1429/799>. Acesso em 30.06.2014.

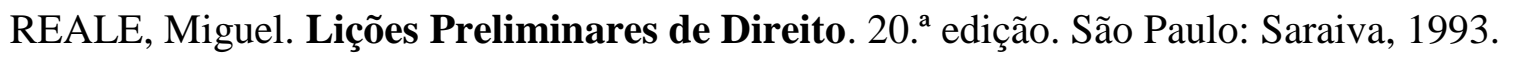

ROBINS, Nick. A Corporação que Mudou o Mundo. Rio de Janeiro: Bertrand Brasi DIFEL, 2012. 
ROCHA, José Manuel de Sacadura. Sociologia Jurídica. 3. edição. Rio de Janeiro: Elsevier, 2013.

ROE, Mark J.. Capital Markets and Financial Politics: Preferences and Institutions. In: Oxford Handbook on Capitalism, 2011. Disponível em: <http://papers.ssrn.com/sol3/papers.cfm?abstract_id=1723331〉. Acesso em 20.05.2014.

\& BEBCHUK, Lucian. A Theory of Path Dependency in Corporate Governance and Ownership. In: Standford Law Review, v. 52, 1999. Disponível em: <http://papers.ssrn.com/sol3/papers.cfm?abstract_id=202748>. Acesso em 29.07.2012.

SAlOMÃO FILHO, Calixto. O Novo Direito Societário. 3. ${ }^{a}$ edição. São Paulo: Malheiros, 2006.

SANTOS, Anthonny Dias dos. Transações Entre Partes Relacionadas e Abuso do Poder de Controle. São Paulo: Almedina, 2011.

SANTOS, Edilene Santana; CIA, Joanília Neide Sales; CIA, Josilmar Cordenonssi. US GAAP x Normas Brasileiras: Mensuração do Impacto das Diferenças de Normas no Lucro Duplamente Reportado pelas Empresas Brasileiras Emissoras de ADRS na NYSE. In: Revista de Administração Mackenzie, v. 12. n. ${ }^{\circ}$ 1, São Paulo, 2011. Disponível em <http://www.scielo.br/scielo.php?pid=S1678-69712011000100004\&script=sci_arttext $>$ Acesso em 24.02.2013.

SCHMIDT, Dominique. Les Conflits D'Intérêts dans la Société Anonyme. Version nouvelle. Paris: Joly, 2004.

SCHMITTHOFF, Clive M. European CompanyLaw Texts. Nova Iorque: Matthew Bender, 1974.

SCORGNAMIGLIO, Giuliana. Codice delle Società. Bologna: Zanichelli, 2004. 
SILVEIRA, Alexandre Di Miceli da; PEROBELLI, Fernanda Finotti Cordeiro; BARROS, Lucas Ayres Barreira de Campos. Governança Corporativa e os Determinantes da Estrutura de Capital: Evidências Empíricas no Brasil. In: Revista de Administração Contemporânea, $\quad$ v. $12, \quad 2008$ Disponível em < http://200.144.190.38/bitstream/handle/2012.1/6257/art_SILVEIRA_Governanca_Corpora tiva_e_os_determinantes_da_estrutura_2008.pdf?sequence=1 >. Acesso em 29.07.2012.

; SAITO, Richard. Governança Corporativa:

Custos de Agência e Estrutura de Propriedade. In: Revista de Administração de Empresas, $\quad$ v. $48, \quad$ n. ${ }^{\circ} \quad 2, \quad 2008 . \quad$ Disponível em <http://www.scielo.br/pdf/rae/v48n2/v48n2a07.pdf>. Acesso em 30.06.2014.

SROUR, Robert Henry. Poder, Cultura e Ética nas Organizações. 3. a edição. Rio de Janeiro: Elsevier, 2012.

SZTAJN, Rachel. Teoria Jurídica da Empresa. 2. ${ }^{a}$ edição. São Paulo: Atlas, 2010. . Sistema Financeiro Entre Estabilidade e Risco. Rio de Janeiro: Elsevier, 2011.

TAVARES, André Ramos. Direito Constitucional Econômico. São Paulo: Método, 2003.

TEIXEIRA, Egberto Lacerda; GUERREIRO, José Alexandre Tavares. Das Sociedades Anônimas no Direito Brasileiro. Vol. 1. São Paulo: Bushatsky, 1979.

TOMAZETTE, Marlon. Direito Societário. São Paulo: Juarez de Oliveira, 2003.

TRUBEK, David M.; VIEIRA, Jorge Hilário Gouvêa; SÁ, Paulo Fernandes de. Direito, Planejamento e Desenvolvimento do Mercado de Capitais Brasileiro 1965-1970. 2. ${ }^{\mathrm{a}}$ edição. São Paulo: Saraiva, 2011.

TUNC, André. Le Droit Américain Des Sociétés Anonymes. Paris: Economica, 1985. 
VALVERDE, Trajano de Miranda. Sociedades por Ações. Vol. II. 2. a edição. Rio de Janeiro: Revista Forense, 1953.

VERÇOSA, Haroldo Malheiros Duclerc. Curso de Direito Comercial. Vol. 1. 2. edição. São Paulo: Malheiros, 2008. . Curso de Direito Comercial. Vol. 2. 2. ${ }^{\mathrm{a}}$ edição.

São Paulo: Malheiros, 2010. . Curso de Direito Comercial. Vol. 3. São Paulo: Malheiros, 2008.

VIDIGAL, Geraldo de Camargo. Fundamentos do Direito Financeiro. São Paulo: Revista dos Tribunais, 1973.

VILANOVA, Lourival. As Estruturas Lógicas e o Sistema de Direito Positivo. 4. ${ }^{\text {a }}$ edição. São Paulo: Noeses, 2010.

WALD, Arnoldo. O Governo das Empresas. In: Revista de Direito Bancário, do Mercado de Capitais e da Arbitragem. São Paulo: Revista dos Tribunais, Ano 5, n. ${ }^{\circ}$ 15, Jan-Mar de 2002.

O Acordo de Acionistas e o Poder de Controle do Acionista Majoritário. In Revista de Direito Mercantil. São Paulo: Malheiros, Ano XXXVI, n. ${ }^{\circ}$ 110, Jun/1998.

YAZBEK, Otavio. Regulação do Mercado Financeiro e de Capitais. 2. a edição. Rio de Janeiro: Elsevier, 2009. 